Historic, Archive Document

Do not assume content reflects current scientific knowledge, policies, or practices. 



\section{KING ALFRED}

THE GIANT NARCISSUS

4 INCHES ACROSS I $1 / 2$ INCH TRUMPET

754 EACH, \$8 PER DOZ. $\$ 65$ PER 100 SEE PAGE 17

\section{Stumpp \& Walter 6 $30 \& 32$ BARCLAY ST. NEW YORK}




\section{Sixteenth Anniversary Announcement}

E signalize the Sixteenth Anniversary of the estabT A lishment of our business by removing to larger premises, giving us twice the space now crowded in filling the orders of those who have found it worth while to deal with us.

Our address after September first will be 30 and 32 Barclay Street, where we will occupy one of the largest and best-equipped seedstores and warehouses in New York City.

This Fall Catalogue, which principally features Bulbs for Fall Planting, has been compiled with every regard for the best and most modern varieties. Our resolution to change the order in which Bulbs are offered is due to the recent popularity given the Darwin Tulips, making Tulips the most important of Spring-flowering Bulbs.

One of our firm spent three months in the bulb-growing sections of Holland and the Continent inspecting our cultures of Bulbs during the blooming period, and our patrons may be assured that the quality of the stock we offer this year cannot be excelled.

Last year our importations included 1,821 cases, with $3,175,615$ bulbs, making us the largest bulb importers in New York.

We ask our friends to visit our New Establishment after September 1, and we thank them for the earnest support which has made this new venture possible, while extending our assurance that our efforts will always be made to better serve those who have made our success.

JULIAN H. WALTER, President GEORGE G. STUMPP, Treasurer WILLIAM A. SPERLING, Secretary

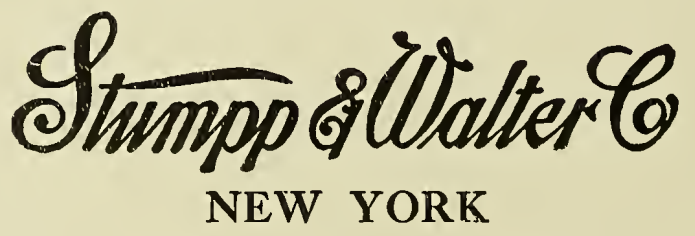




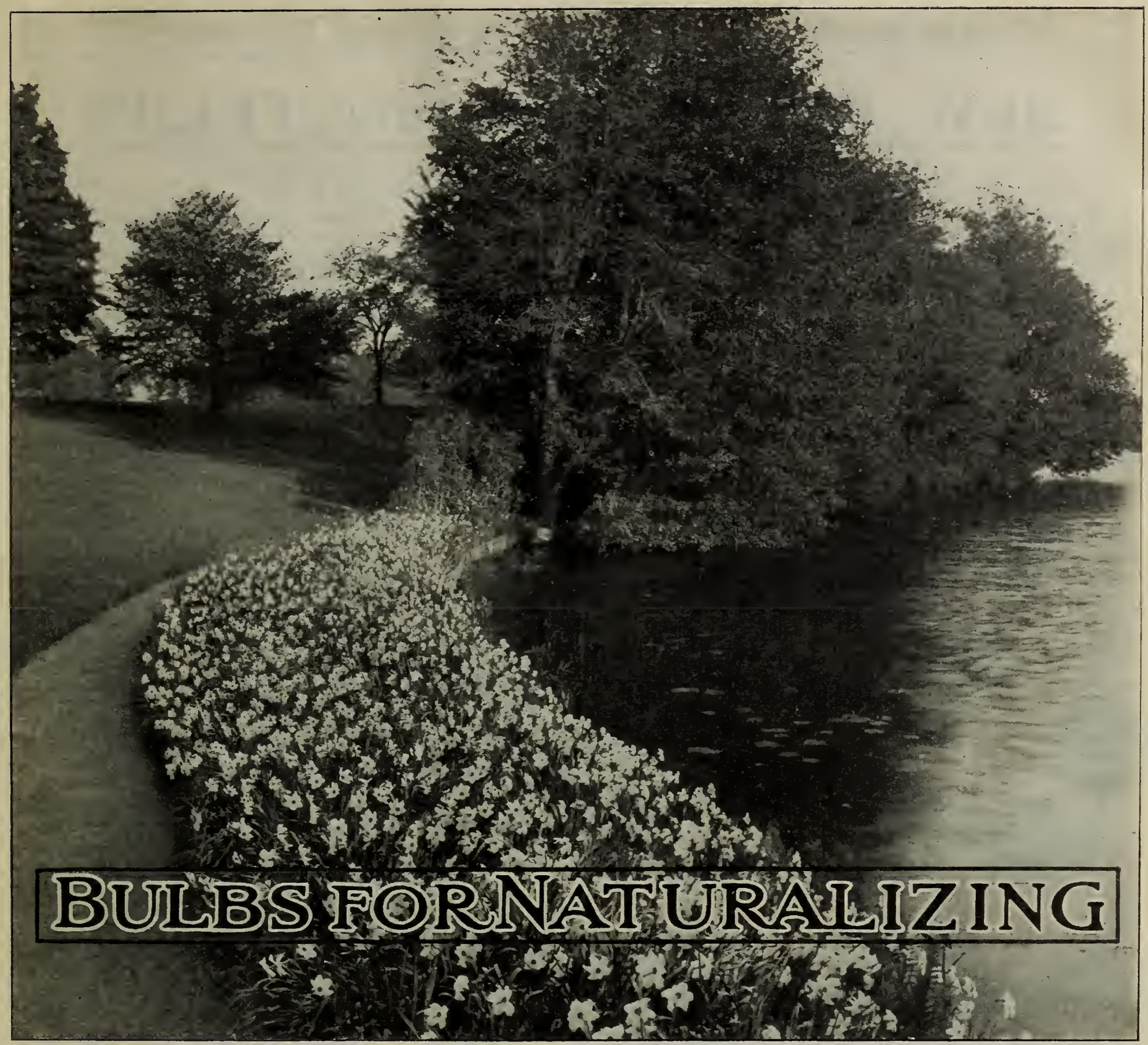

The tendency to plant bulbs along banks of streams, in the grass and along woodland driveways, has induced us to mention a few of the bulbs which may be had in quantities at nominal prices. Narcissus poeticus is frequently used in large quantities for this splendid purpose. FOR DESCRIPTIONS, SEE BODY OF CATALOGUE

\begin{tabular}{|c|c|c|c|c|c|c|}
\hline Camassia esculenta (Indian Quamash). & & $\begin{array}{l}\mathrm{I}, 000 \\
\$ 100\end{array}$ & Narcissus Barrii conspicuus & & & $\begin{array}{c}\mathrm{I}, 000 \\
\$ 1200\end{array}$ \\
\hline Chionodoxa Luciliæ (Glory-of-the-Snow). & & Iо $\mathrm{c}$ & Narcissus, Golden Spur. First size. & & oo & I 500 \\
\hline Crocus. Mixed sorts.. & 60 & & Narcissus Leedsii, Mrs. Langtry. & I & 50 & I0 oo \\
\hline Eranthis hyemalis (Winter Aconite). & I 50 & Io 0 & Narcissus poeticus (Poet's Narcissus). & I & oo & 750 \\
\hline Erythronium (Dog's-tooth Violet).. & I 00 & 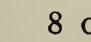 & Narcissus, Victoria. First size....... & & oo & I5 00 \\
\hline Fritillaria Meleagris (Guinea Hen Flower) & I 50 & I2 $\mathrm{c}$ & Narcissus, Von Sion, Double. First size. & & $\infty$ & \\
\hline Grape Hyacinth. White and Blue. & I 00 & 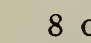 & Narcissus, Double Varieties. Mixed. & & 25 & Io oo \\
\hline Iris Anglica (English Iris). Mixed. & I 25 & IO $\mathrm{c}$ & Narcissus, Single Giant Trumpets. Mixed. & & 50 & \\
\hline Iris Hispanica (Spanish Iris). Mixed. & 75 & $5 \mathrm{c}$ & Ornithogalum umbellatum. & I & oo & 8 oo \\
\hline Leucojum vernum (Spring Snowflake). & I 50 & I2 0 & lata. White or b & & 25 & Io 00 \\
\hline in Bellflower Lily). & oo & 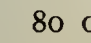 & Blue (English Bluebell). & & $\infty$ & \\
\hline k's Ca! & o oc & $90 \mathrm{c}-2 \cdot \mathrm{c}$ & le Elwesii Giant. & & oo & \\
\hline Lilium tigrinum (Tiger Lily).......... & & $75 \mathrm{c}$ & Trillium grandiflorum (American Wood Lily).. & & $\infty$ & 4500 \\
\hline
\end{tabular}




\section{NEW GIANT DARWIN TULIPS}

For the herbaceous border, massed in clumps along the edge of shrubbery, or as cut-flowers for vases, these are conceded to be the superior of all the Tulips

The maddening craze for the Darwin Tulip is not due to fad or popular fancy, but rather an awakened sense of appreciation of their majestic beauty. The rich, bright colors of the blooms, their somber tones, their many pale and more lovely colors, produced on strong, gigantic stems from 2 to 3 feet, all vie with one another and capture even the casual observer of spring-flowering bulbs. Once grown, the amateur becomes interested and soon becomes a fancier with a hoard of varieties, excusably jealous of every one he grows.

For the borders among other hardy flowers, in formal gardens in conjunction with Single Early Tulips, for isolated groupings against a background of shrubs, or for combinations of delicate colors for effects of contrast in the flower-garden, the Darwins are without a peer.

Whether seen under the midday sun, when their blooms are wide open, or at the close of day when the flowers close, showing their charming shapes and the softness of their wax-like blooms, their beauty is truly inspiring.

They range in color from the daintiest pink, rose, salmon, red, etc., to deep, rich crimson; from lavender through mauve and light blue to violet-purple and black. There are a few good whites, but no clear yellow, and where this color is desired a selection should be made from the Cottage Tulips listed on page 7. All buff and bronze shades frequently classed as Darwins are Breeders. (See page 5.)

CULTURE. - Bulbs should be planted 5 to 6 inches deep and not less than 5 inches apart. Sand to the depth of $1 / 2$ inch at the base of the bulbs will amply repay the trouble by the provision for drainage during wet weather. For forcing, bulbs should be planted as soon as received, and the flowers appear to better advantage if pots a trifle deeper than the ordinary bulb-pans are used.

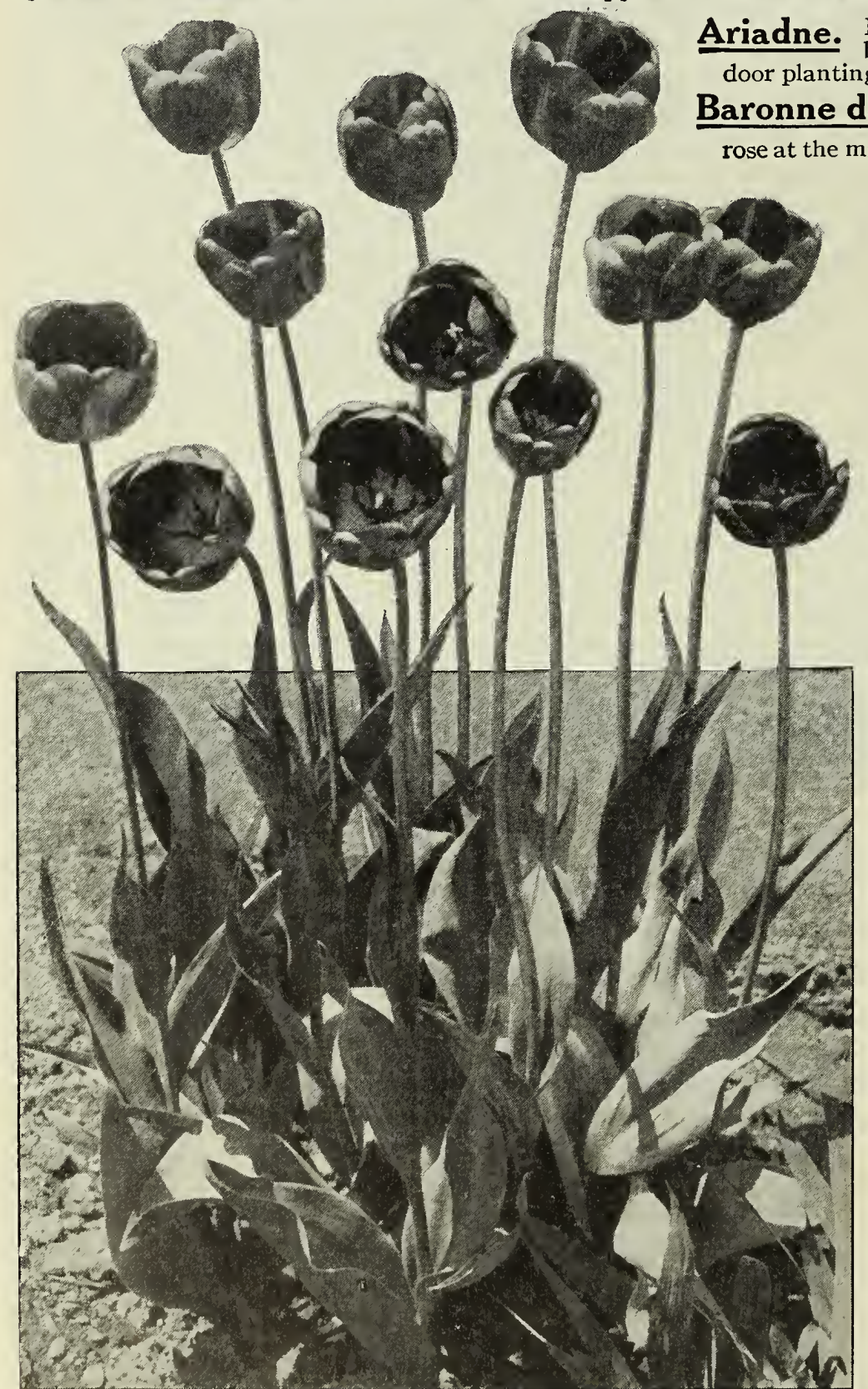

An imposing clump of Farncombe Sanders, showing magnificent stems
Bright rosy crimson, shaded scarlet, with blue Doz. base; large flower of great substance; for out-

door planting or late forcing. Height 28 inches........\$0 $60 \quad \$ 450 \quad \$ 4000$

Baronne de la Tonnaye. A long and beautiful rose at the midrib, toning off to soft pink at the edges; base white, tinged blue. Excellent for early March forcing and just as fine for outdoor beds, where it keeps up a splendid show for a long time. Height 26 inches.

Carl Becker. Pale rosy violet, center Carl Becker. flushed salmon. An exceedingly pleasing variety for border planting, and beautiful when forced, but paler in color. Height 30 inches.......

Centenaire. Rich violet, with a slight Centenaire. rose tone, center large blue. A magnificent Tulip for the border or March forcing. 'Flowers extra large. Height $\mathbf{3 2}^{2}$ inches...........

Clara Butt. Clear pink flushed salClara Butt. mon-rose; good-sized flower of very handsome shape. The finest Darwin of its color. Exquisitely beautiful out-of-doors, and one of the best for pots if not forced too early. Height 21 inches................

Dream. Large flowers, perfect in form, Dream. on tall, strong stems; color rosy lilac and mauve, with claret-purple
interior, a most exquisite combination. Height 24 inches. .

Edmee (Beauty). Vivid shade of cherryflower of very great beauty. Handsome in the border and fine for March forcing. Height 25 inches .................

Electra. Rosy lilac, broadly margined flower; distinct and beautiful, and contrast well with darker-shaded Tulips. Height 26 inches. .

Europe. Deep, fiery crimson, white tiful sight than a bed of this variety. Stems are of medium length; the flowers large and erect, with white base contrasting well when flower is fully open. Height 22 inches................

Farncombe Sanders. Brilliant, red; flowers large, borne on long, stiff stems; base shaded white. A giant among large-flowering varieties. Conceded to be the best variety in its color for outdoor planting or March forcing, and makes a glorious show in the garden or greenhouse. Height 24 inches.........
50 350

450 4000

500 4500 


\section{NEW GIANT DARWIN TULIPS, continued}

Flamingo. An even tone of pure shell- Doz. Ioo $\mathrm{r}, 000$ refined form pink; flower pointed and of unsurpassed beauty for border planting.

Height 28 inches.................. \$o $85 \$ \$ 600 \quad \$ 60$ oo Glow. Bright vermilion-scarlet, white base flowers of distinct shape. An excellent scarlet for bedding and forcing. Height 20 in..

Grand Maitre. A distinct dark violet, sheen; large flower of refined form, borne on a strong, stiff stem. A splendid Darwin for contrasting. Height 24 inches ........

Gretchen (Margaret). A very large, globular flower of soft blushrose. Award of merit R. H. S. Excellent for forcing. Height 22 inches ..............

Gryphus. Brilliant, dark violet-purple blue; large flower, beautifully formed, on long, graceful stem. Quite the best in this color and excellent for contrasting with lighter colors. Height 26 inches. 85 cts. per doz., $\$ 6$ per $100, \$ 55$ per 1,000 .

Harry Veitch. A rich blood-red, very with blue base; large, bold flower on long stem. Early sort for forcing. Height 28 in. 50c. per doz., $\$ 3.50$ per $100, \$ 30$ per 1,000 .

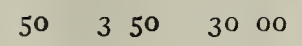

$60 \quad 450 \quad 4000$

$30 \quad 2$ OO I5 00

Isis. Fiery crimson-scarlet, with blue base; Doz. IOO

The most brilliant of its color, and decidedly the best. Height 26 inches............ \$o $75 \quad \$_{5} \quad 50 \quad \$_{52}$ co

King Harold. Intense ruby-crimson, tall and of fine center rich black; very tall and of fine form; new and stately variety; very distinct. Height 24 inches..

$50 \quad 3 \quad 50 \quad 3000$

Lantern. Pale silvery lilac, passing into base; medium-sized fide clear lilac with white Height 20 inches ....................

La Tristesse. Deep, slaty blue, with white base, very distinct in color; medium-sized flower. Striking contrast may be had by planting this variety in combination with the pale yellow sorts of the Cottage Tulips. Height 26 inches.....

La Tulipe Noire (The Black Tulip). - Deep maroon-black, having a velvety sheen in the sunlight; large flower of fine form. Height 25 inches......

Leonardo da Vinci. Brilliant masoft-petaled flower of large size and fine form. Height 24 inches... . Loveliness. A finely flower of rosy carmine; about 20 inches high, of sturdy habit. Excellent for any position outside. Madame Krelage. Bright lilac-rose, margined pale silvery rose; flower long and of excellent form. Excellent for borders or pots. Height 28 inches.................

Massachusetts. Beautiful pink, center; large flowers of beautiful color and form. One of the best of its color for either border or beds. Height 24 inches........

May Queen. Pale lilac-rose, center delilong, large flower. One of the best of its color. Excellent for borders or among shrubs. Height 26 inches.............

Nauticas. Dark rose, center clear violet, auticas. shaded bronze; large flower. Excellent for outdoors and early or late forcing. Height 30 inches..............

Ouida. Bright crimson-scarlet, center blue. for its keeping qualities.

Palissa. Rich, bright violet, base white; a alissa. very handsome variety that should be in every collection. Height 24 inches.

Philippe de Commines. A grand dark, polished mahogany color, with a purple base. Height 24 inches................

Pride of Haarlem. Magnificently immense size; brilliant, deep salmon-rose, shaded scarlet, light blue base. This variety, perhaps the most widely known for its stately habit and glorious color, is unsurpassed for border or early forcing. Height 26 inches. .

Princess Juliana. Orange-scarlet, with blue base; the color is of great brilliance when open, contrasting with the blue of the base. Height 24 inches...

Prof. Rauwenhoff. Deep cherry-rose

Prof. Rauwenhoff. with salmon glow inside; enormous flower of great substance on a strong stem. Superb for borders or among shrubbery and one of the finest forcing varieties. Height 28 inches. 


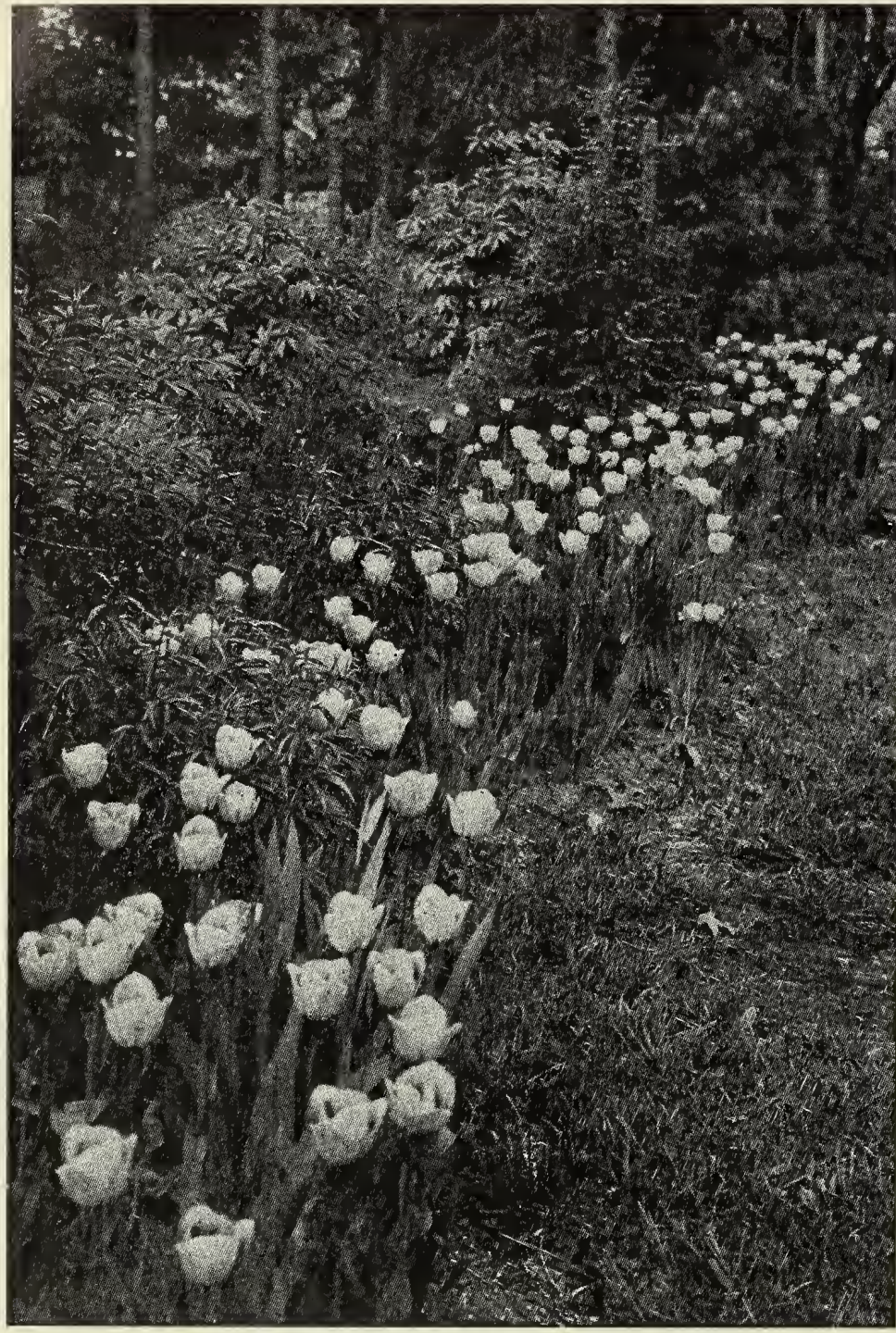

Rev. H. Ewbank Tulip as a border for shrubs

\section{DARWIN TULIPS, continued}

Psyche. Old-rose, edged white, inside Doz. Ioo $\mathrm{I}, 000$ lighter rose, base blue. A very grand variety for February forcing. Height 26 inches...................... \$o $85 \$ \$ 6 \quad \$ 00$ co

Queen of the Roses. A very charmbrilliant crimson-rose. Height 22 inches...

Rev. H. Ewbank. Vivid heliotrope-lilac; lent for forcing; best in its color. Height 22 inches

The Sultan. Rich maroon-black with blue base; small flower of fine form; a good Tulip among the darker sorts to plant with yellow Cottage Tulips. Excellent for forcing. Height 25 inches ......

White Queen (La Candeur). Almost a Wure white when mature; faintly blush-rose when first open. Excellent for borders and pots and fine for contrasts. Height 24 inches..............

William Pitt. Very dark crimson, with purplish bloom on the outer petals; an exact counterpart in color to Coleur Cardinal of the early Tulips, with the added attractiveness of greater size and length of stem. Height 24 inches.......

Zulu. Deep, velvety purple-black; large form. Fine for border or forcing. Height 27 inches.....................

Superb Prize Mixture. The revival of the craze for these splendid Tulips has brought out a great many varieties too numerous for listing, except those considered the best. In addition to the varieties listed above, our mixture contains an equal proportion of many others. Brilliant effect may be obtained by the planting of this mixture of choice named sorts ....................

$\begin{array}{lllll}35 & 2 & 25 & 20 & 00\end{array}$

\section{Collection of New Giant Darwins Prepaid anywhere in the United States}

One bulb each of 40 varieties, 40 bulbs..........\$2 50 Five bulbs each of 40 varieties, 200 bulbs............ I0 00

\section{Color Scheme Suggestions}

It is quite beyond one to fully describe the possibilities that may be attained in color effects by the planting in clumps of twenty-five bulbs each in borders of Darwin, Cottage and Breeder Tulips. There is the purple and violet border shading from the deepest plum to the delicate silvery lilac and pale white, which may be accomplished by planting in the following order:

Leonardo da Vinci, Turenne, Chestnut, Philippe de Commines, Cardinal Manning, Duke of Edinburg, Fairy, Dom Pedro, La Tristesse, Palissa, Rev. H. Ewbank, Dream, Grand Maitre, Lantern and White Queen.

This may be continued into the flesh-pinks, roses, rosy-scarlets and crimsons-with such varieties as Margaret, Flamingo, Clara Butt, Edmee, May Queen, Massachusetts, Loveliness, Ariadne, Glow, King Harold, Farncombe Sanders and William Pitt, merging into the deep maroon varieties.

Velvet King, Zulu and Sultan, and afterwards shading off through bronzy orange and bronze to the pure yellows, primroses and creams in the following order: Prince of Orange, Jaune d'Oeuf, Bronze Queen, Bouton d'Or, Inglescomb Yellow, Ellen Willmott and Vitellina.

For description of above-named varieties, see pages $3,4,5,6$ and 7 . 


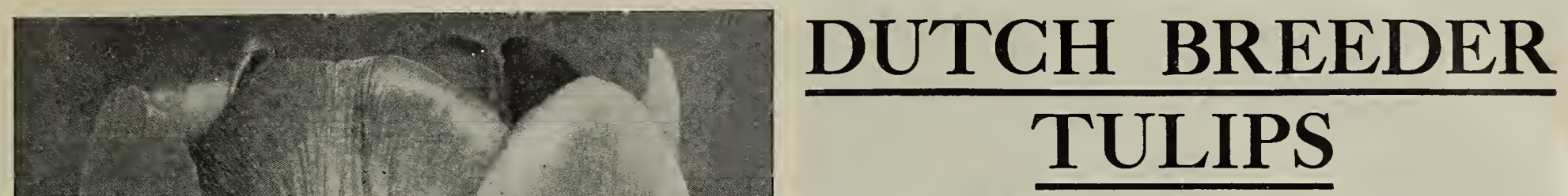

Breeder Tulips are very similar in habit to the Darwins and flower at the same time. Their chief characteristic is their immense blooms, borne on strong, stiff stems, many of them longer than the most gigantic Darwins. The revival of the taste for art colors has made these Tulips, at one time very popular in England, strong favorites with American enthusiasts, who find in their bronze, buff and brown shades excellent material for contrasting with the light and bright colors of the Darwins.

Bronze Queen. Soft buff, inside tinged golden bronze; large 24 inches. $60 \mathrm{cts}$. per doz., $\$ 4.50$ per I00, $\$ 40$ per 1,000 . Height Cardinal Manning. Dull wine-red, flushed rosy bronze; 50 cts. per doz., $\$ 4$ per I0o, $\$ 35$ per I, 000. Chestnut (La Nuit). Very dark brown, almost a black; very Cottage Tulips. Height 24 inches. $50 \mathrm{cts}$. per doz., $\$ 3.50$ per roo, $\$ 30$ per 1,000 .

Dom Pedro. A unique shade of coffee-brown, shaded maroon, inside rich mahogany; large flower; very fragrant. Height $2 \mathrm{r}$ inches. \$1.75 per doz., \$12 per roo.

Duke of Edinburgh. Deep, rich plum-color; borne on strong, stout stems. Height 24 inches. \$I.50

2.3. $\begin{gathered}\text { per doz., } \$ \text { Io per roo. } \\ \text { Fairy. Reddish mahogany, with }\end{gathered}$ airy. bronze shading; an extralarge flower of artistic character. Splendid in borders or for late forcing. Height 24 inches. $75 \mathrm{cts}$. per doz., $\$ 5.50$ per roo, $\$ 50$ per I,000. General Ney. Dull old-gold, with flower. Height 25 inches. 50 cts. per doz., $\$ 3.50$ per $100, \$ 30$ per 1,000 .

Godet Parfait. Bright violet, with white Gode; very large flower of striking color. Fine for the border. Height 30 inches. 50 cts. per doz., $\$ 4$ per I00, $\$ 35$ per I,000. Jaune d'Oeuf. Ruddy apricot, inside soft yellow with black base and anthers; very striking variety. Height $2 \mathrm{I}$ inches. $50 \mathrm{cts}$. per doz., $\$ 4$ per roo, $\$ 35$ per 1,000 .

La Singuliere. Opening silvery white, heavily flushed La Singuliere. at the margin with dark crimson. Quite a distinct sort among this excellent. class of Tulips and produces very large flowers. Height 25 inches. $60 \mathrm{cts}$. per doz., $\$ 4.5^{\circ}$ per I00, $\$ 40$ per $\mathrm{r}, 000$.

Medea. Salmon-carmine, a color that keeps well; one of the Medea. largest Tulips known. Height 27 inches. 50 cts. per doz., $\$ 4$ per roo, $\$ 35$ per r,000.

Prince of Orange. Orange-scarlet, edged lighter red; large, der and good for forcing. Height 24 inches. $60 \mathrm{cts}$. per doz., $\$ 4.50$ per I00, $\$ 40$ per $\mathrm{r}, 000$.

\section{PARROT TULIPS}

\section{Three-year-old Flowering Bulbs}

These Tulips belong to the late-flowering garden varieties, which are generally in full bloom during the latter part of May. Have immense, picturesque forms and brilliant colors. The petals have peculiarly feathered and fringed edges, and the shape of the flower, especially before it opens, resembles the neck of a parrot.

\section{0 ets. per doz., $\$ 3$ per 100}

Admiral de Constantinople. Large red flowers, tipped with orange. Cramoisi Brillant. Deep carmine; very handsome.

Lutea major. Large; bright yellow.

Markgrave of Baden. Yellow, striped with scarlet and green.

Perfecta. Yellow and red striped.

Rubra major. Blood-red; handsome.

Mixed. 40 cts. per doz., $\$ 2.50$ per 100.

A collection of one each of the above-named 6 sorts for 50c., postpaid.
Turenne, Purplish brown, with a broad margin of soft yellow; $\$$ r.50 per doz., \$ro per roo.

Velvet King. Dark, glossy purple-maroon, with a white base marked blue; an enormous flower having an cent Tulip for the border or shrubbery and forms an effective contrast when planted with the light-colored Tulips. Height 28 inches. $\$ 1.75$ per doz., $\$ 12$ per 100 .

Dutch Breeder Mixture. A choice mixture of many vaMagnificent combinations of colors and shades from beautifully flushed white to deep wine-red, art bronze and darkest maroon. 30 cts. per doz., $\$ 2$ per 100, $\$ 18$ per r, 000 .

Bizarres, Mixed.

MIXTURES OF TYPES

Bybloems, Rose.

Doz. $\quad$ I00 $\quad$ I,000

Bybloems, violet...................... $30 \quad 2 \quad 25$ I 15 o0 


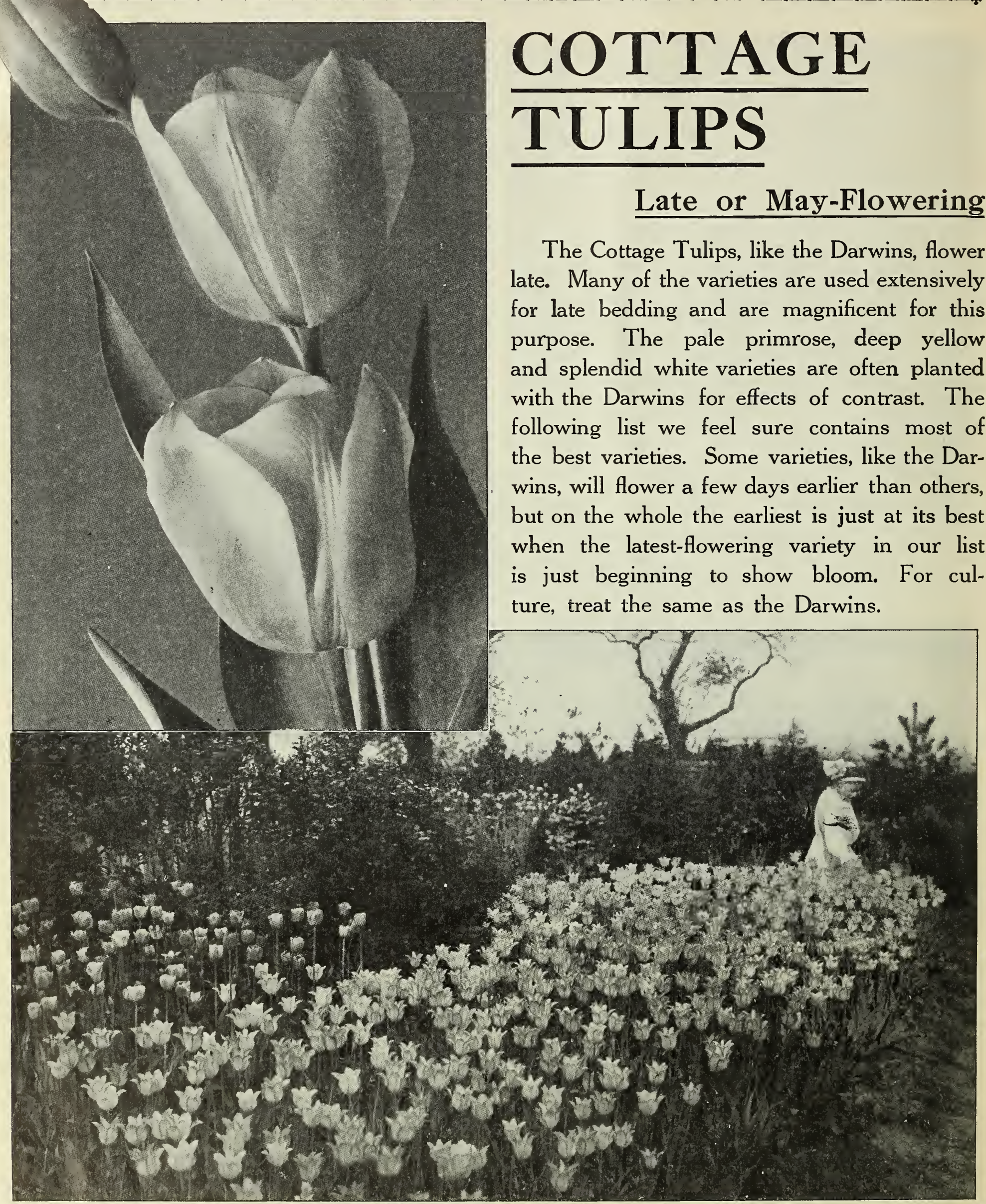

Bed of Picotee Tulips, and Blooms of Inglescombe Pink (Salmon Queen) 


\section{COTTAGE TULIPS}

Bouton d'Or (Golden Beauty). A very stately variety of instance. Excellent for bedding or cutting. Height I8 inches. 30 cts. per doz., \$I.75 per IOO, \$I 5 per I,000.

Caledonia. Orange-scarlet with yellow base. Its dwarf habit desirable variety for beds. Height I 8 inches. $35 \mathrm{cts}$. per doz., $\$ 2.50$ per I00, \$18 per I, 000.

Doris. Soft rosy lilac, flushed silvery gray, blue base; large, eggshaped flowers, borne on strong stems. Height 24 inches. 50 cts. per doz., $\$ 3.50$ per I00, $\$ 32.50$ per I,000.

Elegans. Brilliant crimson with yellow center; long flower with very good for late forcing. Height $\mathrm{I}_{5}$ inches. $40 \mathrm{cts}$. per doz., $\$ 3$ per 100, \$27 per $x, 000$.

Elegans alba (White Crown). Creamy white, petals elegantly rose which reflexed, with a narrow margin of bright carmineborders or late forcing. Height 20 inches. 50 cts. per doz., $\$ 3.25$ per I00, $\$ 30$ per I,000.

Fairy Queen. Beautiful soft rosy lilac, outer petals broadly be included in every collection on account of its unique and lovely color. Height 20 inches. 50 cts. per doz., $\$ 3$ per I 00, $\$ 25$ per $\mathrm{I}, 000$.

Fulgens. Bright crimson with white center; flowers are long and uens. reflexed. Very showy for borders. Height 22 inches. 50 cts. per doz., \$3 per I00, \$25 per I,000.

Gesneriana aurantiaca maculata (Orange Beauty). red; enormous flowers, borne on strong, stiff stems. Height I8 inches. 50 cts. per doz., $\$ 3$ per I00, $\$ 25$ per I,000.

Gesneriana lutea. One of the best of the well-known Gesneriana family. A bedder of unsurpassed qualities, with perfect-shaped flowers of purest golden yellow, on strong stems holding the flowers perfectly erect. Height 24 inches. 50 cts. per doz., \$3 per roo, \$25 per I,000.

Gesneriana spathulata or major. The bea $u$ t if $u$ brilliant scarlet, with a bluish black center, on tall stems. Height, I 8 inches. $30 \mathrm{cts}$. per doz., \$I.75 per IOO, \$I 5 per I,000.

Golden Crown. Pale yellow edged crimson-red; as the for borders or late forcing. Height I6 inches. 25 cts. per doz., \$I.50 per I00, \$I2.50 per I, O0O.

Inglescombe Pink (Salmon Queen). Beautiful soft rosy lar flower of excellent form. Adapted for borders or late forcing. Height 22 inches. 40 cts. per doz., \$2.50 per 100, \$22.50 per 1,000 .

Inglescombe Scarlet. A very charming variety of true Cotnot be planted with Inglescombe Pink or Yellow, as they are fully 6 inches taller and resemble the Darwin type. Height 16 inches. 45 cts. per doz., \$2.75 per I00, \$25 per I,000.

Inglescombe Yellow. A beautiful variety. Size, form and geight greatly resemble the Darwin, Height 22 inches. 85 cts. per doz., \$6 per I00, \$55 per 1 , 000.

Innocence. Pure white; flowers large and of excellent form, forcing. Height 22 inches. \$I.25 per doz., \$8 per Ioo.

Isabella (Shandon Bells). Carmine-rose, shaded creamy white; doz., \$2 per Ioo, \$I 5 per I,000.

Collection of Cottage Tulips. Delivered anywhere in United States. One bulb each of 30 varieties, 30 bulbs, \$2; 6 bulbs each ps. of 30 varieties, 180 bulbs, \$ro.

\section{BOTANICAL TULIPS}

Clusiana. The "Little Lady" Tulip. A lovely little variety from Asia Minor. Grows but 8 inches high, flowers as large as Crocus, but each bulb produces several flowers. Outer petals cherry-red, inner petals white, with violet base. Io cts. each, 60 cts. per doz., \$4 per Ioo.

Fosteriana. Very brilliant scarlet, with yellow and black center; each, \$2.50 per doz., \$20 per I00.
La Candeur (Parisian White). White, changing to silvery
rose. Height I6 inches. $35 \mathrm{cts}$. per doz., $\$ 2$ per I 00, $\$$ I 7.50 per I,000.

Le Merveille. Very large, sweet-scented flowers. Salmonvariety. Height 20 inches. 35 cts. per doz., $\$ 2$ per IOO, $\$ \tau_{5}$ per I, 000 .

Leghorn Bonnet (Eleganslutea pallida). Soft primrose-yellow; variety that should be in erery collection. Height I6 inches. $50 \mathrm{cts}$. per doz., $\$ 3.25$ per Ioo, $\$ 27$ per I,000.

Miss Willmott. Undoubtedly one of the best of the Cottage straight, stiff stems. The flowers open delicate canary-yellow, but gradually become bright yellow. Height $\mathrm{I} 8$ inches. $85 \mathrm{cts}$. per doz., \$6 per I00, \$55 per I,000.

Moonlight. Bright canary-yellow; splendid, large flower, oval An excellent yellow for combination with the Darwin varieties. Excellent for late forcing. Height 22 inches. \$I.25 per doz., \$8 per Ioo.

Mrs. Moon (Fulgens maxima lutea). Deep golden yellow, large famous Parisian boulevard Tulip. Height 24 inches. 75 cts. per doz., $\$ 5$ per Ioo, \$45 per I,000.

Orange King. Beautiful deep orange, shaded rose, inside deep scented; a globular flower of great size and brilliant coloring. Most attractive for beds or borders. Height 23 inches. $85 \mathrm{cts}$. per doz., $\$ 6.50$ per I00, \$60 per I,000.

Picotee (Maiden's Blush). White, margined deep rose, the color flower, reflexing. A grand Tulip for the border. The sight of a large bed planted wholly to this variety is one that will not easily be forgotten. Height 20 inches. 30 cts. per doz., \$I.75 per IOo, $\$$ I 4 per I,000.

Primrose Beauty. Opening pale primrose, changing to color; exquisitely sweet-scented. Excellent for borders or late forcing. Height I6 inches. 50 cts. per doz., \$3.50 per I00, $\$ 30$ per I,00o.

Scarlet Mammoth. Bright scarlet, yellow base; quite the Height I 4 inches. $50 \mathrm{cts}$. per doz., $\$ 3.50$ per roo, $\$ 30$ per $\mathrm{I}, 000$.

The Fawn. The coloring is a unique shade of pale rosy fawn, on tall, strong stems. A beautiful variety. Height 20 inches. $75 \mathrm{cts}$. per doz., \$5 per I00, $\$ 45$ per I,000.

Union Jack (Distinction). Light violet, feathered purple, coloring; large flower. Excellent for forcing or border. 20 inches. \$I.50 per doz., \$Io per roo. sweet-scented. Excellent forcer. $60 \mathrm{cts}$. per doz., $\$ 4.50$ per Ioo, $\$ 40$ per I,000.

York and Lancaster. Large, long and handsome flowers, in bloom. Distinct carmine-rose, shaded white. Height 22 inches. 50 cts. per doz., \$3.50 per I00, \$30 per I,000.

Superb Mixture. A select assortment, covering almost every

doz., \$I.75 per IO0, \$ I 5 per I,000.

\section{RARE AND ODD; EARLY FLOWERING}

Greigii. Flowers very large, of brilliant orange-scarlet, with a each, \$I per doz., \$8 per I00.

Kaufmanii. Remarkably early flowering, coming in bloom two I5 cts. each, \$I.50 per doz., \$I 2 per roo.

Mauriana. Bright scarlet, yellow center; the last of all to bloom. Mauriana. 5 cts. each, 50 cts. per doz., \$3.50 per Ioo.
Vitellina. Pale yellow, becoming creamy white as the flower 


\section{SINGLE EARLY TULIPS}

SELECTED, FIRSTSIZE BULBS

In the culture of Tulips indoors, one thing is very essential. Like all bulbs to be grown under unnatural conditions, see that they have made sufficient root-growth before bringing into the light. Six bulbs of a variety to a 6-inch pot or pan, placed at even distances from one another, with the top of the bulbs about $1 / 2$ inch below the surface of the soil, is recommended. After potting, the same treatment is

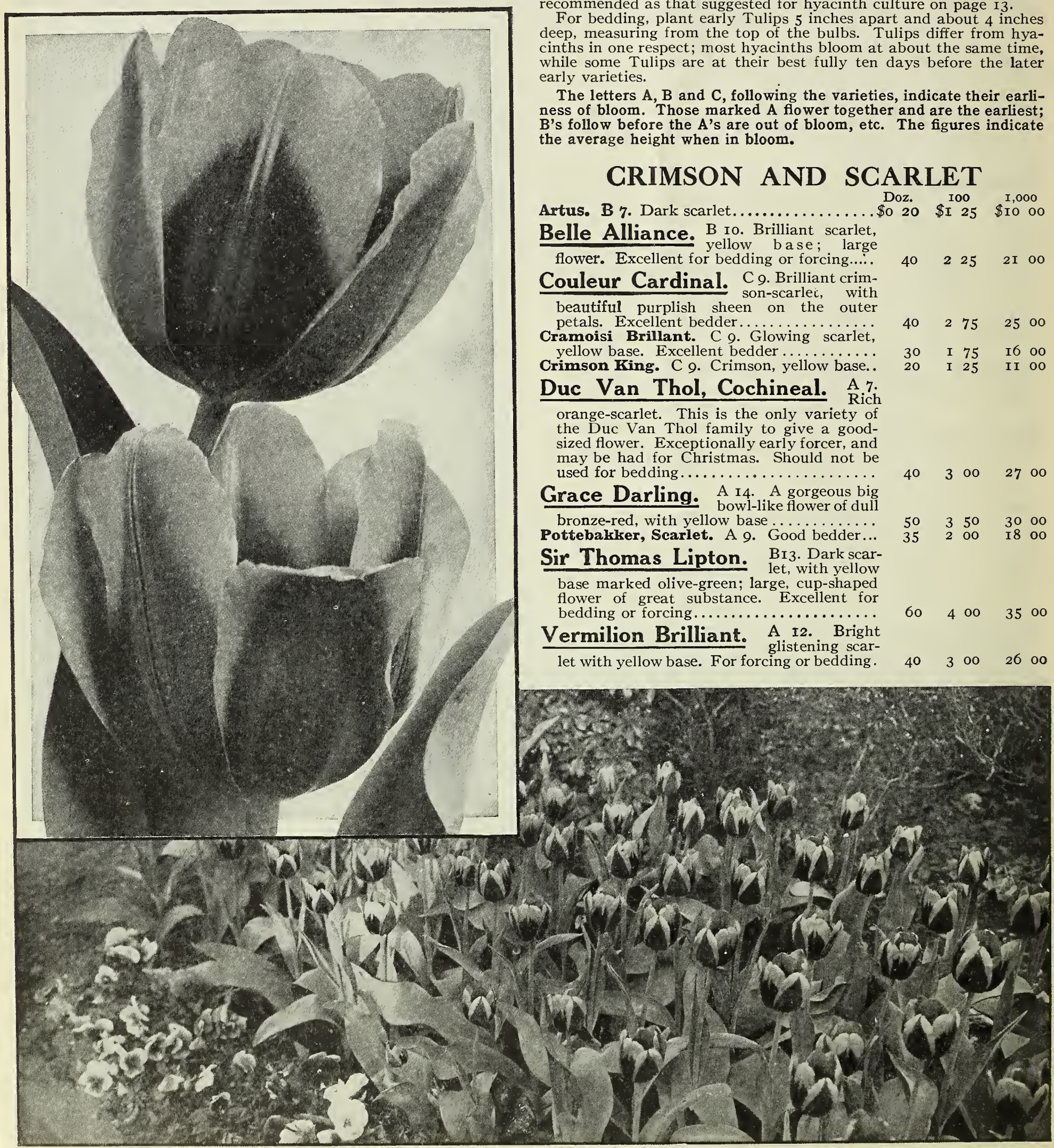

A corner of a border of Keizerkroon Tulips in Prospect Park, April, IgI2. Bulbs supplied by us 


\section{WHITE SINGLE TULIPS}

Joost Van Vondel, White. ${ }_{\text {Snowy }}^{\text {I }}$ white; large, long flower. The finest white Tulip for bedding

La Reine (Queen Victoria). B 8 . White,

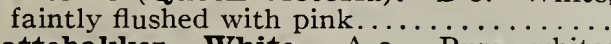

Pottebakker, White. A 9. Pure white; large and showy flower. Excellent for bedding or forcing.

Queen of the Whites. A Io. Large; pure white; splendid bedder...............

White Hawk. A ro. January forcing. Warge, pure white flower of globular form; excellent shipping variety on account of its lasting qualities........ 9. Popular park variety for

\section{PINK AND ROSE}

Cottage Maid. B 9. Rosy pink edges,

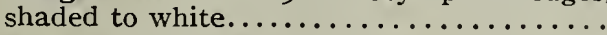

Cerise Gris-de-lin. C I I. Dark carmine-violet, shaded fawn and margined creamy white, with yellow base; large flowers of globular form; a novel bedding variety, but must be planted alone and not combined with any of the earlier varieties. Does not force well.

Flamingo (Rose Hawk). B I3. A variety that has become very popular on account of its exquisite coloring and beautiful shape. Carmine-rose, shaded lighter, with white stripe through petals.

Jenny. A 9. Beautiful velvety carminerose, on the middle of the petals a silvery white stripe, broadening toward the base. When forced in pots or pans resembles Proserpine. Good bedder.......

Le Matelas. B I2. Glistening pink, e Matelas. tipped and flushed creamy white, with yellow base; large flowers of beautiful form. Splendid for Christmas...

Le Reve. C I3. Old-rose, flushed buff e Reve. a very large, globular flower, with rounded petals and carried on a strong stem. A most beautiful variety when grown outdoors. Our representative, who spent considerable time in the bulb fields in April and May, reports it one of the finest for late bedding, or exquisite when grown in pans late..........................

Pink Beauty. C r3. Vivid cherry-rose white, white center marked yellow; enormous flower of superb form carried on stiff, strong stem. One of the best dark pink bedding Tulips; equally good if forced late.

Princess Wilhelmina (Queen of the Pinks) B. Io. Deep pink with striking white flush on outer petals; long, pointed flower.......

Proserpine. A I2. Rich, silky, carmineheads the list rose. This variety still the list for Christmas forcing......

Queen of the Netherlands. B I4. tiful, soft rosy pink, flushed white; an exquisite variety for growing in pans ........

Rose Gris-de-lin. C ro. Rose, flushed and feathered creamy white...............

Rose Luisante. C ro. Brilliant deep of great substance. Splendid for bedding or for pots and pans when forced late........

\section{YELLOW}

Chrysolora. B ro. Clear golden yellow; large, globular flower. Excellent for bedding.... Goldfinch. B ro. Pure, deep yellow; large flower; retains color exceedingly well......

\section{Doz.}

$\begin{array}{lllll}40 & \$ 3 & 00 & \$ 27 & 00\end{array}$

25 I 25 I0 00

$\begin{array}{lllll}40 & 25 & 20 & 00\end{array}$

$35 \quad 2$ o0 $\quad 18$ o0

$\begin{array}{lllll}40 & 2 & 25 & 20 & 00\end{array}$

$30 \cdot 200 \quad$ I6 00

25 I $50 \quad 1400$

$\begin{array}{lllll}75 & 5 & 50 & 50 & 00\end{array}$

$\begin{array}{lllll}75 & 5 & 50 & 50 & 00\end{array}$

$60 \quad 400 \quad 3500$

$60400 \quad 3500$

$50 \quad 7000$

$\begin{array}{lllll}75 & 5 & 50 & 50 & 00\end{array}$

$40 \quad 300 \quad 2600$

$50 \quad 400 \quad 3500$

25 I $50 \quad 1200$

$40 \quad 300 \quad 2700$

$25 \quad$ I 25 IO 00

$\begin{array}{lllll}30 & \text { I } & 75 & \text { I } 5 & 00\end{array}$

$\begin{array}{lllll}30 & 2 & 00 & 18 & 00\end{array}$
YELLOW, continued

Golden Queen. B 9. Still queen among Doz. I00 1,000 forcing or bedding. Large and fine form.... $\begin{array}{llllllll}\$ 0 & 40 & \$ 3 & 00 & \$ 27 & 00\end{array}$ Mon Tresor. A ro. Beautiful, deep yelshape. Best bedding yellow............ Pottebakker, Yellow. A 9. Large; yellow.. Primrose Queen (Herman Schlegel). edged canary-yellow; medium-sized flower of exquisite form. Fine for pot culture....... Prince de Ligny. A ro. Deep golden quisitely pointed. Fine for early forcing.. Yellow Prince. B ro. Excellent for bedding

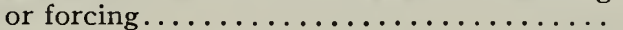

\section{STRIPED AND MARGINED}

Cardinal Rampollo. A io. Clear yelbright orange-red; a good-sized flower of a very showy character. Forces readily.

Cottage Boy. B I I. Light orange-red, edged bronzy yellow. Very showy bedder.

Duchesse de Parma. B Io. Deep orangemaroon with irregular border of deep yellow. Fabiola. B 9. Deep violet striped with white. Joost Van Vondel. B 9. Cherry-red, feathered white through center of petals....... Keizerkroon. B I2. Red, edged clear $\begin{array}{lllll}30 & 2 & 00 & \text { I } 8 & 00\end{array}$ $\begin{array}{lllll}30 & 2 & 00 & 18 & 00\end{array}$

Excellent showy bedding or forcing variety. First-size bulbs.

Extra-large bulbs.................

Le Remarquable. $\mathrm{C}$ ro. Immense stance; silky plum, shading off to silvery pink at the edges. Fine for bedding.

President Lincoln. B 9 . Clear violet; very effective contrasted with light yellows.

Prince of Austria. B Io. Brilliant orangescarlet, yellow base; large and showy flower; deliciously sweet-scented.......... Thomas Moore. B I2. Rich apricot-orange. Excellent for bedding or forcing..........

$\begin{array}{lllll}50 & 3 & 50 & 30 & 00 \\ 35 & 2 & 25 & 20 & 00 \\ 30 & 1 & 75 & 15 & 00 \\ 40 & 3 & 00 & 28 & 00 \\ 30 & 2 & 00 & 18 & 00 \\ & & & & \\ 25 & \text { I } & 50 & 14 & 00 \\ 35 & 2 & 25 & 20 & 00 \\ & & & & \\ 75 & 5 & 50 & 50 & 00 \\ 50 & 3 & 25 & 30 & 00 \\ 30 & 2 & 00 & 18 & 00 \\ 25 & \text { I } & 50 & 12 & 00\end{array}$

\section{S. \& W. CO.'S SPECIAL MIXTURE}

A mixture consisting of 25 named varieties, blended so as to give an assortment of all possible colors and shades, all of vigorous habit and large size, uniform height and time of blooming. $30 \mathrm{cts}$. per doz., \$2 per Ioo, \$I 5 per I,000.

\section{Color Scheme Suggestions for Beds COMBINATIONS}

Chrysolora and Belle Alliance.

Duchesse de Parma and White Hawk.

Prince of Austria and Vermilion Brilliant.

Artus and La Reine.

Pottebakker, White and Mon Tresor.

\begin{tabular}{ll}
\multicolumn{1}{|c}{ BEDS OF ONE VARIETY } \\
$\begin{array}{l}\text { Pink Beauty. } \\
\text { Proserpine. } \\
\text { Cerise Gris-de-lin. }\end{array}$ \\
Coulerkroon.
\end{tabular}

VARIETIES RECOMMENDED FOR FORCING

SECTION 1.-To flower late December and early January: Duc Van Thol, Cochineal, Belle Alliance, Vermilion Bril: liant, Grace Darling, La Reine, Pottebakker, White; White Hawk, Mon Tresor, Golden Queen, Le Matelas, Proserpine, Thomas Moore, Prince of Austria, Keizerkroon and Duchess de Parma.

SECTION 2.-For flowering late January to early March: Sir Thomas Lipton, Chrysolora, Goldfinch, Primrose Queen, Prince de Ligny, Cardinal Rampollo, Pink Beauty, with all of the varieties listed in Section $\mathrm{I}$.

SECTION 3.-Couleur Cardinal, Le Reve,La Remarquable, Rose Luisante, with all the varieties listed in Sections I and 2. 



The Tulips listed below can be relied upon to flower at the same time, and be of the same height. The most effective varieties have been chosen for producing a brilliant display in masses. They should be planted not more than 5 inches apart, covering the bulbs about 4 inches from the top, and covering the beds or borders with old leaves to prevent hard frost from entering, as well as protect from the early spring frost, which frequently spoils the foliage, rendering it unsightly when the bulbs flower.

\section{SINGLE EARLY TULIPS}

For flowering at the same time

Matchless Bedding White ......... \$o 30

Matchless Bedding Rose-Pink ............ 30

Matchless Bedding Yellow............... 30

Matchless Bedding Orange ............... 30

Matchless Bedding Scarlet ............... 30

Matchless Bedding Pink-and-White .... 30

\section{DOUBLE EARLY TULIPS}

For flowering at the same time

$\$ 200$

200

200

200

200

200
Matchless Bedding White ......... \$o 30

Matchless Bedding Rose-Pink ........ 30

Matchless Bedding Yellow............ 30

Matchless Bedding Orange.......... 30

Matchless Bedding Scarlet .......... 30

Matchless Bedding Pink-and-White ..... 30
$\$ 200$

200

200

200

200

200 


\section{DOUBLE EARLY TULIPS}

Double Tulips have massive flowers of brilliant and varied colors, shades and markings, and, being double, the flowers last much longer in bloom than single varieties; in consequence, when singles and doubles are planted together, the "Time of the Tulips" is greatly prolonged. Double Tulips are beautifully adapted for beds on the lawn, in the garden and for mingling in clumps of half a dozen or more around the edges of shrubbery. All are robust growers and exceedingly effective.

The following list of Double Early Tulips has been selected after a painstaking test of a large number of varieties, and consists of the best and most modern varieties.

Blanche Hative. B 9. Beautiful, Doz. roo r,000 early white...............\$0 $30 \quad \begin{array}{lllll}\$ 2 & 25 & \$ 20 & 00\end{array}$ Cochineal. $\mathrm{C}$ ro. Brilliant scarbest double scarlet..............

Crown of Gold (Couronne

Large, bold flowers of rich golden yellow, shaded copper. Excellent for bedding or forcing............

El Toreador. B Io. Bright broadly margined buff-yellow.....

Imperator rubrorum. A 9 .

of the best scarlets either for bedding or forcing. Still remains among the best of the older varieties.

La Candeur. B Io. Excellent white variety for bedding.............

Golden King. A I $2 . \quad$ S of $t$ shaded deeper yellow; very large

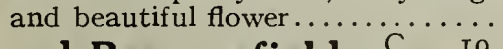

Lord Beaconsfield. $\mathrm{C}$ ro. ful dark pink flower; excellent for forcing or bedding.

Lucretia C Io. One of the deepest pinks; flowers of enormous size; each flower has a number of petals protruding from the others.

Matador. B Io. Bright red; splendid forcer... . . . . Magnificent blushwhite, shaded rose; large flowers; fine for cutting.

Rubra maxima. B 9. Deep dazzling scarlet; much superior to that popular variety, Rex rubrorum

Safrano (Brimstone). B 9 . A Tulip, opening soft saffron shade, but developing a rosy apricot in a day or so....................

Salvator Rosa. A 8. Deep rose, flamed white................. Snow-white.

Schoonoord. A 9 . Snow-white. The best double white............ Excellent variety for early forcing.

Tournesol. A 9. Splendid, showy Tulip. Orange-scarlet, with broad yellow tips and base; very large, double flower.

$50 \quad 400 \quad 3500$

$40 \quad 275 \quad 2500$

$60 \quad 450 \quad 40 \quad 00$

$\begin{array}{llllll}40 & 2 & 25 & 2 \mathrm{I} & 00\end{array}$

$30 \quad 200 \quad 1800$

$50 \quad 1200$

$\begin{array}{lllll}50 & 3 & 00 & 25 & 00 \\ 75 & 4 & 00 & 35 & 00 \\ 50 & 3 & 00 & 25 & 00 \\ 25 & \text { I } & 75 & \text { I5 } & 00 \\ 30 & 2 & 00 & \text { I } 5 & 00\end{array}$

$60 \quad 500 \quad 4500$

25 I 75 I 5 oO

$75 \quad 550 \quad 5000$

$\begin{array}{lllll}30 & 2 & 25 & 20 & 00\end{array}$

Tournesol, Yellow. A 9 . Bright golden yellow; shaded orange; large and showy........

Vuurbaak. B ro. Fiery scarlet, tinged orange when open. Excellent for beds or forcing

S. \& W. Co.'s Special Mixed...

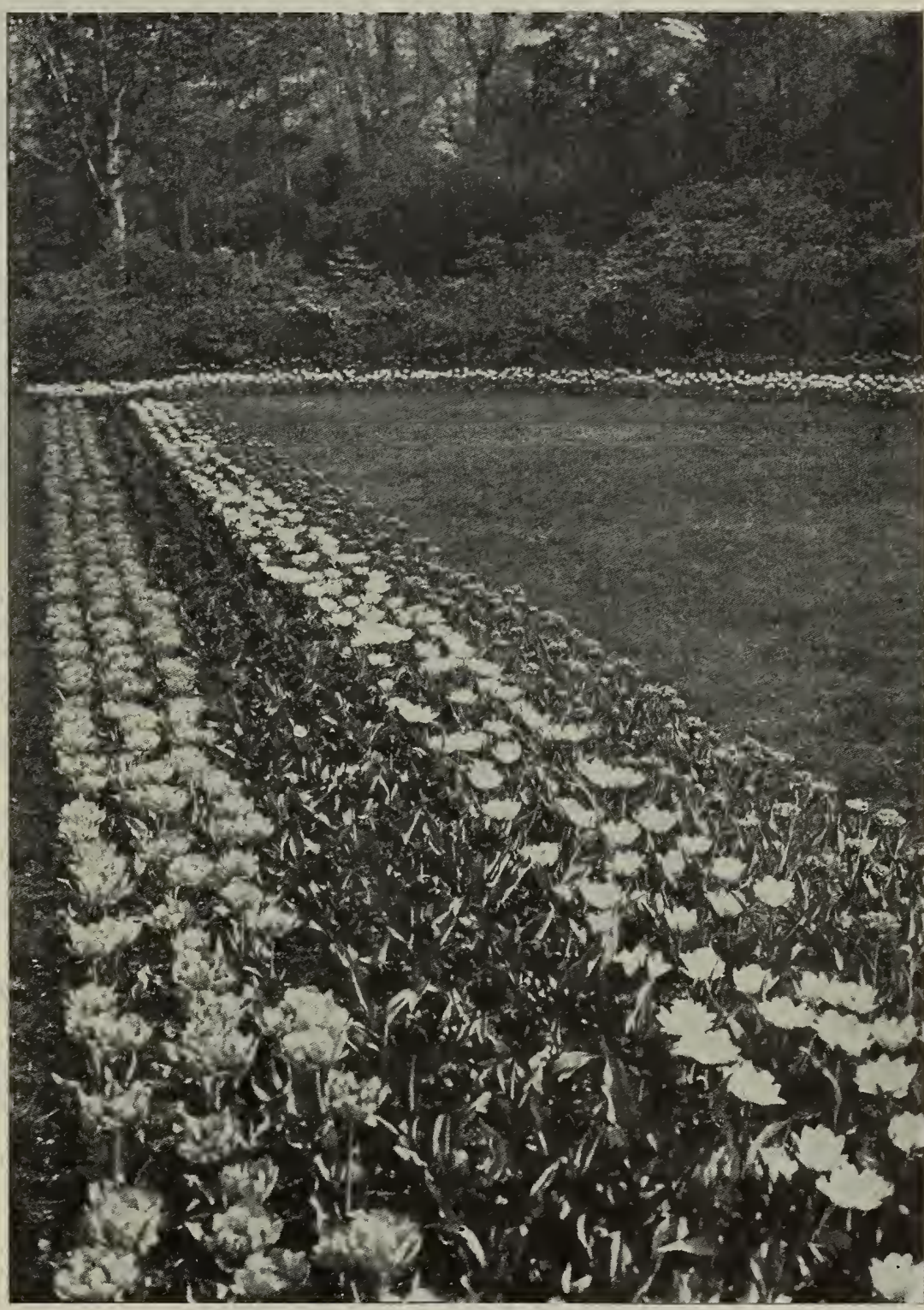

Double Tulips

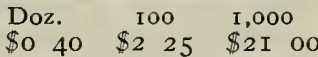

$\begin{array}{lllll}35 & 2 & 50 & 22 & 50\end{array}$

25 I $00 \quad 900$

\section{REMBRANDT TULIPS}

A break from the finest types of Darwins. Size of flowers, form and height are the same as Darwins. They are all perfectly hardy and, combined with their delicate colorings and markings, are bound to win popularity.

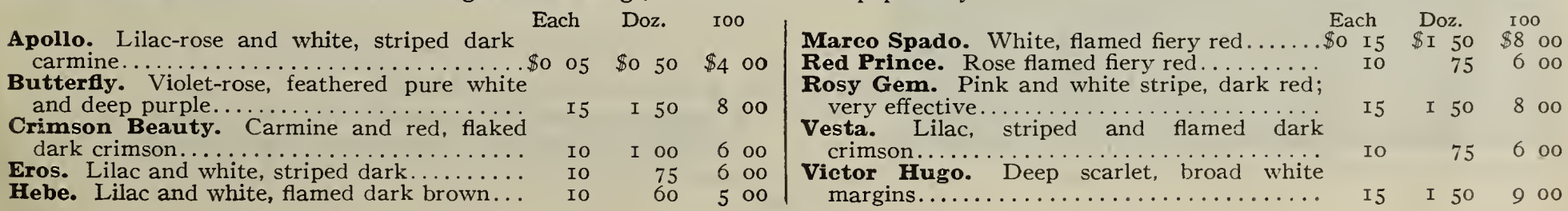




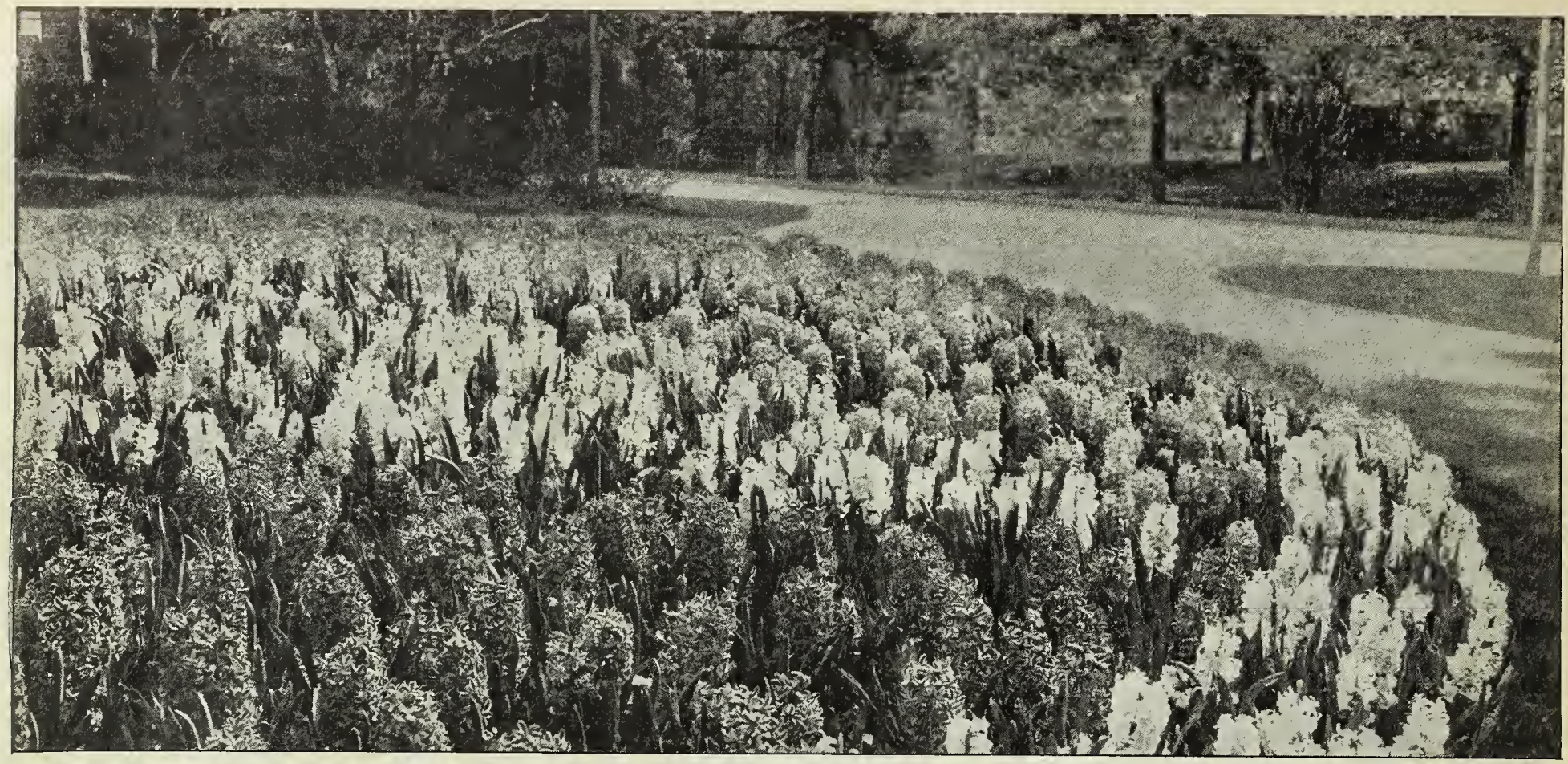

\section{MATCHLESS BEDDING HYACINTHS}

Special named varieties in distinct shades of color, to flower at the same time BULBS MEASURE 7 TO 8 INGHES IN GIRGUMFERENGE

The Hyacinth chosen to represent each of the following shades of color is a variety which, we have found from trials, will be best in the three essential requirements: Best in its color; stoutest stem; largest truss of bells; so our customers will know that we have avoided using such varieties that are of weak stem, and that do not support the blooms.

\section{CULTURE}

These Hyacinths should be planted from 6 to ro inches apart, and covered with at least 4 inches of soil from the top of the bulb. For beds or borders close to the conservatory or dwelling, 6 inches will make a fine display; but where the beds are planted to be viewed from a distance, they may be planted Io inches apart. Hyacinths planted alternately with narcissi produce a most graceful effect, and for this combination 6 inches from bulb to bulb is also a very suitable distance. It is advisable to cover, after the bulbs have been planted, with leaves or some heavy material that will prevent them from freezing or being affected by early spring frosts after they have started.

Hyacinths, as well as narcissi, should be planted by November first in this latitude, as they are the better for early planting. Tulips may be planted up to December first, weather permitting.

Deliverzd (by express or Parcel Post) anywhere in the United States free

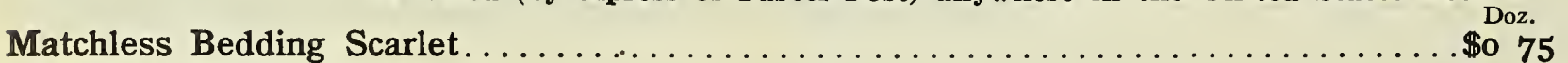

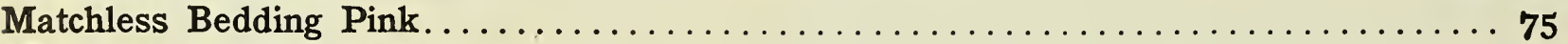

Matchless Bedding Light Rose . . . . . . . . . . . . . . . . . . . . . 75

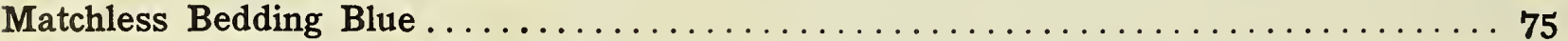

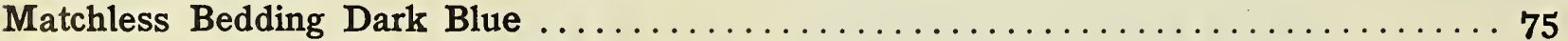

Matchless Bedding Pure White ............................. 75

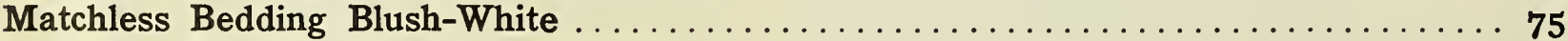

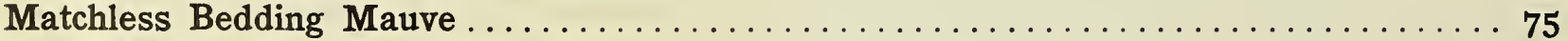

Matchless Bedding Deep Yellow...

$\$ 500$

500

500

500

500

500

500

500

500 $\mathrm{r}, 000$

$\$ 4500$

4500

4500

4500

4500

4500

4500

4500

4500

Suggestions for Effective Color Combinations

1. Matchless Bedding Pink and Light Blue.

2. Matchless Bedding Light Blue and Deep Yellow.
3. Matchless Bedding Light Blue and Dark Blue.

4. Matchless Bedding Dark Blue and Deep Yellow. 


\section{MATCHLESS

\section{FIRST-SIZE BULBS}

Any good soil will grow Hyacinths, but they do best in a rich, light one. Our Matchless Forcing, New and Choice, Named Exhibition Hyacinths may be planted singly in a 5-inch pot or four bulbs of one variety to a 7- or 8-inch bulb-pan, a piece of broken pot placed across the hole in the bottom, then a layer of moss about an inch deep to provide proper drainage. Place the bulb in the pot so as to be about half an inch below the surface of the soil. Remove all the offsets from the bulb before potting, and have the soil come up to within an inch from the top of the pot to permit watering when bulbs are growing. Bulbs so potted may be "plunged" out in the open garden and covered with about 6 inches of gravel or ashes. This will admit of their getting the proper amount of moisture and still prevent damage by frost. See that there is a firm bed of ashes beneath the pots, so as to prevent the entrance of worms. They may also be put in a coldframe, or cool cellar, and kept well watered. Should be kept out about twelve weeks, except Roman Hyacinths, which take only about nine weeks to develop fibrous roots, which are essential to the proper development of large spikes of bloom. A very frequent mistake is made in bringing the bulbs into the light too soon, resulting in a failure to bloom, or else weak spikes. After lifting, see that the temperature for the first two weeks is quite low (50 degrees) until the top-growth has nicely developed, when they may be forced according to one's needs. By keeping near to the glass so as to avoid becoming drawn, with a liberal supply of air, strong spikes of bloom may be had. Avoid, under all circumstances, direct bottom heat.

The figures, $1,2,3,4$, indicate relative time of blooming -1 being early; 4 the latest.

If wanted by mail, add 15 cts. per dozen to cover postage

\section{SINGLE PINK}

Gertrude. 3. Dark pink; compact spike. Excellent for Doz.

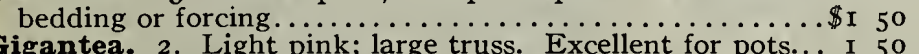
Gigantea. 2. Light pink; large truss. Excellent for pots.:.
Jacques. 3. Very pale pink; large truss and bells. Splendid

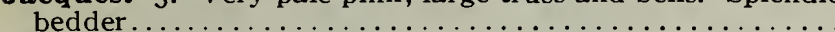

Lady Derby. I. Soft blush, shaded pink; large truss and bells. Splendid for pot culture................

Moreno. I. Bright rosy pink; heavy truss, large bells.

Suitable for pot culture only ................. I 25

Rosea maxima. I. Excellent; delicate pink............ I 50

\section{SINGLE RED}

Garibaldi. r. Deep crimson-red; large spike. Best early

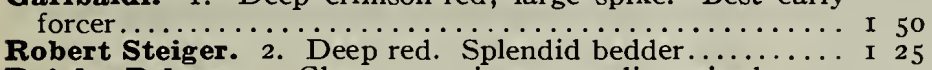

Roi des Belges. 2. Clear rosy crimson; medium-sized, compact truss. Splendid for bedding............... I 25

\section{SINGLE BLUE}

Czar Peter. 2. Light lavender-blue; splendid spike, with large, waxy bells................................... Grand Maitre. 2. Dark lavender-blue; large bells

King of the Blues. 4. Bright dark blue; splendid spike and bells. Excellent for late forcing or bedding......... I 50 La Peyrouse. 3. Clear porcelain-blue; large bells. Excel-

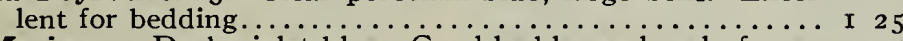

Marie. 2. Dark violet-blue. Good bedder and early forcer. I 25

Potgieter. 2. Light blue. Good for bedding or forcing.... I 50

Regulus. 2. Light blue. Good early forcer............. I 50

Schotel. I. Soft light blue; very long and perfect truss with large bells. Easily forced; splendid bedder.

\section{SINGLE WHITE}

Baroness Van Thuyll. x. Snow-white, large, compact

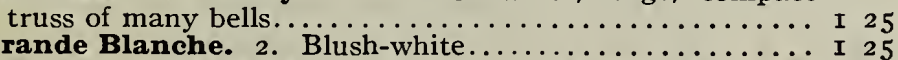
Grande Blanche. 2. Blush-white................... lent forcer as well as bedder.................. I 50

La Franchise. 3. Creamy white; large bells and spikes. Excellent bedder.

La Grandesse. 3. Pure white, waxy bells. The finest for

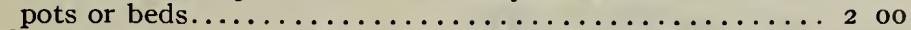

L'Innocence. I. Pure white; fine truss; bells large and of good substance. Fine for pots or bedding.......... 2 oo Mme. Van der Hoop. 2. Pure white; large bells........ I 50

\section{SINGLE YELLOW}

Ida. 3. Canary-yellow; tall. Fine forcer............ I 50 King of Yellows. 4. Deep yellow; large bells............ I I 50 Marchioness of Lorne. 3. Orange-yellow; excellent truss. I 50

Yellow Hammer. 3. Soft dark yellow; splendid spike and bells.

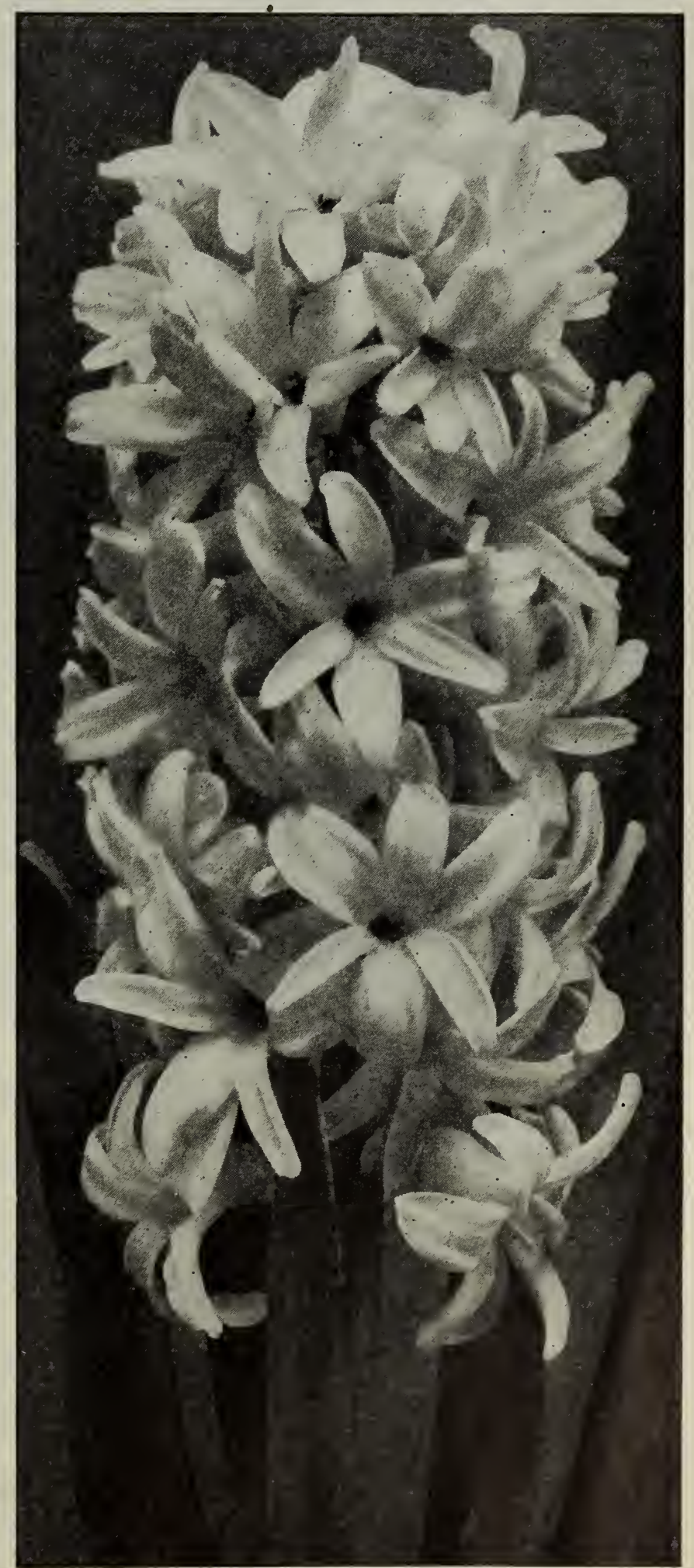

Single Hyacinth, La Grandesse 


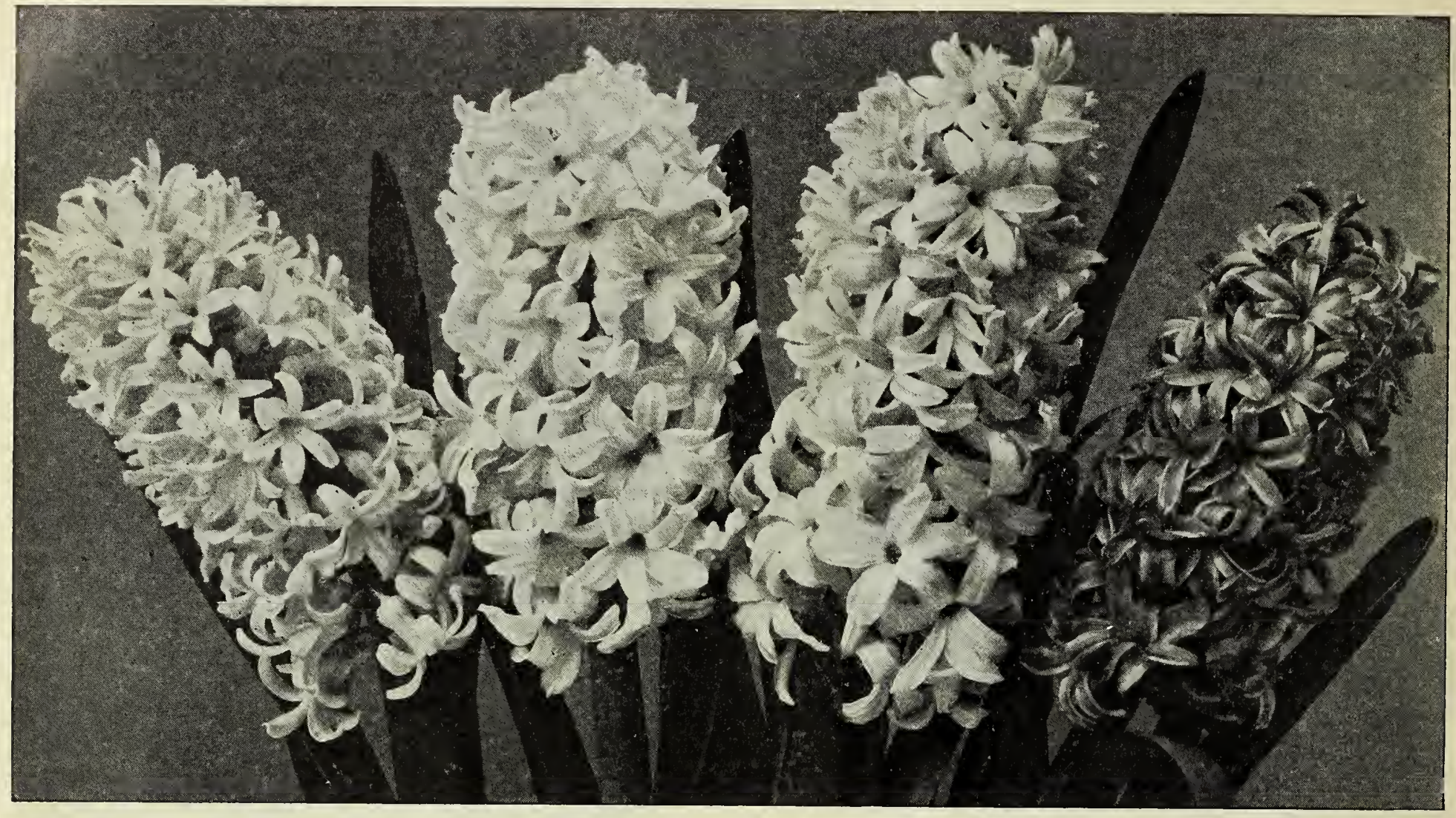

\section{S. \& W. Co.'s New and Choice Hyacinths}

The increased demand on the part of Hyacinth enthusiasts has led to the more extensive cultivation of Novelty Hyacinths in Holland. Many of the varieties listed below are much superior in strength of spike and perfectly formed trusses of beautiful, large bells, as well as more vivid coloring over any of the standard sorts. Where Hyacinths are desired for "exhibition purposes" we can unreservedly recommend them for that purpose, or for growing in pots or glasses for winter flowering in the house.

Arentine Arendsen. I. Pure, snowy white; open, widespike. Extra-fine variety. 20 cts. each, $\$ 2$ per doz.

Bismarck. 2. A grand new variety producing a large spike well furnished with immense bells of charming light blue, Buff Beauty. 2. Buff-orange-yellow, a very unusual color. ExDaylight. 2. Primrose-yellow; best of its colors. 25 cts. each, Daylight. $\$ 2.50$ per doz.

Etna. 4. Beautiful bright dark rose; very large, full truss with large bells; one of the latest to flower. Unexcelled for pot culture. 20 cts. each, $\$ 2$ per doz.

Enchantress. 2. Beautiful porcelain-blue; unusually long and each, $\$ 2$ per doz.

General DeWet. 2. A pink Grand Maitre. Strong spike; bells of soft, light pink. Fine for pots and bedding. 25 cts. each, $\$ 2.50$ per doz.

Hofgaertner Kunert. 2. Beautiful blush-pink, sport of Genof pyramidal form with large bells. 25 cts. each, $\$ 2.50$ per doz.
L Victoire 2. Bright, glistening red when flowering outdoors; a under glass a fine dark pink. Brilliant bedding sort of lasting color. 20 ets. each, $\$ 2$ per doz.

Lord Balfour. I. Lilac-rose, tinged dark violet; distinct in a grand sight. 20 cts. each, $\$ 2$ per doz.

Menelik. 2. Deep black-blue; the darkest of all the Hyacinths. 25 cts. each, $\$ 2.50$ per doz.

Monsieur Vanderhoop. I. Great, broad, well-belled spike bells. 20 cts. each, $\$ 2$ per doz.

Perle Brillant. 2. Light blue, tinged lavender; big bells on a large, finely formed spike; handsome and impressive. 20 cts. each, $\$ 2$ per doz.

Queen of the Pinks. 4. This splendid novelty is a sport of has the same brilliancy as the of the Blues. The pink color variety for pot culture. 40 ets. each, $\$ 4$ per doz.

White Lady. 2. An immense pure white sport of the blue White Lerby; handsome, large bells on large strong spikes. 25 cts. each, $\$ 2.50$ per doz.

\section{NAMED EXHIBITION HYACINTHS}

Every year our grower makes a selection of the largest bulbs that can possibly be obtained in the Best Named Hyacinths for Exhibition purposes, and frequently finds it impossible to fill our order (except for a limited quantity) from his stocks, and is obliged to scour the entire Hyacinth-growing districts for them. We offer the following 12 varieties, subject to being unsold on receipt of oider, at 20 cts. each, $\$ 2$ per doz., $\$ 15$ per 100 .

Grand Maitre. Best dark blue.

Queen of the Blues. Best porcelain-blue. Potgieter. Best light blue.

Marie. Best violet-blue.
La Grandesse. Grand pure white.

L'Innocence. Fine pure white.

La Franchise. Best creamy white.

Lady Derby. Best blush-pink.
Gertrude. Best dark pink.

Roi des Belges. Best crimson.

Moreno. Best rosy pink.

Yellow Hammer. Best yellow. 


\section{Dutch Roman or Miniature Hyacinths}

The following method of growing Hyacinths for winter flowering in the house has given the most satisfactory results. A number of florists use it for creating something new in the line of an Easter display, with the result that there is always a much greater demand than supply, owing to the beautiful display the Hyacinths in pans make. The secret of acquiring success is simply the following: Plant only one kind in a pan, in order to have them all bloom at once, and to have them all the same shade. The following varieties are the best sorts. By planting Io to I 2 bulbs of any one variety mentioned, in a pan 8 to 9 inches in diameter, and following the directions for planting in pots, the most satisfactory results will be obtained. In ordering bulbs for this purpose, be sure to mention Miniature Hyacinths.

Gertrude. Fine pink.

Roi des Belges. Bright red.

Cardinal Wiseman. Rosy carmine.

Gigantea. Pale pink.

L'Innocence. Pure white.

La Grandesse. Pure white; large spike.

Grandeur a Merveille. Blush-white.

Baroness Van Thuyll. Snow-white.

Grand Maitre. Bright blue.

King of the Blues. Dark blue.

Queen of the Blues. Porcelain-blue; extra fine.

Price of any of above named varieties 50 cts. per doz.,

by mail, postpaid; or $\$ 3$ per 100 by express, prepaid

\section{$\underline{\text { Roman Hyacinths }}$}

Treat like the other Hyacinths. They come into flower earlier, and should, for first flowers, be brought in by November I5; by so doing they will give their flowers in perfection by Christmas. Their great beauty is in their profusion of flowers, each bulb giving from three to six spikes. The flowers are smaller than those of the Dutch Hyacinths, but are more graceful. The bulbs being small, three can be put in a 5inch pot.

White, Jumbo

White, Mammoth.

White, I3 to $15 \mathrm{~cm}$.

White, I 2 to $15 \mathrm{~cm}$.

Single Rose, I 2 to I $5 \mathrm{~cm}$.

Single Blue, I 2 to $\mathrm{I} 5 \mathrm{~cm}$.

Single Yellow, I 2 to I $5 \mathrm{~cm}$.

Double Rose, I 2 to $15 \mathrm{~cm}$.

White Italian, I 2 to $\mathrm{I} 5 \mathrm{~cm}$.

If wanted by mail, add 10 cts. pe

\begin{tabular}{|c|c|c|}
\hline Doz. & I00 & $\mathrm{I}, 000$ \\
\hline I 100 & $\$ 650$ & $\$ 6000$ \\
\hline 75 & 50 & 50 \\
\hline 60 & 450 & 4000 \\
\hline 50 & 400 & 3500 \\
\hline 40 & 325 & 3000 \\
\hline 40 & 325 & 3000 \\
\hline 75 & 500 & 4500 \\
\hline $5^{\circ}$ & 375 & 3250 \\
\hline 40 & $\begin{array}{ll}325 \\
\end{array}$ & 3000 \\
\hline
\end{tabular}

\section{Selected Unnamed Hyacinths}

These Hyacinths are all large-sized, healthy bulbs, well adapted for outdoor planting. The colors being kept separate, the purchaser can make his selection of colors as his taste may dictate. The bulbs can also be forced for winter flowering or cutting. Bedding and forcing varieties are kept separate. Please state which to send, when ordering. Delivered free in United States.

\section{SINGLE HYACINTHS}

$\begin{array}{cccc}\text { Pure White } & \text { Rose } & \text { Light Blue } & \text { Yellow } \\ \text { Blush-White } & \text { Red } & \text { Dark Blue } & \text { Selected Mixed } \\ 5 \text { cts. each, } 50 \text { cts. per doz., } \$ 4 \text { per 100, } \$ 35 \text { per 1,000 }\end{array}$

\section{DOUBLE HYACINTHS}

$\begin{array}{llll}\text { Pure White } & \text { Rose } & \text { Light Blue } & \text { Yellow } \\ \text { Blush-White } & \text { Red } & \text { Dark Blue } & \text { Selected Mixed }\end{array}$
5 cts. each, 50 cts. per doz., $\$ 4$ per $100, \$ 35$ per 1,000

\section{Double Named Hyacinths}

The following list of Double Hyacinths are the best varieties. While these are grown by many, they do not produce so large spikes as the single sorts, and should not be grown in glasses.

Bouquet Royal. Rose, dark shaded.

Bouquet Tendre. Carmine-red. Chestnut Blossom. Blush-pink. Kohinoor. Fine pink.

Noble par Merite. Deep pink.

Prince of Orange. Semp pink.
La Tour d'Auvergne. Earliest pure white; fine spike and bells.

La Grandesse. Best white.

Princess Alice. Pure white.

Blocksberg. Porcelain-blue.

Garrick. Lilac-blue.
General Kohler. Best bright blue. Large bells on a strong, stiff spike.

Lord Raglan. Lilac-blue.

Goethe. Light yellow.

Jaune Supreme. Splendid, rich yellow. William III. Yellow, tinted orange. 


\section{NEW AND RARE NARCISSI}

\section{King Alfred}

See 1llustration on Front Cover

\section{THE GREAT GIANT GOLDEN YELLOW NARCISSUS}

Conceded to be the Most Conspicuous Exhibit in Section B of the International Flower Show in New York City this Spring

DESCRIPTION: The trumpet itself is a rich, deep, pure yellow. It is of great size and substance, and is exquisitely finished; the mouth is turned well back, and is beautifully frilled. The perianth, or petals, are of the same rich yellow shade as the trumpet, very thick and strong, and are magnificently formed, thus making it a perfect setting for the trumpet which it carries. The foliage is strong and, like the flower, of excellent proportion and substance, with a delicate glaucous tint. One of the best forcing varieties of the Giant Trumpets. Price, 75 cts. each, $\$ 8$ per doz., $\$ 65$ per 100.

\section{$\frac{\text { ARIADNE }}{\text { (Leedsii) C. }}$}

Perianth ivory-white; cup pale amber-yellow passing to white; broad, widely expanding, and most regularly and beautifully frilled; a good-sized flower of exquisite beauty, lasting long in bloom. Splendid for border planting and excellent for pots. Height 16 inches. 15 cts. each, $\$ 1.25$ per doz., $\$ 9$ per 100 , $\$ 80$ per 1,000 .

\section{BEAUTY \\ (Incomparabilis) $\mathrm{C}$.}

Perianth pale sulphur-yellow; cup deep yellow, elegantly margined orange-scarlet. A striking flower for the border and equally fine for pot culture. Height I 7 inches. 10 cts. each, 75 cts. per doz., $\$ 5$ per $100, \$ 40$ per 1,000 .

\section{FRANK MILES}

$$
\text { (Incomparabilis) C. }
$$

Perianth pale yellow, elegantly twisted; cup bright yellow; large, handsome flower. Appears to excellent advantage planted in clumps in the border; also grown extensively for cutting; very good for pot culture. Height 2 I inches. 5 cts. each, 50 cts. per doz., $\$ 3.50$ per $100, \$ 30$ per 1,000 .

\section{FIREBRAND}

(Barrii) D.

Perianth creamy white, shaded pale yellow at the base; cup of most intense fiery red, prettily fluted; a variety that is remarkable for its brilliance of color. Excellent for shrubbery borders or positions that are shaded, where the intensity of the color is well preserved. May be grown to excellent advantage in pots if forced gently. Height 7 inches. 15 cts. each, $\$ 1.50$ per doz., $\$ 10$ per 100 , $\$ 95$ per 1,000 .

\section{LUCIFER}

(Incomparabilis) C.

Perianth sulphur-white, with long, well-rounded petals; rather star-like in effect; cup chrome-yellow, edged bright orange. A bold, showy flower for outdoors, holding its color well, and splendid for pot culture. 25 cts. each, $\$ 2.50$ per doz., $\$ 18$ per 100.

\section{SEA GULL \\ (Barrii) C.}

Broad perianth of the purest white; cup pale lemon-yellow; an exquisitely beautiful flower, perhaps the very loveliest of this class. Equally fine for bedding or forcing. 25 cts. each, \$2 per doz., $\$ 15$ per 100 .

\section{VANILLA \\ (The Sweet-Scented Giant Trumpet)}

This is a grand, tall-growing and very handsome variety, having a fine, bold trumpet of deep yellow with a paler perianth, and possessing the added charm of a most pleasing and delicate odor. It flowers the same time as Emperor, and is a good variety for forcing. Height 20 inches. 15 cts. each, $\$ 1.50$ per doz., $\$ 10$ per 100 .

\section{WHITE LADY}

(Leedsii) C.

Broad, white perianth of perfect form; small cup of pale canary, beautifully crinkled. A new sort that is conceded to be one of the best. Fine for outdoor planting, making a splendid cut-flower; good for pot culture also. Height 20 inches. 15 cts. each, $\$ 1.50$ per doz., $\$ 10$ per $100, \$ 90$ per 1,000 .

\section{CHARMING POETAZ NARGISSUS, ALSACE}

(The Bunch-Flowered Poet's Narcissus) C.

This is a very fine Narcissus for planting in pans, having the good characteristic of the Polyanthus, or Many-flowered Narcissus, with a charming fragrance, and the true Poet's flower, with its slender but strong stem. The perianth is pure white, the cup or eye, yellow. When bursting into flower the eye is quite reddish but immediately turns yellow. It is earlier than Poeticus ornatus, and comes generally with four large flowers to the stem. Excellent for border planting in clumps with a few bulbs of Muscari, or Grape Hyacinth, Heavenly Blue, planted around them. 50 cts. per doz., $\$ 3.50$ per $100, \$ 32.50$ per 1,000. 


\section{NARCISSI, DAFFODILS AND JONQUILS}

No garden would be complete without the Narcissi, which include Daffodils and Jonquils. The innumerable positions in the garden in which their use may be availed of is responsible, in a measure, for their popularity. This fact, and the simple beauty of form, dignity of habit, elegance of bloom and ease of culture, accounts for the new interest amounting to enthusiasm of flower-lovers of all Europe. Each year

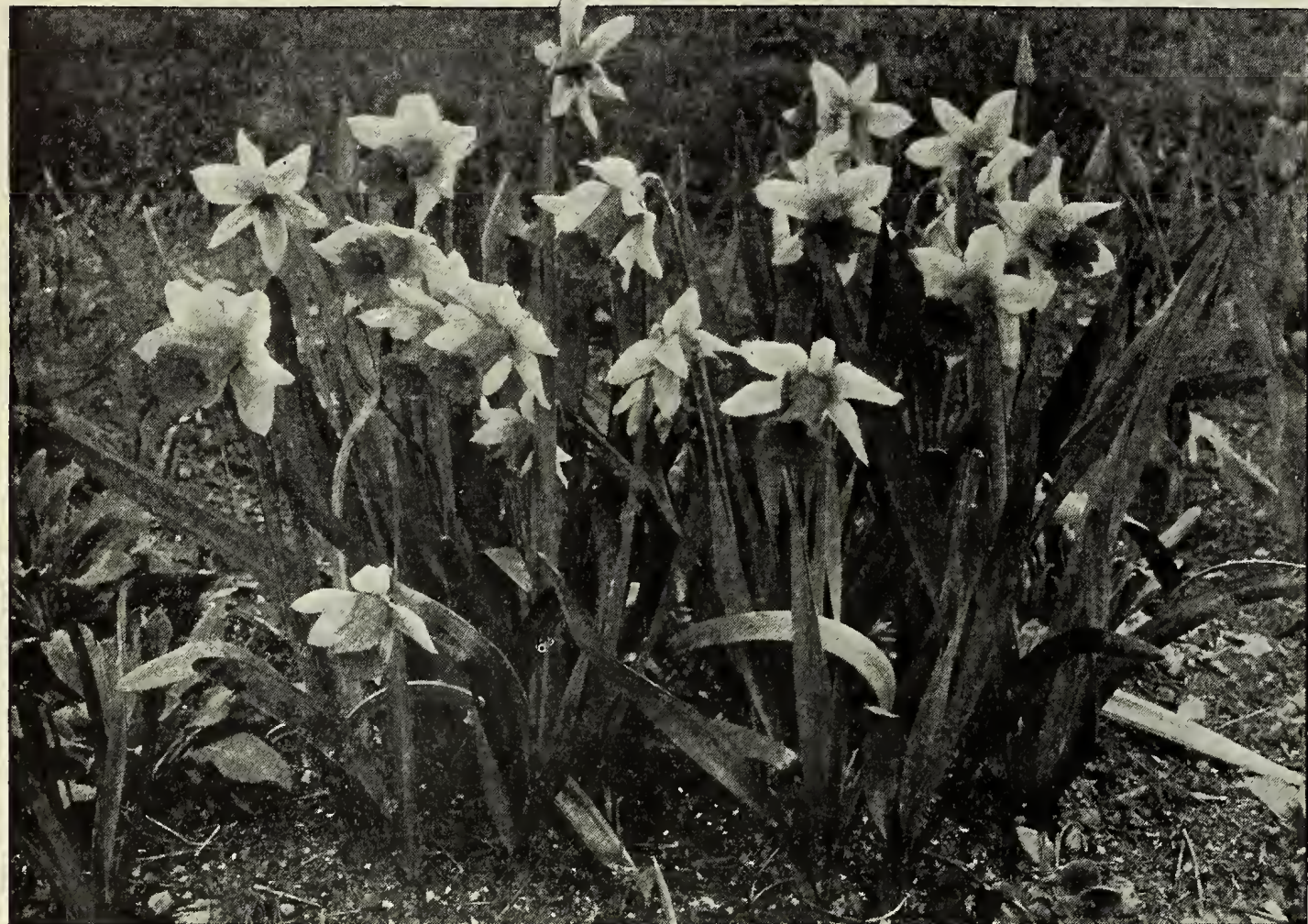

Empress Narcissi we are greeted with a horde of novelties

To the enthusiast who scrupulously measures the depth or the exact reflexing of some New Giant Trumpet variety, or the width of its unusually broad perianth; who admires the quiet grace of its most perfect form and the beauty of its color, these new novelties are of much concern.

They may be grown in the modest town garden; or clumped, here a mass of one variety and there another, in the herbaceous border. As a border for shrubbery they attain their full measure of graceful splendor; for natural plantation, outlying portions of the lawn or grounds, on terrace slopes, or banks of streams, and along woodland driveways, millions of bulbs are yearly planted.

Culture.-Owing to the various sizes of the bulbs, it is not advisable to state the exact depth to plant, but the simple rule of covering the bulb one and onehalf times its own depth; and the distance between the bulbs 3 to 4 inches for smaller sorts and 5 to 6 inches for the larger ones, is a good one. For greenhouse or window-garden culture treat them the same as hyacinths, except that three or more bulbs of one variety should be planted in a pot, and not single specimens.

Where a succession of blooms is desired for outdoors as well as indoors, we have arranged the following code: A, first early; B, second early; C, midseason; D, late; E, very late.

NoTE.-In describing Daffodils, Narcissi, etc., we have referred to the "perianth" and "trumpet," "crown" or "cup." The "perianth" is the surrounding row of petals or wings, and the other terms apply to the central funnel-like tube.

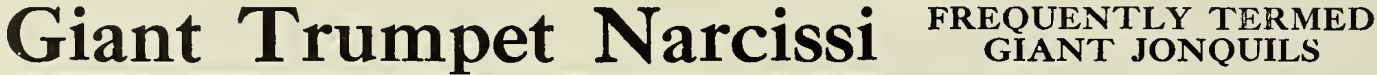

\section{HAVE GIGANTIC TRUMPETS AND MASSIVE PERIANTHS}

Note.-The designations Jonquils, Daffodils or Narcissi are of ten misapplied by amateurs, and the result invariably means, disappointnient. "Jonquil" is a popular name given to all Single Trumpet Narcissi, regardless of any other form or class. "Daffodil" is the name applied to all Double Narcissi. The name "Narcissus" calls for the Poet's Narcissus and its family; also the Paper-White Narcissus or the Polyanthus variety.

In order to avoid confusion of technical terms, we have listed all Ajax Narcissi as Giant Trumpets; Barrii, Incomparabilis, Leedsii and Bulbocodiums as Medium Trumpets.

\section{If ordered to be sent by mail, add 12 cts. per doz. lor postage}

Beethoven. A. Pale chrome-yellow perianth and trumpet, selfcolor; very distinct form of flower; one of the most refined forms we have seen; very long stem; the healthy foliage has a bluish green tint. Splendid for the border or early forcing. Height I 4 inches. 10 cts. each, 60 ets. per doz., $\$ 4$ per $100, \$ 35$ per 1,000 .

Empress. C. White perianth of great substance; trumpet rich naturalizing. Does equally well forced. Height 18 inches.

Jumbo bulbs...............

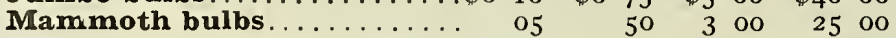

Emperor. C. Perianth deep primrose-yellow, broad at base, trumpet rich yellow; a very large flower of remarkable

Jumbo bulbs $\quad$ Each Doz. 100 1,000

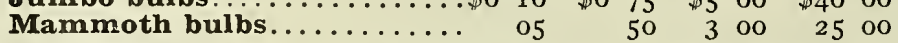

Glory of Leyden. C. Perianth pale yellow, broad and spreadenormous flower of great vigor and substance. An especially fine variety for borders and excellent for pot culture. Should not be forced hard. Must be planted early. Height I $_{5}$ inches. 15 cts. each, $\$ 1.50$ per doz., $\$ 12$ per 100 .
Glory of Noordwijk. B. One of the best and most attractive of the Bicolors; perianth sulphur-white, trumpet chrome-yellow, very long and elegantly reflexed at the brim; a flower of good size and great substance. Grand for pots or cutting. Height I 4 inches. 40 cts. each, $\$ 4$ per doz., \$30 per 100.

Golden Spur. A. One of the grandest, with extra-large, bold, striking. It is of unusually robust habit and unsurpassed for gardens, pots or forcing. Early and extremely free-flowering.

Jumbo buz. To0 1,000

Jumbo bulbs ................ \$o $75 \quad \$ 5$ oo $\$ 40$ oo

Mammoth buibs................. 50 , 3 oo 2500

First size................... $35 \quad 2$ oo 1500 Grace Darling. B. Gracefully twisted white perianth, trumformed flower, excellent for border planting or for forcing. A variety that has been much admired and that looked very pleasing to our representative in the fields this spring. Height 18 inches. 20 cts. each, $\$ 2$ per doz., $\$ 15$ per 100.

Henry Irving. A. Perianth clear yellow, broad and spreading; deep yellow trumpet, large and wide at the mouth; splendid; early. For forcing or the border. 5 cts. each, 40 cts. per doz., $\$ 3$ per $100, \$ 25$ per 1,000 . 
GLANT TRUMPET NARCISSI, continued

King Alfred. A king among the newer varieties, forcing and that responds splendidly to pans or pots for exhibition, its size, general vigor and depth of color puts it in a distinct class of the Finest Giant Golden Yellow Narcissus. The illustration on the front cover gives but a faint idea of its magnificence, although it shows the form well. (For fuller description and price, see page I7.)

Mrs. Thompson. B. Creamy white perianth, Irs. Thompson. pale lemon trumpet passing into white, elegantly frilled; one of the best growers among white 1rumpets, and a free-bloomer. Fine for the border and for early forcing. Height I5 inches. 5 cts. each, 50 cts. per doz., $\$ 3.50$ per 100, $\$ 30$ per 1,000 .

Obvallaris (The Tenby Daffodil). A deep yellow self-color; broad, round petals, with rather short trumpet; very aistinct. Fine for borders and excellent when grown in pots. Height I 2 inches. 5 cts. each, 40 cts. per doz., $\$ 3$ per 100 , $\$ 25$ per 1,000 .

Princeps. A. Very early. This is one of the most rinceps. popular winter-flowering and forcing varieties grown. Flowers large; perianth sulphuryellow; immense, rich yellow trumpet. 5 cts. each, 30 cts. per doz., $\$ 2$ per $100, \$ 15$ per 1,000 .

Queen of Spain. A very graceful and quite a Queen of Spain. distinct variety of the Triandrus type; trumpet of uniform soft yellow, with a very reflexed perianth, making the flower very dainty and unique looking. Excellent for borders and naturalizing in woodland. Height 12 inches. 10 cts. each, \$1 per doz., \$7.50 per 100 .

Trumpet Major. A. Flower large and almost of rumpet Major. a uniform deep golden. Highly prized as an early forcing sort and largely planted $\begin{array}{ccccc}\text { for outside bedding. Each } & \text { Doz. } & \text { I00 } & \text { I,000 } \\ \text { Dutch-grown..... \$o } 05 & \$ 0 ~ 30 & \$ 200 & \$ 1500\end{array}$

French-grown (for

forcing only).... $05 \quad 40 \quad 300 \quad 2000$

Vanilla. Sweet-scented. A variety that has made anilla. rapid strides for popular favor. A very large, beautiful bold flower; trumpet deep yellow with a paler perianth. (For fuller description and price, see page I 7.)

Victoria. B. A Bicolor famous for its large and durable flowers, which stand boldly erect; broad perianth of creamy white; large, broad, fluted trumpet of rich yellow. A strong grower, with massive flowers. Fine for forcing, the flowers lasting in excellent condition long after being cut.

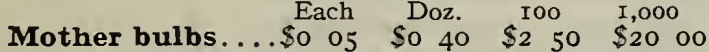

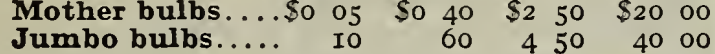

William Goldring. C. White perianth, droopWillam Goldring. ing over a long trumpet; trumpet soft primrose passing to white. A very graceful flower whose drooping habit has brought it the common name of Swan's Neck. An extremely satisfactory variety for border or pot culture. Height I 5 inches. 5 cts. each, 40 cts. per doz., \$3 per $100, \$ 25$ per 1,000 .

\section{GIANT TRUMPETS IN MIXTURE}

\section{(For Naturalizing)}

Each year we import large quantities of these bulbs for naturalizing, and frequently, at the end of the season, prepare a mixture of some of the best varieties, which we have in surplus, for this purpose, which we offer at a very low price of

$\$ 1.25$ per $100, \$ 12.50$ per $1,000, \$ 50$ for 5,000

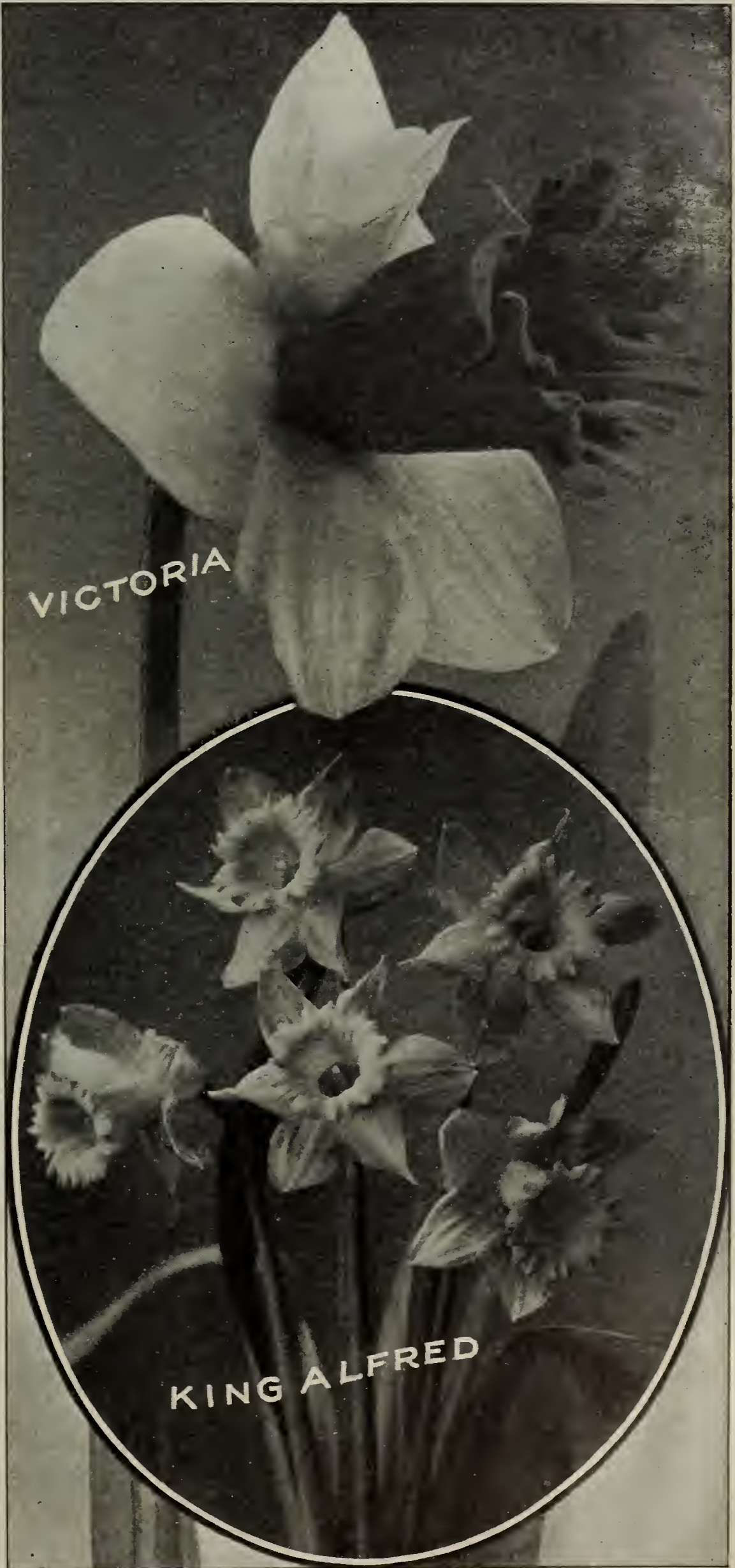




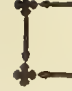

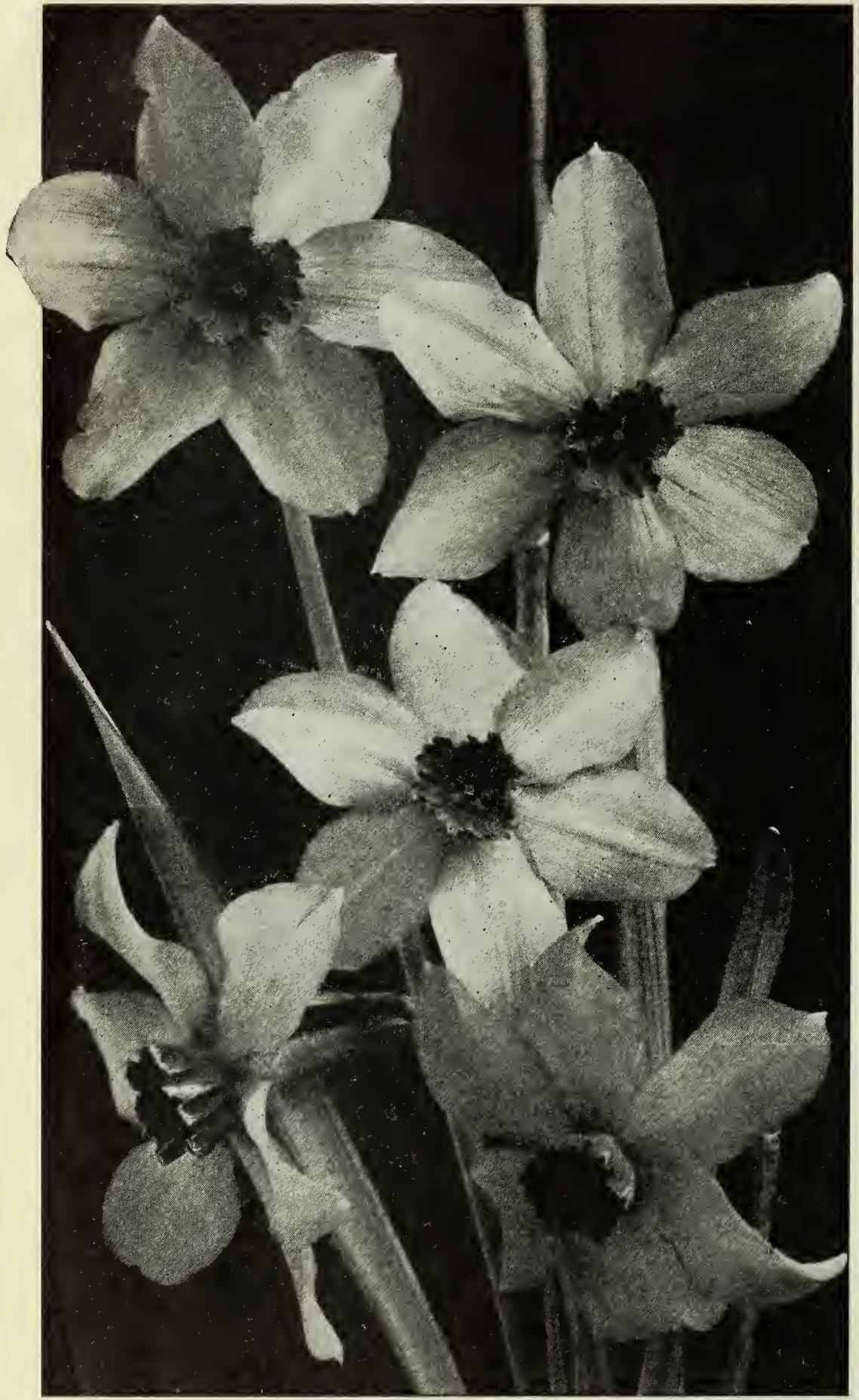

Conspicuus Narcissi

\section{Medium Trumpets in Mixture (For Naturalizing)}

Our mixture of these Medium Trumpets for natural plantations contains a great many varieties which we do not list under separate headings, and are excellent for this purpose.

$\$ 1.25$ per $100, \$ 10$ per $1,000, \$ 40$ for 5,000
THE GROWN or CUP NARCISSI

Autocrat (Incomparabilis). C. Clear golden yellow Aroad perianth tending to reflex, cup widely expanded at the mouth. A very handsome variety for the border or pots. Height 20 inches. 3 cts. each, 30 cts. per doz., \$2 per 100, \$15 per 1,000.

Beatrice (Leedsii). Beautiful, snowy white; one of the prettiest of new Leedsii type. Forms a charming contrast with the yellow sorts and is very effective when planted in a solid bed. 8 cts. each, 50 cts. per doz., $\$ 3.50$ per $100, \$ 30$ per 1,000 .

Conspicuus (Barrii). D. Large, broad, spreading Conspicuus perianth of soft yellow; short yellow cup edged bright orange-scarlet; a fine, large flower; one of the handsomest of all. Splendid for the border or midseason forcing. 3 cts. each, 25 cts. per doz., $\$ 1.50$ per 100 , $\$ 12$ per 1,000 .

Cynosure (Incomparabilis). C. Large; pale primrose perianth, passing into white; yellow cup naturalizing. Height , showy variety for the 3 cts. each, 30 cts. per doz., \$2 per 100, \$12 per 1,000.

Duchess of Brabant (Leedsii). Elegant; pure yellow cup. Height 15 inches, 3 cts. doz., \$2 per 100, \$15 per 1,000.

Katherine Spurrell (Leedsii). D. A grand new variety; flowers of large size beautiful form and splendid substance; broad, overlapping perianth of snow-white and a delicate canary-colore crown. An especially fine cut-flower. 6 cts. each, 65 cts. per doz., \$5 per 100 .

Leedsii alba. Silvery white, crown pale primrose dainty Height passing off to white; charming and $\$ 1.75$ per 100, $\$ 15$ per 1,000 .

Mrs. Langtry (Leedsii). D. A remarkably freeproducing several flowers; broad, white perianth, and white cup opening pale primrose. On account of its low price it is largely used for naturalizing. It is good, also, for potting, as it blooms so profusely in the house in winter. 3 cts. each, 25 cts. per doz., $\$ 1.50$ per $100, \$ 10$ per 1,000 .

Queen Bess (Incomparabilis). A. Perianth white; Queen Bess large, well-expanded cup of light yellow. An early variety of value for pot culture, and good for bedding. Height I5 inches. 3 cts. each, 30 cts. per doz., \$2 per 100, \$15 per 1,000.

Sir Watkins (Incomparabilis). (Giant Chalice Flower, or Big Welshman). A gigantic variety; immense, long-stemmed flowers, sometimes measuring $5 \mathrm{I} / 2$ inches across, being the largest variety grown; rich, light yellow, with a very large, dark cup tinted with orange. Fine for large beds. Height 2 I inches. Jumbo bulbs, 5 cts. each, 40 cts. per doz., $\$ 3$ per $100, \$ 25$ per 1,000 .

Stella (Incomparabilis). Perianth white; bright yelLella low cup, very beautiful; a bold flower for the border and equally good for pots. Height I9 inches. 5 cts. each, 35 cts. per doz., $\$ 2$ per $100, \$ 15$ per 1,000 .

\section{HOOP PETTICOAT NARCISSI}

Bulbocodium citrinum. One of the quaintest of the famaccount of its slender grace. The flowers are pale yellow, in the form of an inflated skirt. Height 6 inches. 5 cts. each, 40 cts. per doz., $\$ 3$ per 100.

Bulbocodium monophyllum. Similar to the preceding, (he flowers are white. Graceful, dainty and sweet. Height 6 inches. 5 cts. each, 50 cts. per doz., \$4 per 100. 


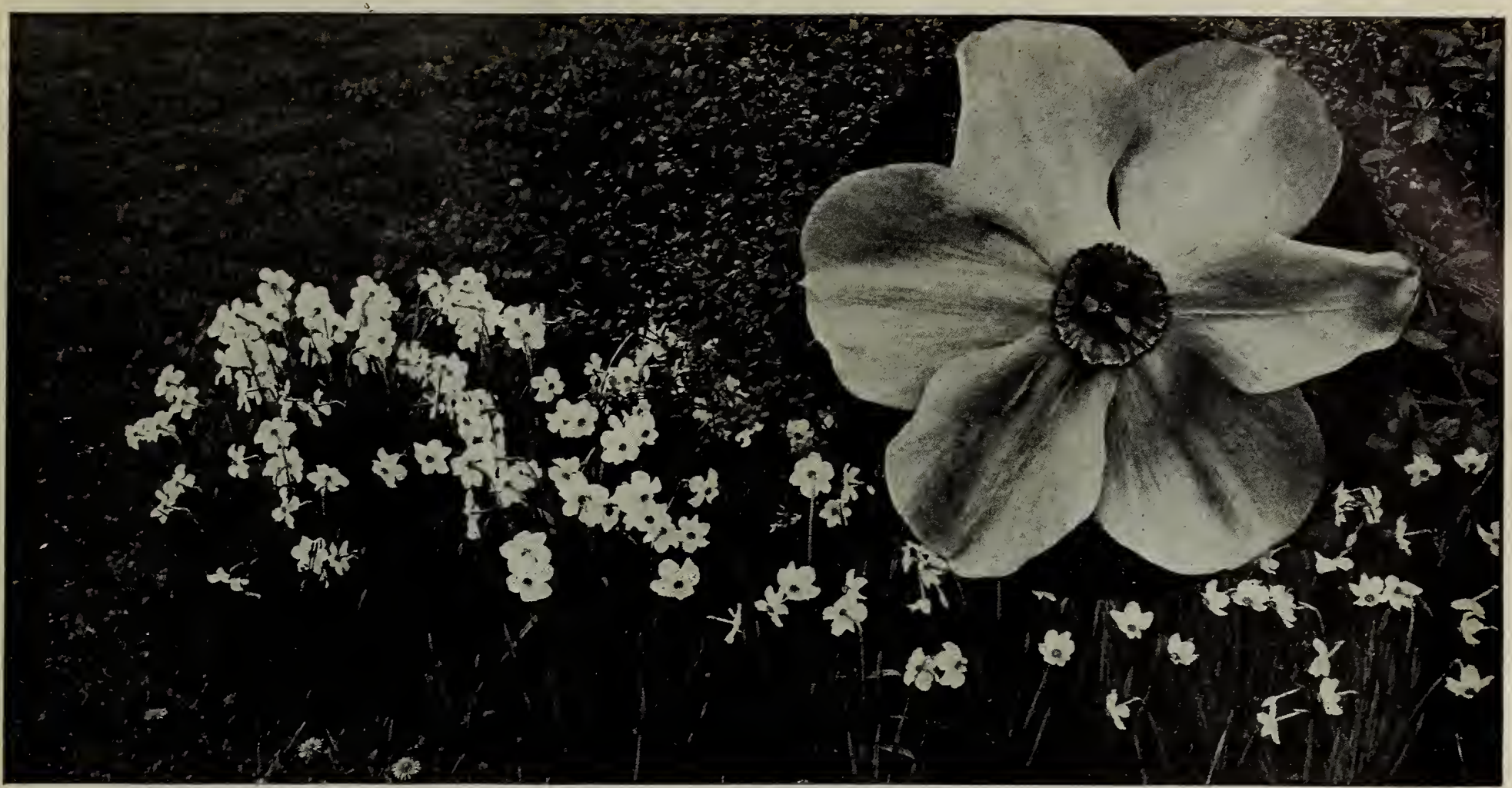

Narcissus Poeticus, Naturalized

\section{THE POPULAR POET'S NARGISSUS $\begin{gathered}\text { (Narcissus } \\ \text { poeticus) }\end{gathered}$}

This class of Narcissus, instead of having a trumpet or crown, has a small, wide-mouthed cup. They are very hardy, and are used in large numbers, for naturalizing, their simplicity of form and delightful fragrance making them highly prized. The varieties Ornatus, King Edward VII and Grandiflorus are used with excellent success for forcing.

POETICUS (Pheasant's Eye). E. The original late-flowering Pheasant's Eye variety so popular for gardens and naturalizing; pure white flowers with orange cup, edged with red. Height I5 inches. 25 cts. per doz., \$1 per 100, $\$ 7.50$ per I,000.

POETICUS ORNATUS (Improved Poeticus). D. Grand flower for cutting. Larger and more symmetrical than the old variety and considerably earlier. Pure white flowers, saffron cup, tinged rosy scarlet. Magnificent cut-flower. 5 cts. each, 25 cts. per doz., \$I.50 per IOO, \$1 2.50 per I, 000.

POETICUS, KING EDWARD VII. D. A new and magnificent large-flowering, early variety, with broad, round, white flower of great substance, and yellow cup edged deep red. 75 cts. per doz., $\$ 4$ per I00, $\$ 35$ per 1,000 .

POETICUS GRANDIFLORUS. C. A new and large type of the late-flowering Poeticus; very large and handsome flowers; pure white with yellow cup suffused with crimson. $60 \mathrm{cts}$. per doz., \$3 per I00, $\$ 25$ per I,000.

BIFLORUS (Peerless). C. Pure white, with yellow cup, bearing two flowers on a stem. Fine for cutting. $20 \mathrm{cts}$. per doz., \$I per I00, $\$ 8$ per I,000.

BURBIDGEI. C. Pure white, yellow cup, edged scarlet. $20 \mathrm{cts}$. per doz., \$I per Ioo, $\$ 7$ per I,000.

\section{Narcissus Poetaz}

\section{THE HARDY CLUSTER-FLOWERED NARCISSI}

These new hybrids between Poeticus and Polyanthus are hardy, healthy, strong growers, some of the varieties attaining the height of 2 feet. The Poeticus-like flowers are borne in clusters like those of the Polyanthus type. As a border, particularly when edged with Grape Hyacinth, Heavenly Blue, they prove very effective and will become permanent. Excellent for pots, also.

ALSACE. C. Pure white, with yellow cup, having a slight reddish edge when newly opened; broad, large flowers, usually four to a stem. 50 cts. per doz., $\$ 3.50$ per I00, $\$ 32.50$ per I,000.

IRENE. D. Yellow perianth with deep golden yellow cup; broad flowers borne seven to eight on a stem; three stems to a bulb. The largest yellow. $60 \mathrm{cts}$. per doz., $\$ 4.50$ per I00, $\$ 40$ per I, 000 .
ELVIRA. D. A large flower of remarkable substance, three to four borne on long stems, two and three stems to a bulb; fine for cutting; color pure white, with yellow cup; strong grower and free flowering fragrance distinct, resembling that of Gardenia. Height 24 inches. 40 cts. per doz., $\$ 3$ per I00, $\$ 25$ per I,000.

If wanted by mail, add 5 cts. per doz. for postage

\section{Narcissus Jonquilla (Jonquils)}

Very much prized for their charming golden and deliciously sweet-scented flowers, perfectly hardy, and flowering very early in the spring. They are also admirably adapted for winter forcing.

SINGLE JONQUIL. E. The well-known favorite, delicately scented and beautiful for forcing. Rich yellow; very fragrant. I5 cts. per doz., 75 cts. per Ioo.

DOUBLE JONQUIL. B. Heads of small, but very double deep golden yellow flowers; powerfully scented and good for forcing. 5 cts. each, 35 cts. per doz., $\$ 2.50$ per 100.

If wanted by mail, add 5 cts. per doz. 10 postage
ODORUS RUGULOSUS. A great improvement on the common Single Campernelle Jonquil. Flowers deep yellow and twice the size; four to six flowers on a stem; splendid odor. $40 \mathrm{cts}$. per doz. $\$ 2.50$ per 100 .

CAMPERNELLE, DOUBLE. A very free-flowering sort of the Single Jonquil; flowers deep yellow, double; three to four on a stem. $30 \mathrm{cts}$. per doz., $\$ 2$ per Ioo. 


\section{Polyanthus Narcissi}

A very decorative class of bulbous plants for greenhouse and window-garden. They produce large trusses of bloom and are quite fragrant. These bulbs are not hardy and should not be planted nutdoors north of the Carolinas. There are hardly any of the Narcissi that respond to forcing so easily and quickly, and a large number of florists frequently have them in bloom from November until Easter. The variety Paper-White can be grown in water, with pebbles in shallow dishes or bowls, the same as the Sacred Chinese Narcissus.

\section{GIANT PAPER-WHITE NARGISSI}

This large-flowering Paper-White Narcissus is such an improvement over the ordinary Paper-White that we have decided to discontinue the sale of the latter. It can be had in bloom from Christmas to Easter. Plant bulbs in shallow boxes or pots so that they almost touch each other, and store in a cool cellar or shed until rooted. By bringing into the light during early November they may be had in bloom for Christmas. Excellent results can be obtained by growing in bowls of water and pebbles or moss.

Jumbo Bulbs.

Each Doz. $100 \quad \mathbf{x}, 000$

Bazelmann major. Large flowers in immense clusters; broad, pure white perianth, large, dark yellow cup. One of the finest Polyanthus Narcissi in cultivation. Io cts. each, 85 cts. per doz., $\$ 6.50$ per 100, $\$ 60$ per I,000.

Double Roman. White perianth, with double orange-yellow cups. Largely forced during winter as a cut-flower. $5 \mathrm{cts}$. each, $30 \mathrm{cts}$. per doz., $\$ 2$ per 100, $\$ 17.50$ per I, 000 .

Grand Monarque. Purest white flowers of the largest size, with canary-yellow cups; immense trusses of bloom. Selected Bulbs, $5 \mathrm{cts}$. each, $40 \mathrm{cts}$. per doz., $\$ 3.50$ per I00, $\$ 30$ per I,000.

Grand Soleil d'Or. Rich yellow, reddish orange cup. Excellent for bedding. 5 cts. each, 40 cts. per doz., $\$ 3$ per I00, $\$ 25$ per I,000.

Lord Canning. Clusters of large, golden yellow flowers, with orange cups. Io cts. each, $75 \mathrm{cts}$. per doz., $\$ 6$ per I00, $\$ 50$ per I,000.

Mont Cenis. Broad, round, overlapping petals of white, and large, rich yellow cup; of compact, sturdy growth; immense clusters of bloom. Io cts. each, 75 cts. per doz., $\$ 5$ per I00, $\$ 45$ per I,000.

Staten General. Clusters of white flowers, with citron-colored cups. 5 cts. each, 50 cts. per doz., $\$ 3$ per I0o, $\$ 25$ per I,00o.

White Pearl. Extra-fine clusters of satiny white flowers, citroncolored cups; profuse bloomer. Io cts. each, 75 cts. per doz., $\$ 5$ per IOO, $\$ 45$ per I, 000.

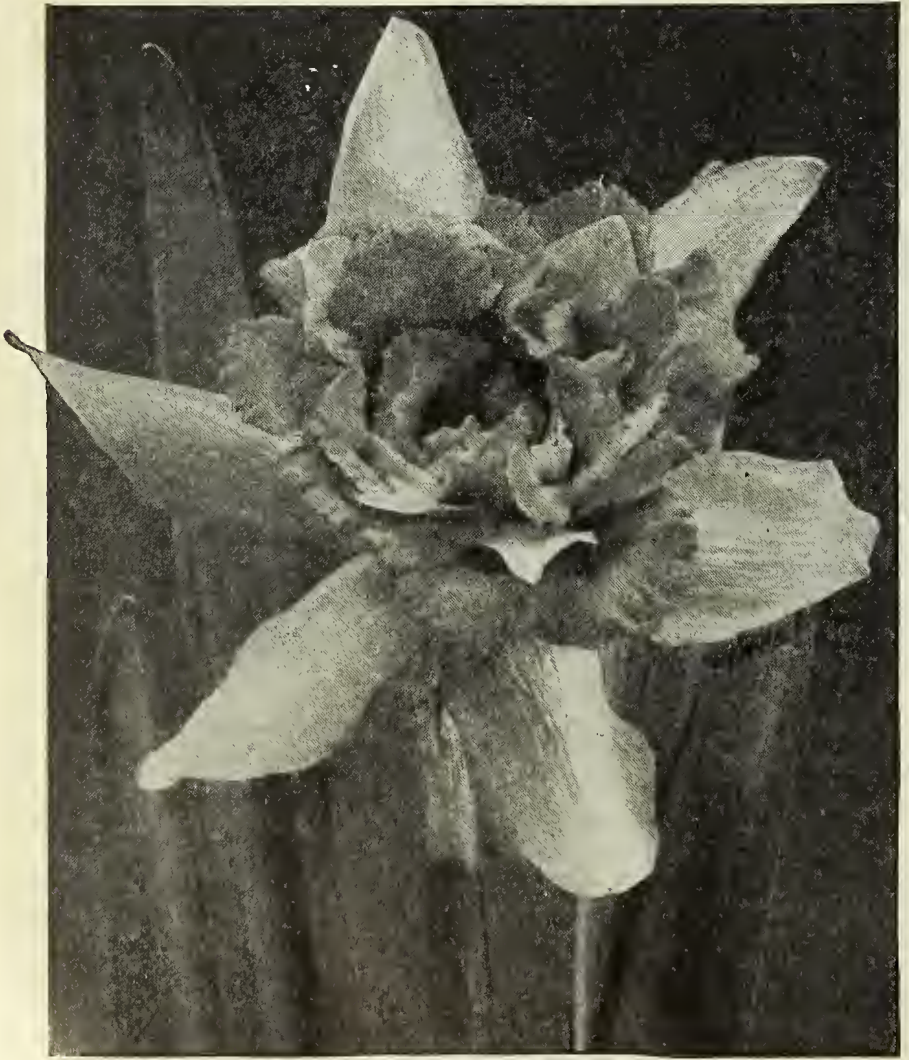

Van Sion Narcissus

\section{GHINESE SAGRED NARCISSUS}

JOSS FLOWER, or ORIENTAL NEW YEAR'S LILY

Can be grown in pots, but are raised more satisfactorily in bowls filled with pebbles and water. Flowers white with yellow cup. Io cts. each, $\$$ I per doz., $\$ 7.50$ per Ioo; Mammoth Bulbs, I5 cts. each, $\$$ I.50 per doz., $\$$ Io per Ioo; buyer pays transit.

\section{Double Narcissi (Daffodils)}

The Double Narcissi, generally termed Daffodils, are used in large quantities by the commercial florists for forcing in pots, pans or flats for cutting. They are as hardy as rocks, and when "naturalized" increase in number and splendor each year.

\section{VAN SION NARCISSI}

This, the most popular of the double Narcissi, is famous as the Old Double Yellow Daffodil. Rich golden yellow perianth and trumpet. One of the best forcing sorts, immense quantities being grown for this purpose in Europe and America.

S. \& W. Co.'s Exhibition Grade. This grade of Double Van us from the very largest double-nosed bulbs, and are what is termed top-roots. Our large importations of this variety makes it possible for us to secure this very fine grade of bulbs. Three bulbs planted in an 8 inch bulb-pan make an excellent show, and give four to five strong and perfect blooms.

Jambo Exhibition Grade. Each Doz. 100 r,000

Mammoth Double-Nose. Will produce two to three fine flowers............ fine flower... flowered Daffodil). Double, snow-white, gardenia-like flowers, exquisitely scented. 5 cts. each, 25 cts. per doz., \$I.50 per Ioo.

Incomparable fl. pl. (Butter and Eggs). Full-double flowers of rich yellow, with orange nectary. Splendid variety for either forcing for winter cut-flowers or for open-ground planting. $5 \mathrm{cts}$. each, $20 \mathrm{cts}$. per doz., \$I.25 per IOo.

Orange Phonix (Eggs and Bacon). Beautiful, double, white flowers, with orange nectary. Splendid for pot culture and cutting and for garden decoration. 5 cts. each, 40 cts. per doz., $\$ 3$ per Ioo.

Sulphur (or Silver) Phœnix (Codlins and Cream). Large, creamy white flowers, sulphur nectary. Exquisite corsage flower; fine for growing in pots. Io cts. each, 75 cts. per doz., $\$ 4$ per Ioo.

Mixed Double Narcissi. Plant liberally of these for cutting purposes or for naturalizing. $5 \mathrm{cts}$. each, $25 \mathrm{cts}$. per doz., \$I.25 per Ioo. If wanted by'mail, add $10 \mathrm{cts}$. per doz. to cover postage 


\section{Freesia, Purity}

ORIGINAL STOCK GREENHOUSE-GROWN

Our stock of this Freesia is again ready for distribution. Our bulbs have been grown by Freesia specialist, and our customers can rest assured that the stock is absolutely true.

\section{Read What Florist Review says May 25, 1911}

\section{PURITY FREESIA IS MUCH SUPERIOR TO THE ORDINARY REFRACTA ALBA}

"Purity is unquestionably the finest of all Freesias, and is eagerly bought in the flower markets in all parts of the country. The plants illustrated were grown by William Nicholson, Framingham, Mass., well-known as a leading carnationist, and are in ro-inch pans. A 24-inch rule is seen standing alongside one pan, the plants in which are 28 inches in height from the top of the pan. Freesias such as these have commanded a fancy price in the Boston market, the first being cut the week before Christmas. Unlike some growers, Mr. Nicholson believes in planting the bulbs quite thickly, and finds he gets excellent results from growing fifty bulbs in a Io-inch pan, the spikes being just as good as when half that number are grown.

"The bulbs, after planting, are stood in coldframes and left there until early 'mums or other crops are out of the way. They are then given shelves well up to the light. In a coolhouse, kept around 45 degrees, the flowers are finer and possess greater substance than when grown warmer. A great mistake is still made by many in Freesia culture in placing the bulbs in heat at once after planting. They should be grown as cool as possible in the earlier stages. Freesias with stems such as Mr. Nicholson's can be arranged magnificently in vases, being preferred by many critical buyers to both roses and carnations. The bulbs from which these fine Freesias were grown came from William M. Matthews, Great Neck, L. I., a grower for Stumpp \& Walter Co."

Purity, True (Greenhouse-grown)- Doz. I00 I,000 MaMnoth Size..................\$o 75 \$4 50 \$40 oo FIRSt SizE................... 60 $350 \quad 3000$

\section{REFRACTA ALBA-}

JUMBO BULBS

MAMMOTH BulbS

FIRST SizE

$\begin{array}{lllll}40 & 2 & 25 & 20 & 00 \\ 25 & \text { I } & 75 & \text { I } 5 & 00 \\ 15 & \text { I } & 25 & \text { I0 } & \text { 00 }\end{array}$

SNOWSTORM. A distinct and greatly improved type, producing large sprays of pure snow-white flowers. Foliage less coarse than

Purity, Top root ...........

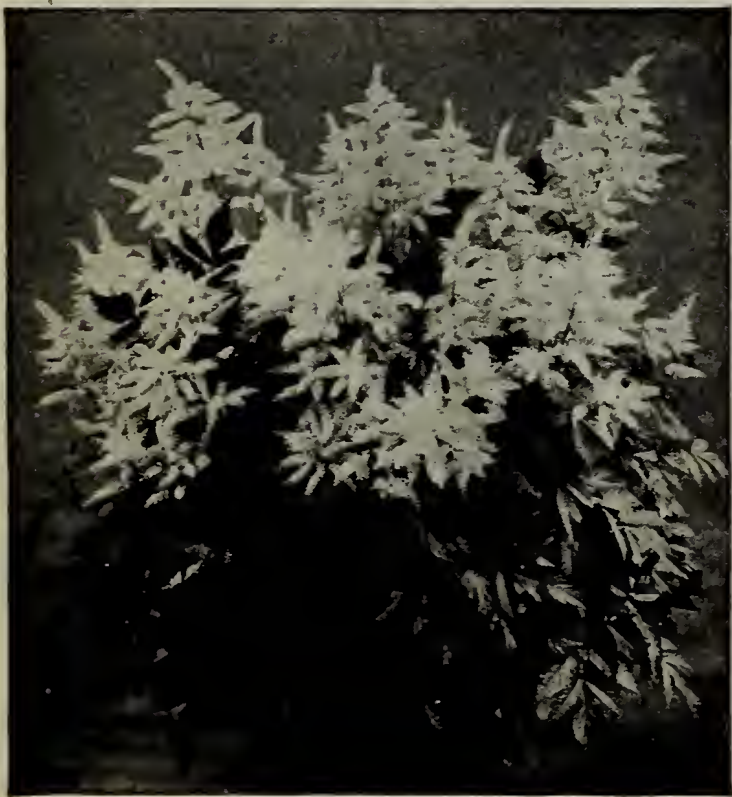

$35 \quad 250 \cdot 2000$

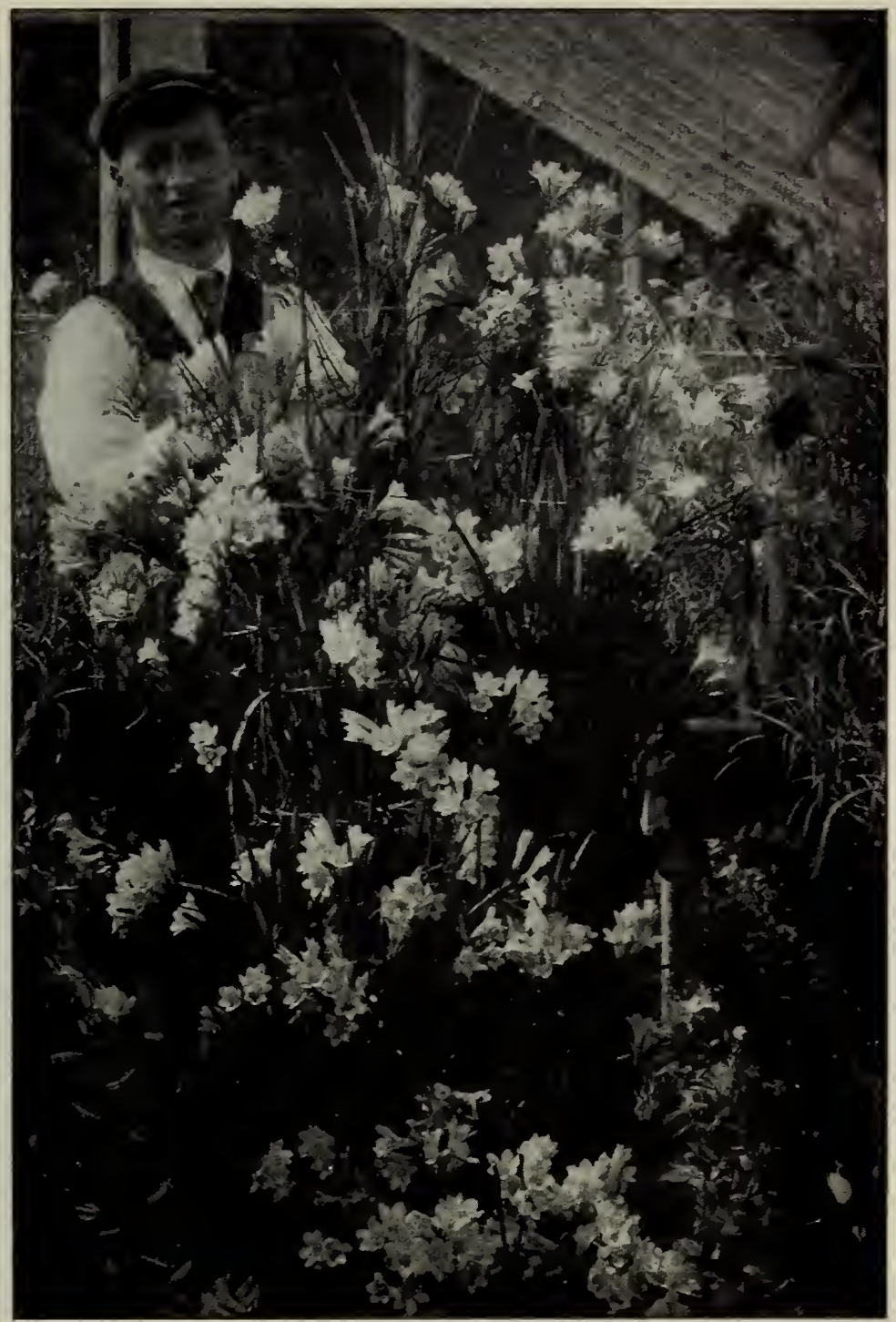

Freesia, Purity

\section{Spiræa}

Arrive in November

For conservatory or window-garden decoration there is no better subject. Are frequently planted out, and flower during spring. They are extensively grown by florists as an Easter plant. Pot upon arrival and store in cool cellar or coldframe until two months before you wish to have them in bloom.

\section{PEACH BLOSSOM SPIRAA}

A novelty of sterling merit; color delicate soft pink: habit and growth similar to Gladstone.

25 cts. each, $\$ 2.25$ per doz., \$16 per roo

Japonica. A variety grown to a large extent on account of Each Doz. Ioo its good forcing qualities.

Astilboides floribunda. A very strong grower, producing large, pure white plumes.

Compacta multiflora. Compact, dwarf variety \$o I5 \$I 50 \$I2 o0

\section{Compacta multiflora. Compact, dwarf variety...}

I5 I 50 I2 00

on stems $\mathrm{I} 1 / 2$ feet high; foliage excellent...

Queen Alexandra. Shrimp-pink; a variety with dense, compact spikes. The plants are very attractive..
$25 \quad 200 \quad 1400$

$25 \quad 225 \quad 16$ o0
Spiræa, Peach Blossom

WE STRONGLY ADVISE THOSE WHO HAVE NOT GIVEN OUR PURITY FREESIA A TRIAL TO TRY 50 OR IOO FOR COMPARISON 


\section{HARDY LILIES}

We especially recommend deep planting, say, from 6 to 10 inches; varieties like Speciosums require at least 10 inches, with an ample amount of sand beneath the bulb to insure proper drainage. Cover the beds with leaves or litter during winter. Lilies thrive well in borders, formal gardens or shrubbery, and usually flower at a time when the shrubbery has ceased blooming, adding increased interest. The following varieties have proven to be sorts that may be planted in the fall or spring time with excellent results. We frequently receive orders for Lilium candidum for spring delivery. This Lily arrives in our country from France in August and must be planted by October I.

\section{Lilium auratum}

(Golden-Rayed Lily of Japan)

The flowers are pure white, thickly studded with crimson spots, while through the center of each petal runs a clear golden band. Fully expanded, the flowers measure nearly a foot across, are produced abundantly from June to October, and possess a most delicious fragrance. 3 to 5 feet.

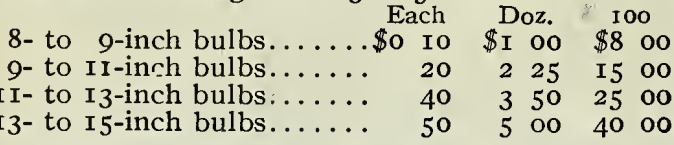

\section{Lilium speciosum magnificum}

This Speciosum Lily is an improvement on Rubrum, Roseum or Melpomene, and is a most excellent flower for forcing in the conservatory or greenhouse and for planting out. It is of more robust habit than Rubrum, Roseum or Melpomene and a freer bloomer, its color being a rich scarlet.

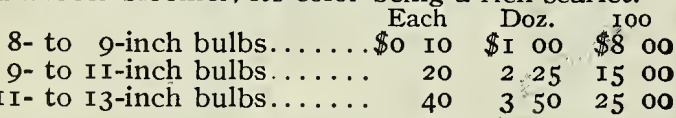

\section{Lilium speciosum album}

The white Speciosum, which is usually grown with Magnificum and Lilium auratum, is a very dainty Lily. It flowers outside in the border or among Rhododendrons at the same time as Auratum and Magnificum; and is one of the most extensively cultivated varieties.
8- to 9-inch bulbs.

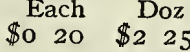
9- to I I-inch bulbs.
$350 \quad 2500$

\section{OTHER HARDY LILIES}

Batemanii. A truly charming Japanese variety, Each growing 3 feet high, with 6 to 8 apricot-colored

flowers on a stem. Blooms in July and August..\$0 $25 \$ 250 \$ 18$ oo

Canadense (Canadian Bellflower Lily). One of the most beautiful native Lilies; flowers bright Elegans bicolor. Bright red, flushed, very Elegans, Painted Chief. Bright flame color.

Elegans Aurora. Deep, rich orange, suffused scarlet.

Elegans, Leonard Jeorg. Rich apricot, spotted; very fine .................................... Henryii. (The Yellow Speciosum.) A new northern China. The plants are of vigorous growth, frequently attaining the height of 6 feet. This Lily is noted for its graceful habit and is an unusually excellent bloomer. Color rich golden yellow, lightly spotted with brown, and in shape guite resembles the Speciosum types.......... I oo lo oo 75 oo Longiflorum. Large, trumpet-shaped blooms of pure white.

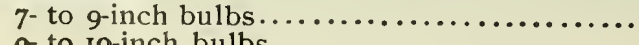

I5

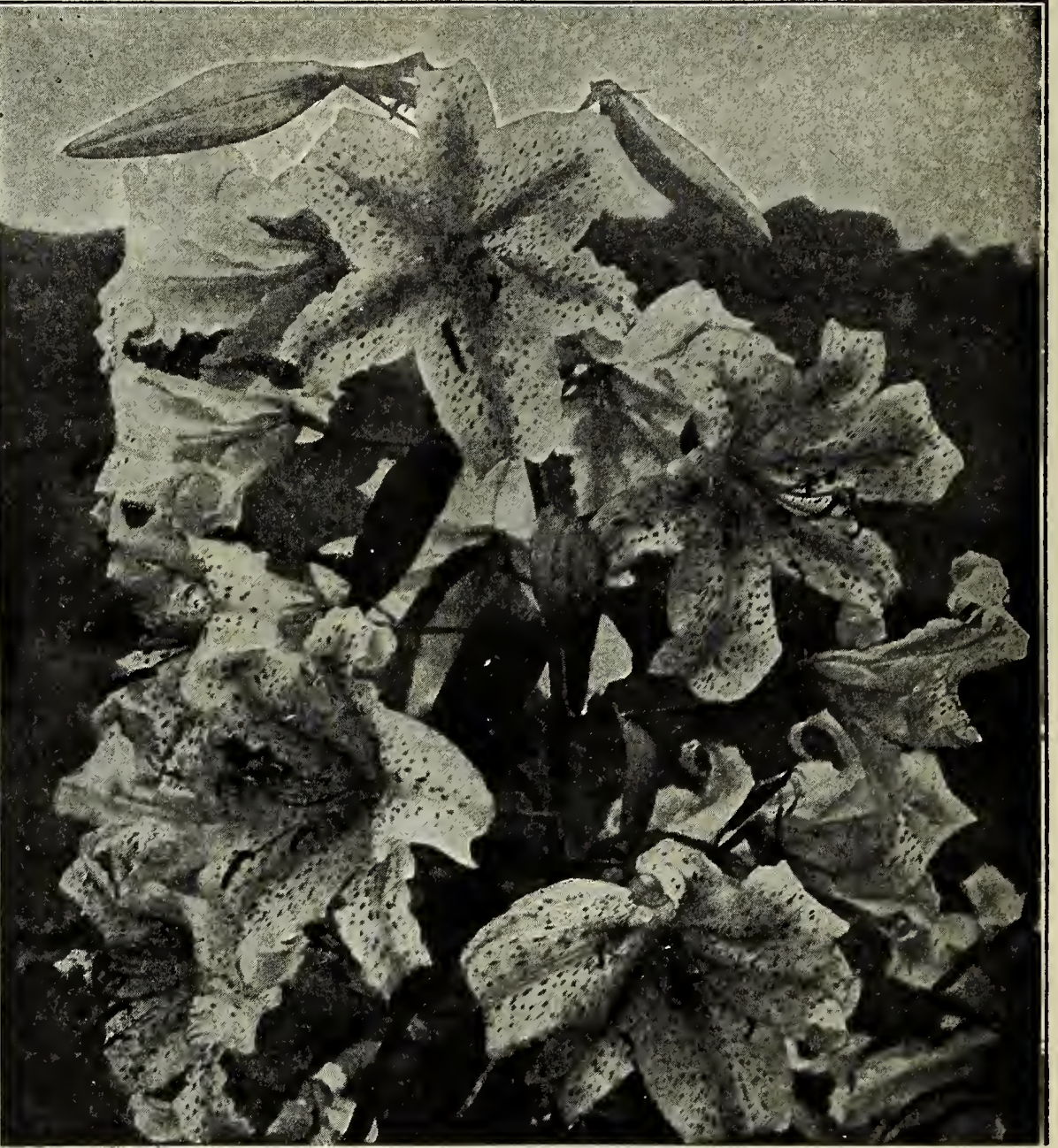

Lilium auratum (Golden-rayed Lily of Japan)

Hansonii Under favorable conditions at-Each Doz. 100 Flowers reddish orange cluster; petals thick and durable; a native of Japan and has always been high in price, but we have a stock of strong, home-grown bulbs that will give splendid satisfaction................... \$0 50 \$5 $00 \quad \$ 4000$

Superbum. In a collection of best plants of all countries, our native Superbum Lily would deserve a first place. In deep, rich soil it often grows 8 feet high, with twenty to thirty flowers. It is of the easiest culture, and may be grown as a wild flower in any swampy or rough part of a place where the grass is not mown. Extra selected bulbs...........................

Tenuifolium. The lovely Coral Lily of Siberia. A great beauty. The brightest of all Lilies. Grows 20 inches high, with finely cut foliage, slender stems and beautiful shaded flowers of a coral-red. One ought to grow them by the dozen, they are so fine for cutting, and making clumps for the lawn. Blooms very early ...............

Tigrinum flore pleno. The Double Tiger Lily. The only double Tiger Lily worth growing ....

Tigrinum splendens. Improved Single Tiger Lily. 8- to ro-inch bulbs ....................

Umbellatum. Somewhat similar in habit to Elegans varieties; flowering in iarge clusters and range in all shades from orange to deep scarlet. Mixed colors......................

Wallacei. Orange-scarlet, spotted with maroon. $3 \mathrm{ft}$. September-blooming ................
I5 I 50 IO 00

I 5 I 50 IO 00

I5 I $50 \quad 1200$

I5 I $25 \quad 800$
I5 I $25 \quad 800$

IO I $00 \quad 700$ 


\section{LILIUM \\ GANDIDUM}

Arrive in August

Sometimes called St. Joseph's Madonna, or Annunciation Lily. One of the most popular and satisfactory of American Garden Lilies. Pure waxy white flowers produced on straight stems, bearing anywhere from ten to thirty blooms of good size and substance; delightfully fragrant. Effective plantings are the result of massing them in clumps or borders. Our bulbs are grown in northern France, where they have a reputation for growing the finest in the world. To insure absolute success, plant the bulbs as early as possible-September preferred. Set bulb about 6 inches deep, and completely envelop with sand. When wanted for forcing, treat similar to Lilium Harrisii.

\begin{tabular}{|c|c|c|c|}
\hline First-Size Bulbs. . & $\begin{array}{l}\text { ach } \\
\text { Io }\end{array}$ & $\begin{array}{l}\text { Doz. } \\
\$ \text { I oo }\end{array}$ & $\begin{array}{c}\text { I00 } \\
\$ 750\end{array}$ \\
\hline Mammoth Bulbs. & I5 & I 50 & 10 00 \\
\hline Jumbo Bulbs... & 25 & 250 & I5 00 \\
\hline
\end{tabular}

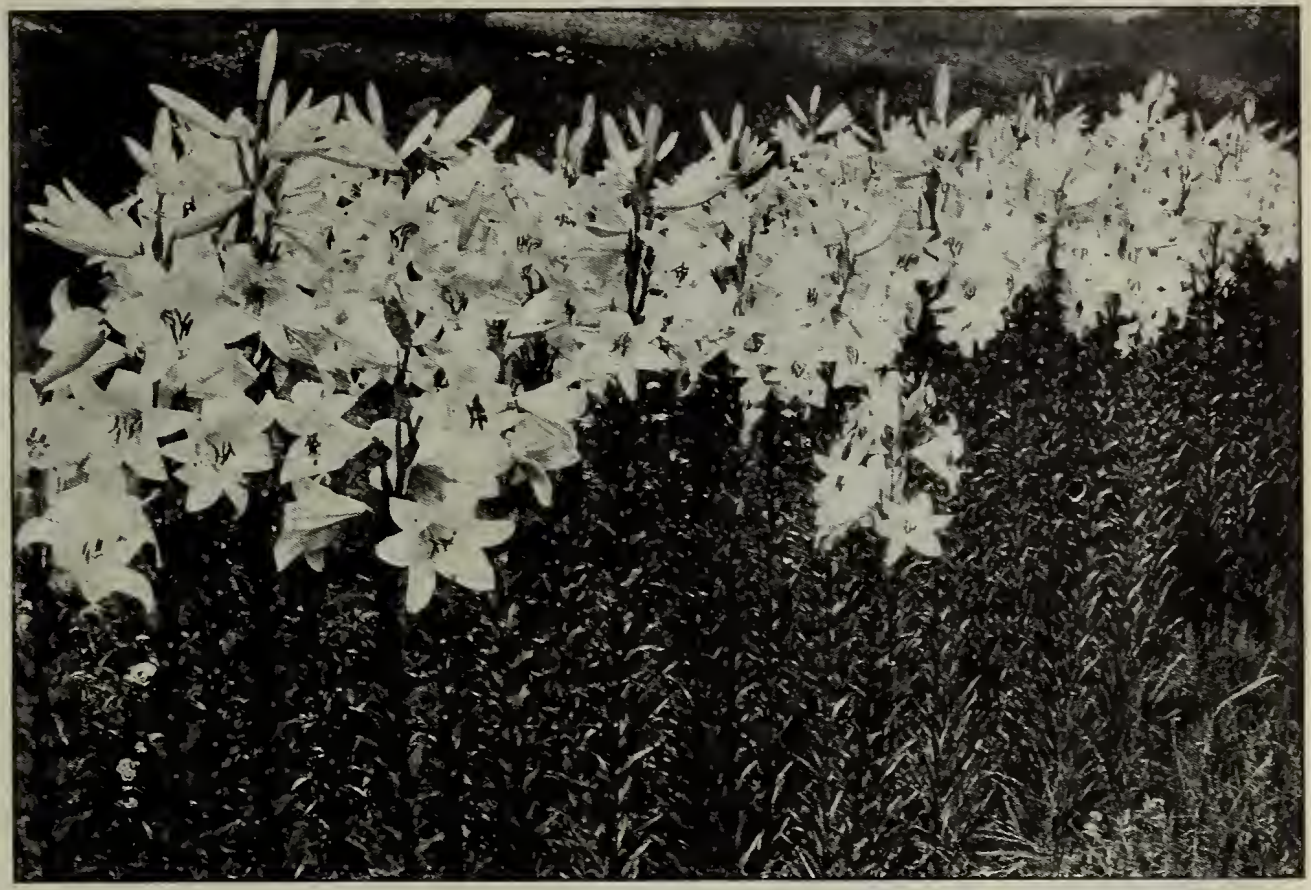

Lilium candidum

\section{Selected Easter Lily Bulbs}

\section{Lilium Harrisii (True Bermuda Easter Lily)}

Cultural Note.-Plant bulbs immediately upon receipt in pots not more than twice their-diameter. Place a handful of welldecayed cow manure in the bottom of the pot, and place bulb on top, and cover with soil; water well and set outside in a pit; cover pot about 3 inches with ashes or soil. When bulbs have become thoroughly rooted, bring inside in a temperature of about 60 degrees under bench. When growth is about 6 inches high, place on bench. About seven weeks before Easter they may be brought into a warmer temperature, and if they have good root development, they can be forced in height and flower slowly; about five weeks from flowering time a slight application of liquid manure each week will benefit them greatly.

\section{S. \& W. Co.'s Selected Stock}

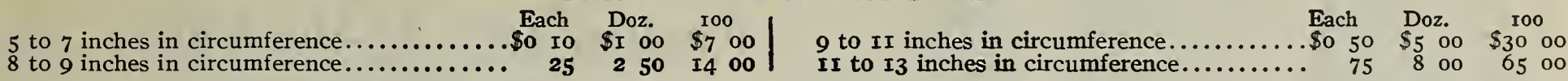

\section{JAPANESE LILY BULBS}

Annually there are imported into this country millions of Lily bulbs from Japan. The florists have them in bloom for every day in the year. Our large importations make it possible for us to get the cream of the selected stock, and we offer to you at best prices the following three varieties of Japanese Lilium longiflorum.

CUlTURAL NOTE.- Upon arrival of bulbs plant, at once in suitable-sized pots, using coarse soft-coal ashes for drainage in the bottom, giving them a soil composed of sandy loam and well enriched with about one-third well-rotted horse or cow manure. ashes.

Put them in a protected place, soak down with water very heavily, and after two or three days cover the pots with 2 or 3 inches of

Place Lilies where they are to bloom after January I, giving them a temperature, as near as possible, of 60 degrees night and 70 degrees day for about ten days, then 70 degrees night and 80 degrees day until buds can all be counted.

During this period, manure-water them regularly once a week with the following liquid: I bushel cow manure (fresh), and one 4-in. pot full of nitrate of soda to each 50 gallons of water.

Spray the foliage once a day (twice a day during clear weather). It is also very important never to allow the soil to get very dry, and never feed unless the soil is moist.

When the buds can be counted easily, move plants where you can get the temperature down gradually, and finally mulch them with either a little sheep manure or bone flour.

\section{Lilium longiflorum multiflorum. S. \& W. Co.'s Select} flowering. Ready in October.

Each Doz. 100

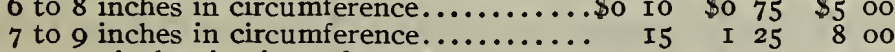

9 to $\mathrm{Io}$ inches in circumference............. 20 20 2 Oo 14 oo

II to 12 inches in circumference......... $30 \quad 2 \quad 502000$

Lilium longiflorum giganteum. Ready in October. This all the year from cold storage. The flowers are large, and it is a variety that may be well recommended. ariety that may be well recommended. Each Doz. Ioo 6 to 8 inches in circumference........... \$o Io $\$ 075 \$ \$ 60$

7 to 9 inches in circumference........... I5 I 50 Io 00

8 to Io inches in circumference.......... $20 \quad 2$ oo I $_{5} 00$

9 to 10 inches in circumference........... 25 2 50 18
Lilium longiflorum formosum. Ready in August. While this Lily has been of uneven height, it has shown a disposition to be a free bloomer. It somewhat resembles the Multiflorum, but blooms earlier.

6 to 8 inches in circumference.

7 to 9 inches in circumference.

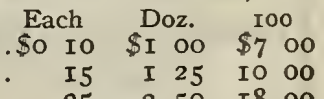

9 to Io inches in circumference.

$25 \quad 2 \quad 50 \quad 18$ oo

\section{Cow or Cattle Manure (Shredded)}

Excellent for use in culture of Lilies; convenient to handle, making it possible to secure this scarce article at all times. I00pound sacks only. I0o lbs. $\$ 2,500$ lbs. $\$ 9, I, 000$ lbs. $\$ 16$, ton $\$ 30$. 


\section{LILY BULBS AND VALLEY PIPS}

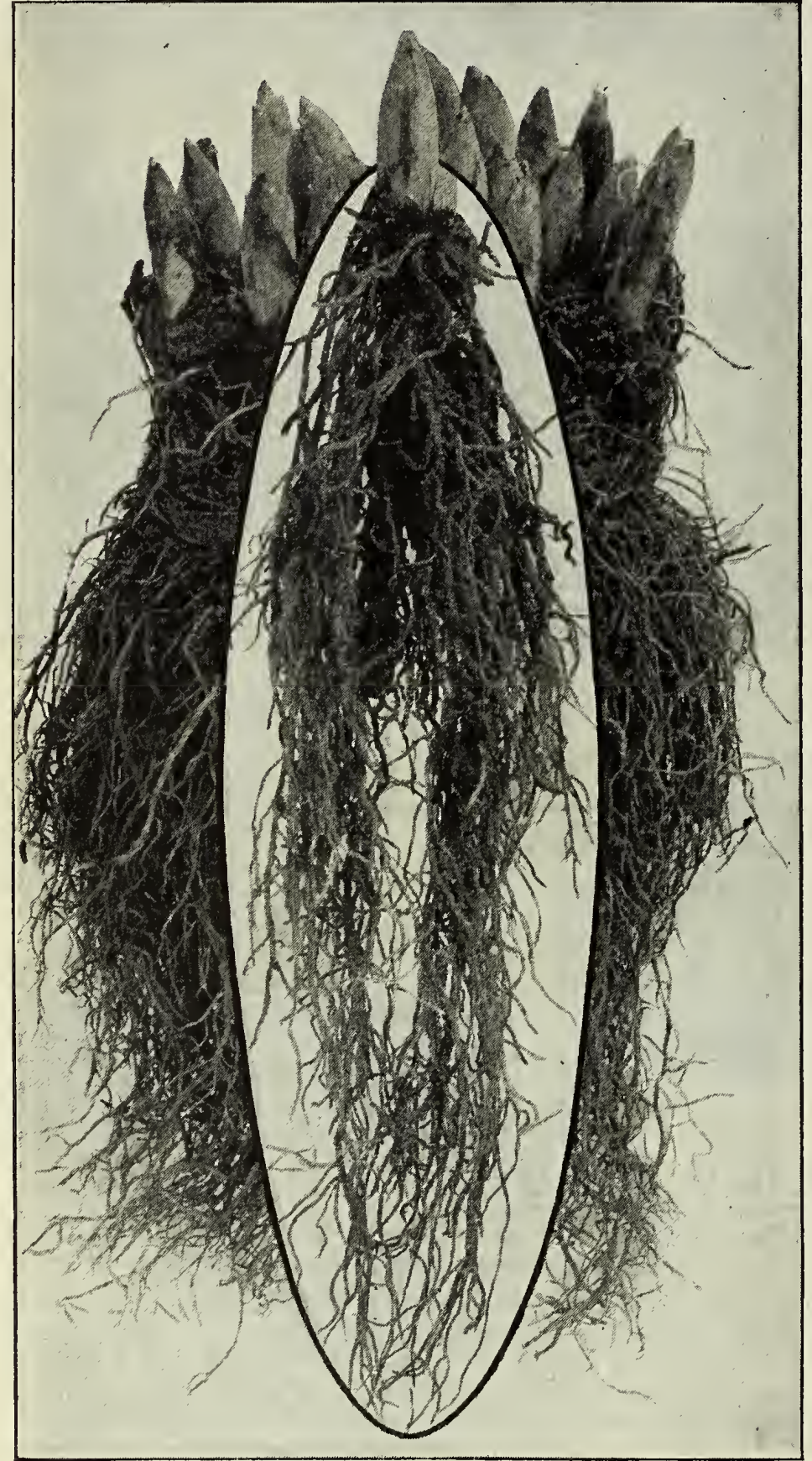

Russian Lily-of-the-Valley Pips

\section{FROM COLD STORAGE}

The following Lilies are repacked (on arrival) and put in cold storage for the convenience of our patrons who desire to have Lilies in bloom throughout the year. Lilium longiflorum giganteum are extensively forced by the florist trade all the year, and can be forced in bloom in four months. Lilium speciosum four to six months. The main point in the culture of Lilies from cold storage is to keep bulbs in a cool place or cellar, after potting, so as to produce the greatest root action before bringing to the light.

LILIUM LONGIFLORUM GIGANTEUM. The Doz. 100 best all-round Longiflorum to force from cold storage.

Io-inch bulbs, repacked, Ioo to case ........\$3 $50 \$ 2500$

LILIUM AURATUM (Golden-rayed Lily of Japan).

The flowers are pure white, thickly studded with crimson spots.

9- to II-inch repacked, I25 to case.............. 3 $00 \quad 200$

II- to I3-inch repacked, 75 to case............. 400 30

LILIUM SPECIOSUM ALBUM. Beautiful pure white.

9- to II-inch bulbs repacked 10o to case.......... $350 \quad 2500$

II- to I3-inch bulbs repacked 75 to case......... 5 o0 3500

LILIUM SPECIOSUM MELPOMENE. R i ch crimson, and very excellent variety for forcing either for Thanksgiving or Christmas.

9- to II-inch bulbs repacked roo to case........ 3 $300 \quad 2000$ I I- to I3-inch bulbs repacked 75 to case......... 4 $400 \quad 300$

LILIUM SPECIOSUM RUBRUM. White ground, suffused and spotted deep pink; a popular and easily forced variety.

9- to II-inch bulbs repacked 100 to case......... 3 $00 \quad 2000$ II- to I3-inch bulbs repacked 75 to case ........ $400 \quad 3000$

\section{$\underline{\text { Russian Lily-of-the-Valley Pips }}$ FROM COLD STORAGE}

\section{THE FINEST VALLEY PIPS OFFERED}

In judging our price of Cold-Storage Russian Lily-of-the-Valley, please remember that the best is the cheapest. Our Valley is positively among the best. Is bought at open prices, with instructions for a selection of the best-developed pips. Our long experience and large importations have commanded this extra selection. Introduced a few years ago, it has now become famous, being forced very extensively by a large number of celebrated Lily-of-the-Valley growers. The Russian Valley produces strong spikes of flowers, about I5 inches in height, bearing from 2 to 20 extra-large pure white bells, which are delightfully fragrant. New crop November delivery, $\$ 2.50$ per 100 , $\$ 20$ per 1,000 . We make a specialty of Lily-of-the-Valley, and are prepared at all times to supply from our cold storage warehouse in original cases of

\begin{tabular}{|c|c|c|c|c|}
\hline $\begin{array}{c}100 \text { S. \& W. Co.'s } \\
\text { Famous Russian Valley } \\
\text { for } \$ 3\end{array}$ & $\begin{array}{c}250 \text { S. \& W. Co.'s } \\
\text { Famous Russian Valley } \\
\text { for } \$ 6.50\end{array}$ & $\begin{array}{c}500 \text { S. \& W. Co.'s } \\
\text { Famous Russian Valley } \\
\text { for } \$ 12\end{array}$ & $\begin{array}{c}1,000 \text { S. \& W. Co.'s } \\
\text { Famous Russian Valley } \\
\text { for } \$ 23\end{array}$ & $\begin{array}{c}\text { 2,000 S. \& W. Co.'s } \\
\text { Famous Russian Valley } \\
\text { for } \$ 44\end{array}$ \\
\hline
\end{tabular}

\section{LILY-OF-THE-VALLEY CLUMPS FOR OUTDOOR PLANTING}

These clumps, planted in the early spring, will flower the same season. Are perfectly hardy and will last forever when once planted. Each clump will produce 25 to 35 sprays of flowers. $35 \mathrm{cts}$. each, $\$ 3.50$ per doz., $\$ 25$ per 100 . 


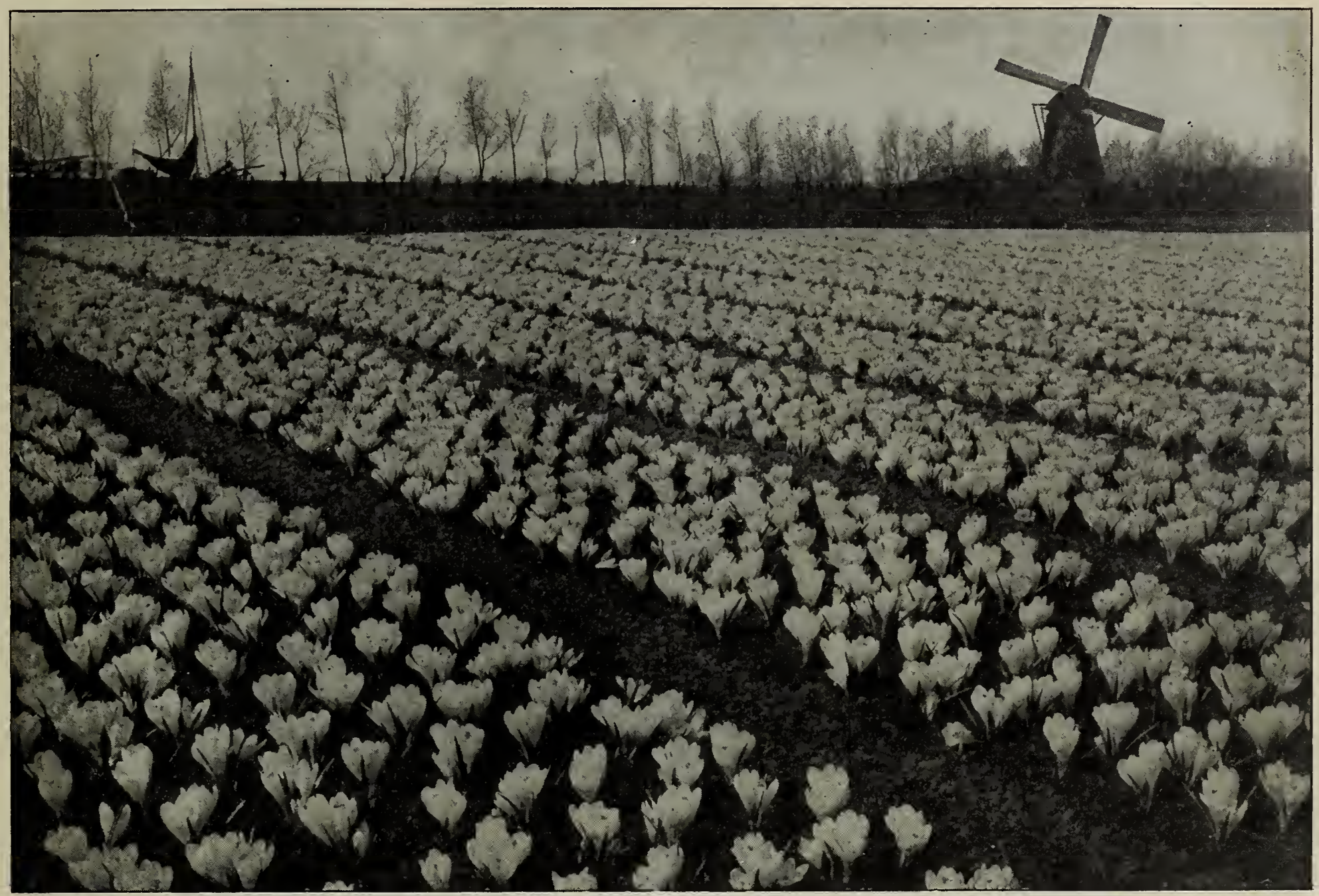

Giant Crocus, Kathleen Parlow

\section{GIANT-FLOWERING GROCUS $\begin{gathered}\text { EXCLLERT FOR } \\ \text { POT CULTURE }\end{gathered}$}

Beauty. Pale lilac, inside soft violet-blue; large and early. A Distinction. Soft reddish violet, a very distinct color among Crocuses. 25c. per doz., \$2 per I00, \$I5 per I,000. Dorothea. Very soft lavender-blue, a fine self-color for pots; not a large flower but makes a fine effect massed in beds. 25 cts. per doz., $\$ 2$ per Ioo, $\$ 15$ per $\mathrm{r}, 000$.
Fantasy. Grayish white ground, heavily striped dark purplish blue; large flower. A striking sort for pot culture or Tar. Kathleen Parlow. $25 \mathrm{cts}$. per doz., \$2 per I00, \$I per I,000. Matador. Dark purple, shaded violet at center; large flower. $25 \mathrm{cts}$. per doz., \$2 per I00, \$I 5 per I,000.

\section{STANDARD NAMED GROGUS}

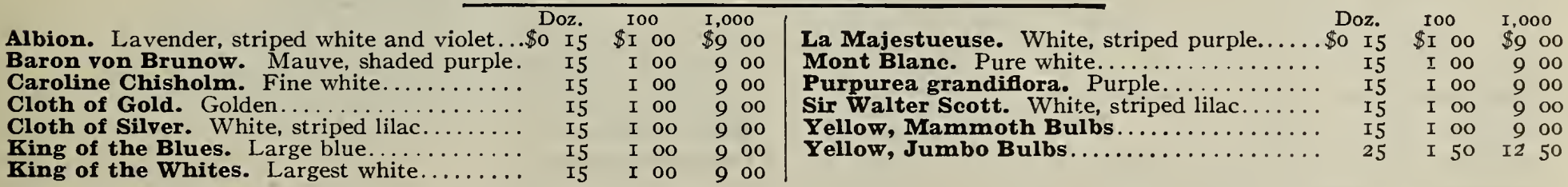

\section{MIXED GROCUS}

Blue, White, Purple, Yellow and Striped. I5 cts. per doz., 75 cts. per I00, $\$ 6$ per I,000.

All Colors Mixed. A mixture of all the above varieties. I5 cts. per doz., 60 cts. per I0o, $\$ 5$ per 1,000 .
p

\section{AUTUMN-FLOWERING GROGUS AND COLGHICUMS}

Very effective and handsome hardy plants, the flowers of which come through the ground without leaves in the fall, the leaves appearing the following spring. These bulbs can also be grown in the fall of the year in shallow bowls of water, or in pots of earth, when they will come into bloom in two weeks after planting, making a display at a time when blooming plants are scarce. Each Doz. Ioo Colchicum autumnale major. Beautiful deep rose; extra-large bulbs.......................... $\$$ Io $\$$ I $00 \$ \$ 70$

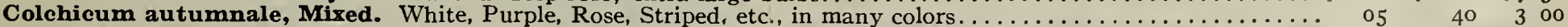
Crocus speciosus (Byzantine Wonder). Bright lavender-colored flowers, feathered with blue; bright orange anthers. . I5 I 50 Io oo 


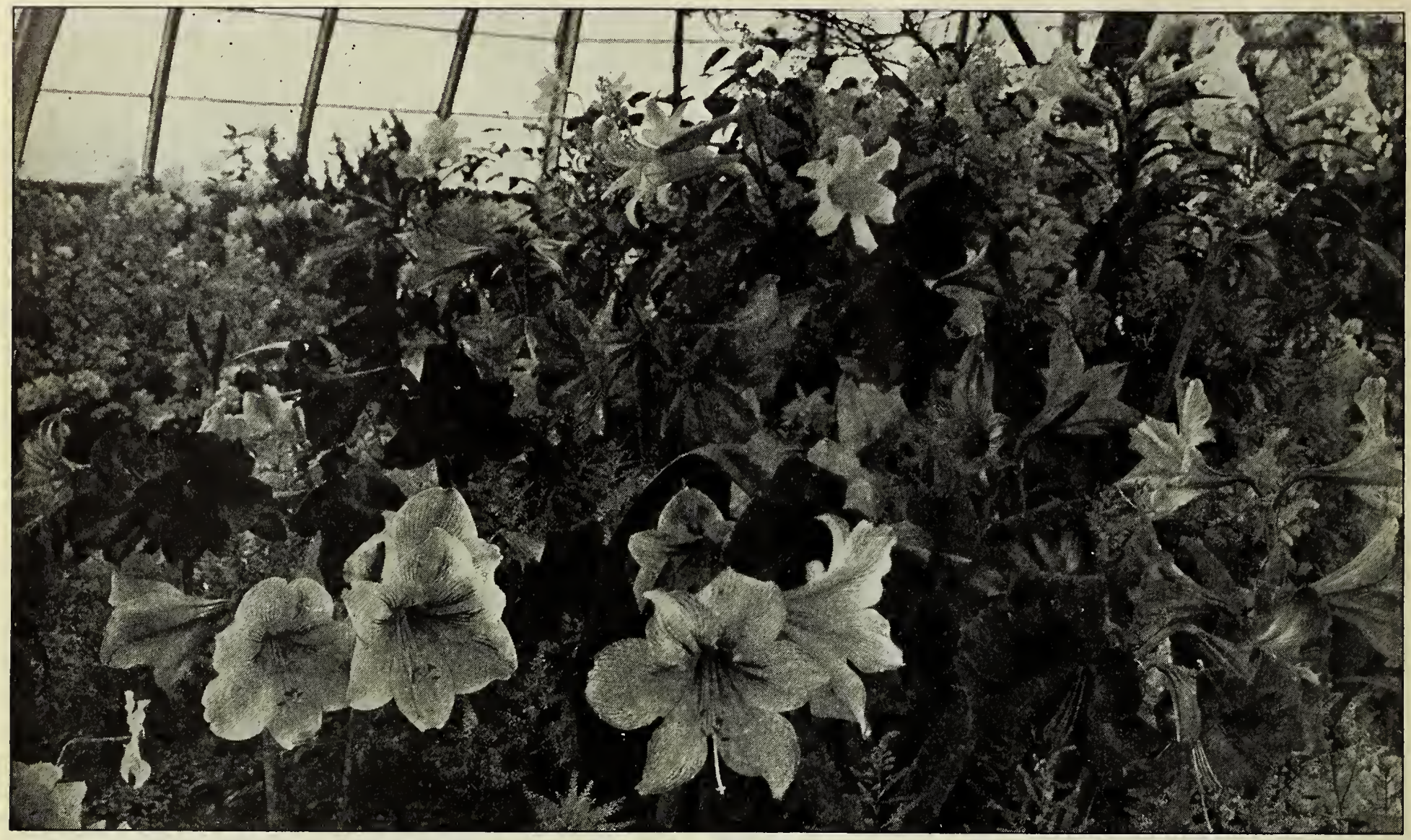

Amaryllis, Giant-flowering Vittata Hybrids

\section{GENERAL LIST OF BULBS}

\section{AMARYLLIS}

Giant-flowering Vittata Hybrids. Conceded to be and - most noble and magnificent section of the Amaryllidaceæ. The stock we have supplied for several seasons has been grown in Bermuda, the seed originally supplied by a most reliable hybridist of this plant. It would require a great amount of space to offer them with descriptions of the several representative types, so we confine ourselves to listing in two general classes-red ground, variegated with white; white ground, variegated with red. The red varies in tones from a brilliant fiery color to crimson; the variegation is sometimes a broad blaze of white in center of each petal; again, the ground color is white, abundantly streaked with red or crimson. The flower-spikes are from I to 3 feet high, the foliage long and graceful. Flowers, borne in clusters, of ten 8 inches across. Extra-strong bulbs, 75 cts. each, $\$ 8$ per doz., $\$ 60$ per roo.

Belladonna major. Large; violet and white........ \$o I5 $\$$ I I 50

Equestris (The Barbadoes Lily). Bright orangescarlet, with white throat.

Formosissima (Jacobæan Lily). Brilliant scarlet.....

Johnsonii. Crimson, striped with white.

Hallii (Lycoris squamigera). Bright rosy lilac flowers, fragrant, 3 to 4 inches across, in August. The foliage appears in spring, disappears in June, and is followed two months later by the naked flowers......

$\begin{array}{lll}25 & 2 & 50 \\ 15 & \text { I } & 50 \\ 25 & 3 & 00\end{array}$

\section{ACHIMENES}

Profuse summer-blooming plants for the conservatory or windowgarden. Flowers of many charming colors, ranging through various shades from white to crimson, also spotted. Io cts. each, $75 \mathrm{cts}$. per dos., \$5 per I00. Ready in November.

\footnotetext{
Cocoanut Fiber is an excellent substitute for soil; Amaryllis can
} be grown with good results in Fiber.

\section{AGAPANTHUS UMBELLATUS}

(African Lily)

Handsome summer-and autumn-flowering plants, throwing up large umbels of twenty to thirty blossoms. They should be grown in pots or tubs, in soil similar to that suggested for hyacinths. They are particularly suitable for piazza or terrace decorations, and may also be forced in the greenhouse. White, $25 \mathrm{cts}$. each, $\$ 2$ per doz.; blue, 25 c. each, $\$ 2$ per doz. If ordered by mail, add Ioc. each for postage.

\section{ALLIUMS}

Neapolitanum. An excellent variety for winter-flow- Doz. 100 ering, now extensively forced by florists for cut-

flowers, being of pure white, with green stamens, borne

in large, loose umbels. Height $I_{5}$ to $\mathrm{x} 8$ inches...... $\$ 0$ I 5 \$ $\$$ Moly. Yellow...................... I I $_{5} 00$ Ostrowskyanum. Rose.................. $25 \quad 200$

\section{ANEMONES}

Very showy flowering plants, valued for their hardy nature, and also because they will flower at any required season, according to the time the roots are kept out of the ground. May be grown in pots or forced in frames.

Poppy-flowered. These handsome single Anemones Doz.

Ioo

have large, beautiful, saucer-shaped, poppy-like

blossoms, flowering continuously throughout spring

and early summer.

Single Mixed ........................ 25 \$I 50

Double Mixed .................... 30 x 75 


\section{ANEMONES, continued}

Fulgens. The rich, dazzling scarlet flowers Each Do:. 100 and light, elegant growth render it the most attractive flower of spring. It is valuable for cutting, as it lasts a long time............\$o the above; very beautiful

St. Brigid. A new and greatly improved race of Irish introduction. The flowers are double semi-double and single, and range in color from maroon and deep scarlet to flesh-pink, and from lilac to purple................ \$o 05

05
$\$ 035 \$ 2 \quad 50$ 05 $50 \quad 300$

Double Mixed......................

\section{ANOMATHEGA GRUENTA}

(Scarlet Freesia)

A very pretty plant for pot culture. Grows about a foot high; flowers resemble the freesia in form, but are of a beautiful scarlet. I 5 cts. per doz., \$I per Ioo.

\section{ALSTR OEMERIA (Peruvian Lily)}

Tuberous-rooted plants, with large, lily-like flowers of great beauty, borne in clusters during the summer; they are splendid for cutting, being of much substance and lasting in perfection a long time. Splendid subjects for either pot culture or for planting out in frames. Very robust and abundant bloomers. Colors crimson, rose, yellow and purple, shaded scarlet and marked. 2 to $4 \mathrm{ft}$. Mixed Colors. io cts. each, $\$$ I per doz., $\$ 7.50$ per I00. Ready in November.

\section{BABIANA}

A charming genus bearing spikes of flowers, characterized by the striking contrast of distinct hues in the same flower. They vary in color from the richest carmine to the brightest blue, many of them being sweet-scented. They are not hardy north of Washington. Five or six bulbs in a 6-inch pot make lovely specimens. Height, 6 to 9 inches. Mixed Varieties. $25 \mathrm{cts}$. per doz., \$I.50 per Ioo.

\section{CAMASSIA ESCULENTA (Indian Quamash)}

Perfectly hardy, thriving in sheltered and partially shaded situations; the stout flower-stalks grow from 2 to 3 feet high, and bear 20 or more large blue flowers, each 2 inches across. A large clump in bloom is very effective. $20 \mathrm{cts}$. per doz., $\$ 1.25$ per I00, $\$ 10$ per I, 000.

\section{CHIONODOXA (Glory-of-the-Snow)}

Most charming spring-flowering bulbs. They produce flower-spikes bearing ten to fifteen scilla-like flowers. They are perfectly hardy, and will thrive in any good garden soil. Fine for pot culture for winter-blooming. $\quad$ Each Doz. 100 Luciliæ. Bright blue, with clear white center.\$O O2 $\begin{array}{llll}\text { \$o } & 20 & \text { \$I } 25 & \end{array}$ Sardensis. Very deep blue............... 03 25 I 25

\section{CROWN IMPERIALS}

Well-known hardy border plants, bearing clusters of immense, pendent, bell-shaped flowers, surmounted with a tuft of green leaves. They do better if planted in good, rich soil, and may be left undisturbed for years. If ordered by mail, add $5 \mathrm{cts}$. each for postage.

\begin{tabular}{|c|c|c|c|}
\hline$\ldots \ldots \ldots$ & $\begin{array}{l}\text { Each } \\
\text { So } 15\end{array}$ & $\begin{array}{l}\text { Doz. } \\
\text { DI } 50\end{array}$ & $\begin{array}{l}100 \\
12 \quad 50\end{array}$ \\
\hline & 20 & 200 & \\
\hline riegated $f$ & 25 & & \\
\hline Sul & 20 & 200 & I 5 \\
\hline 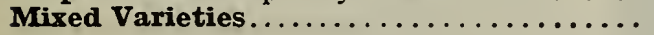 & Io & I 00 & \\
\hline
\end{tabular}

\section{GYCLAMEN PERSICUM GIGANTEUM}

We have a magnificent strain of this most desirable greenhouse bulb which has been grown especially for us, and which we know to be far superior to any stock heretofore offered. Large-size bulbs, 25 cts. each, $\$ 2$ per doz., $\$ 12$ per I00.

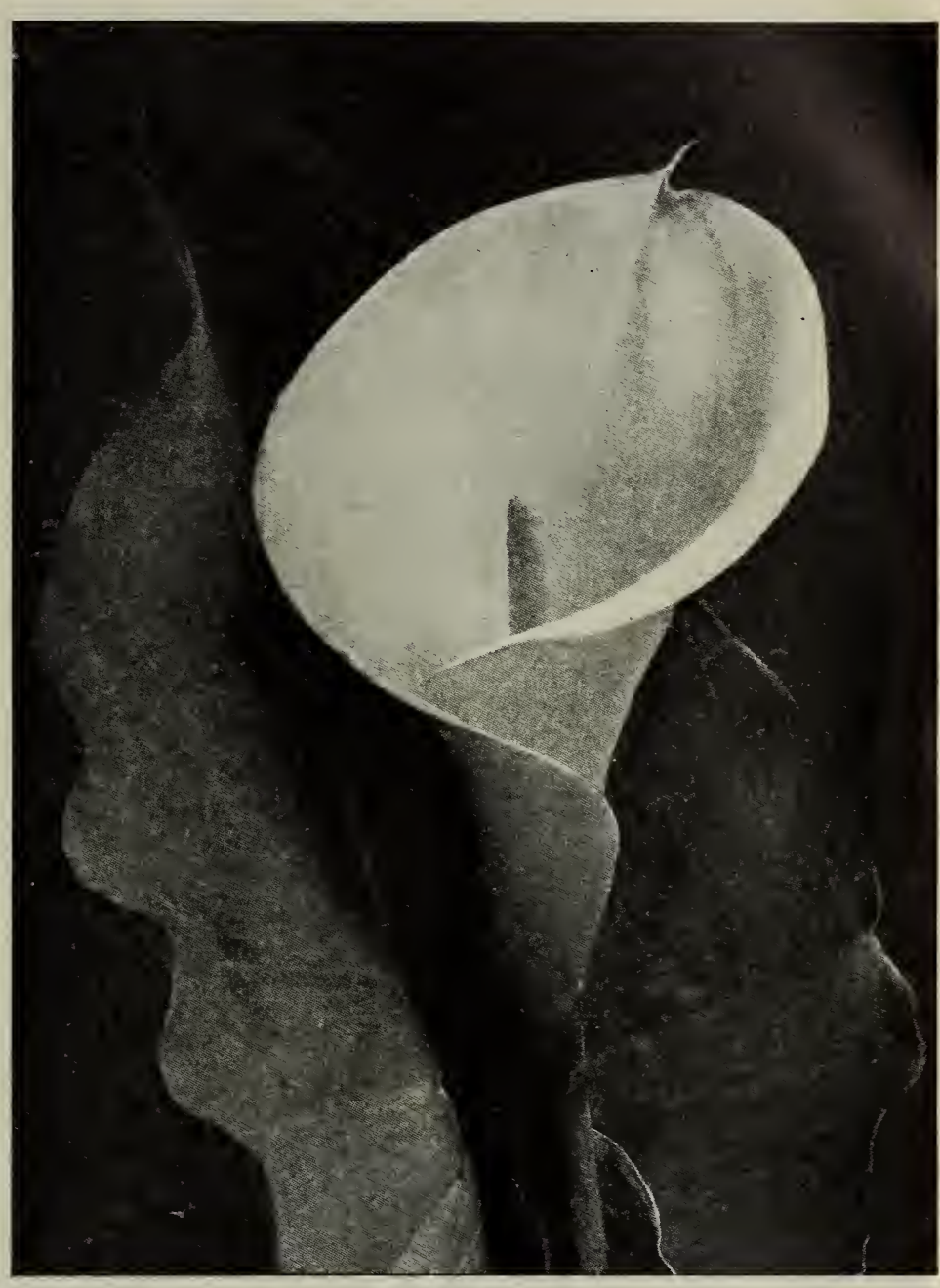

White Calla Lily

\section{CALLA LILIES}

These like a stiff, clayey soil with a small quantity of shredded cow manure; bulbs should be set with the crown, or top, protruding just above the surface. When in growing condition, warm water given several times during the week will hasten the flowering period and increase the number of blooms; of the large-flowering varieties plant but one in a pot; of the Little Gem plant from three to six in a pot. We call especial attention to the Yellow Calla, which is one of the grandest varieties in cultivation, and most valuable for house or conservatory decoration. See the description below. Plant Callas indoors only.

WHITE (Richardia AEthiopica).

Monster Size..........

Mammoth Size...........

\begin{tabular}{|c|c|c|c|}
\hline $\begin{array}{l}\text { Each } \\
\$ 0 \quad 40\end{array}$ & $\begin{array}{l}\text { By mail } \\
\text { \$o } 45\end{array}$ & $\begin{array}{l}\text { Doz. } \\
\$ 4 \text { oo }\end{array}$ & $\begin{array}{l}100 \\
\$ 30 \quad 00\end{array}$ \\
\hline 2 & 30 & 2. 50 & I 7 \\
\hline I5 & I 8 & 50 & IO \\
\hline IO & 12 & I 00 & \\
\hline
\end{tabular}

First Size..................

BLACK. Dark flower. Should be watered sparingly until growth appears. Ready in October. I5 cts. each, \$I.5O per doz., \$IO per IOO.

SPOTTED. White flower; green foliage, spotted white. Ready in October. Io cts. each, \$I per doz., \$7 per Ioo.

LITTLE GEM. Our stock of these is genuine, being procured directly from the original source. The plant and flower are indeed a curiosity. In appearance and growth it is just like the White Calla, except that the flower and plant are much smaller. They are very free bloomers and are excellent for cutting or as pot plants. Io cts. each, \$I per doz., \$6 per Ioo.

YELLOW (Richardia Elliottiana). A grand novelty, one that should be planted extensively. The deep golden yellow flowers are truly magnificent, and produced in abundance. The green foliage is spotted creamy white, which adds to its beauty. $40 \mathrm{cts}$. each, $\$ 4.50$ per doz., $\$ 30$ per IOO. 


\section{DIELYTRA SPECTABILIS}

(Bleeding Heart)

Ready in November

A very ornamental spring-flowering plant. The flowers, which are heart-shaped, produced on long, drooping stems, are of a beautiful rose-and-white color combination. It is the earliest spring plant to flower, with the exception of some bulbs. After the flower has bloomed the plant makes a very attractive appearance with its foliage. In order to make strong root-development, the top may be cut away to the ground after the foliage has thoroughly developed. Dielytra forces very readily and is very attractive in a greenhouse or conservatory. We offer very strong, large roots $25 \mathrm{cts}$, each, $\$ 2.50$ per doz., \$I5 per Ioo.

\section{ERANTHIS HYEMALIS (Winter Aconite)}

Early in spring the golden blossoms look charming, resting on an emerald-green cushion of leaves, and forming a striking contrast to the snowdrops, scillas and chionodoxas. The foliage remains long after the flowers, making the plant especially valuable in moist situations, such as under trees, which the Winter Aconite enjoys, and where few other flowering plants will thrive. 3 to 8 inches high. 25 cts. per doz., $\$$ I.50 per I00, $\$$ IO per I,000.

\section{ERYTHRONIUM (Dog's-Tooth Violet)}

Beautiful, hardy plants, especially suited to moist, shady situations; the leaves are handsomely variegated; flower-stems about a foot high, bear lily-like blossoms of different colors; does well in pots.

Americanum. Large, cream-colored flowers, with maroon base; leaves richly mottled. $50 \mathrm{cts}$. per doz., $\$ 2.50$ per Ioo. Dens-Canis album. White. $25 \mathrm{cts}$. per doz., $\$ 2$ per Ioo. Dens-Canis, Rose Queen. 25 cts. per doz., $\$ 2$ per Ioo. Dens-Canis, Purple Flag. $35 \mathrm{cts}$. per doz., $\$ 2.50$ per roo. Dens-Canis, Mixed. I5 cts. per doz., \$I per 100.

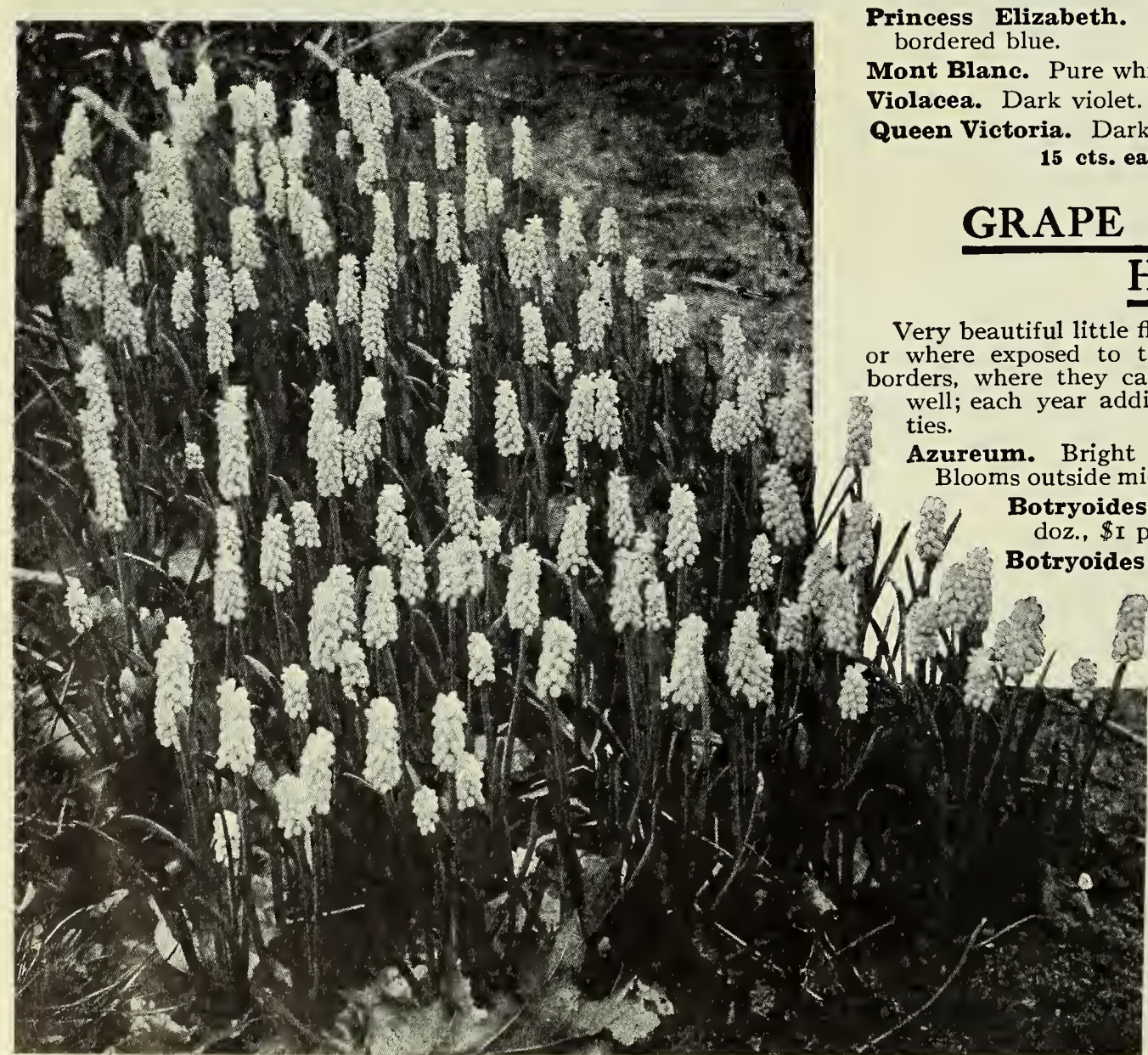

Grape Hyacinths Heavenly Blue

\section{EREMURUS ROBUSTUS}

A noble and rare bulbous plant from Turkestan, and one of the choicest subjects for the permanent hardy border. It thrives best in a well-drained, sheltered, sunny position, and prefers a deep, sandy loam to which has been added a liberal quantity of well-rotted cow manure. A covering of 4 or 5 inches of leaves or litter will be beneficial and save the young shoots, which start early, and are liable to be damaged by late frosts. It produces immense flower-stems, 6 to Io feet high, bearing a dense raceme of flesh-pink flowers, each nearly 2 inches across. Extra-strong, flowering roots. $75 \mathrm{cts}$. each, $\$ 6$ per doz. Ready in October.

Himalaicus. Another noble variety from the temperate Himalayan Mountains, 4 to 8 feet high. Raceme nearly 2 feet long, of lovely pure white flowers as large as a fifty-cent piece. This is perhaps the hardiest and easiest grown of this magnificent genus. Strong, flowering roots, $75 \mathrm{cts}$. each, $\$ 6$ per doz. Ready in October.

\section{FRITILLARIA MELEAGRIS}

Singular, dwarf, spring-flowering plants, bearing large, pendent bellshaped flowers of various colors, in yellow, white, black, purple, striped and splashed and checkered in the most curious way. They. are invaluable for pot culture, and exceedingly pretty when grown in large groups in the garden border or wild garden in a dry situation. Meleagris alba. Pure white. 5 cts. each, $30 \mathrm{cts}$. per doz., $\$ 2$ per 100. Mixed Varieties. 3 cts. each, 25 cts. per doz., $\$$ I. 50 per Ioo.

\section{GLOXINIAS}

S. \& W. Co.'s Superb Strain

\section{Ready in December}

Emperor Frederick. Red, bordered white.

Emperor William. Violet, bordered white.

Mont Blanc. Pure white.

Violacea. Dark violet. 15 cts. each, $\$ 1.50$ per doz., $\$ 10$ per 100
Madame Helene. White, crowned violet.

Defiance. Scarlet.

Princess Mathilda. White, bordered rose.

King of the Reds. Deep scarlet. Prince Albert. Dark violet. Finest Mixed.

\section{GRAPE AND FEATHERED HYACINTHS}

flowers for planting in masses, either in shade the sun. When planted out in herbaceous where can be left undisturbed, they do exceedingly well; each year adding to their already profuse-blooming quali-

Breum. Bright blue. One of the earliest spring flowers. Botryoides alba (White Grape Hyacinth). I5 cts. per doz. \$I per Ioo, $\$ 8$ per $\mathrm{I}, 000$.

Botryoides crerulea (Blue Grape Hyacinth). I 5 cts. per doz., \$I per 100, \$8 per I,000.

Heavenly Blue. This variety is the the Grape Hyacinths. The bells are large and form a fine truss. Splendid effects are produced by massing in the garden or border. $35 \mathrm{cts}$. per doz., $\$ 2.50$ per Ioo.

Plumosum. (Feathered Hyacinth). Violet-blue. An excellent subject for the wild garden. 25 cts. per doz., $\$ 1.25$ per Ioo.

The variety Heavenly Blue when used as a border around Narcissi makes a splendid contrast. Excellent for growing in fiber in shallow dishes in the home. 


\section{WINTER - FLOWERING GLADIOLI}

\section{Cardinalis, Nanus or Colvillei Type \\ Ready in November}

This Gladiolus belongs to the most useful class of all. They can be forced by the end of March, and come in very useful when most of the other bulbs have gone. Noted for their lasting qualities; every flower opens to the extremity of the spike. Their rich coloring and vivid markings on the lip petals rival those of the orchids, and we recommend them either for border planting or for forcing in pots or flats.

Ackermanni. Salmon-orange, with white blotches, edged scarlet. 20c. per doz., \$I.25 per Ioo, \$10 per I, 000.

Blushing Bride (Delicatissima). Rosy white, with carmine blotch; large flowers. I5 cts. per doz., \$I per I00, $\$ 8$ per I,000.

Delicatissima superba. A very beautiful and white, large bright carmine blotch us Gladiolus. Pure $\$ 3.50$ per 100, \$30 per I, 000.

Gordon. Very delicate lilac; large and well-formed flower. 50 cts. per doz., $\$ 3.50$ per Ioo, $\$ 30$ per I,000.

Fairy Queen. Light carmine-red, white blotch, arre carmine bordered. 20 cts. per doz., $\$ 1.25$ per 100, \$10 per I,000.

Peach Blossom. Most delicate pink. The name each Blossom. indicates the color well, as it is exactly like that peach of blossoms. 25 cts.'per doz., \$1.75 per IOO, \$I 5 per I,000.

Queen of Holland. Pure white with a distinct flowering variety, producing large flowers of an extremely pleasing color. One of the most beautiful of its class. 35 cts. per doz., $\$ 2.50$ per IOo, $\$ 20$ per I,000.

Tristis (Grandis). A slender-growing, grassy species, scented, yellow flowers, the petals of which do not reflex so fully as most others. Quite pretty and novel. 75 cts. per doz., $\$ 5$ per I00, $\$ 45$ per I, 000 .

CoLvHLEI, The Bride. A small-flowered type used very extensively for forcing in greenhouses among carnations, etc. Compact spikes of pure white flowers. 25 cts. per doz., \$I per IOO, \$8 per I,OOO.

\section{Large-Flowering Gladioli}

\section{Ready in December}

The following five varieties, which are of proven value for outdoor planting, are equally good for forcing. A carnation temperature suits them best.

America. Best of the light pinks. 75 cts. per doz., $\$ 5$ per roo. Augusta. Best of the whites for forcing. 60 cts. per doz., $\$ 4$ per 100 Brenchleyensis. Dazzling vermilion-scarlet. Few varieties are equal in brilliance. $50 \mathrm{cts}$. per doz., $\$ 3$ per 100.

May. White, flaked crimson; splendid forcer. 50 cts. per doz., \$3 per roo.

Mrs. Francis King. Flowers gigantic size; soft scarlet; on stems 4 feet long -often longer when grown outdoors. $75 \mathrm{cts}$. per doz. $\$ 5$ per 100.

\section{IXIAS}

The Ixia is a beautiful little winter-flowering bulb, with long slender, graceful spikes of bloom. The colors are rich, varied and beautiful, the center always differing in color from the other parts of the flower, so that the blossoms, expanding in the sun's rays, present a picture of gorgeous beauty. Very desirable for pots.

Alba mutabilis. Rose, changing to white.

Craterioides major. Beautiful, brilliant scarlet.

Emperor of China. Rich yellow and brown.

King of the Yellows. Yellow, dark purple eye.

Morning Star. Bright rose.

Viridiflora. Soft green with velvety black center; very beautiful. 75 ots. per doz., $\$ 5$ per 100

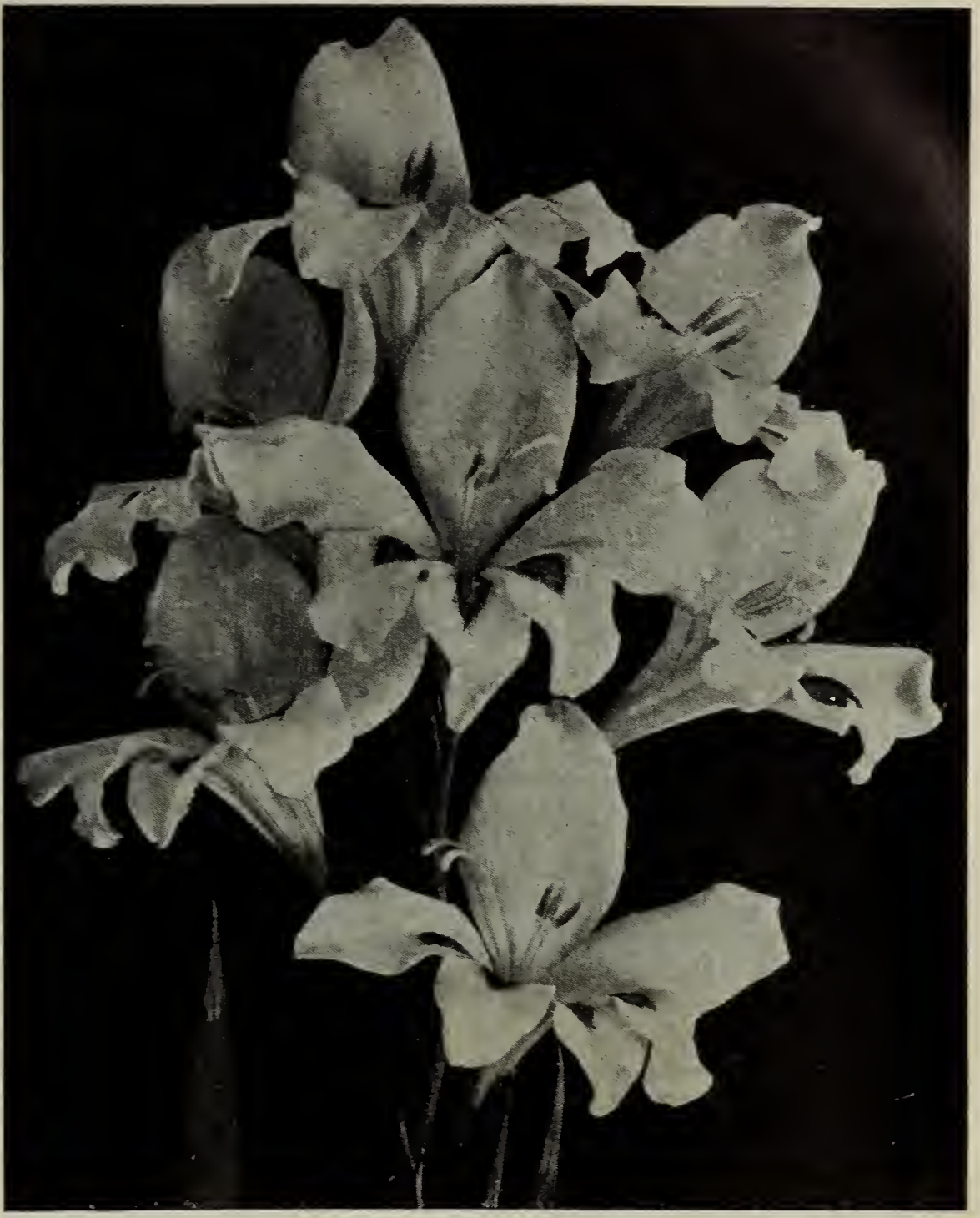

Gladiolus, Peach Blossom

\section{NERINES (Amaryllidaceæ)}

There is an ever-increasing demand for these exquisitely beautiful flowering bulbs. Established in pots in an ordinary greenhouse, with a temperature ranging from 35 degrees to 60 degrees, they produce annually their large, handsome umbels of blooms on scapes varying from 12 to 24 inches long. The best time for repotting is during August, using a good sandy loam with a little leaf-mold and well-decayed cow manure. Flowering as they do in October and November, we find them a very excellent subject.

Coruscans. Brilliant orange-scarlet. $75 \mathrm{cts}$. each, $\$ 7.50$ per doz., $\$ 50$ per 100 .

Fothergilli major. Vivid scarlet; nothing in the way of color can surpass the splendor of this flower, and its texture seems too delicate even for that of a flower; by artificial light the crystalline cells of the petals sparkle like jewels. It is also the most floriferous of the group. 75 cts. each, $\$ 6.50$ per doz., $\$ 50$ per Ioo.

Flexuosa excellens. Bright rosy pink; a very beautiful variety. $50 \mathrm{cts}$. each, \$5 per doz., \$40 per Ioo.

Sarniensis (True Guernsey Lily). Color deep rose. 25 cts. each, $\$ 2.50$ per doz., \$20 per IOO.

Nerines Grown in Fiber.

We have had excellent sucbulbous cess in growing this beautiful ing same. Sufficient fiber to plant half dozen bulbs $25 \mathrm{cts}$., one dozen bulbs $50 \mathrm{cts}$. 


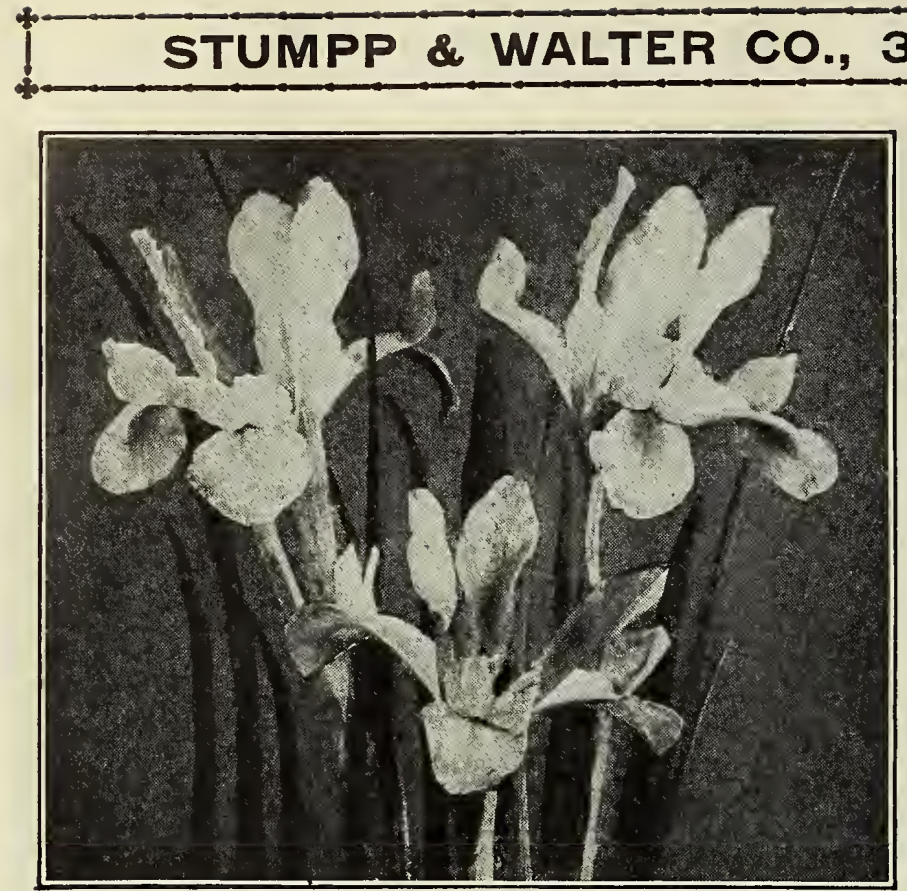

Spanish Iris

\section{SPANISH IRIS}

(Iris Hispanica)

A very beautiful flower, and an old inhabitant of English gardens. This Iris is absolutely hardy in the severe New England climate, and does particularly well in light, friable soil between shrubs and perennials. The flowers are produced in early June, and the display of the bright colors make a most gorgeous effect. The proper thing to do is to mass about fifty bulbs of a single variety in a clump and allow it to remain in the ground undisturbed until the grassy stalks show the impoverished soil and degenerated roots. We have carefully selected the varieties offered herein and know they will give perfect satisfaction.

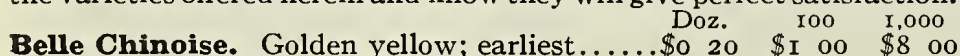

British Queen. Pure white; one of the best.. $20 \quad$ I $00 \quad 600$

Cajanus. Bright yellow; large flowers on long

stems.......................... 20 I $00 \quad 600$

Darling. Bright blue............... 20 I $00 \quad 700$

Golden Cup (Thunderbolt). Largest bronze; very vigorous grower............... $40 \quad 200$ I5

Excelsior. Largest light blue............ $20 \quad$ I $00 \quad 600$

King of the Blues. One of the best dark blues. $25 \quad$ I $00 \quad 8$ o0

L'Innocence. One of the best new pure whites. I $5 \quad 75 \quad 500$

Special Mixture.................. I5 $75 \quad 500$

\section{ENGLISH IRIS}

\section{(Iris Anglica)}

This type is very similar in character to the Spanish varieties, somewhat dwarfer, more robust, with heavier foliage and larger flowers, flowering two weeks later. These are not suited to forcing, blooming in June.

Belle Agathe. Mauve.

De Lesseps. Large; blue.

Dora. Creamy white, spotted blue.

La Grandesse. White, tinged light blue.

Lucinda. Light porcelain, spotted blue.

Mont Blanc. Pure white.

35 cts. per doz., $\$ 2$ per $100, \$ 15$ per $1,0 c 0$

\section{MOURNING IRIS}

\section{(Iris Susiana)}

The groundwork of the flower is silvery gray, so mottled and veined and lined with dark chocolate and black as to leave one under the impression that it is only a silver lining showing through. Io cts. each, \$I per doz., \$7 per Ioo.

\section{GERMAN IRIS}

(Iris Germanica)

The German Iris is one of the most desirable, early spring-flowering plants. The flowers are of large size and exquisite colors. It delights in low, wet ground, and does equally well in the border. No garden is complete without a collection of these beautiful flowers. Agnes. White, edged lilac.

Asiatica. Violet-purple.

Aurea. Golden yellow.

Darius. Large yellow and lilac.

Empress. Victoria-blue, falls purple.

Gloire de Fillegom. Porcelain-blue.

Innocenza. Pure white.

Macrantha. Blue and violet.

Mad. Chereau. White, frilled blue.

Maori King. Golden yellow.

Mrs. Horace Darwin. White, veined violet.

Queen of May. Rosy lilac.

Named varieties 15 cts. each, $\$ 1.50$ per doz., $\$ 8$ per 100 ; mixed varieties 10 cts. each, $\$ 1$ per doz., $\$ 5$ per 100

\section{MISCELLANEOUS 1RISES}

Alata (Scorpion Iris). About I foot high, with broad Doz. 100 leaves. The flowers are very large (4 to 6 inches across), of lilac-blue, with blotches of bright yellow spotted with a darker shade...............\$o $75 \quad \$ 500$

Florentina. Very beautiful pure white, slightly shaded with blue and with a yellow beard; deliciously violetscented.......................... $75 \quad 500$

Histrioides. Large, bright blue flowers, dark spots... I 25 Io 00 Pavonia (Peacock Iris). Pure white with a bright blue spot on each petal. Fine for pot or garden culture.

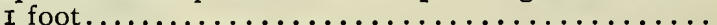

\section{IRIS PALLIDA DALMATICA}

This is the grandest variety of all the German Irises. Color deep, clear lavender; very large flowers, sweet-scented. This Iris should be planted largely where cut-flowers are in demand, as it is certainly the best of its class. A grand variety for massing in borders; it is superb. 25 cts. each, $\$ 2.50$ per doz., $\$ 20$ per Ioo.

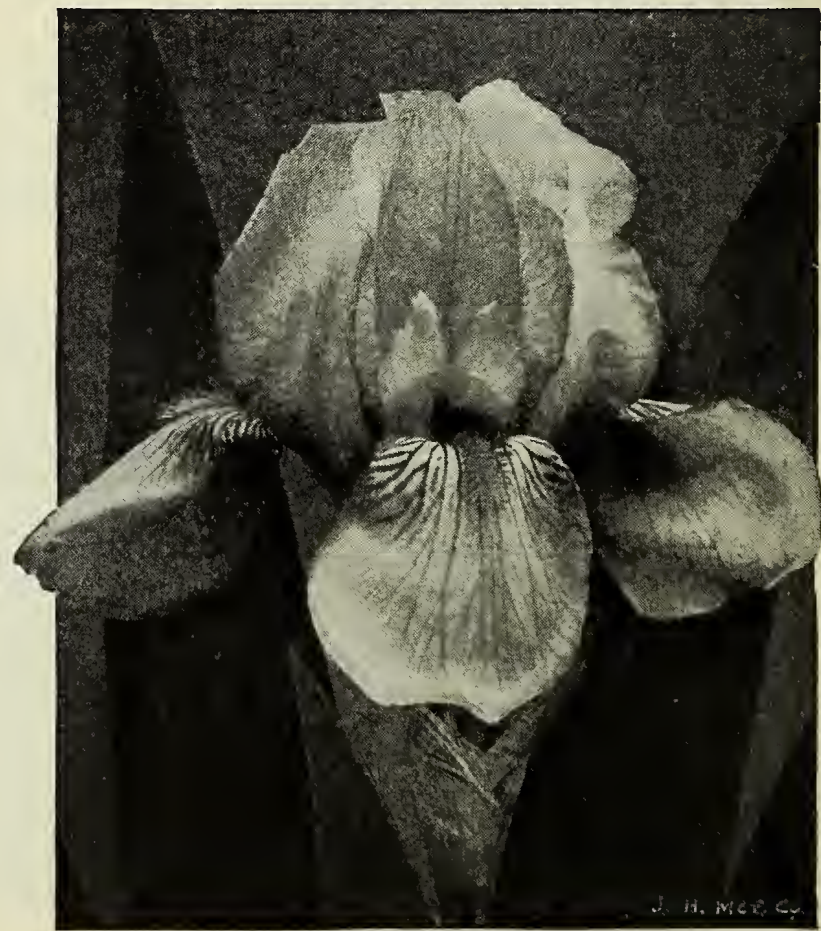

German Iris 

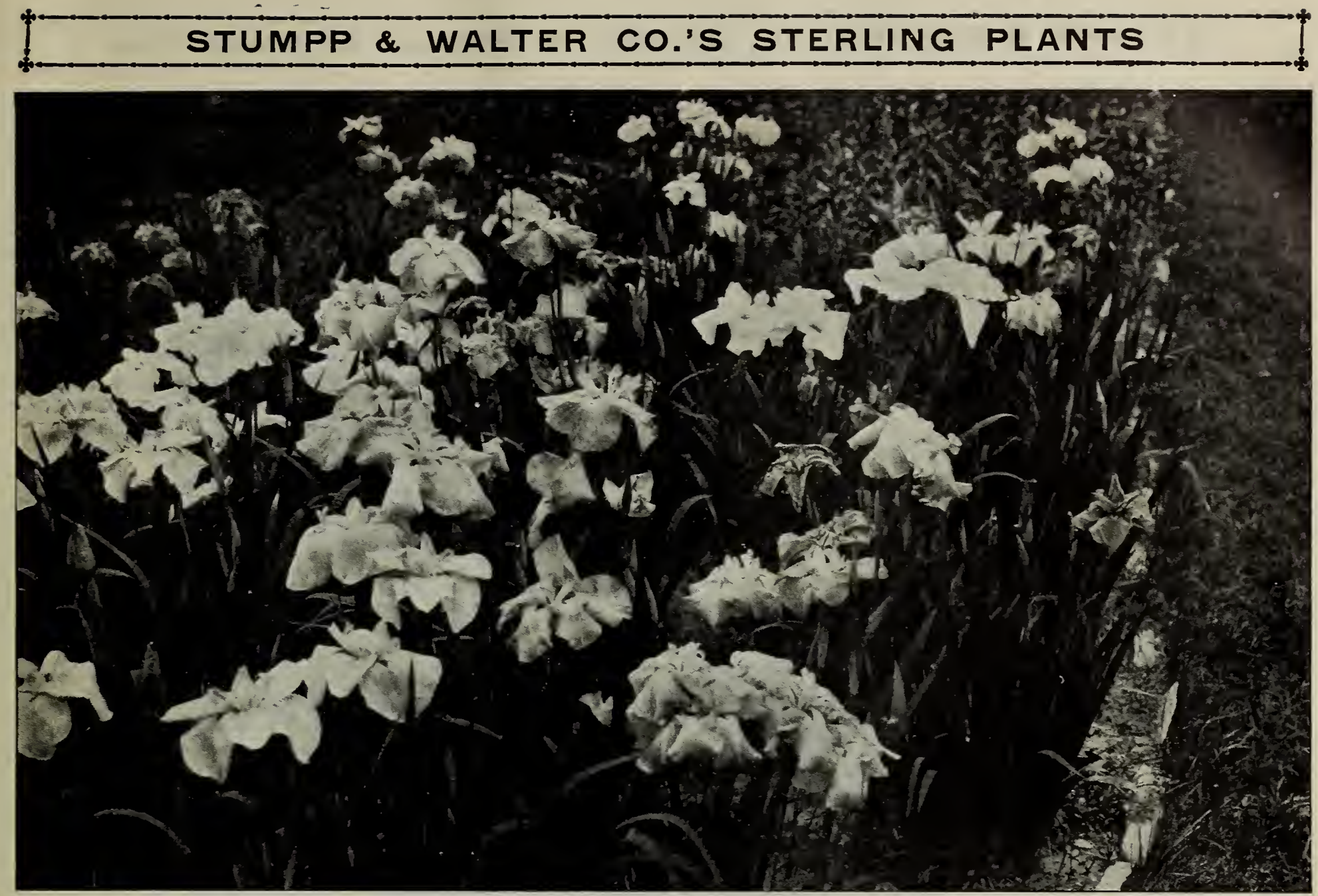

\section{NEW JAPANESE IRIS}

\section{(Iris Kaempferi grandiflora)}

The magnificence of these new Irises surpasses description. The flowers are of enormous size, averaging from 6 to 8 inches across, and of indescribable and charming hues and colors, varying like watered silk in the sunlight, the prevailing colors being white, crimson, rose, lilac, lavender, violet and blue, each flower usually representing several shades, while a golden yellow blotch surrounded by a halo of blue or violet at the base of the petals intensifies the wealth of coloring. The Japan Iris is perfectly hardy, and flowers in greatest profusion in June and July, and attains greatest perfection if grown in moist soil, or if plentifully supplied with water while growing and flowering. The following varieties have been selected from a large collection, grown by a famous Japanese horticulturist, and recognized as the finest assortment of Japanese Iris known. The different varieties having Japanese names, we have deemed it advisable to distinguish the various sorts by numbers, as follows:

1. White, yellow center, veined.

2. Dark purple edge, running to a blue-and-yellow center, under part of flower lavender.

3. Very light blue, white-veined, yellow center, inner petals of flower tinged with dark blue.

6. Maroon, yellow center, inner petals white with a purple top.

7. Dark blue, shading into light blue and white, rather streaked, inner petals purple-tipped, yellow center.

8. White, dark purple veins, yellow center, inner petals dark purple, shading to white.

9. Dark red, black and white veins, yellow center, white and purple inner petals.

11. White, well spotted dark pink, shading into pink at edges, yellow center, with a little purple border.

12. Dark purple, bright yellow center, dark blue inner petals.

19. Yellow center, blue-black veins, inner petals red, with red veins and blue spotted with white.

23. Yellow center, dark purple, varying to a lighter shade toward the edges, well-veined inner petals.

26. Yellow center, shading into light purple, then a light red, then a darker red, well spotted with a very dark red.

32. Very dark blue, yellow center, purple inner petals.

33. Yellow center, white and blue stripes, shading into a light violet, darker toward the edges, with a much heavier shade of violet directly on the edge, inner petals white tipped dark violet.
34. Yellow center, with rather a dark purple, shading into a light red, and a dark red near the edges, well-veined inner petals white, with purple edges.

35. Yellow center, white flowers with a dark purple edge or border.

36. Yellow center, very dark red flower, heavily veined, inner petals white and dark purple.

37. Yellow center, blue flower shading into a dark purple near the edge and border, white veining, inner petals very dark purple.

40. Yellow center, light and dark blue, spotted with very dark blue, inner petals white and dark purple.

41. Yellow center, dark purple, shading into light purple and darker purple again at the edges, well-veined inner petals of a light purple.

42. Orange center, rather a gray-white, shading into pure white at the edges, white veins.

43 Yellow center, very dark red, shading into a lighter red with rather a white-and-pink tipping; white spots appear occasionally on this flower; inner petals of light and dark purple.

46. Yellow center, entire flower is of dark purple, except the middle of each petal, which is a light blue, shading to a dark purple.

50. Orange center, red, with a little darker shade on the edge, wellveined, center petals white, purple border and a light red.

Prices of any of the above named varieties: 25 cts. each, $\$ 2.50$ per doz., $\$ 15$ per 100; or a complete collection, one each of the above 24 varieties. \$4.50. Large undivided roots 


\section{LEUCOJUM VERNUM}

(Spring Snowflake)

Pretty bulbous plants allied to the Snowdrop, but of much stronger and bolder habit, growing in rich soil from I to 2 feet high, and producing freely beautiful large white flowers, distinctly tipped with green; excellent for cutting. When once planted they take care of themselves, and should have a place in all hardy collections; can also be grown in pots. $25 \mathrm{cts}$. per doz., $\$$ I.5O per I00, \$I 2 per I,000.

\section{ORNITHOGALUM}

Arabicum (Star of Bethlehem). Very desirable for pot culture in the window-garden. The flowers are large, pure white, with a black center; borne on a tall spike. ro cts. each, $40 \mathrm{cts}$. per doz., $\$ 2.50$ per Ioo.

Umbellatum (American Star of Bethlehem). Used for naturalizing. $\$$ I per I00, $\$ 8$ per I,000.

\section{RANUNCULUS}

Very charming, dwarf-flowering plant having flowers of various bright, attractive colors. Plant late in autumn, about 3 inches deep, and protect by straw or leaves.

French Mixed. 5 cts. each, 20 cts. per doz., \$I per Ioo.

Persian Mixed. $5 \mathrm{cts}$. each, $20 \mathrm{cts}$. per doz., \$I per Ioo.

Turban Mixed. Hardiest sort. 5c. each, 20c. per doz., $\$$ I per Ioo.

\section{SPARAXIS}

They were formerly included in the genus Ixia, and bear a close resemblance to them, the main points of difference being that the Sparaxis are of more compact habit of growth, the flowers more bold, and somewhat larger and the flower spikes are not more than half as high, rarely growing more than 6 inches. Especially desirable for the window garden.

Splendid Mixed Varieties. 20c. per doz., \$I.25 per I0o. If ordered by mail, add 5 cts. per doz. for postage.

\section{SNOWDROPS}

These elegant little flowers, the first to open in spring, should be found in every garden, not only because they are the earliest spring flowers, but because they are the loveliest. The Snowdrop thrives in almost any situation or soil, and should be planted as early in the autumn as possible, as they suffer much if left long out of the ground.

Single Snowdrops.

Doz. I00

Double.

Elwesii, Giant Snowdrops

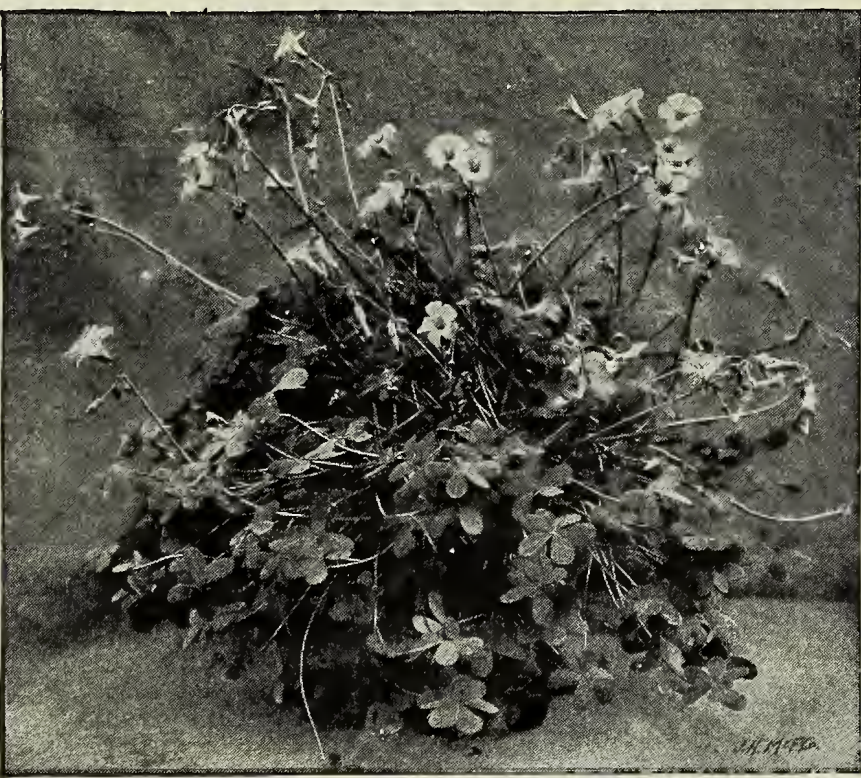

Bermuda Buttercup

\section{The Bermuda "Buttercup" Oxalis}

An unrivaled winter-flowering pot plant of the easiest culture, succeeding with everybody

This is one of the finest flowering plants for pot culture that we have ever seen; it is such a strong, luxuriant grower that one bulb will be sufficient for a 6- or 8-inch pot. Place in a dark, cool position for several days to root thoroughly, and remove to a sunny situation in the window or conservatory in a temperature of about 60 degrees Fahr., and the great profusion of bloom produced in uninterrupted abundance for weeks will astonish and delight you. The flowers are of the purest bright buttercup-yellow. Well-grown plants have produced as high as seventy flower stems at one time, and over I, 000 flowers in one season. Properly treated, the plant will flower in six weeks from the time the bulbs are planted. $3 \mathrm{cts}$. each, $30 \mathrm{cts}$. per doz., $\$ 2$ per 100

\section{OXALIS}

Very desirable and charming plants, particularly adapted for pot culture in the greenhouse or windiow garden. Plant the bulbs in September or October and keep in a moderate temperature. They are of the easiest culture and will bloom profusely during the winter months.

Bowiei. Rosy crimson; fine flower............\$0z.

Grand Duchess. White. 20 cts. per doz., \$1.25 per 100 .

Grand Duchess. Pink 20 cts. per doz., \$I.25 per roo.

Grand Duchess. Lavender. 20c. per doz., \$1.25 per I00.

Lutea. Single yellow. ro cts. per doz., 75 cts. per 100.

Lutea. Double. $30 \mathrm{cts}$. per doz., $\$ 2$ per Ioo.

Rosea. Rose. I5 cts. per doz., 80 cts. per IOO.

Versicolor. Crimson and white. 20 cts. per doz., \$I per Ioo.

Mixed, All Colors. 20 cts. doz., \$I per IOo.

\section{SCILLAS}

Most charming and desirable spring-flowering bulbs. The flowers resemble the Hyacinth, but are much smaller; their colors are more intense, and they come into flower much earlier. As an edging, or for filling small beds, if planted sufficiently thick, the effect is matchless. Treat in the same manner as hyacinths. Doz. Ioo

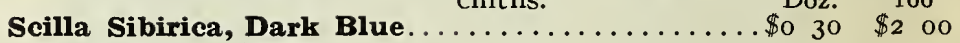

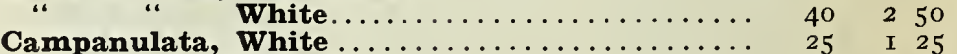

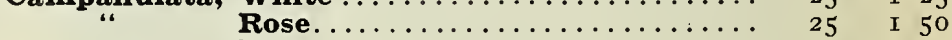

Blue ....................... 20 I 25

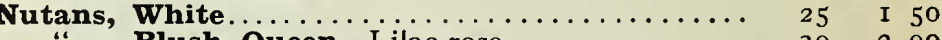
Blush Queen. Lilac-rose............. $30 \quad 2$. 300 Blue (English Bluebell) ............. 20 I 00

\section{TRITONIA}

Exceedingly bright and free-blooming bulbous plants, highly valuable for both garden and pot culture. The bulbs should be grown in pots in a coldframe during winter, and they can either be brought into the conservatory toward spring for blooming, or the bulbs can be kept dormant and planted out in May, like gladioli, and then lifted in the autumn for winter blooming.

Mixed Colors. Io cts. for 3, 30 per doz., $\$ 2$ per Ioo.

\section{TUBEROSES}

This is one of the most beautiful American plants, pertectly hardy, growing and flowering profusely in partially shady nooks about the lawn, under trees, etc. The flowers are large, of the finest white, changing in a few days to soft rose; if grown several in a pot it makes one of the best white winter flowers. Io cts. each, 75 cts. per doz. $\$ 5$ per Ioo

\section{TRILLIUM GRANDIFLORUM}

\section{(Great American Wood Lily)}

Large, pure yellow, crocus-like flowers, which are produced with the leaves during late autumn. This is supposed by some writer to be the true Lily of Scriptures, as it grows abundantly in the vales
Arrive in November. When planted in pots, during November to January, these bulbs will flower during the winter. FIRST SizE, 5 cts. each, 35 cts. per doz., $\$ 2$ per IO0; MAMMOTH BuLBS, Io cts. each, 60 cts. per doz., $\$ 4$ per Ioo. 

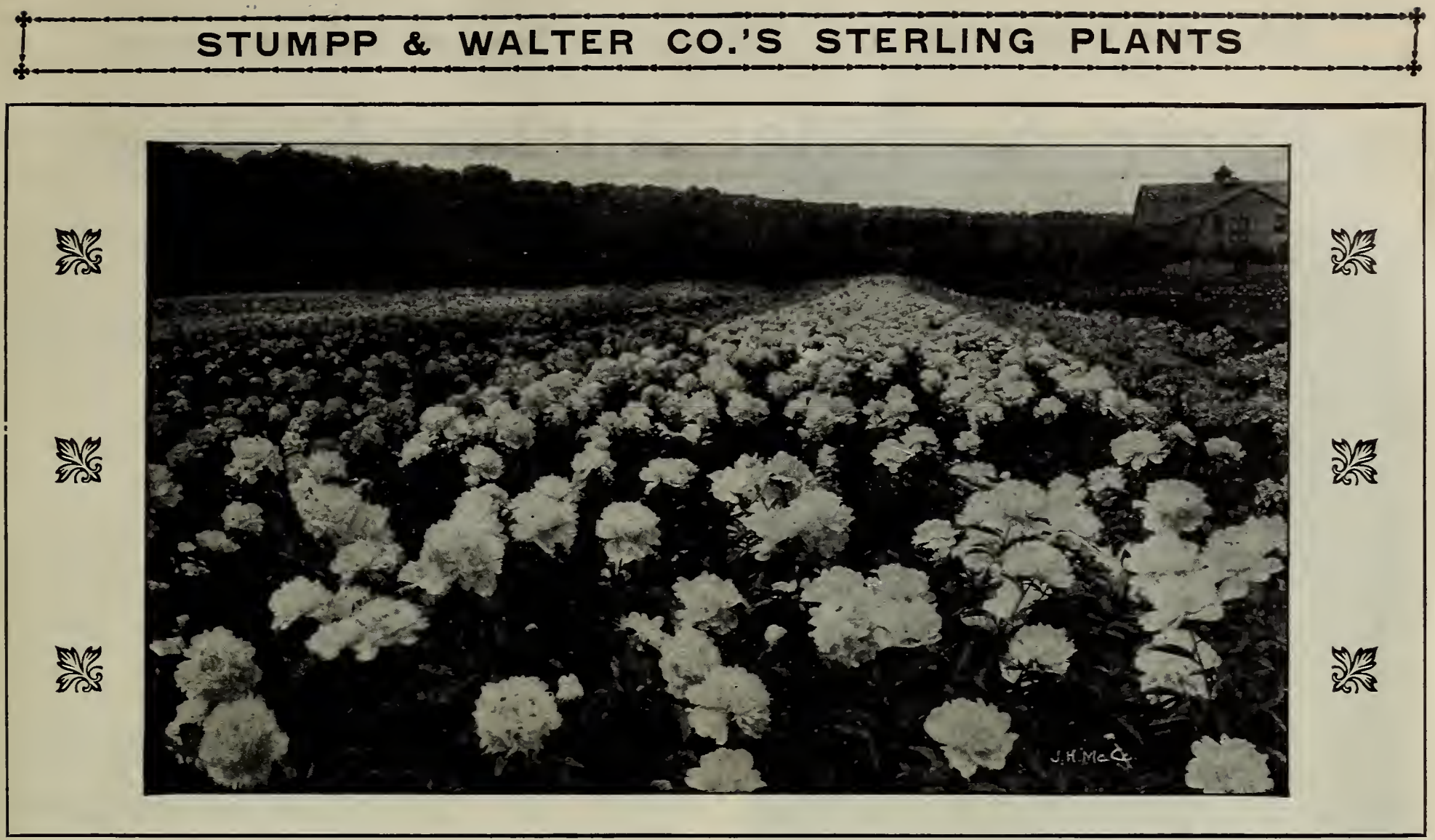

\section{HERBACEOUS PEONIES}

\section{TWENTY MODERN VARIETIES}

Peonies rank among the most beautiful of all hardy perennials, and no garden is complete without their charming influence. The popular interest in many parts of the world has brought a very gratifying improvement in the Peony. In the newer sorts gigantic flowers have been produced, reaching, in many instances, the large size of 7 to 9 inches in diameter and 5 to 6 inches in depth, with strong, stiff stems $21 / 2$ to 3 feet long. The permanency of the Peony should especially recommend them to your favor; for, once planted in suitable soil, they will continue to grow better and larger each year.

Strong, well-developed roots, 4 to 5 eyes. If planted from September to November, will flower following year

Alba plena. Immense, pure white flowers; of robust Each Doz. habit and a very free bloomer.................\$o 35 \$3 50

Berlioz (Crousse). Brilliant dark red, tinted rose; flowers very large size, imbricated. A fine dwarf grower; excellent keeper.

Candidissima (Calot). Large, cream-white guard petals; center sulphur-yellow, with green heart, very full and compact; habit slightly drooping. The earliest of the white and yellow varieties.

Couronne d'Or. (Calot.) Large, flat, semi-rose type; pure white, with a ring of yellow stamens around a tuft of center petals, tipped carmine. Medium tall, vigorous grower and free bloomer. Late.

Duchesse de Nemours. (Calot.) Guard petals white, center lemon-yellow with greenish reflex. Large, cupshaped, full bloom. Among all Peonies there is nothing so exquisitely chaste as this variety in a half-open state. Delicately fragrant.

Duc de Wellington. (Calot.) Very large, well-formed, sulphur-white bloom; habit ideal; stems very firm and long. Strong grower; very fragrant. Scarce.

Edulis superba. (Lemon.) Large, loose bloom of dark pink of even color, flat when fully open; fragrant; upright, strong-growing plant. Early.

Festiva maxima. (Miellez.) In some respects this is yet a peerless flower-Queen of the Whites. Though introduced more than fifty years ago, it is almost impossible to supply the demand. Someone remarked at a great Boston show that if this flower was of a recent introduction it would be readily sold at $\$ 5$ a root. It stood well to the front with all the new and beautiful candidates for popular favor. It is an immense white flower with drops of carmine sprinkled in the center. An early bloomer and a good keeper..

L'Indispensable. A variety of unknown French origin, sent out from Holland, and greatly confused with Eugene Verdier. The two are entirely distinct, however, L'Indispensable being very much taller,

50500

$75 \quad 750$

75. 750 earlier, with differently formed flowers which are Each very full, globular, rose type. Lilac-white, shading to pale violet rose toward the center.

Lady Bramwell. Although of unknown origin, a splendid Peony. Beautiful early flower of glossy pink; very fragrant.

Louis Van Houtte. (Calot.) Rich, glowing purplish pink, tipped with silver; very brilliant coloring; fra-

$35350 \quad \begin{aligned} & \text { grant, medium-large flower............................ } \\ & \text { Mme. Chaumy. (Calot.) Globular; soft pink, much }\end{aligned}$ like Lady Bramwell, only larger and later. This is one of great beauty; a good keeper, but some seasons it needs shading from the hot sun.

Mme. de Verneville. (Crousse.) Very full bloom, sulphur-white, broad guard petals. Very beautiful, belonging to the front rank. One of the very best..

Meissonier. (Crousse) Globular; brilliant purplish red; slightly fragrant; free bloomer; stems long; habit of plant medium tall

Monsieur Barral. (Calot.) Very large, compact, rose type; uniform, pale lilac-rose; fragrant; free bloomer.

Mons. Jules Elie. (Crousse.) Immense, globular, fuli flower, imbricated rosiform; broad petals of finest, glossy, fresh pink, deeper tint at base of the petals, silvery reflex enveloping the whole bloom. Really a perfection Peony

Queen Victoria. Large, full, compact bloom, with fine, broad guard petals; opens flesh-white, center petals tipped with red blotches. One of the best cut-flower varieties, as it is an exceptional shipper and keeper.

Rosea grandiflora. Beautiful pale rose; large, globular flower; very fragrant.

Rubra triumphans. (Guerin.) Very early; bright purplish crimson; large flower. Often blooms single the first year

Van Dyck. (Crousse.) Large, globular, loose-crown flower; guard petals and center pure mauve, collar cream-white. Erect grower; blooming in midseason.
Doz. I $00 \$$ IO 00 $50 \quad 500$ 


\section{Flower Seeds for Autumn Sowing}

NOTE. For Perennial Flower Seed see our Midsummer Catalogue. Free on request

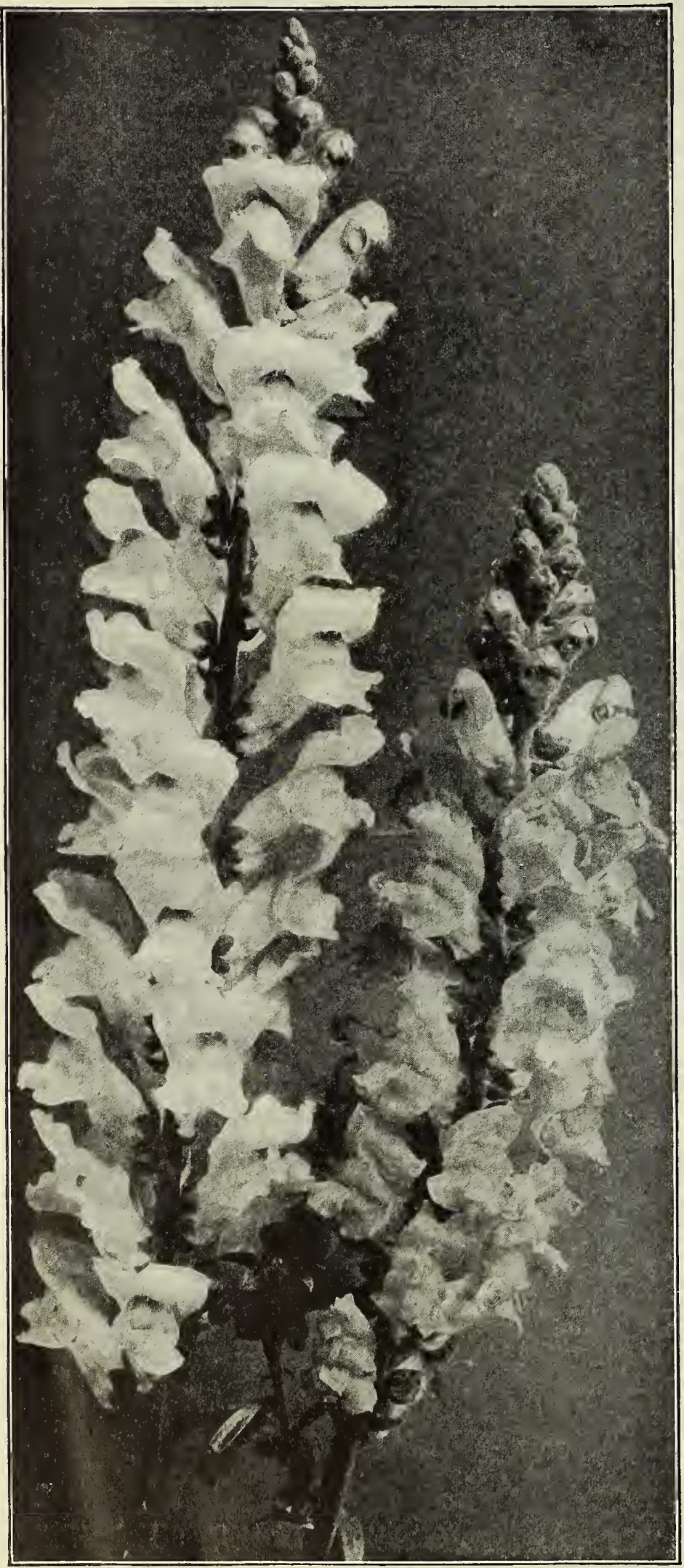

Antirrhinum, Giant-flowering

\section{ANTIRRHINUM (Snapdragon)}

\section{TALL VARIETIES}

Giant Coral-Pink. Very pretty and attractive shade. $\$ 0$ io $\$ 035$

Giant Blood-Red. Very beautiful shade........... Io 35

Giant White. Excellent cutting variety............. I0 35

Giant Yellow ....................... Io 35

Giant Queen Victoria. A very large white....... Io 35

Giant Rose Dore. A lovely new shade, a pretty self-

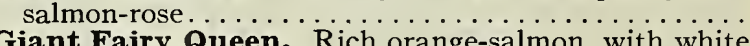

throat..................... Io 40

\section{DWARF VARIETIES}

Snowflake. New. Splendid pure white.......... $25 \quad 75$

Golden Queen. Yellow .................. Io 25

Queen of the North. White. An excellent bedding

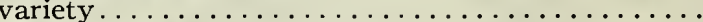

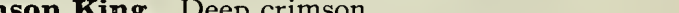

\section{ASPARAGUS}

Plumosus nanus. Graceful, fern-like foliage; grown extensively by florists for decoration. Full Greenhouse Grown. Pkt. 25 cts., I00 seeds, $\$$ I.

Sprengeri. Of more drooping and coarser habit; excellent for hanging-baskets. Pkt. $25 \mathrm{cts}$., oz. $75 \mathrm{cts}$.

\section{BELLIS PERENNIS (Double Daisy)}

Our strain of this popular flower is grown by a specialist in France, and for size cannot be excelled.

Pkt.

Giant-flowering Pink.

. \$o 25

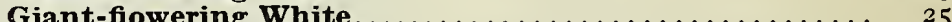

Double Red, Quilled .

Double Selected, Mixed.

\section{GALCEOLARIA}

The strains of this beautiful decorative pot-plant are grown by a famous English Calceolaria Specialist, and are the finest in existence.

S. \& W. Co.'s Giant Strain Pkt. S. \& W. Co.'s Giant Prize Strain ................ 50

Rugosa, Mixed. Shrubby. Small-flowering varieties for bed-

ding................................ 50

CALENDULA OFFICINALIS FL. PL.

$$
\text { (Pot Marigold) }
$$

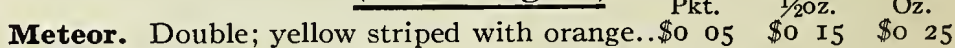
Prince of Orange. Similar to Meteor, but

much darker.

Sulphurea fl. pl.

$\begin{array}{lll}05 & \text { I5 } & 25 \\ 05 & 25 & 40\end{array}$

\section{CALLIOPSIS}

Drummondii (Golden Wave), Rich golden Pkt. 1/20z. Oz. yellow.......................... of $_{5}$ \$o 20 \$o 35

Tinctoria marmorata. Marbled yellow and brown..................... $05 \quad 20 \quad 35$

\section{CANDYTUFT (Iberis)}

Giant Hyacinth-flowered. Immense, pure white Pkt. Oz. spikes; when grown in rows for cut-flowers best results can be obtained only by setting the plants at least a foot apart in the rows and $1 / 2$ feet between the rows.......................\$o 25

Empress. Pyramidal, pure white............ Io

Queen of Italy. Light pink $\ldots \ldots \ldots \ldots \ldots \ldots \ldots$ Io

Lilacina. Beautiful large-flowering lilac.......... 05

Crimson. Bright crimson-red.

5
5
5




\section{CORNFLOWER (Centaurea Cyanus)}

If sown in September and thinned out to a space of 8 inches square, large flowers may be had

Emperor William. Well-known blue.......... Po $0_{5}$ \$o 25

Rose. Delicate rose................... 05

White. Pure white..................... $05 \quad 25$

Double Emperor William. A variety largely used by commercial florists on account of its large-sized

and double flowers...... I5 I 50

\section{GIANT SWEET SULTAN}

(Centaurea imperialis)

Our strains of Sweet Sultans are grown by a great many florists and gardeners, and are pronounced par excellence. Splendid for forcing under glass.

S. \& W. Co.'s Pure White. One of the best varieties Pkt. 1/40z.

for cutting; large and deliciously sweet-scented...... \$o ro \$o 35

Armida. Pink with white tinge.............. Io 35

Lilacina. Delicate lilac................ Io

Purpurea. Purple-rose.

Rosea. Brilliant deep rose

Io

35

35

\section{Four Fine Centaureas (For Greenhouse Growing)}

The following four varieties are largely grown by florists during the winter months for cut-flowers.

Suaveolens. (Yellow Sweet Sultan.) Very showy, Pkt. Oz. bright yellow flowers; sweetly scented............ \$o o5 \$o 60

Odorata. Beautiful large flowers of light blue, deli-

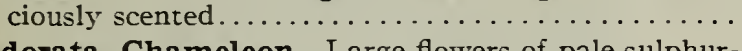

Odorata, Chameleon. Large flowers of pale sulphur-
yellow, changing to rosy lilac...................

Marguerite (Giant White Cornflower). Flowers 4

inches across, purest white and very fragrant...... Io I 00

\section{CINERARIA}

Seed should be sown from May to September where a succession is desired. When sown at this time, fine plants may be secured. The main point in the culture of Cinerarias is to secure as hardy a growth as possible with leaves of medium size. Seed may be transferred direct from seed-pans to thumb-pots. After planting, place in coldframe facing north, if possible. As pots become full of roots, shift to larger ones until flowering size is reached.

S. \& W. CO.'S GRANDIFLORA WHITE. Pkt.

S. \& W. CO.'S GRANDIFLORA FLESH

S. \& W. CO.'S GRANDIFLORA ROSE.

S. \& W. CO.'S GRANDIFLORA CRIMSON.

S. \& W. CO.'S GRANDIFLORA BLOOD-RED.

S. \& W. Co.'s Giant Prize Mixed. This strain of raria is grown for us by a famous English seed specialist. The flowers seldom measure less than 3 inches in diameter, comprising the following colors: White, rose, flesh, crimson, blue, violet, etc. The plants are of a very robust dwarf habit, which, combined with the mass of giant blooms, makes this strain exceedingly valuable.

S. \& W. Co.'s Stellata. Delicate star-like blooms are . \& . Co.'s Stellata. borne in great profusion on long stems, giving this variety a double use, as it is excellent for cutting as well as decorative purposes; all shades........

\section{MIGNONETTE (Greenhouse-grown)}

S. \& W. Co.'s Triumph. This Mignonette is one of the ing. In type similar to Allen's Defiance, except that spikes are more compact and the individual florets are much larger in size. Seed of this grand variety is grown at our greenhouses, and is saved from the best spikes. Pkt. $50 \mathrm{cts}$.

Allen's Defiance. A popular variety for indoor culture. Very fragrant; fine for cutting. Pkt. Io cts., oz. \$2.

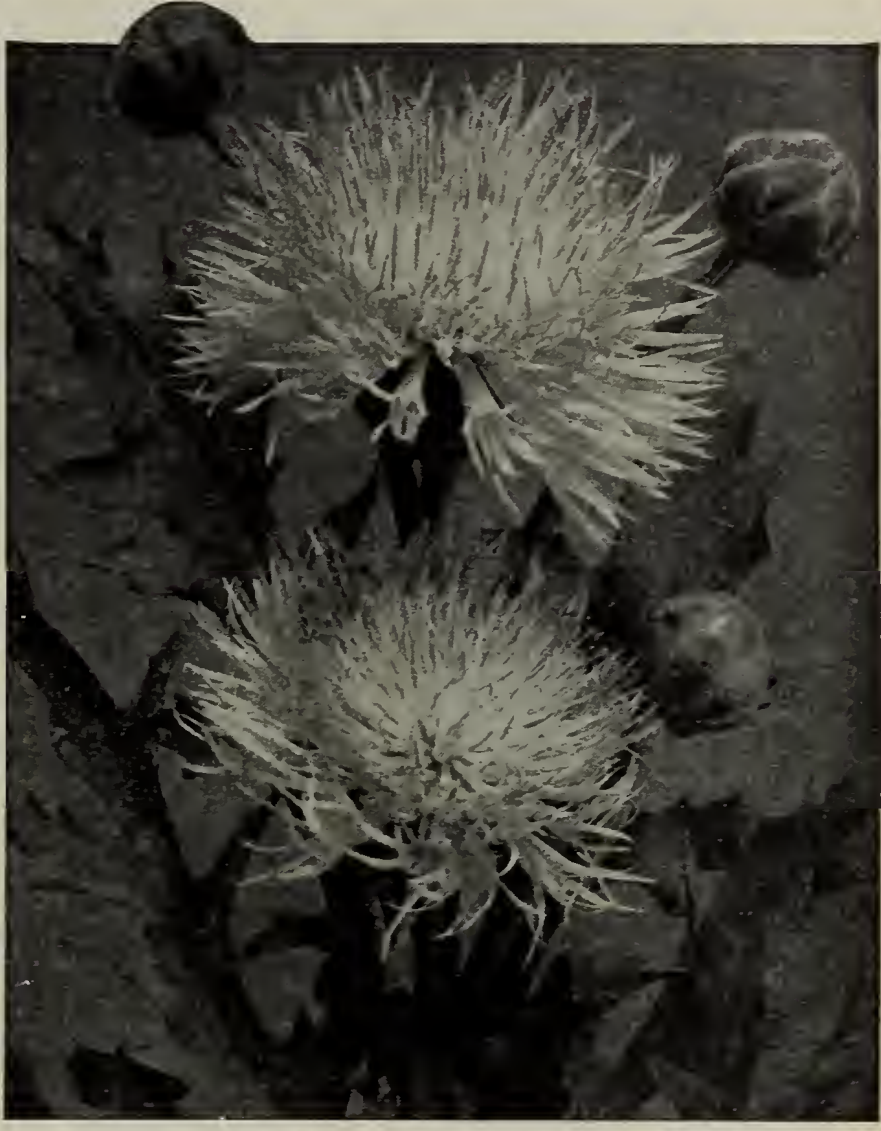

Giant Sweet Sultan (Centaurea imperialis)

\section{GIANT-FLOWERING CYCLAMEN}

Flowers of extraordinary size and of great substance. The leaves are proportionately large and beautifully marked. These are among the most beautiful winter-and spring-flowering plants for the window and greenhouse. Not only are the flowers of striking beauty, but the foliage is also highly ornamental. Sow seed from August to September, and do not permit the seedlings to become checked. When grown cool, most satisfactory results are obtained. Our strain is selected by a well-known English Cyclamen grower.

\section{S. \& W. Co.'s Giant Strain}

Giant Salmon-Red

Giant Rose

Giant Pure White

Giant Dark Red

Giant Lilac

Giant Cattleya Purple
Giant Rose-Salmon

Giant Pale Rose

Giant White. Red eye.

Giant Light Red

Giant White. Striped violet.

Giant Prize Mixed

Pkt. 25 cts., 100 seeds $\$ 1.25$

S. \& W. CO.'S Victoria. Beautiful, fringed, white and rose flowers. Pkt. 25 cts., IOO seeds $\$$ I. 50 .

\section{MYOSOTIS (Forget-me-not)}

All the varieties of these popular plants are very beautiful and general favorites with all; they succeed best in a moist situation. Half-hardy perennial. I $1 / 2$ feet.

Alpestris. A pretty trailer with blue flower ...... so 05 so 60 Eliza Fonrobert. Sky-blue. Victoria. Dwarf habit; sky-blue.

Oblongata perfecta. Flowers borne on long spikes; very suitable for winter blooming.

Palustris (True Forget-me-not)

Finest Mixed. semperflorens. Continuous bloomer.

Ruth Fischer. The latest and said to be the finest and largest-flowered Forget-me-not yet sent out, producing flowers up to $1 / 2$ inch in diameter, of true Forget-menot-blue; plants of strong, vigorous growth, of exceptional value for pot culture and spring bedding $\begin{array}{llll}0 & 05 & \text { SO } & 60 \\ \text { IO } & \text { I } & 00\end{array}$

25 I 50

IO I 25

IO 300

IO 250

0560 


\section{PRIMULA (Primroses)}

The strains of Primula offered below are specially grown for us by a famous English Primula specialist and are selected from the finest and best-developed plants. Seed sown in April will bloom during early winter; August for spring blooming. Sow in shallow pans, in soil consisting of part sand and leaf-mold worked through a fine sieve and allow for good drainage. Cover seeds lightly and water frequently; give a temperature of about 65 degrees.

\section{PRIMULA SINENSIS (Chinese Primrose)}

This beautiful Chinese Fringed Primrose is indispensable for spring decoration in the home or conservatory, and ranks as one of the most important winter-blooming pot-plants grown by the florist. Our Giant Fringed Strain is of the highest merit, and is carefully selected.

\section{Stumpp \& Walter Co.'s Giant Primulas}

Giant Magnifica, Blue

Giant Crimson

Giant Rose Queen

Giant Ruby Queen

Pkt. 75 ets.; collection of 6 pkts. $\$ 4.25$

Giant Double White

Giant Double Princess of Wales

Striped

Giant Double Blue

Pkt. 75 cts.; collection of 6 pkts. $\$ 4.25$

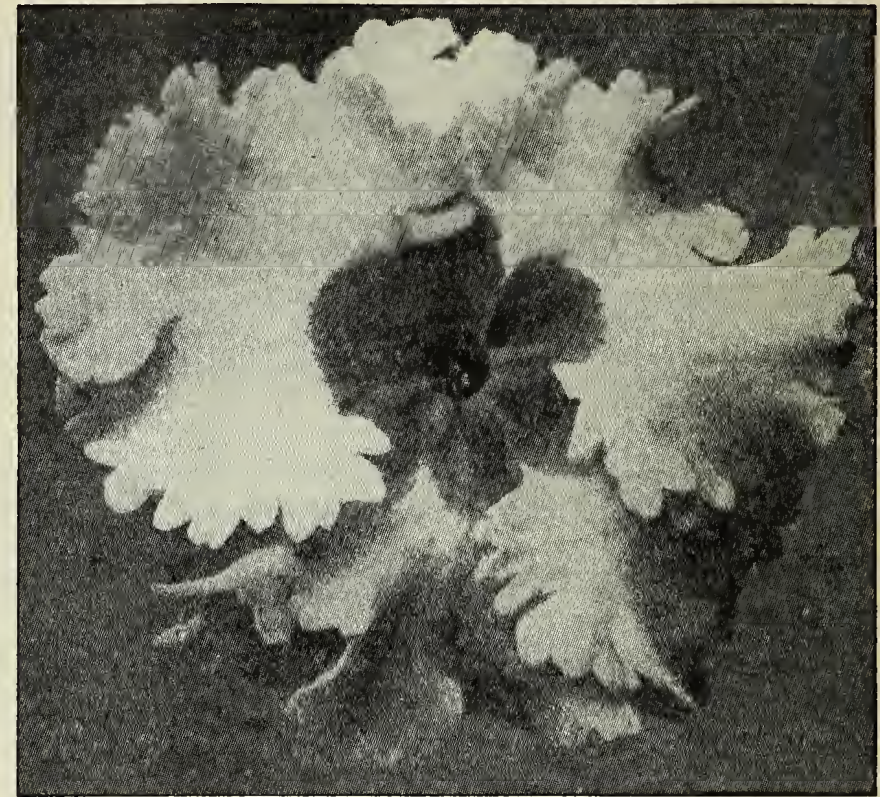

S. \& W. Co.'s Giant Primula

\section{PRIMULA OBCONICA GIGANTEA}

This type of Primula outrivals the old Obconica type, the flowers being considerably larger, often measuring $1 / 2$ inches in diameter. For pot culture this type is very useful, as well as for the open border.

Obconica gigantea Kermesina. Rich crimson..........\$o 25 rosea. Rose.................. ${ }_{25}$ alba...................
Obconica gigantea lilacina. Beautiful lilac ...........

Mixed. A mixture containing pure white

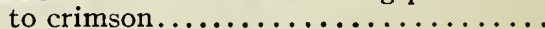

25

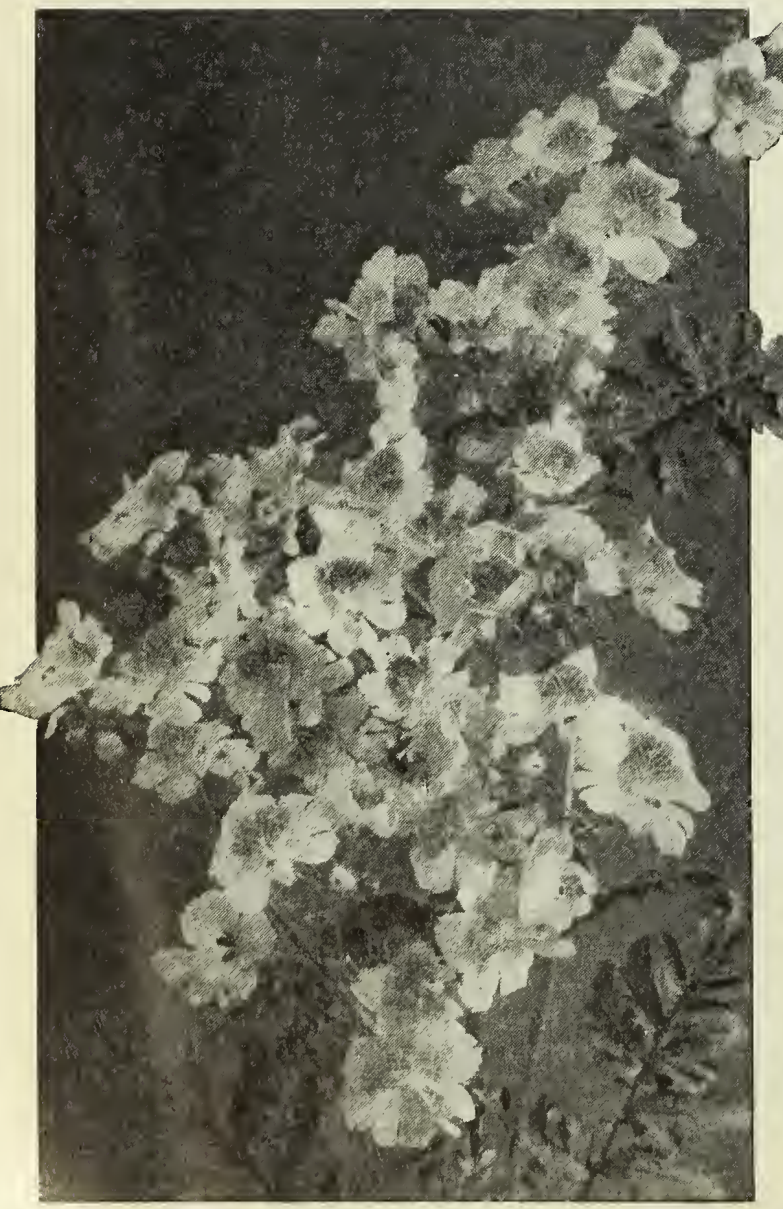

Schizanthus Wisetonensis

\section{PRIMULA STELLATA}

A very pretty form with large heads of star-shaped flowers of various colors; a splendid type for decorative purposes.

\section{Giant White Star Giant Salmon-Pink \\ Giant Crimson Star \\ Giant Rosy Star \\ Giant Mixed}

Giant Blue Star Gian
Pkt. 75 cts.; collection of 6 pkts. $\$ 4.25$

Forbesi (Baby Primrose). This is the freest-flowering Primula we know of. The little plants throw up tiny flower-stalks when only a few weeks old. These should be pinched off and the plants kept growing until October, and from then on until late in spring they produce their sprays of beautiful rosy lilac flowers in seemingly never-ending profusion. Pkt. $25 \mathrm{cts}$.

Kewensis. This new variety is most attractive, with pleasing bright yellow flowers borne on long stems. It is delightfully fragrant and stands well as a house-plant. Pkt. 25 cts.

Vulgaris(English Primrose). Canary-yellow, very fragrant. Pkt. Ioc., 1/4oz. 50c.

\section{SCHIZANTHUS}

\section{(Butterfly, or Fringe Flower)}

These dainty plants are of easy culture in any good garden soil. They are also useful as pot-plants for spring flowering, the seed being sown in early fall and the plants kept in a light house and given plenty of room as they need it.

Wisetonensis. Charming, new, long-blooming variety; multitudes of light- Pkt. colored flowers; excellent pot-plants. Carefully selected strain...........\$0 25 Hybridus grandiflorus. A magnificent new strain of this grand flower so much yod prized forting and as a pot-plani for conservatory decoration. This strain contains a multitude of the lighter coloss; and is the result of careful study on the part of a specialist in Europe. Of compact, pyramidal habit; very showy. Pkt. 25 cts.

Grahami. Red................................... I0

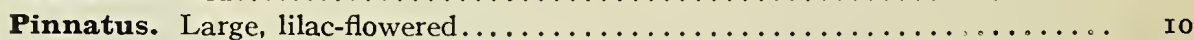

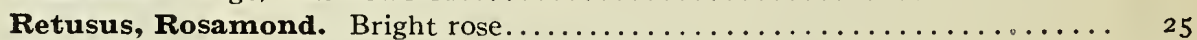

Retusus Trimaculatus. Rosy crimson, yellow lip................ ${ }_{25}$

Mixed ..................................... 10 FINEST PROCURABLE 


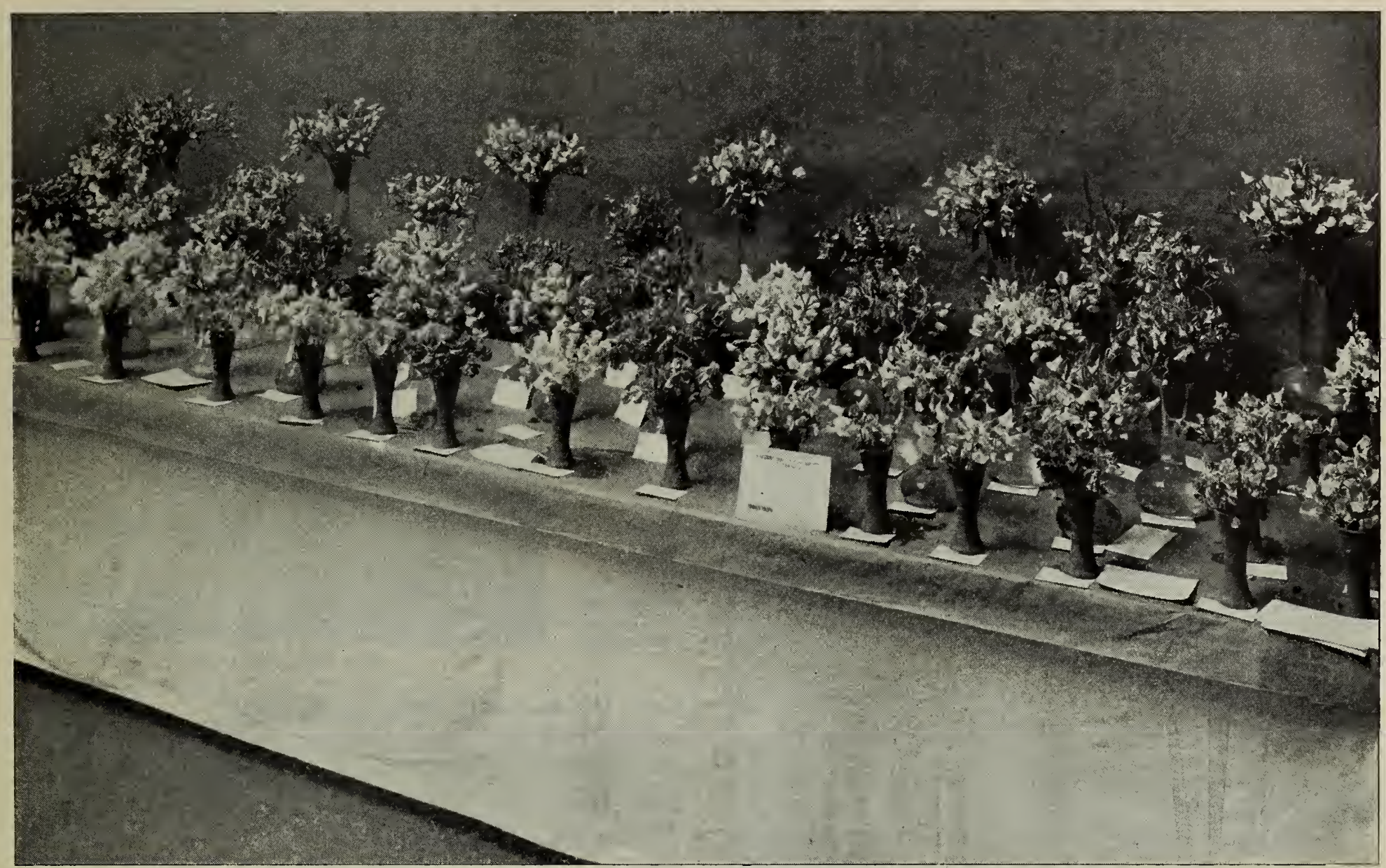

Our Collection of 55 Varieties of Spencer Sweet Peas at American Sweet Pea Society's Exhibition, held at Boston, July r3 and r4, r9r2

\section{SWEET PEAS FOR WINTER FLOWERING}

CUlturE.-A great mistake is often made in sowing Winter-flowering Sweet Peas too thickly. An ounce should be sufficient for a row 25 feet long; thin out to 3 inches apart. Sow the first week in September for Christmas flowering. For January, February or March, end of September. Best results can be obtained by maintaining a night temperature of $40^{\circ}$ to $45^{\circ}$, and $50^{\circ}$ to $55^{\circ}$ in the daytime. Spray vines frequently to keep down red spider, thrip and greenfly. Feed when plants are in full bloom.

\section{S. \& W. Co.'s Earliest White. The}

liest white on the market, often blooming in Pkt. Oz. $1 / 4 \mathrm{lb}$. six weeks from sowing................

\section{S. \& W. Co.'s Christmas Pink.}

If sown by September I under glass, flowers may be cut from Thanksgiving to Christmas.

\section{S. \& W. Co.'s Christmas White.}

This variety is grown very extensively by leading florists, and sold in large quantities. Companion to the popular pink.

Christmas Captain. Blue and purple......

Christmas Meteor. Scarlet.............

Earliest Sunbeam. Pale primrose-yellow....

Florence Denzer. Pure white.
Extra-Early Blanche Ferry. Extra-early Pkt. Oz. 1/4lb. strain of the popular pink-and-white variety.\$o Io $\$ 025$ \$o 75 Le Marquis. This is the same color as Princess

of Wales. Violet; large flowers............ Io 30 I 00 Mrs. E. Wild. Carmine, or dark pink....... Io 30 I 00 Mrs. Alex. Wallace. Bright lavender; a very popular sort.

Mrs. William Sim. Salmon-pink......... Io 10 . 30 I 00 Mrs. W. W. Smalley. Satiny pink........ Io 30 I Mrs. Hannan. Deep rose-pink of a very pleasing shade; medium flower........... Io 40 I 50 Mrs. F. J. Dolansky. Daybreak-pink...... Mrs. Charles Totty. Sky-blue; late........ Io 30 I 00 Snowbird. Early; white............. Io 30 I 00 W. J. Stewart. Bright blue............. Io 35 I 25 Watchung. Pure white; tall grower........ I0 30 I

\section{STOCKS, WINTER-FLOWERING}

BEAUTY OF NICE. Strong spikes with very large blooms; delicate flesh-pink. Pkt. 25 cts., $1 / 80 z$. $\$ 1$.

CANAR Y - YELLOW. Undoubtedly the finest yellow Stock yet raised; produces large spikes of beautiful, sweet-scented flowers on well-shaped plants. Wallflower-leaved foliage, similar to that of our well-known Cut-and-Come-Again, to which this variety makes a good companion. Height I 5 inches. Pkt. 25c., 5 pkts. $\$$ I.

CRIMSON KING. Excellent; tall habit; spikes often measuring I foot in length; flowers large and of a brilliant, fiery crimson. Pkt. 25 cts., $1 / 80 z$. \$I.
EMPRESS AUGUSTA VICTORIA. A grand winter Stock, considered as being the best of all the blue shades. Pkt. $25 \mathrm{cts}$. $1 / 8 \mathrm{Oz}$. \$I.

PRINCESS ALICE (Cut-and-Come-Again). Branching plant with double, pure white flowers on long, stiff stems; the best white for winter flowering. One of the finest for cutting. Pkt. 25 cts., $1 / 8 \mathrm{Oz}$. \$I.

QUEEN ALEXANDRA. A Stock that leaves little to be desired. Of grand, robust habit; comes almost all double, and of a beautiful lilac-rose. Pkt. 25 cts., $1 / 80 \mathrm{Oz}$. \$I. 


\section{PANSIES}

Pansies grow best in a cool, moist, but well-drained soil, enriched with wellrotted barnyard manure or ground bone (our No. 2 Bone being proper size).

For spring flowering, Pansies should be sown in July or August in frames and transplanted later.

It is poor economy to buy low-priced Pansy seed. To have good flowers, plant fresh seed full of vitality, the only kind we offer.

\section{FAMOUS NON PLUS ULTRA STRAIN Gigantic Size, Heavy Texture, Brilliant Colors}

Our Non Plus Ultra Pansy is a mixture containing the largest, handsomest and most perfect varieties ever sent out. The beautiful coloring and variety of marking give a bed of these Pansies a most brilliant appearance. The seed has been saved from the greatest assortment of types, including only the best of Giant Cassiers, Bugnots, Trimardeaux and Giant English, French and German strains. Finest Mixed, pkt. I 5 cts., $1 / 4 \mathrm{oz} . \$ 1.50,0 z$. $\$ 6$.

\section{GIANT PANSIES \\ Separate Colors}

Our strains of Giant Pansies are procured from specialists in Europe, who devoted their entire energies toward producing size, very heavy texture and strong stems, which can be accomplished only by a selection of the best plants for seed purposes, and therefore must not be confounded with strains offered by some seedsmen at lower prices.

Azure Blue. Violet-blue

Adonis. Light blue, white center

Blue. Bright blue.

Bugnot Strain. Large, stained, mixed

Cassier's Strain. All colors mixed.

Emperor William. Ultramarine-blue.

Fire King. Beautiful reddish yellow, brown center.

Faust. Black

\begin{tabular}{|c|c|c|c|}
\hline $\begin{array}{l}\text { Pkt. } \\
\text { \$o Io }\end{array}$ & $1 / 40$ & & $\mathrm{Oz}_{\$ 3}$ \\
\hline I0 & $\$ I$ & 00 & $\$ 3$ \\
\hline IO & I & oo & 3 \\
\hline 25 & I & 50 & 5 \\
\hline I 5 & I & Oo & 3 \\
\hline I 5 & I & 25 & 4 \\
\hline 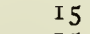 & I & 25 & \\
\hline I 5 & I & 25 & 4 \\
\hline
\end{tabular}

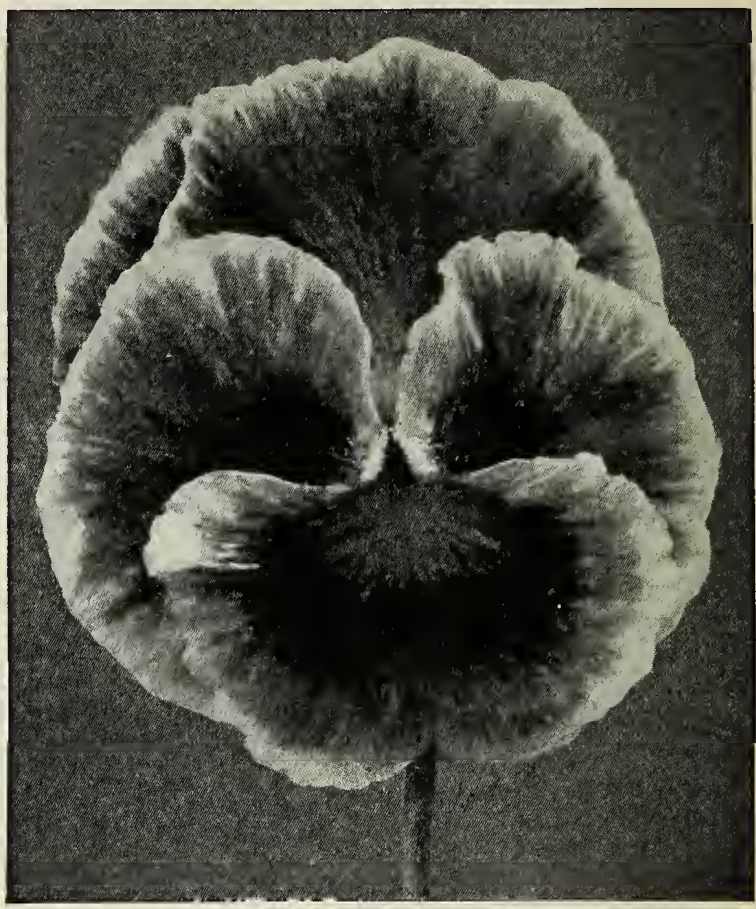

Non Plus Ultra Pansy shading to white................... President Carnot. White, each petal adorned with a deep violet blotch.............. I $5 \quad 200 \quad 700$ Purple. Deep purple................ Io 1 oo 350 Snow-white. Beautiful, glistening white..... White. White with dark eye............ Io I oo 350 Yellow. Pure yellow................ Io I oo 350 Yellow. With dark eye...........

\section{PANSIES IN MIXTURE}

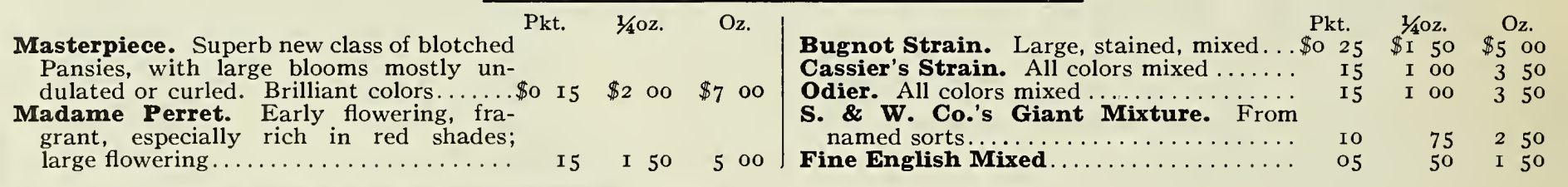

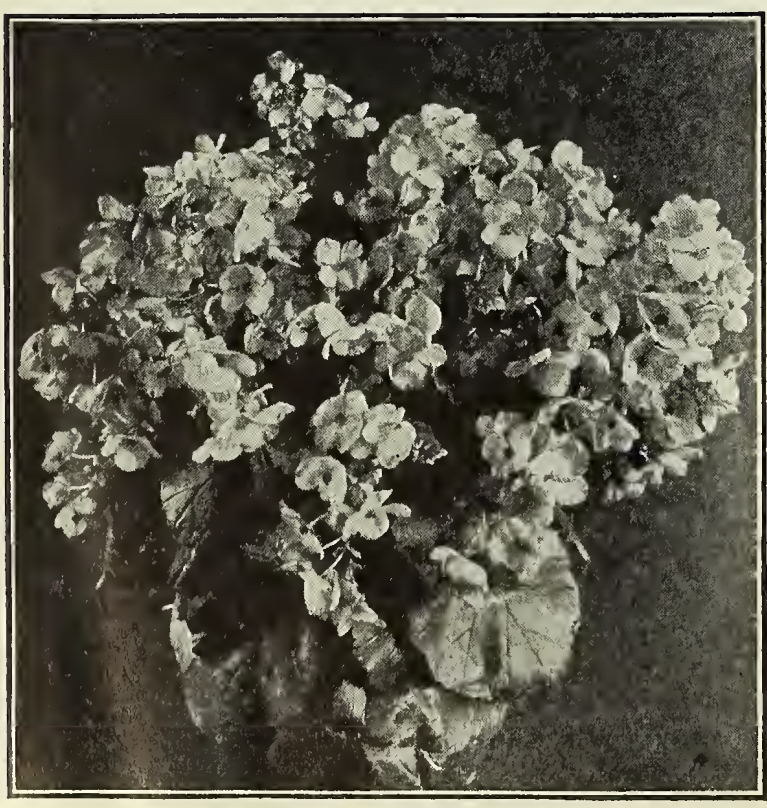

Begonia. Gloire de Lorraine

\section{FLOWERING PLANTS}

BEGONIA GLOIRE DE LORRAINE. Of all winter-blooming plants, Begonia Gloire de Lorraine is the most lavish in its production of flowers. From November to May the plants are so profusely covered with blossoms as to conceal the foliage. $21 / 4$-inch plants, $\$ 3$ per doz., $\$ 20$ per I00; 3 -inch plants, $\$ 4$ per doz., $\$ 30$ per 100.

S. \& W. CO.'S PRIZE STRAIN CINERARIAS. Our strain of Cinerarias cannot be surpassed for either size of bloom or beauty of color. They are grown from a famous English strain of seed and all are exhibition varieties. Selected plants, ready in October. I5 cts. each, $\$$ I.50 per doz., $\$$ Io per Ioo.

CYCLAMEN. White, Pink, Red, Crimson, White with Crimson base, Pink with Crimson base. 5 -inch plant, 60 cts. each, $\$ 6$ per doz.; 6 -inch plants, $\$ 1.25$ each, \$I2 per doz.; 7-inch plants, \$2 each, \$I8 per doz.

PRIMULA CHINENSIS. Large-flowering Varieties. Our strain of Primroses is conceded to be among the very best and is grown from seed furnished by a famous English Primula seed specialist. Selected plants, ready in October. 25 cts. each, $\$ 2.50$ per doz., $\$ 15$ per 100 .

\section{VIOLETS}

Marie Louise. Double. The finest double blue.

La France. Single. Rich violet-blue; a strong grower and very free flowering; deliciously scented.

Princess of Wales. Single. Soft violet-purple; very fragrant.

Price, any of the above Double or Single Violets, 20c. each, $\$ 2$ per doz., $\$ 12$ pex 100 . 


\section{Vegetable Seeds for Autumn Planting}

\section{BEANS}

Bountiful. One of the best flat, green-podded Bush Beans; very prolific and a continuous bearer from early spring to late fall. Absolutely stringless, tender and of delicious flavor. Pt. 20 cts., qt. 35 cts., 1/2pk. \$I. I 5, pk. \$2.25.

Triumph of the Frames. A good variety for forcing or early outdoor work. Produces a mass of pale green pods, tender and delicious. Pt. 25 cts., qt. 45 cts., $1 / 2$ pk. $\$ 1.50$, pk. $\$ 2.75$.

French Forcing Dwarf Emerald. Dwarf, prolific; especially suited for frame culture. Pt. 40 cts., qt. 75 cts., $1 / 2$ pk. $\$ 2.50$, pk. $\$ 4 \cdot 50$.

\section{BEETS}

Crosby's Egyptian. An excellent first-early variety-it produces roots of marketable size in shorter time than any other sort. This feature alone places it at the head of the list for growing in coldframes or greenhouses. After repeated comparative trials, we know that our type of Crosby's Egyptian Beet more nearly fills every requirement for the market-gardener's use than any other stock. Per pkt. 5 cts., oz. I 5 cts., $1 / 4$ lb. 40 cts., lb. $\$$ I.

\section{CARROTS}

Early French Forcing. The earliest variety and the one largely grown for forcing purposes. It makes a small, almost globeshaped root of an orange-red color. Per pkt. 5 cts., oz. I 5 cts., $1 / 4$ lb. 40 cts., lb. $\$$ I.20.

\section{GAULIFLOWER}

S. \& W. Co.'s Best of All, Earliest of All. Easiest grown, surest header. Of very dwarf, erect habit, with short outer leaves. Can be planted less than 2 feet apart each way. It is a sure header, every plant forming a large, solid, perfect head, of the finest table quality. Pkt. 25 cts., $1 / 4 \mathrm{oz} . \$ 2, \mathrm{oz} . \$ 7$.

\section{CUCUMBER}

\section{English Forcing Varieties}

S. \& W. Co.'s Improved Telegraph. A very dark green type of Telegraph Cucumber, which we have found, from our trials, to be superior of all other Telegraph varieties. Pkt. $25 \mathrm{cts}$.

Royal Osborne. Prolific and of deep, rich green color. Pkt. $25 \mathrm{cts}$.

Carter's Model. A very handsome variety, of fine form, with general characteristics of Tender and True, with the prolific habit and strong constitution of the Telegraph. Pkt. $25 \mathrm{cts}$.

Lord Kenyon's Favorite. A very fine variety. Pkt. 25 cts.

\section{LETTUCE}

Early Dumont. One of the best early varieties for planting in the open ground or under glass. It is rapid in development; tender, large size, outer leaves well folded in. The heads are of a clear, light green, the outer leaves slightly tinged brown and the heart clear yellow; delicately flavored. Pkt. Io cts., oz. 25 cts., $1 / 4 \mathrm{lb}$. 75 cts., lb. $\$ 2.50$.

Hittinger's Belmont Forcing. An improvement on the Boston Market; larger in size; crisp, and tender quality. Pkt. Io cts., oz. 25 cts., $1 / 4$ lb. 75 cts., lb. $\$ 2.50$.

Grand Rapids Forcing. An excellent loose-headed variety of superior table quality. Adapted to open-air culture or forcing in frames or greenhouses. The leaves are finely cut and of a beautiful pale green. Plants may be set quite closely together. Large heads and of delicate flavor. Pkt. $5 \mathrm{cts}$., oz. I $5 \mathrm{cts}$., 1/41b. $40 \mathrm{cts}$., lb. $\$$ I.25.

\section{SPINACH}

S. \& W. Co.'s New York Market. This Spinach grows rapidly and produces unusually large, thick, crumpled leaves. The best in flavor and the leaves are very tender. Pkt. Io cts., oz. 20 cts., $1 / 4$ lb. 50 cts., lb. $\$$ I.5O.

\section{TOMATO}

Sterling Castle. Superior for forcing or outdoor culture. Very heavy cropper; medium size. Pkt. I5 cts., $1 / 40 z$. 75 cts., oz. $\$ 2.25$.

Sutton's Winter Beauty. The plant is of strong constitution and bears with great freedom. Pkt. I5 cts., $1 / 4 \mathrm{oz}$. $75 \mathrm{cts}$., $0 \mathrm{oz} . \$ 2.25$.

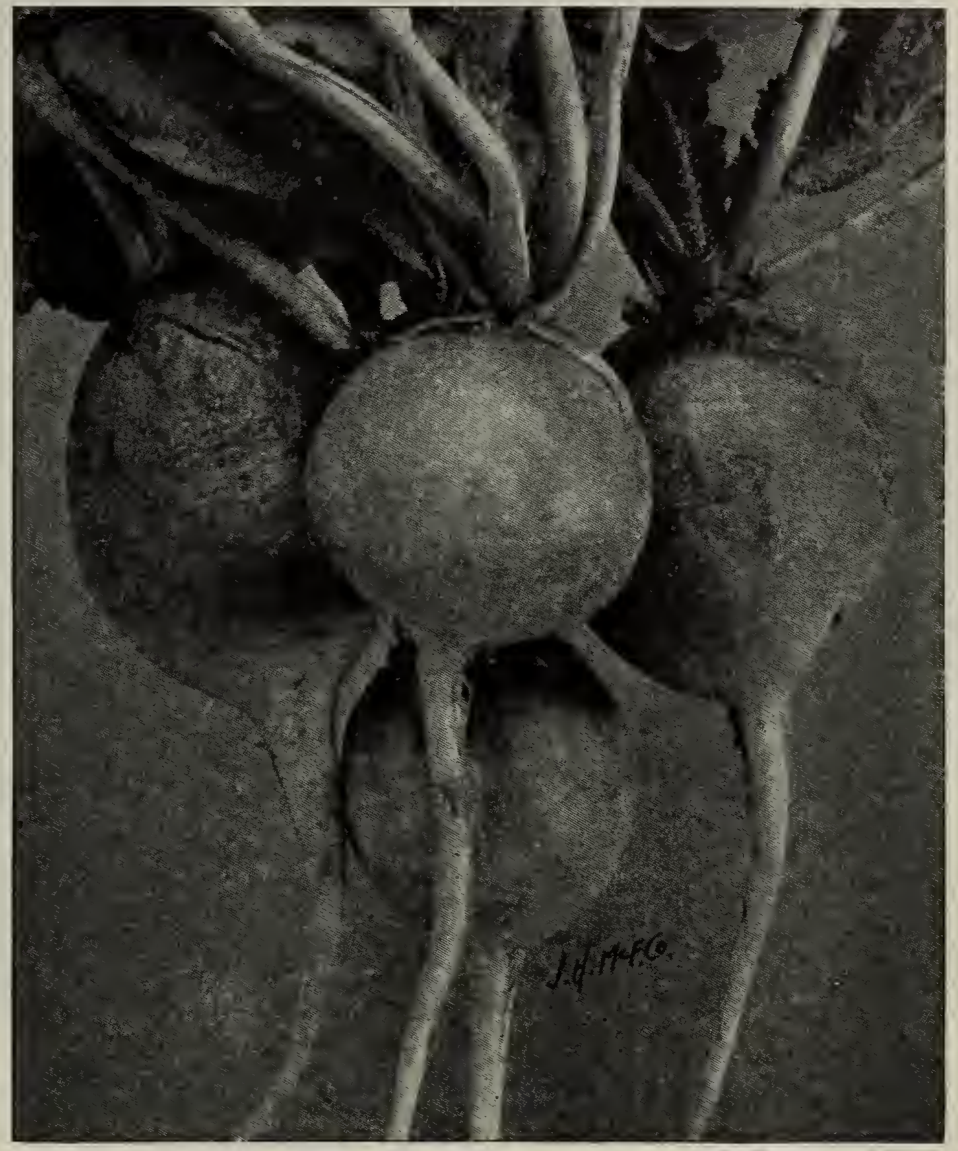

Early Scarlet Globe Radishes

\section{RADISH}

Triumph Scarlet-striped Forcing. A very desirable addition to our forcing sorts. The roots are about the size and shape of Scarlet Turnip White-tipped, but are creamy white, beautifully marked with spots and dashes of carmine. Pkt. Io cts., oz. I 5 cts., $1 / 4 \mathrm{lb} .40 \mathrm{cts}$.

Early Scarlet Globe. Of distinct shape, brilliant color, short-leaved, crisp and white; an excellent variety for forcing. Pkt. 5 cts., oz I 5 cts., $1 / 4$ lb. 50 cts., lb. $\$$ I. 50 .

French Breakfast. A favorite sort; mild and crisp. Pkt. 5 cts., oz. Io cts., $1 / 4$ lb. 25 cts., lb. 75 cts.

\section{ASPARAGUS ROOTS Ready in October}

Conover's Colossal, Columbian Mammoth White and Palmetto

I00 I 000

Selected One-year Roots, any of above varieties...\$o $75 \quad \$ 6$ oo

Extra-choice Two-year Roots, any of above varieties.

Mammoth Three-year Roots, any of the above

varieties......................2 0o I 5 oo

I 50 I0 00 FORCING CROWNS. These are extra heavy and are suitable for forcing under glass or in frames. Extra strong, $\$ 7$ per roo, $\$ 60$ per I, ooo.

\section{RHUBARB ROOTS Ready in October}

Giant Crimson Winter. This variety has become popular on account of its easily forcing qualities. Similar to Victoria in type. Large roots, 25 cts. each, \$2 per doz., \$I 5 per roo.

\section{SEA KALE (Crambe maritima)}

Sea Kale is almost unknown in America, but considered quite a delicacy in Europe.

Imported Extra-selected Forcing Crowns. $\$ 2$ per doz., $\$$ I $_{5}$ per I00, \$I 40 per I, 000. 

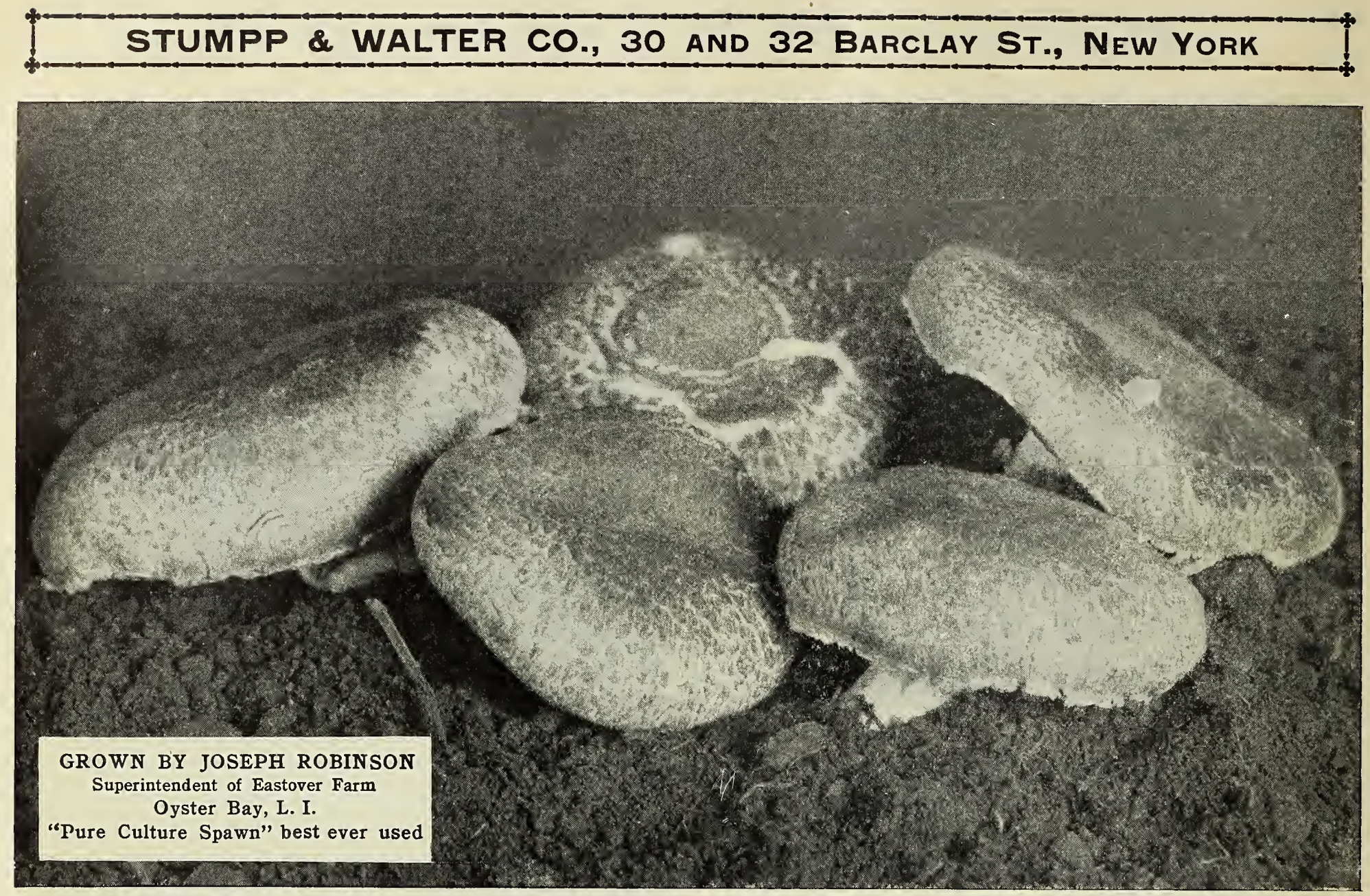

\section{S. \& W. Co.'s Pure Culture Mushroom Spawn}

Pure Culture is superior in size, quality and quantity of production; it is no longer an experiment; the best growers are using it

\section{Brief Cultural Directions by Mr. Robinson}

"I have the fresh horse droppings saved until a sufficient quantity accumulates to fill the beds, occasionally turning the manure and watering it slightly if it appears to be not moist enough. Then I leave the mass for three days, after which I again turn it, adding more water if necessary. After turning, I firm the manure, and in three days again repeat the operation. The most particular part is to get the manure moist enough and yet not too moist. After the second turning the manure is generally ready for the bed. My beds are only Io inches in depth. I press in the manure very firmly, and cover slightly with salt hay or straw, which tends to retain the moisture in the bed. When the temperature of the bed drops to $85^{\circ}$, I insert the "Pure Culture" Spawn in pieces about the size of an egg, I foot apart one way and 9 inches the other. I insert the Spawn just deep enough to cover with a little manure. I keep the temperature of the house between $55^{\circ}$ and $60^{\circ}$, and occasionally dampen the walls, etc., as required; also occasionally "dew" over the hay covering the bed with warm water. If the Spawn runs properly, a white, frothy substance will be observed in about ten days or two weeks. I then remove the hay and cover with one inch thickness of sifted soil, preferably good pasture loam, firming it down. Mushrooms will generally appear in from six to eight weeks. I always have a little finely sifted soil on hand, and fill all the holes up after gathering the Mushroomsthat is, the holes made by removing the stalks. With good care the bed will last three months. Should it appear dry, water thoroughly with water heated to $90^{\circ}$, in which a pinch of nitrate of soda dissolved will be found very beneficial. In conclusion, I may say I think most of the failures in Mushroom-growing arise from the manure being too dry." - Joseph Robinson.

\section{American Pure Culture Spawn}

10 lbs. will spawn 10 square feet

This type produces larger Mushrooms than the English, coming into bearing somewhat earlier, and continuing to crop for a long time. This spawn is produced by selecting spores from individual specimen Mushrooms, and is propagated and transferred to the bricks of manure, which, when planted, produce Mushrooms all of one type.

Per Brick (about I $1 / 2 \mathrm{lb}$.) $30 \mathrm{cts}$.

Per 25 Brieks, $\$ 5$.

Per 10 Bricks, $\$ 2.40$

Per 100 Bricks, $\$ 15$.

\section{Best English Spawn}

Fresh from a celebrated maker in England. Made in bricks of about I pound each

Per Brick (about I lb.) $20 \mathrm{cts}$.

Per 25 Rricks, \$3.75.

Per 10 Bricks, $\$ 1.80$. Per 100 Bricks, \$I 2 .

\section{Books on Growing Mushrooms}

Pamphlet (gratis for a postal card asking for it).

Mushrooms, How to Grow Them. By Wm. Falconer. The best and most practical American work on growing for home use or for market.........................

Mushroom Culture. By W. Robinson, England's standard authority on the subject........................... 50

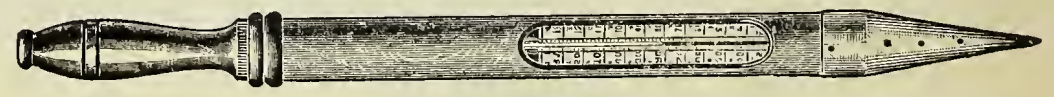

\section{Mushroom, or Hotbed Thermometers}

Heavy Brass Point style \$I.50.
All copper. Point may be removed and cleansed, $\$ 2$.

Thermometers should, whenever possible, be sent by express. 


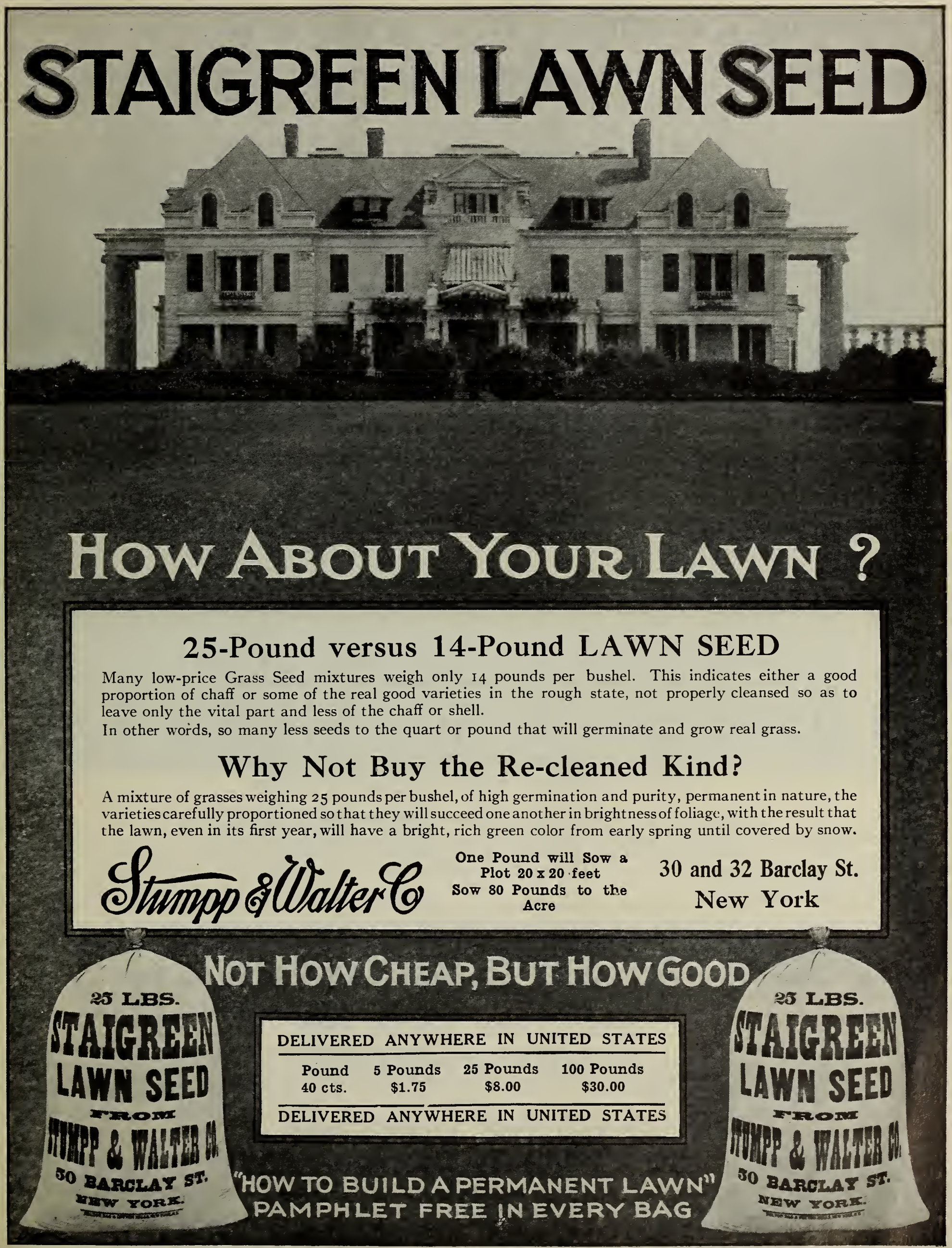




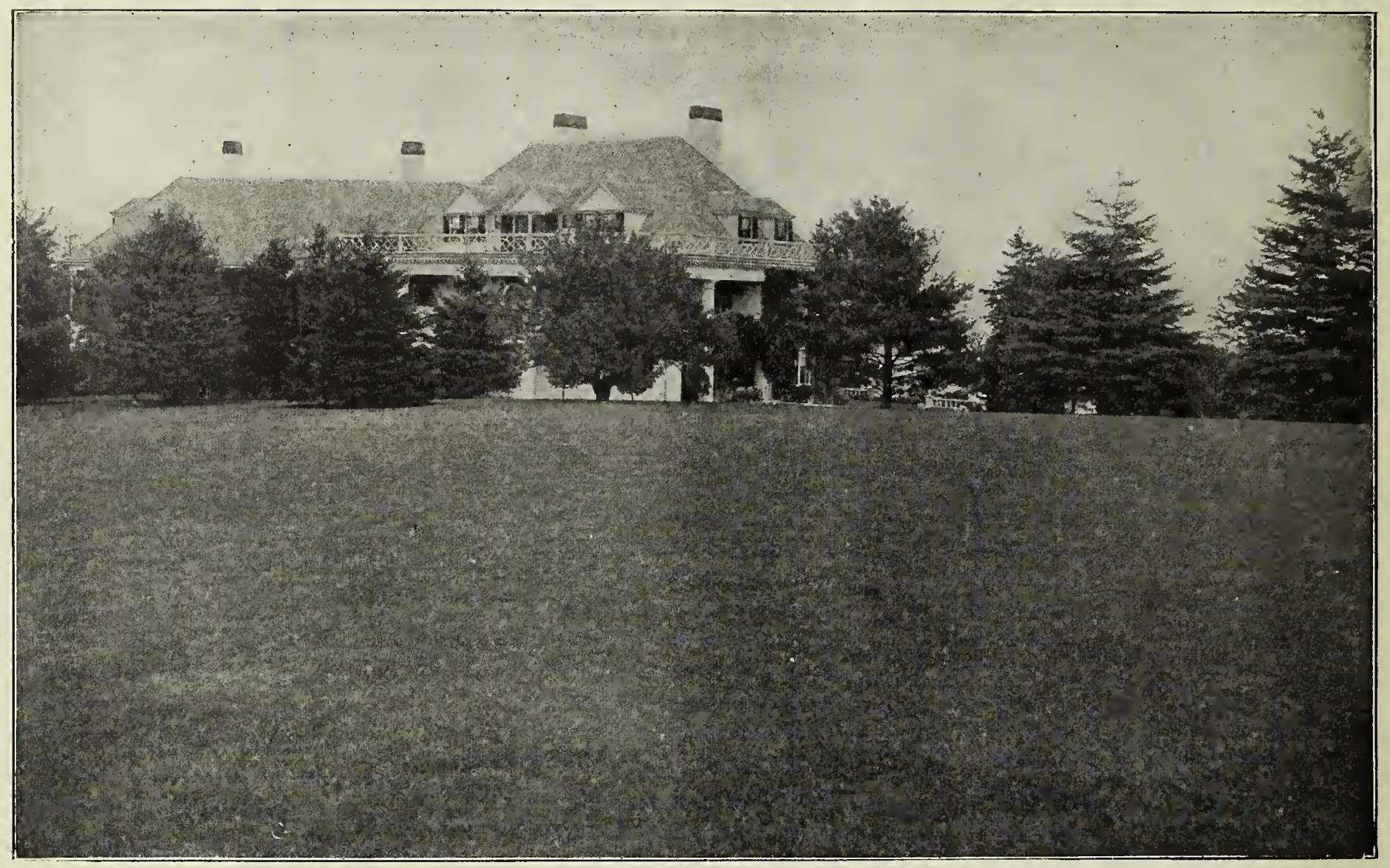

\section{STUMPP \& WALTER CO.'S}

\section{High-Grade Lawn Grass Seed}

\section{FOR LAWNS AND GRASS PLOTS} WEIGHS 22 POUNDS PER BUSHEL

Our "High-Grade" Lawn Grass Seed is composed of the very finest re-cleaned grasses, free from weeds and all foreign matter, and where a good quality Grass Seed is wanted, we recommend this grade of seed. While the price, \$5 per bushel, may seem high, remember our seed weighs 22 lbs. to the measured bushel, and requires only four bushels to the acre for new lawns, and one or two bushels for renovating old lawns.

Sow S. \& W. Co.'s "High-Grade" Lawn Grass Seed and you will obtain a beautiful, deep green lawn, which, owing to the varieties used in this mixture, will retain its velvety appearance during the entire summer.

One quart of our "High-Grade" Lawn Grass Seed is sufficient to sow about I 5 feet square; an acre will require four bushels. To produce a good lawn it is always best to sow the seed thickly.

\section{Price, qt. 25 cts., 4 qts. 85 cts., 8 qts. $\$ 1.50$, bus. $\$ 5,10$ bus. $\$ 45$ Shady Place Lawn Seed}

There is nothing more annoying in caring for a lawn than the bare, unsightly spots under the trees, shrubs, etc., and invariably all efforts have failed to get the grass to grow in such places; but by sowing this mixture the difficulties will be overcome. It is a combination of dwarf-growing varieties which will do well in all shaded/ places, being found in their natural state in woods and other sheltered spots. Qt. 35 cts., 4 qts. $\$$ I, 8 qts. $\$$ I. 75 , bus. (20 lbs.) $\$ 6$.

\section{Terrace Sod Lawn Grass}

To Grass a Bank or Terrace. For each square rod take two quarts of lawn grass seed and mix it thoroughly with 6 cubic feet of good, dry garden loam. Place it in a tub, and add liquid manure, diluted with about two-thirds of water, so as to bring the whole to the consistency of mortar. The slope must be made perfectly smooth, and then well watered, after which the paste should be applied, and made as even and thin as possible.

A special mixture of grasses best suited for sowing on terraces and side hills-grasses that produce strong, spreading roots, thus preventing heavy rains from washing them out, that will withstand drought and exposure, thrive on shallow soils, and at the same time produce a rich, green turf throughout the season. Qt. 35 cts., 4 qts. $\$$ I, 8 qts. $\$$ I. 75 , bus. (20 lbs.) $\$ 6$. 

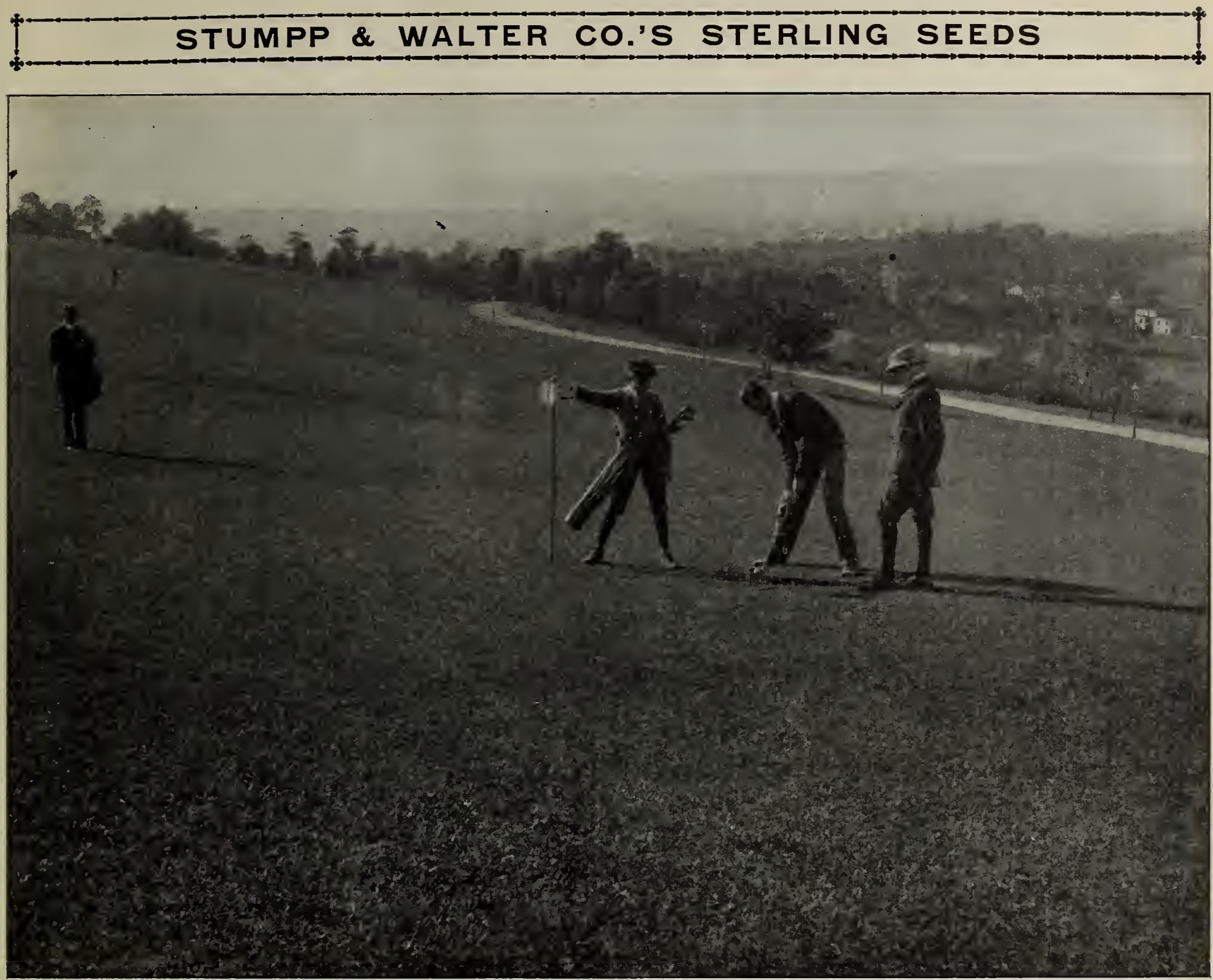

\section{Grasses for Golf-Courses}

When you buy Grass Seed for golf-courses, either for putting-greens, fair-greens, or outlying grounds, great care must be taken to select only such seeds as will do best for the purpose.

First. - See that you get the proper varieties, for very often grasses are sometimes used that are not fit to make the proper sod. This means disappointment in appearance, and endless work in trying to rid the greens of such grasses.

Second.-The quality of the seed. This should always be bought with the known germination and purity.

Third.- If your soil is sandy, clayey, moist or dry, this all makes a difference; and where seeding is done, it is always best to have only such grasses in the mixture as will give the best satisfaction. This information can always be obtained by consulting us.

Our Grass Seed Department is second to none; we always have in great quantities such valuable Grasses as Creeping Bent, Rhode Island Bent, Red Fescue, and all other varieties of Grass Seeds that are generally used on golf-courses, whether for puttinggreens, fair-greens, or outlying grounds.

\section{Putting-Green Mixture}

Composed of Creeping Bent, Rhode Island Bent, Red Top Re-cleaned, Fine-leaved Sheep Fescue, all of the very highest purity and germination. If for new work, or where the entire seeding of all greens is required, it would be best to consult us, and have us suggest the formula for the soil and location. Qt. 30 cts., 4 qts. $\$ 1.10,8$ qts. $\$ 2$, bus. (22 lbs.) $\$ 6.50,10$ bus. (220 1bs.) $\$ 62.50$

\section{Fair-Green Mixture}

The best-balanced, finest selection of Grasses, that will give an even, tough and lasting turf. We can supply a general good mixture that we know will give good satisfaction; but in cases when a lot of seeding is to be done we should like to supply a special formula, according to the requirements of the soil. Qt. $20 \mathrm{cts}$., pk. $\$ 1.25$, bus. (20 lbs.) $\$ 4.50,10$ bus. (200 1bs.) $\$ 42.50,50$ bus. or over, $\$ 4$ per bus. 


STUMPP \& WALTER CO., 30 AND 32 BARCLAY ST., NEW YORK

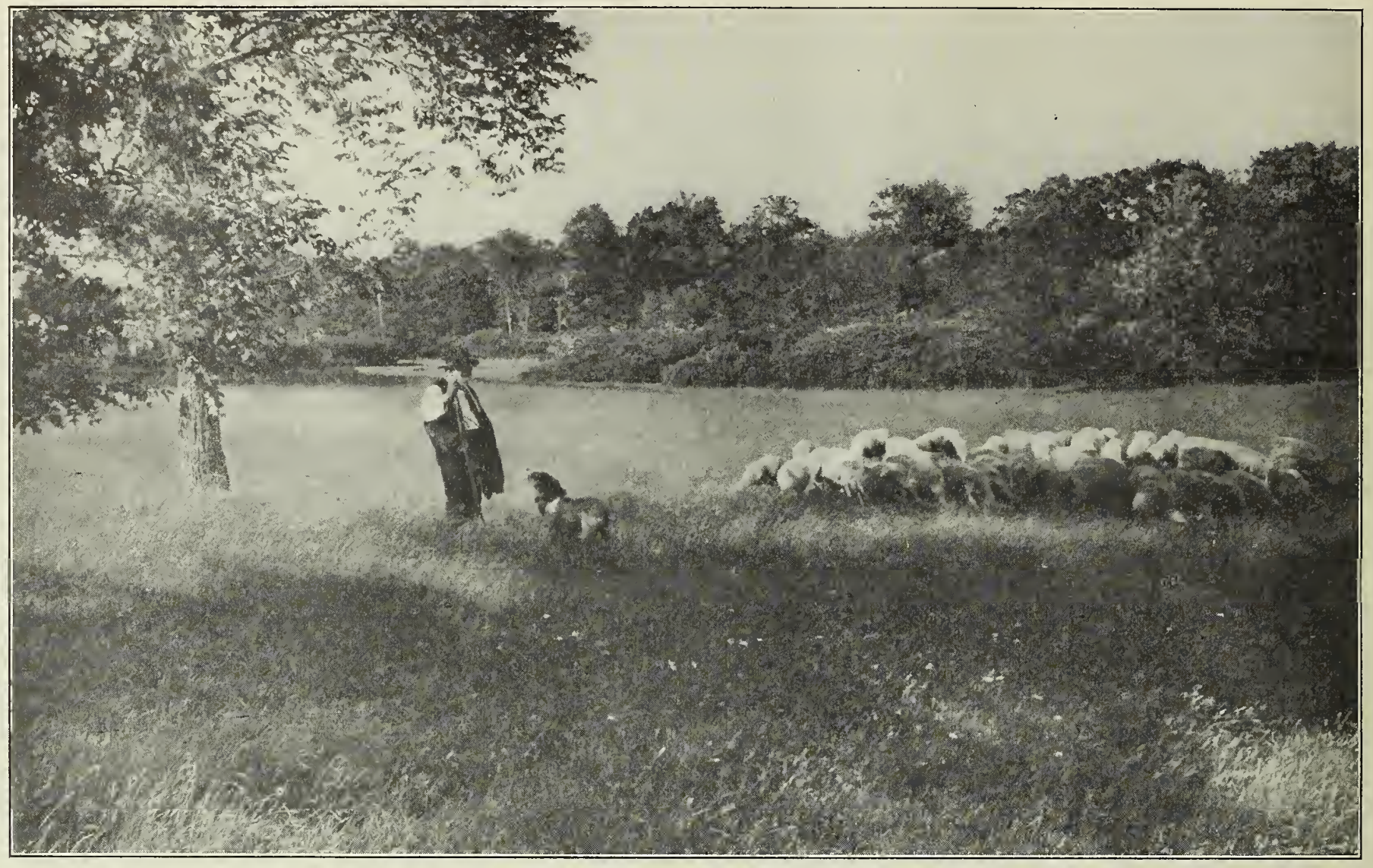

\section{GRASS MIXTURES FOR HAY AND PERMANENT PASTURE}

For every different kind and condition of soil there are a large number of grasses, either indigenous or introduced, which are especially suitable. Some sorts do best on high ground and in dry weather; others prefer plenty of moisture. Some mature so early and others so late that from the beginning of spring until winter sets in there is no time when one species or another is not at its best. From these considerations, the importance of sowing many varieties for pasture and meadow purposes will be apparent, consisting of the following varieties: Orchard Grass, Meadow Foxtail, Sheep's Fescue, Rhode Island or Creeping Bent, Hard Fescue, Sweet-scented Vernal (True Perennial), Meadow Fescue, English Rye Grass, Italian Rye Grass, Red Top, Timothy, Red and Alsike Clover, blended in proportions which we have found, from actual use, give the most satisfactory results.

On ordinarily fertile soil 80 pounds of this mixture are sufficient to seed an acre, but where the land is poor a larger quantity will be necessary.

For Hay and Permanent Pasture for Light Soils.

For Hay and Permanent Pasture for Medium Soils.

For Hay and Permanent Pasture for Heavy Soils.
For Orchard and Shady Places.

For Hay only. Specially recommended for large hay crop. For Pasture Only. Will stand close cropping without injury. $10 \mathrm{lbs} . \$ 2,80 \mathrm{lbs}$. $\$ 15$; in large lots, $\$ 18$ per $100 \mathrm{lbs}$.

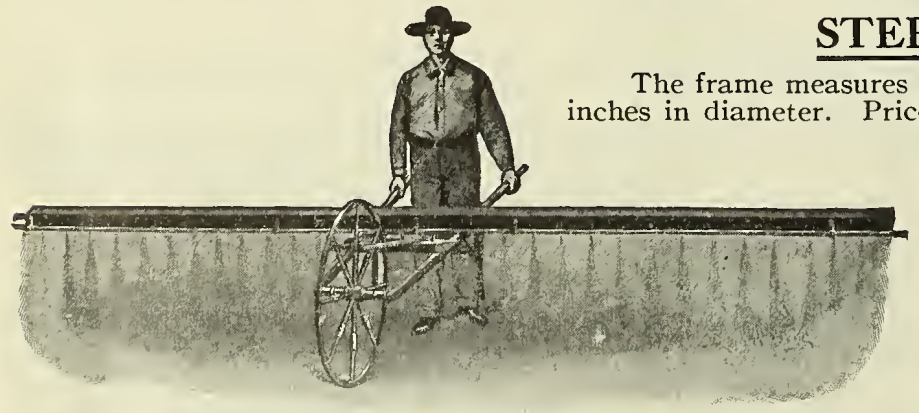

S. \& W. Co.'s Wheelbarrow Grass Seeder

\section{S. \& W. CO.'S WHEELBARROW GRASS SEEDERS}

(Weight, 45 to 50 pounds.)

On the market over thirty years and over 200,000 sold. For sowing all kinds of grass seeds broadcast, clover, timothy, alfalfa, Hungarian millet, rape and all small seeds. Also all chaffy seeds like red top, orchard grass, and clean blue grass, bent grass, any quantity per acre desired. They are no experiment, and are guaranteed to do an even, accurate, first-class job of seeding. Price (I 4 feet sowing area) \$10. 


\section{GENERAL LIST OF GRASSES}

Agrostis stolonifera. (True Creeping Best.) This is our very best grass for putting-greens, being hardy, Lbs, and the creeping habit of its roots, constantly adding to the size of its plant, forms the closest mat. Will
stand severe rolling and constant cutting. Should be in all lawn mixtures, but on account of its very high price, is rarely used. Our seed of this very valuable grass is of the highest germination and purity..... .

Agrostis canina. (Rhode Island Bent.) Except that this variety is of a more tuft-forming habit, it is very similar to the Creeping Bent. It is very difficult to find true Canina, and very often the ordinary Red Top is used for it. Our experience has been, that to get the very best seed of this variety is to import it from Europe. The seed that we offer has a purity of 70 per cent and germination of 80 per cent. This

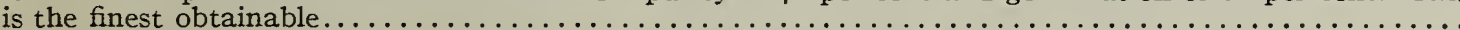

Agrostis vulgaris. (Red Top, Fancy.) Also known as English Bent. This grass, while being valuable as a lawn grass, is not so permanent as the preceding two varieties, very often sold as Creeping and Rhode Island Bent by dealers who have not given the proper study and interest in the different varieties. Our seed weighs 32 lbs. to the measured bushel, and has a purity of 95 per cent, and germination of 97 per cent, the very highest quality..

Agrostis vulgaris. (Red Top, Unhulled.) Vulgaris Choice. This seed is the same as the preceding variety, but is the natural seed as harvested, without being machined to remove the hulls, and is recommended for large seedings and mixtures. This seed rarely germinates more than 60 per cent, and our stock is always of the very highest quality........

Alopecurus pratensis. (Meadow Foxtail.) One of the most valuable varieties for permanent pastures.

Anthoxanthum odoratum. (True Sweet Vernal.) For field mixtures...

Avena elatior. (Tall Oat Grass.) A valuable grass for hay and permanent pasture mixtures...........

Avena flavescens. (Yellowish Oat Grass.)..........

Cynodon dactylon. (Bermuda Grass.) Valuable in the South for lawns.......................

Cynosurus cristatus. (Crested Dogtail.) An excellent grass for hard, dry soils; valuable for lawns in

Dactylis glomerata. (Orchard Grass.) A valuable grass for shaded pastures, and should be in all pas-

ture and hay mixtures...........................
Festuca duriuscula. (Hard Fescue.) A good grass for lawns and grazing pastures, where the soil is

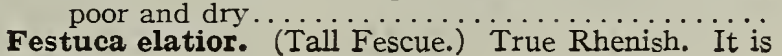

Red Top Grass one of the most valuable grasses to go in mixtures for hay $\ldots \ldots \ldots \ldots \ldots \ldots \ldots \ldots \ldots \ldots \ldots \ldots \ldots \ldots$. $\ldots \ldots \ldots$ light soils. It is Festuca heterophylla. (Various-leaved Fescue.) An even, tuft-forming grass, does well on light soils. It is
a very good grass for lawns, for which its line brush-like bottom leaves make it exceedingly fit.........

Festuca ovina. (Sheep, or English Fescue.) Does well on light, sandy soils, where other grasses have poor

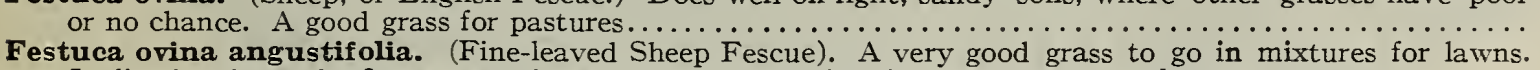
Inclined to burn the first season, but soon recovers and makes a very good turf the second year...

Festuca pratensis. (Meadow Fescue.) One of the best upper grasses for permanent pastures; yields an abundance of fodder of great nutritive value. Much liked by all kinds of stock....

Festuca rubra. (Red Fescue.) New Zealand-grown. A partly creeping, tuft-forming grass; it thrives on all sorts of soil, even on dry, sandy bottoms, and forms a rather thickly covered turf, leaving very little room for weeds to come through. It is also valuable for shady places in lawns, and has been found to do well under the shade of pine trees...

Lolium Italicum. (Italian Rye.) For quick growth, and to assist other grasses during the first year; used

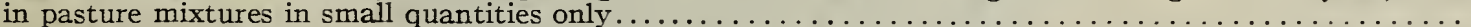

Lolium perenne. (English Rye.) Used for lawn mixtures where cheapness is the chief consideration,-. do not use for fine work.

Lolium perenne. (Pacey's.) Used the same as English Rye, but the seed is shorter-grained, and claimed by some to be more hardy than English Rye.

Phleum pratense. (Timothy.) For hay only.

Poa pratensis. (Kentucky Blue Grass.) One of our best grasses for lawn or field; does best when sown with other grasses.

Poa nemoralis. (Wood Meadow Grass.) Valuable for growing under trees, and our very best grass for shady

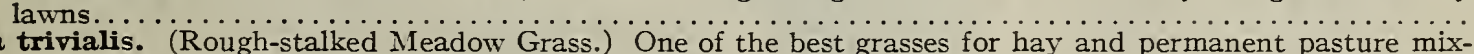
tures...........

\begin{tabular}{|c|c|c|c|c|}
\hline I8 & I5 & I & 25 & II \\
\hline ro & 70 & 6 & 00 & 50 \\
\hline to & 70 & 6 & 50 & 60 \\
\hline I 4 & 35 & 3 & 00 & 25 \\
\hline I4 & I 00 & 9 & 00 & 85 \\
\hline 36 & I 25 & IO & 00 & 90 \\
\hline 30 & 35 & 3 & 25 & 30 \\
\hline I4 & 40 & 3 & 00 & 25 \\
\hline 20 & 35 & 3 & 00 & 25 \\
\hline 22 & 65 & 5 & 00 & 40 \\
\hline I 5 & 45 & 4 & 00 & 35 \\
\hline I6 & 40 & 3 & 50 & 30 \\
\hline 22 & 50 & 4 & 50 & 40 \\
\hline 27 & 60 & 5 & 50 & 50 \\
\hline
\end{tabular}

$\begin{array}{rrrrrr}24 & 35 & 3 & 00 & 25 & 00 \\ 22 & \text { I2 } & \text { I } & 00 & 9 & 00 \\ 24 & \text { I2 } & \text { I } & 00 & 9 & 00 \\ 30 & \text { I5 } & \text { I } & 35 & \text { I } 2 & 00 \\ 45 & \text { I5 } & \text { I } & 20 & 8 & 00 \\ 2 \text { I } & 30 & 2 & 75 & 25 & 00 \\ 20 & 60 & 5 & 00 & 40 & 00 \\ 26 & 50 & 4 & 75 & 40 & 00\end{array}$

All our seeds are carefully examined as to purity and growth in our own laboratory and tested by the leading Seed Testing Stations, such as $Z$ urich (Switzerland), Hamburg (Germany), Paris (France), Washington, D. C.

The percentage of purity and growth are determined before we send out any seeds of any description from our establishment, and, in comparing prices, remember that we will furnish, on application, the percentage of purity and growth. We have only the very best qualities.

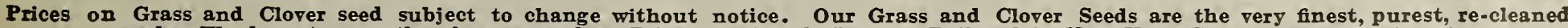
seeds. We do not carry the cheaper grades. Prices are 1.0 . b. Boat or Railroad in New York City; bags extra at cost 


\section{Selected Winter Seed Wheat}

Prices subject to market changes. Delivery f. o. b New York; bags extra at cost

\section{Jones' St. Louis Grand Prize (Beardless)}

This variety has proven itself to be adapted to all soils, doing well on light, sandy, clay loam, or river-bottom lands, and is also almost as entirely fly-proof as a wheat can be. A strong, vigorous grower, with dark, wide foliage. The straw is of medium length and very stocky; heads are square, compactly filled from base to tip, not extremely long, but the wide breasts running the length of the head encroach upon each other for room, and contain mostly four kernels each; color medium dark red, and of excellent milling quality. One of our customers reported a yield of 46 bushels to the acre; so many were the stalks and heads crowning them that if a hat were thrown in the field it would remain on top-the wall of wheat would not part to permit the hat to slide to the ground. Peck \$1, 1/2bus. $\$ 1.75$, bus. $\$ 3$, in $10-$ bushel lots, per bus. $\$ 2.75$.

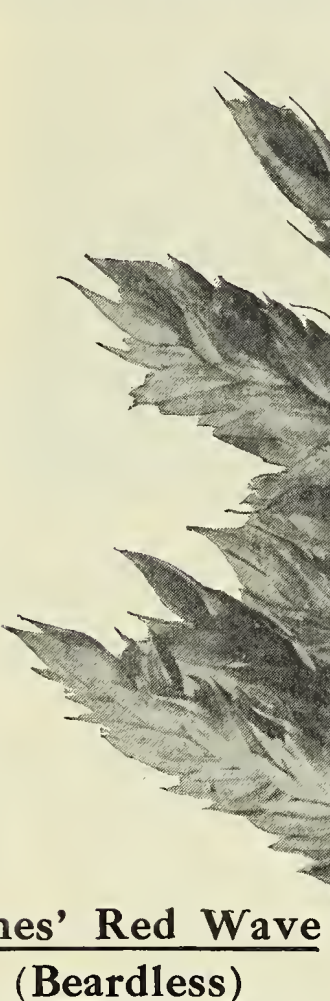

This grand Wheat has

fully maintained the good opinion expressed when first sent out in 1906. It is a cross between early Red Clawson and an unnamed crossbreed of Russian parentage. It is a bald Wheat with brown chaff; dark medium-long, large grain; heads very long and broad, filled with medium-long, large,

hard, dark kernels, rich in gluten. Straw golden; above medium height, stocky, very strong, thick-walled and not liable to go down; heads slightly leaning, hence not liable to sprout in the field. This variety last season gave a yield of 49 bushels and 2 pounds per acre in a field, the balance of which was sown to Dawson Golden Chaff that produced only 27 bushels per acre. Part of the first swath between the two going into the Dawson for fear of stray heads of Dawson; also raking adjoining, thus cutting the yield nearly a bushel. A plot on trial grounds $\mathrm{I} 1 / 2$ by 2 rods produced at the rate of 68 bushels and 5 pounds per acre. Pk. 80 cts., bus. $\$ 2.75$, in 10 -bus. lots, $\$ 2.50$ per bus.

\section{Harvest King (Beardless)}

Keeps right to the front among the standard varieties. If anything, this splendid, red-chaff, smooth variety stands higher even than it did several years ago. In the summer of I909, Harvest King wheat yielded at the Pennsylvania State Experiment Station 34.3 bushels per acre. Pk. 75 cts., lous. $\$ 2.35$, in $10-$ bus. lots, $\$ 2.25$ per bus.

\section{Fultzo-Mediterranean (Beardless)}

A cross of the "Fultz" and the old "Mediterranean." The berry is short, plump, red. Chaff white and smooth, without beards. The heads are medium length, very compact, well filled, inclined to widen at the top. Coming from two vigorous, hardy varieties, it is believed to have inherited the good qualities of both its valuable parents. "Fultzo-Med." has certainly proved itself a variety of extreme hardiness and great productiveness. Ripens early, stools well, the straw is of medium length to long, and so stiff that it will not lodge.

Pk. 75 cts., bus. $\$ 2.25$, in 10 -bus. lots, $\$ 2.15$ per bus.

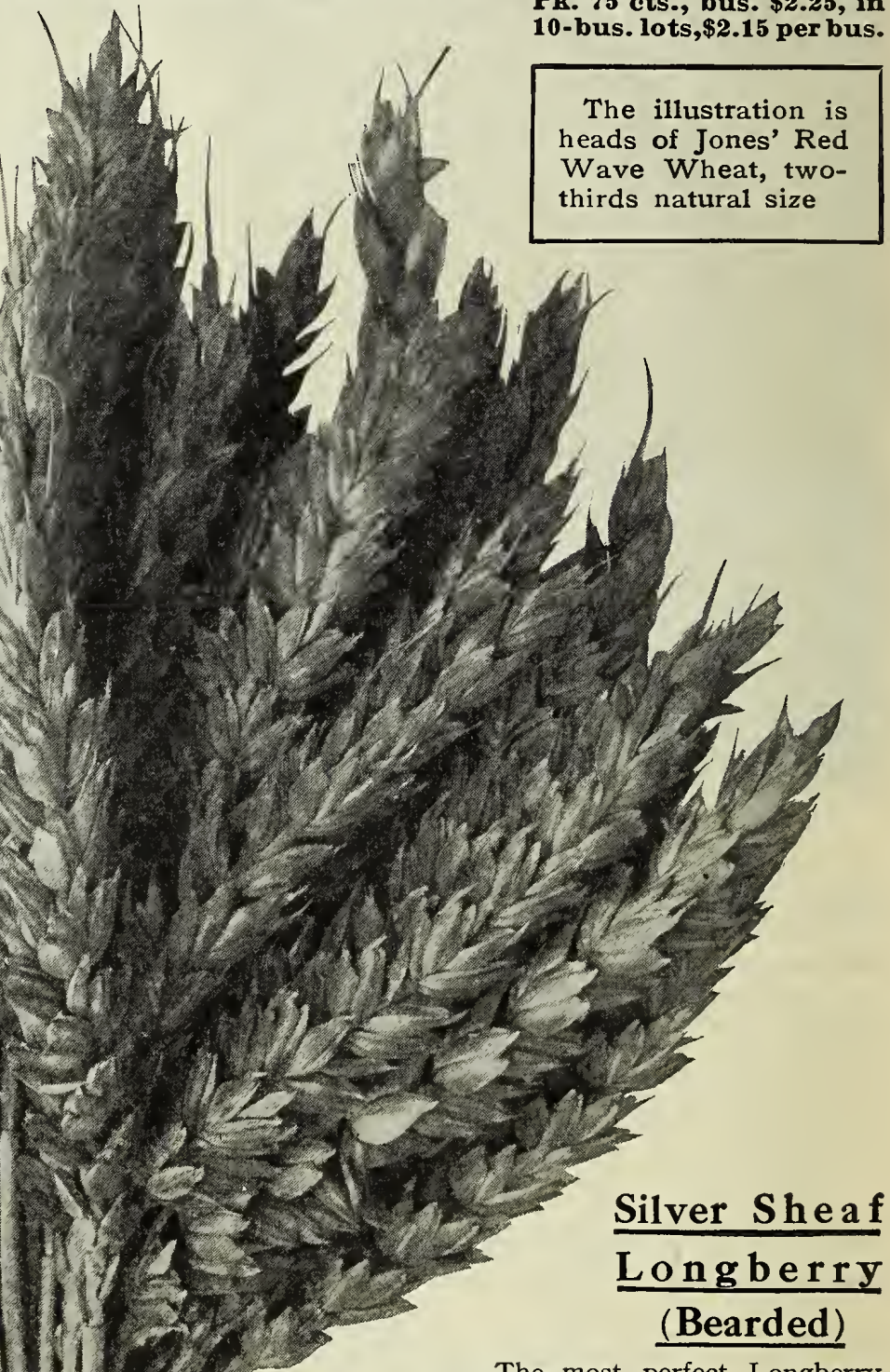

The most perfect Longberry Red Wheat grown, and will make a sensation among wheat growers and millers as soon as known. This marvel originated from a cross between the well-known American Bronze and a cross from Lancaster and a seedling Longberry. It is one of the hardiest of all Wheats, a strong, healthy grower and can be sown very late. If sown early, I 1/2 bushels of seed per acre will be enough on strong soil. Straw of light yellow, medium tall, thick-walled and strong; head long, wide and full; chaff thin and silvery white; grain large, dark and flinty, and nearly as long as rye kernels. It will command the highest market price of any Longberry yet grown, and will be the leading fancy milling Wheat of this country. Pk. 80 cts., bus. $\$ 2.50$, in 10 -bus. lots, $\$ 2.40$ per bus. Seamless bags 22 cts. extra for each two bushels.
Jones' Red Wave 


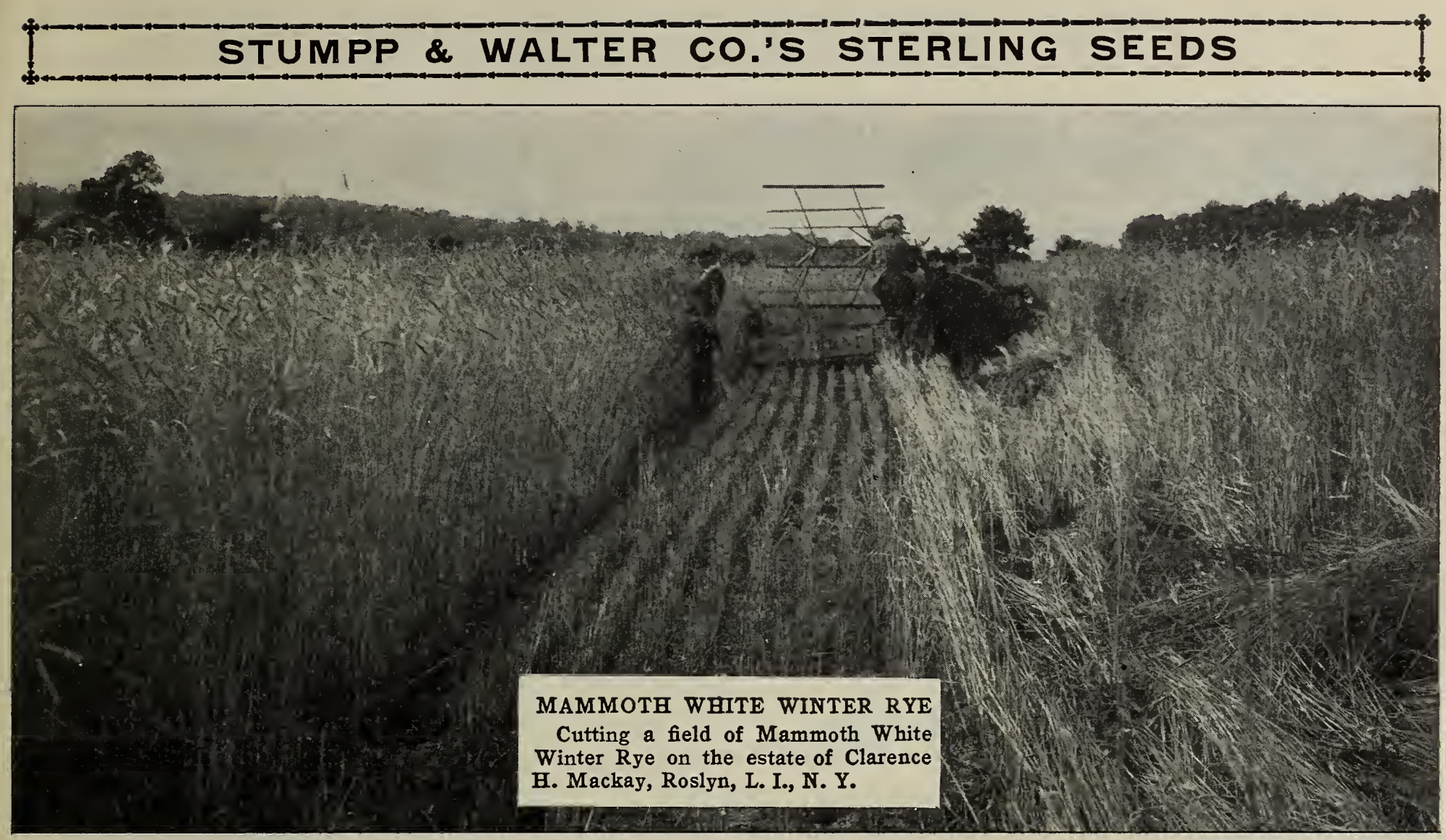

\section{SEASONABLE FARM SEEDS}

Prices f. o. b. Boat or Railroad, New York, and are subject to market changes

\section{MAMMOTH WHITE WINTER RYE}

Unquestionably the heaviest cropping Rye in existence, having in fair tests outyielded all other varieties both in straw and grain. The heads average 6 to 8 inches in length and are filled from end to end with large, plump, heavy grains. The straw is giant in length and strength and of extraordinary stiffness, resisting severe wind and rain-storms to a remarkable degree without lodging. Bus. $\$ 2$, in 10-bus. lots, $\$ 1.90$ per bus.

\section{RE-GLEANED ALFALFA}

\section{Now is the time to sow}

Sow 30 to 40 pounds per acre if broadcasted, or 25 to 30 pounds if drilled in in May, or during August and early September, or most any season when weather conditions are favorable, top-dress it with manure every fall, and it will rarely winter-kill. It can be cut usually three times in one season. The great secret in getting a successful stand of Alfalfa lies in the preparation of the ground; it will pay everyone who wants to grow this valuable farm-crop to give the ground preparation most intelligent thought. It must be borne in mind that an Alfalfa field properly started will yield successfully a score of years. Ask for our Pamphlet on Alfalfa, mailed free. Lb. 30 cts., 10 lbs. $\$ 2.75,100$ lbs. $\$ 25$.

\section{VARIOUS CLOVERS}

Alsike, or Swedish (Trifolium hybridum). Hardiest of all Clovers, and on rich, moist soil yields an enormous quantity of hay or pasture. Lasts many years. Sow Io lbs. per acre when used alone. Lb. 50 cts., 10 lbs. $\$ 4,100$ lbs. $\$ 35$.

Crimson or Scarlet Clover (Trifolium incarnatum). It can be seeded at any time from June to October, at the rate of I5 to 20 lbs. per acre, and makes the earliest possible spring pasture, blooming the latter part of April or May, and, for feeding as hay, should be cut just before coming into full bloom. Sow Crimson Clover at the last working of all crops, like beans, corn, melons, cucumbers, tomatoes and other crops. Lb. 15 cts., 10 lbs. $\$ 1.20,100$ lbs. $\$ 10$.

Red Clover, Medium (Trifolium pratense). Medium Clover. The leading variety of Clover for pastures or meadows. Finest quality. Sow 20 pounds per acre alone, or 15 pounds where other grass or hay crops are standing. Lb. 50 cts., 10 lbs. $\$ 4,100$ lbs. $\$ 35$.

white Dutch Clover (Trifolium repens). The best variety for lawns, as it forms a close herbage and remains green throughout the season. Lb. 60 cts., 10 lbs. $\$ 5.50,100$ Ibs. $\$ 50$.

All Farm Seeds listed on this page are furnished in seamless ba

\section{RE-GLEANED TIMOTHY}

Our stock of this is unusually large and of very good quality. Sow 25 pounds per acre alone, or I5 pounds with wheat or grasses. Lb. 15 cts., 10 lbs. $\$ 1.20,100$ lbs. $\$ 8$, bus. $\$ 4.50$ (45 lbs).

\section{WINTER VETCH (Vicia villosa)}

\section{True Sand or Hairy Vetch}

Extensively used as a soil renovator or for dry or green feed in the early spring. It may be sown alone or with winter rye or oats; is perfectly hardy, thriving in every climate, under most adverse conditions. Is very nutritious and live-stock relish it. When sown with rye, etc., it will attain a height of 4 to 5 feet; it requires one-half bushel to sow an acre, or one bushel if sown alone. Sow as early as possible in the fall or summer and get a good growth before cold weather sets in. 60 lbs. per bushel. Lb. 12 cts., 10 lbs. $\$ 1.10,100$ lbs. $\$ 10$, bus. $\$ 6.50$.

\section{FARMOGERM}

\section{High-Bred Nitrogen-Gathering Bacteria}

Inoculate your Alfalfa with Farmogerm. Acre size, \$2; 5-acre size, \$9. See article in "Practical Farmer," issue of July 6, I9I 2.

"Hundreds of our readers will probably start growing alfalfa on their farms this year for the first time. Of course, they want it to be successful; but, remember this-alfalfa does its best in the dry sections of the West. To make it do well in the other parts of the country it needs a little boosting. Now, if you believe in alfalfa enough to give it a trial, give it the best chance you know how. For $\$ 2$ you can secure enough alfalfa bacteria to inoculate sufficient seed to sow one acre; this is worth while. Two years ago the editor purchased some alfalfa bacteria from the Earp-Thomas Farmogerm Co., of Bloomfield, N. J., and is well pleased with the result. This firm also manufactures bacteria cultures for cowpeas, clovers, soy beans and other legumes."

We can supply you with the Farmogerm quoted above; descriptive matter on request.

Farmogerm furnished in acre size (sufficient to treat seed for one acre), $\$ 2 ; 5$-acre size, $\$ 9$.

bags, for which a charge of 22 cts. for each two bushels is made 


\section{Miscellaneous Garden Supplies}

Asparagus Buncher, "Acme." No. I makes bunch 3 to $3 \frac{1}{2}$ in. diameter, length adjustable 7 to 9 in.; No. 2 makes bunch 4 to $4 \frac{1}{2}$ in. diameter, length adjustable 7 to 9 in. $\$ 2$.

Asparagus Knives. English Saw-tooth, \$I; American V-Shaped, 30 cts.; American Straight Edge, $30 \mathrm{cts}$.

Baskets, Rustic Hanging. Unexcelled for style, finish and durability.

Each Doz.

-inch........ I I 5 II 50

Io-inch ........... I 50 I5 00

I I-inch......... I 60 I6 oo

Baskets, Wire Hanging.-Heavily

8 -inch........\$o 50 Each $\$ 5$ oo

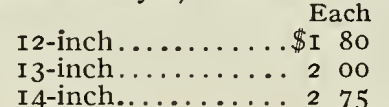

I4-inch........... 275

I5-inch........ 285

Doz.
$\$ 18$ oo

Io-inch........... 60 60 60

nstructed.

I2-inch

$\ldots \ldots \ldots$ Each

Baskets, Imported English Garden--

Length Width Each Doz.

No. 2. II $1 / 2$ in. 6 in... $\$ 040 \$ 450$ No. $6.20 \frac{1}{2}$ in. $10 \frac{1}{2}$ in.. $\$ 090 \$ 10$ oo

No. 4. 15 in. $8 \frac{1}{2}$ in.. 60675 No. 8.26 in. I4 in.... I 25 I 4 oo

No. 5. I $7^{1 / 2}$ in. $9 \frac{1}{2}$ in.. 75850 No. 9. 28 in. 15 in.... I 50 I 700

Baskets, Orchid- Doz. 100

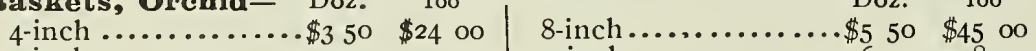

5 -inch ...........4 4 oo 2750 Io-inch........... 65048 o0

6 -inch ...........4 50 3I 50 | I2-inch........... 750 56 00

Boxes, Cardboard, Flower (Green, lock corners)-

Depth Length Width" roo Depth Length Width roo

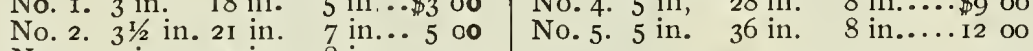

No. 3. 4 in. 24 in. 8 in... 7 oo

Boxes, Violet. No. 5. 8 in. deep, I in. long, $5 \frac{1}{2} \mathrm{in}$. wide, $\$ 7$ per Ioo; No. Io. 6 in. deep, 9 in. long, 5 in. wide, $\$ 5$ per Ioo.

Boxes, Corrugated Cardboard. Very heavy and durable; extensively used by florists for shipping cut-flowers.

No. Length Width Depth Doz. Ioo No. Length Width Depth Doz. Ioo

A. 20 in. 7 in. 4 in. $\$$ I $20 \$ 9$ oo D. 36 ill. I4 in. 8 in. $\$ 3$ oo $\$ 22$ oo

B. 28 in. 8 in. 5 in.. I 5011 oo E. 48 in. I4 ill. 8 in. 35028 oo

Carnation Supports. Model Extension, 2-ring, 50 cts. per doz., $\$ 3$ per

Ioo; 3-ring, $60 \mathrm{cts}$. per doz., $\$ 3.50$ per 100 .

Clips, Eureka. For fastening rose and chrysanthemum wire stakes. $75 \mathrm{c}$. per box of $500, \$ 1.40$ per box of 1,000 .

Corn Knife. For cutting corn stalks or heavy grass. 35c. ea., \$3.5o per doz.

Dibble, Garden. For transplanting cabbage, celery, etc. Small size, steel point, $35 \mathrm{cts}$; larger size $40 \mathrm{cts}$; large size, brass point, $60 \mathrm{cts}$.

\section{Flower Pots, Pans, Vases, Saucers and Stands}

Flower Pots Standard. Best on the market.

Doz. Ioo Doz. $\quad$ I 00

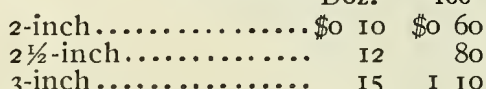

3 -inch $\ldots \ldots \ldots \ldots \ldots \ldots$ I5 I 10

4 -inch............ $35 \quad 200$

$\begin{array}{ll}5 \text {-inch } & 270 \\ \text { Flower Pot Saucers- } & \\ 45 & \text { Doz. }\end{array}$

4 -inch .................\$ 25

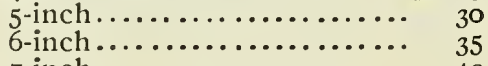

7 -inch ................ 40

Bulb Pans -

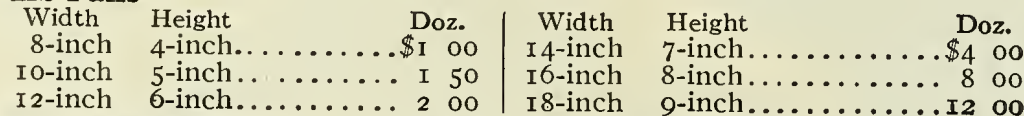

Square Seed Pans-

Doz.

6 -inch..............\$o $75 \$ 425$

7 -inch.............. I $25 \quad 750$

8 -inch.............. I 50 Io oo

9 -inch.............. 2 00 15 0o

1o-inch.............. 27520 co

I2-inch............. 6 oo 4000

9-inch ................\$ 8 Doz 85

10-inch.................. I oo

I 1 -inch.................. I 25

I 2 -inch.................. I 50

I 4 -inch................. I 75

6 -inch $x$ 6-inch $\ldots \ldots \ldots \ldots \ldots . \$ 3$ oo

Io-inch $x$ ro-inch $\ldots \ldots \ldots \ldots \ldots \$$ Doz.

8 -inch $x 8$-inch ..........4 4 oo 12 -inch $x$ 12-inch ..........6 60

Flower Vases (Waterproof) Fiber Ware. Order by number. Inside

111easurements.
Diam. Depth $\quad$ Doz. $\mid$ No. ooo. 9-in. 29 in.......\$33 on

No. o. 8-in. $\quad 13$-in......\$6 6o No. oo. 9 -in. $22-i n . \ldots \ldots \ldots 2500$

No. I. $51 / 2-i n$. Io-in....... 570 No. 1 I. $51 / 2$-in. I 8 -in........ 660

No. 2. $4^{1 / 2}$-in. 9 -ir1....... 5 oo No. 22. $4^{1 / 2}$-in. I 5 -in....... 570

No. 3. 4-in. 6-in......4 420 No. 33. 4 -in. 12 -in....... 5 oo

No. 4. 3-in. $\quad 4 \frac{1}{2}-i n \ldots . . .330$ No. 44. 3-in. 9 -in...... 420

Flower Pot Saucers (Waterproof) Fiber Ware- Each Doz.

\begin{tabular}{|c|c|c|c|c|c|}
\hline & ich & Doz. & $9-$ inch..............\$o & 22 & $\$ 2$ IO \\
\hline & I2 & $\$ 125$ & Io-inch... & 23 & 220 \\
\hline - & I5 & I 50 & I2-inch. & 25 & 250 \\
\hline$\cdots$ & I7 & I 60 & I4-inch & 30 & 350 \\
\hline . & I9 & I 80 & I6-inch.... & 45 & $45^{\circ}$ \\
\hline$\ldots$ & $2 I$ & 200 & I8-inch. & 50 & 500 \\
\hline
\end{tabular}

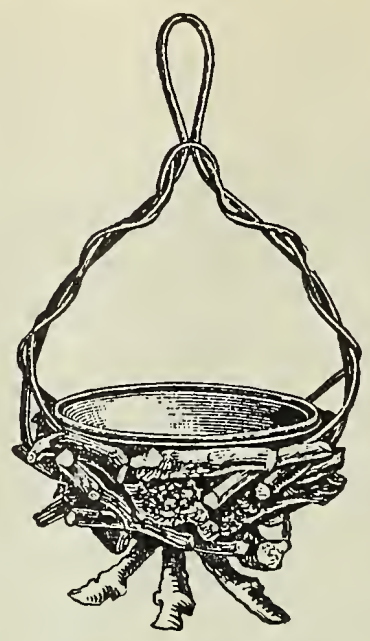

Rustic Hanging Basket

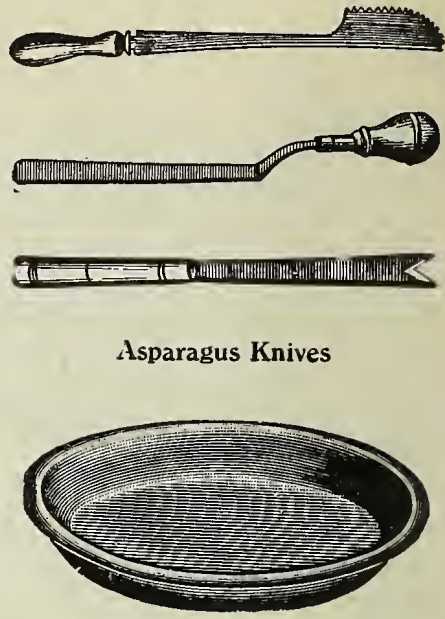

Flower Pot Saucers

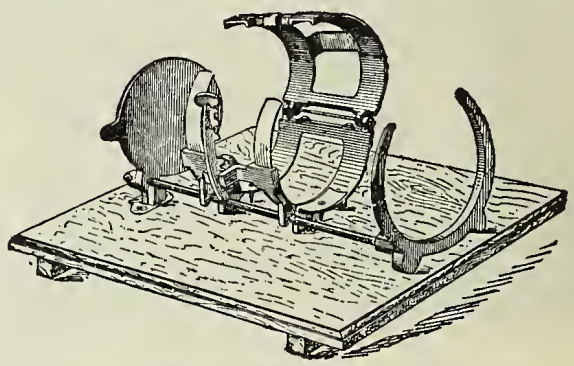

Acme Asparagus Buncher

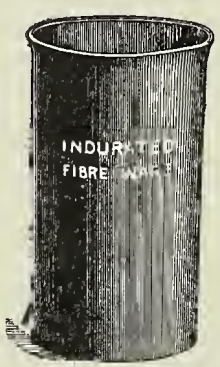

Flower Vase

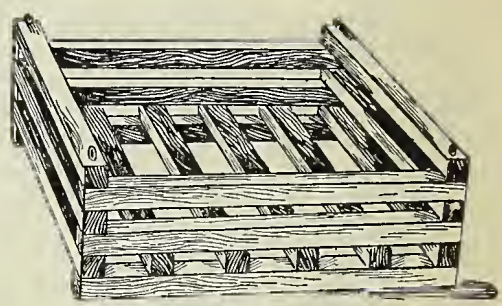

Orchid Box

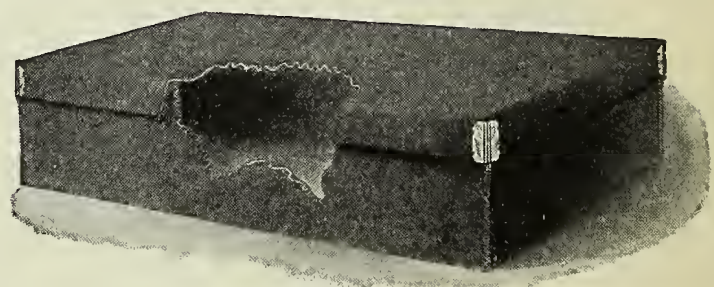

Corrugated Flower Boxes
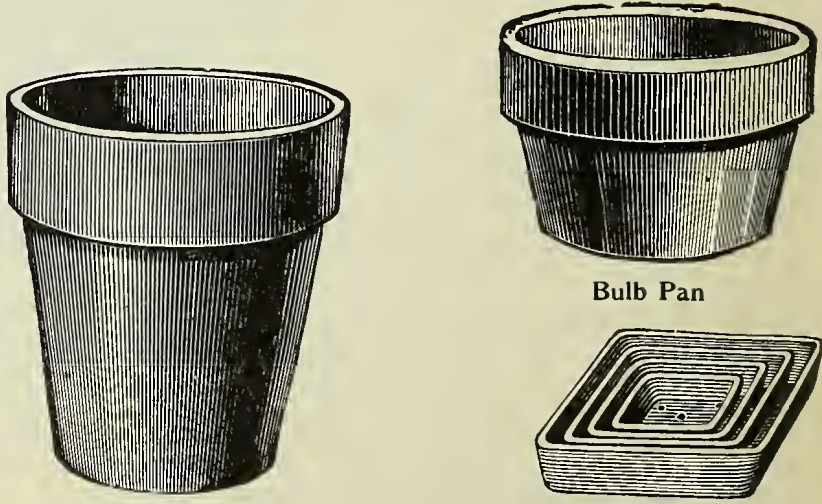

Bulb Pan

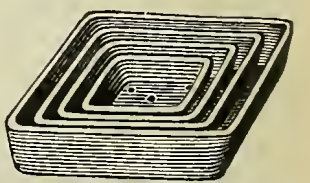

Square Seed Pans 
Rolling Stands for Heavy Plants-

Outside diam. Diam. at

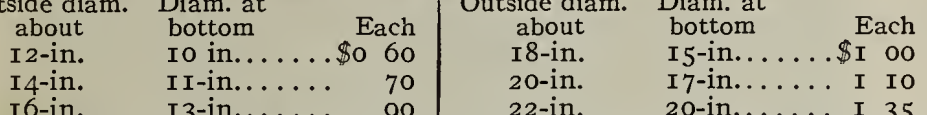

I6-in. I3-in...... 90 22-in. 20-in....... I 35

Flower Pot Brackets. Made of steel, artistic in design, finished in black. Saucers are absolutely secured by spring clasp. Each No. IA. Length of arm 8-in. Clasp will hold 5-in. pot....\$0 30 No. 2A. Length of arm Io-in. Clasp will hold 6-in. pot..... 40 No. 3A. Length of arm I2-in. Clasp will hold 7-in. pot..... 45

Flower Pot Handles and Hangers, Krick's Perfect- Doz.

No. 0 . Will fit from 2 - to $31 / 2$-in. pots.............. \$o 20

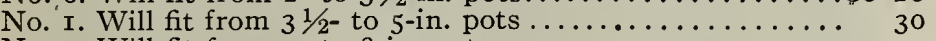

No. 2. Will fit from 5 - to 8 -in. pots................. 40

No. 3. Will fit from 8- to I 2 -in. pots................. 50

Fork, Strawberry. Useful for weeding or general garden use. Io-inch. 25 cts.

Hay. Finest quality steel; oval-shaped tines, solid steel shank, patent ferrule long and strapped. 2 -tine, 50 cts. each, $\$ 5.75$ per doz.; 3-tine, 6oc. each, $\$ 7$ per doz.; 4 -tine, 7 oc. each, $\$ 8$ per doz.

Manure. Long or short handle. 4-tine, D handle, best material. \$I each; 5-tine, D handle, best material, $\$$ I.25 each.

Spading. 4-tine, D handle, best material, \$I each; 5-tine, D handle, best material, $\$$ I.25 each.

Fruit-Picker, Perfect. Galvanized wire, to fit any-sized pole. 35c.

Fumigators and Vaporizers. (See page 125.)

Garden Set, Ladies'. 3 pieces, $\$$ I.

Garden Line. Best braided linen. Ioo ft., 50 cts. Reels, 60 cts.

Gardeners' Gloves. Heavy goat, for protecting hands. \$I per pair.

Glass Cutter, Red Devil. Io cts., I5 cts., 25 cts. and 50 cts.

Diamond. $\$ 3$ and $\$ 4$

Glazing Points, Van Reyper's. 65 cts. per $1,000, \$ 3$ for 5,000 . Model. 40 cts. per $1 \mathrm{~b}$.

Siebert's Never-Rust Glazing Pegs. $50 \mathrm{cts}$. per lb.

Glazing Putty, Twemlow's Old English. Will not crack or peel One gallon glazes 300 lineal feet. Qt. 55 cts., gal. \$1.75.

Grass Hook, Little Giant. Forged steel shank. 50 cts.

Imported English, Riveted Back. Small size, 50 cts.; medium size, 55 cts.; large size, 60 cts.

Grafting Wax. 1/41b. Io cts., 1/21b. I5 cts., 1b. 25 cts., postpaid, 40c.

Hoes, Draw or Garden. Extra-quality, cast-steel, oil-tempered, polished blade. 5 -inch blade, 35 cts. each, $\$ 3.60$ per doz.; 6-, 7and 8-inch blade, 45 cts. each, \$5 per doz.

Acme. Very popular tool for gardeners and florists for drilling, cultivating and weeding. Double prong, $41 / 2$-inch blade. $50 \mathrm{cts}$.

English Scuffle. 5-inch, 50c.; 6-inch, 55c.; 7-inch, 60c.; 8-inch, 65 c. ; 9-inch, 70c.; Io-inch, 75c.; I2-inch, $85 \mathrm{c}$. Handles Ioc. extra.

Weeding. Two-prong. A very useful tool for general garden work. 35 cts. each, $\$ 3.60$ per doz.

Grub. Strong for grubbing out roots, etc. $31 / 2$-1b. 85 cts., $4-1$ b. $\$$ I, $41 / 2$-lb. $\$$ I. 25 , including handle.

Warren. These Hoes are unequaled for hoeing, weeding, cultivating, making drills, covering seed, etc. Small size, 65 cts.; medium, 70 cts.; large, 75 cts.

Hose, Garden or Greenhouse-

Electric. Cut in any length. $20 \mathrm{cts}$. per $\mathrm{ft}$.

Wayahead. Seamless tube Hose- not a complaint from 10,000 feet sold last season. Cut in any length. I 8 cts. per foot.

Wearlong. A very good cheap-price Hose that has given excellent satisfaction. 25 - and $50-\mathrm{ft}$. lengths, I 2 cts. per $\mathrm{ft}$.

All our Hose is guaranteed for the season, and any piece found defective will be replaced immediately

Hose Coupling, Plain Faucet. With this attachment any hose may be connected with the kitchen faucet. $50 \mathrm{cts}$; by mail, $55 \mathrm{c}$

Hose Menders, Cooper's Brass. 1/2- and $3 / 4$-inch, 75 cts. per doz.; I-inch, 85 cts. per doz.

Cauldwell's. Practical, simple and perfect. Box of 6 tubes, 20 bands and pliers, 75 cts.; by mail, $\$ \mathrm{I}$. Give size of hose when ordering. Extra tubes, $3 / 4$-inch, 3 cts. each, 20 cts. per doz.; extra pliers, 30 cts. each.

Jones' Iron. 5 cts. each, 50 cts. per doz.

Hose Nozzles, Graduating Spray. Will throw a fine or coarse spray. 40 cts. each.

Bordeaux Spray Nozzle. Excellent for spraying. $90 \mathrm{cts}$.

Boston. Copper face. 5o cts. each.

Fairy. Brass. 50 cts. each.

Seneca. Gives fan-shaped spray. $\$$ I.25 each.

Boss. Very effective for use on red spider. $\$$ I each.

Shubert. Best made for general all-round use. Solid brass. $\$ 2.50$.

Mistry Jr. Can be used for spraying whitewash. \$I each.

Hydrant Swivel. Turns in any direction, preventing hose from kinking. For $3 / 4$-inch hose, 90 cts.; by mail, $\$$ I.

Hose Cart, No. 1. For lawn or garden; very simple in construction; easily manipulated and almost unbreakable. $\$ 3$.

Hose Reel, K. C. All metal, tubular frame. corrugated drum to allow circulation under hose. \$2.

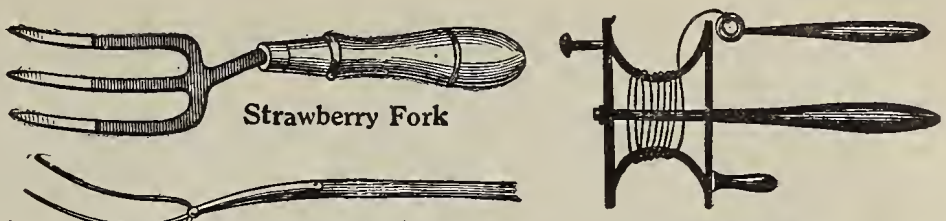

Hay Fork

Garden Reel
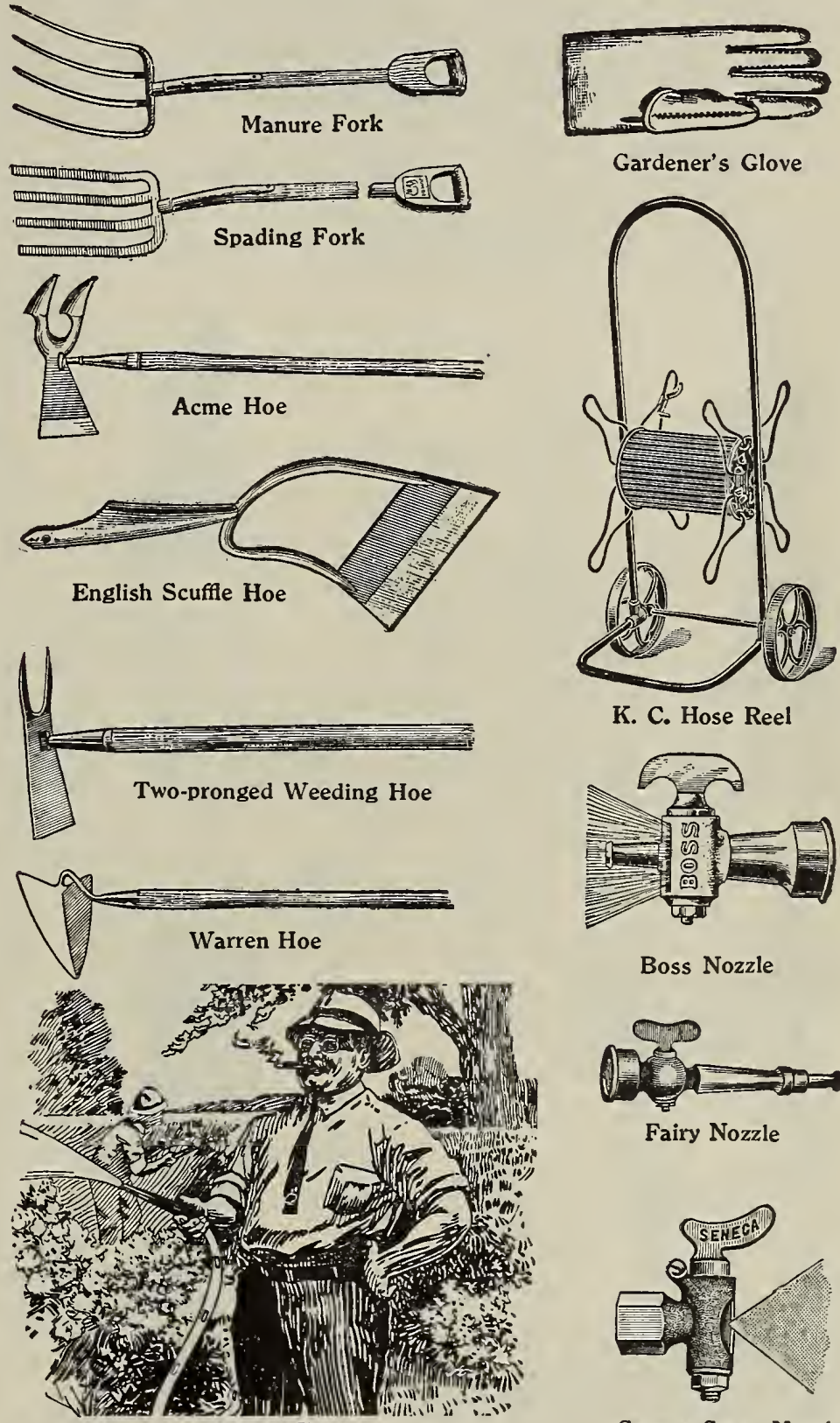

Electric Hose

Gardener's Glove

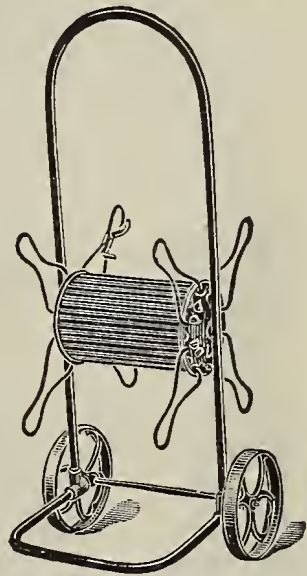

K. C. Hose Reel

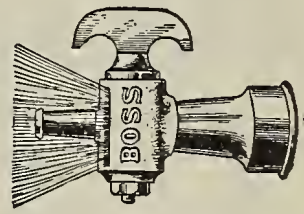

Boss Nozzle

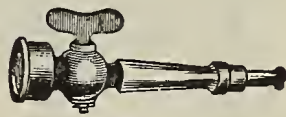

Fairy Nozzle

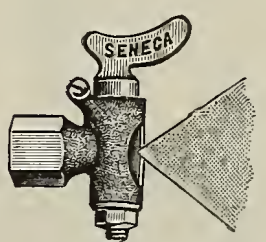

Seneca Spray Nozzle

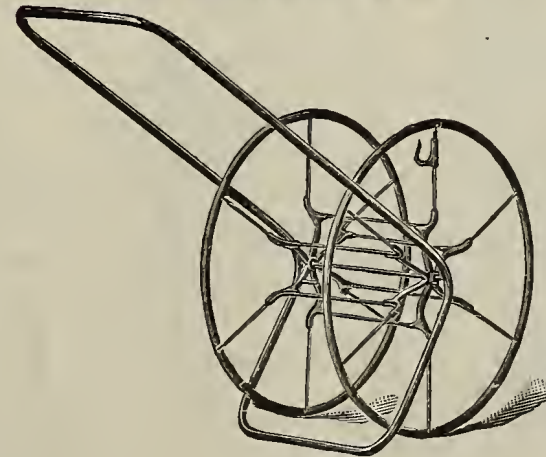

Hose Cart No. 1

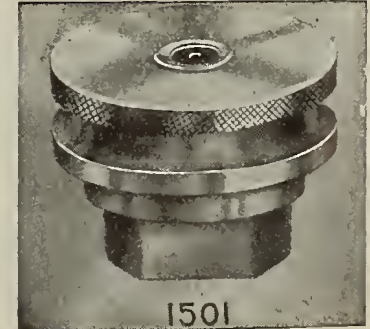

Mistry Jr. Nozzle 
Horse Boots. These boots are made from our own special design, and after two years' practical test, by an expert greenkeeper, have been pronounced by him as being the best-patterned boots made. Price, per set (4 boots), \$9.

Hotbed Mats. Burlap, for protecting coldframes and hotbeds. Warmly lined with waste wool and cotton, which are quilted in to hold position.

Each Doz.

No, I. $40 \times 76$ in. Burlap both sides............... \$I oo \$10 oo

No. I. $76 \times 76$ in. Burlap both sides............... I 40 I5 oo

No. 2. $40 \times 76$ in. Waterproof Duck and Burlap....... I 25 I2 00

N. 2. $46 \times 76$ in. Waterproof Duck and Burlap.....2 2 oo 20 oo

No. 3. $40 \times 76$ in. Waterproof Duck on Both sides.... I 50 I6 oo

No. 3, $76 \times 76$ in. Waterproof Duck on Both sides.... 25025 oo

Hotb ed Sash. Well made from clean cypress, glazed and painted two coats white paint. $\$ 3.50$ each, $\$ 40$ per doz.

Double Glass Sash. Two layers of glass with an air-space of one inch between. $\$ 5$ each, $\$ 55$ per doz.

Knives, Turf Edging. For cutting edges of walks, flower-beds,

Solid Welded Steel Edging. Socket handle; made of the very best steel; imported English. Price, with handle, \$1.50.

Pruning-

No. I, horn handle, I blade......................\$r oo

No. 2, " " I "

No. 3, " " 2 blades......................... I oo

No. 4 , ebony " I blade.......................... 75

No. 5 " " $\quad$ " $\quad \ldots \ldots \ldots \ldots \ldots \ldots \ldots \ldots \ldots \ldots \ldots, 6_{5}$

Budding

No. A, ivory handle, Saynor ....................... I 75

No. B, bone "

No. C, ivory " $\quad$ S. \& W........................... I 50

No. D, "

No,

-.......................... I 25

Labels, Wooden, Pot or Garden-

\begin{tabular}{cc|ccc} 
PLA1N & PAINTED & PLAIN & PAINTED \\
$100 \quad 1,000$ & $100 \quad 1,000$ & 100 & 1,000 & $100 \quad 1,000$
\end{tabular}

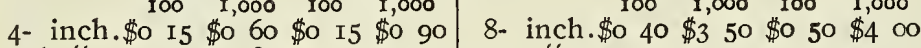

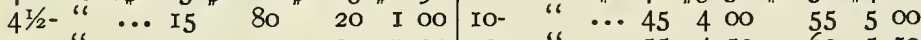
5- “ 6- " $\quad \ldots 20$ I oo 25 I $35 \quad 33 / 4$ " Copper-wired . $25 \quad 2$ o0

Labels, Zinc Garden. These are unsurpassed, being neat, durable and indelible. The ink marks a jet-black, which remains distinct. Use a clean quill or a pointed stick.

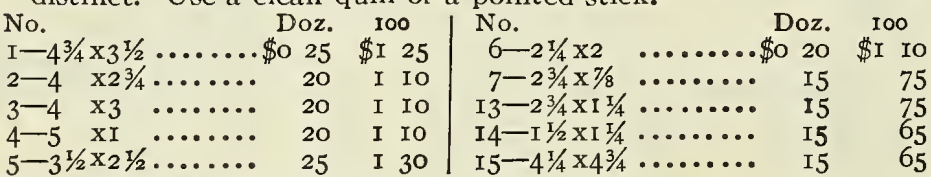

Melon Nets. \$I.5o per doz.

Mole Trap, Olmstead's Improved. \$I.50 each, \$I5 per doz.

New Model. \$I.50 each, \$15 per doz.

Reddick's. \$I each, \$Io per doz.

Out-of-Sight. 75 cts. each, $\$ 8$ per doz.

Paper-

Wax. $24 \times 36$. Ream ....\$3 $\$ 0$ Tissue. $24 \times 36$. Ream.... 2 oo

Paper Pots, Neponsett. Very economical; waterproof; can be nested closely for shipping.

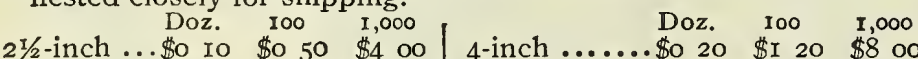

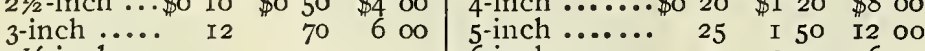
$3 \frac{1}{2}$-inch... I4 $90 \quad 7$ co 6 6-inch ........ 30 2 oo 16 oo

Pencils, Indelible, Wolf's. Io cts. each, \$I per doz'.

Indelible Ink. $25 \mathrm{cts}$. per bottle.

Post-hole Diggers. Lock leather. \$1.75 each.

Augers. \$2 each.

Prumers, Waters' Tree. Best pruner on market. $4 \mathrm{ft}$., 75 cts. $6 \mathrm{ft}$., $85 \mathrm{cts}$.; $8 \mathrm{ft}$., \$I; Io ft., \$I.I5; I2 ft., \$1.25.

Putty Bulb. For distributing Twemlow's Putty, etc. \$I.

Raffia, Natural. For tying. $25 \mathrm{cts}$. per lb. \$I. Io for $5 \mathrm{lbs}$.

Rakes, Wood Hay Rake. I 2 -teeth. $30 \mathrm{cts}$. each, $\$ 3$ per doz.

Wood Lawn Rakes. 24-teeth. 35 cts. each, \$3.50 per doz.

Gravel, Short Teeth. I 2-teeth 40c., I4- 50c., I6- 60c., I8-700

Steel Garden. Bow handle. I I-teeth 70c., I3- 75c., I5-8oc.

Steel Garden. I0-teeth 50c., I2- 55c., I4-60c., I6- $65 \mathrm{c}$.

Saws, Pruning, Plain One Edge. I 2 -in. 40 cts., I 4 -in. 50 cts., I6-in. $60 \mathrm{cts}$, I 8 -in. $70 \mathrm{cts}, 20$-in, $80 \mathrm{cts}$., 22 -in, $90 \mathrm{cts}$

Pruning, Double Edge. I 2 -in. 40 cts., I 4 -in. 50 cts., I6-in. 60 cts., I 8-in. 70 cts., 20-in. 80 cts., 22 -in. 90 cts.

Little Giant Pruning Hook and Saw, Combined. Can be attached to pole any length. \$I.50.

Scythes. Imported English, riveted back, also solid back. 32-in. \$I.40, 34-in. \$I.50, 36-in. \$I.6o, 38-in. \$I.70.

Little Giant. Solid steel, 28-in. \$I.I 5, 30-in. \$1.25, 32-in. \$1.35, 34-in. \$I.40.
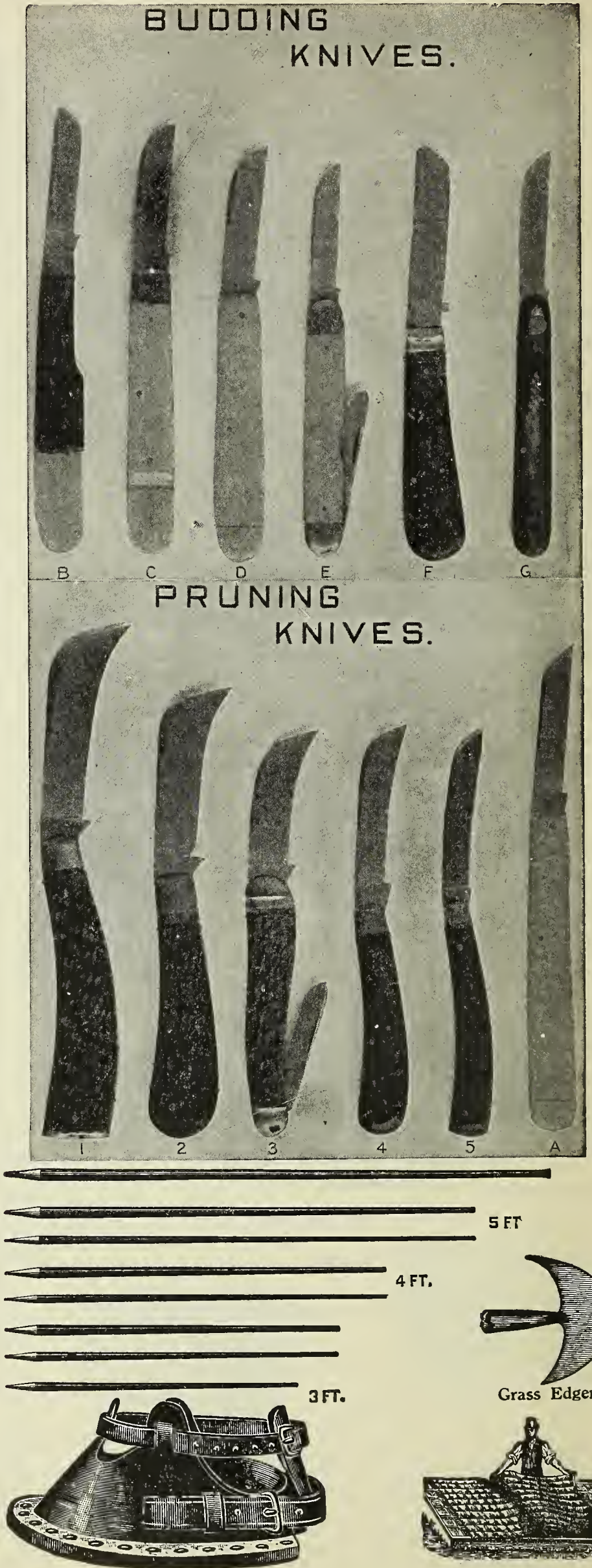

Horse Boot

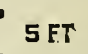

$4 \mathrm{FT}$.
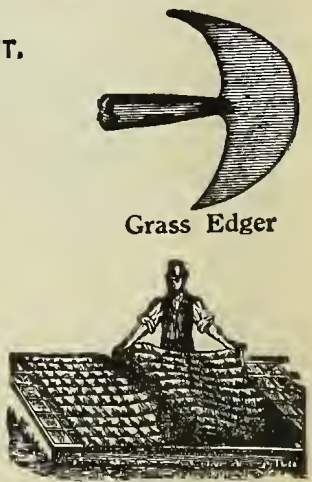

Hotbed Mat 
Scythes, Snath and Handle. Patented; best quality. $90 \mathrm{cts}$. Stones. English Talacre Quarry. $25 \mathrm{cts}$. each, \$2.50 per doz.

Rifles. Emery coated. I5 cts. each, \$I.50 per doz.

Scissors, Grape-thinning, English. Best steel. $75 \mathrm{cts}$.

American Flower-gathering. $75 \mathrm{cts}$.

Shears, Pruning. Kunde Shears are the best and strongest solid steel shears made. $\$ 3$.

French. $51 / 2$-in. $\$ 1.25,61 / 2$-in. $\$$ I. 35,8 -in. $\$$ I.45, 9-in. \$I.75.

Wiss. Solid steel. 9-in. \$2, I0-in. \$2.50.

S. \& W. Co.'s Special. Steel blades, malleable handles. 50 cts.

Ladies' Nickel-plated. $5 \frac{1}{2}$-in. 90 cts., $61 / 2$-in. \$I.

Branch, or Lopping. Three sizes, $\$ 2.50, \$ 2.75$ and $\$ 3$.

Grass. Full nickel, solid steel. 6-in. blade 75 cts., 7 -in. blade $\$$ I.

Grass, Imported English. Best procurable. $61 / 2$-in., bent, \$1.25.

Border and Grass-edging. Io-in. blades $\$ 2.50$; with wheel $\$ 2.75$.

Lawn. Io-in. blades, with two wheels, $\$ 2.75$.

Hedge. Imported English, plain blade. 8-in. \$1.25, 9-in. \$1.50, Io-in. \$2; 8-in. notched, \$1.50, 9-in. notched, \$1.75, I0-in. notched, \$2.25.

Silkaline. Largely used for tying in bouquet work. Fine, medium and coarse. Per spool 25 cts., \$1.50 per box of 8 spools.

Shovels, Ames' Long and D Handles. Long-strapped, round or sq. \$I.50. Sickels' Pointed and Square. \$I.

Spades, Ames' Long and D-Handles. \$1.50.

Thermometers. While we exercise great care in packing, Thermometers travel at purchaser's risk only.

Copper Case. Spirit; easy reading. 8 -in. 50 cts.

Japan Case. Scale bronze-brass, mercury. 8-in. 75 cts., Io-in. \$I.

Self-registering, Tin Case. $\$ 2.50$.

Mushroom and Hotbed. Heavy brass point, \$1.50; all copper, point may be removed and cleaned, $\$ 2$.

Stakes, Plant, Tapering, Green-

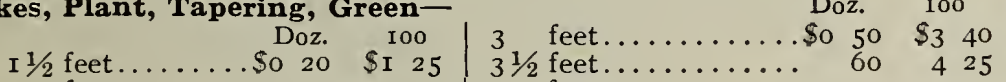

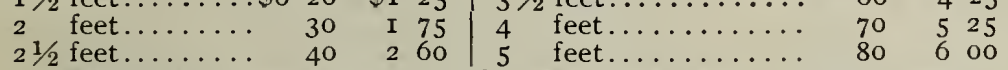

Chinese Cane. These are genuine Chinese canes, very strong and heavy.

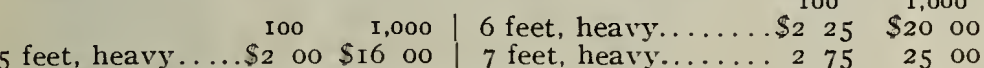

Japanese Cane. For staking plants and trees.

\begin{tabular}{|c|c|c|c|}
\hline & 1,000 & 100 & $\mathrm{I}, \mathrm{O}$ \\
\hline . $\$$ I 00 & $\$ 8$ oo & I 4 feet. & $\$ 65$ \\
\hline I 50 & I 200 & I6 feet & 90 \\
\hline 300 & 2500 & I 8 feet & IIO \\
\hline 500 & 4500 & 2 feet & I 40 \\
\hline a Pol & 100 & $\begin{array}{l}\text { Doz. } \\
\text { SI oo }\end{array}$ & $\begin{array}{l}\text { Io } \\
\$ 8\end{array}$ \\
\hline \$o 75 & $\$ 600$ & I 30 & IO \\
\hline $1 / 2$ feet & 700 & 6 feet & I I \\
\hline Ivanized Wire & $\mathrm{I}, 000$ & 100 & \\
\hline 175 & \$1 250 & 250 & $\begin{array}{r}\$ 18 \\
20\end{array}$ \\
\hline $\begin{array}{r}1 / 2 \text { feet........ } \\
\text { feet....... }\end{array}$ & $\begin{array}{l}\text { I } 450 \\
\text { I6 } 00\end{array}$ & $\begin{array}{ll}5 & \text { feet } \ldots \ldots \\
6 & \text { feet....... }\end{array}$ & $\begin{array}{l}20 \\
25\end{array}$ \\
\hline
\end{tabular}

Tomato Supports, Wire. 32 inches high, 14 inches in diameter, made of heavy steel wire. I 5 cts. each, \$I.50 per doz., \$I 2 per Ioo.

Perfection Patent Wood. 36 inches high, and I 2 inches wide. Can be taken apart and stored. $25 \mathrm{cts}$. each, \$2.50 per doz.

Plant Tubs, New York Cedar. Made of the very choicest seasoned cedar highly finished with black hoops; will last twice as long as cypress tubs.

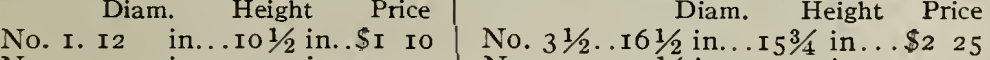

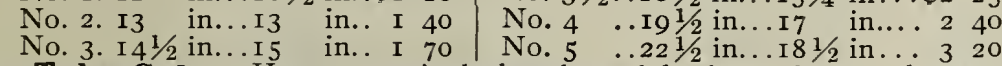

Tree Tubs, Cedar. Heavy; particularly adapted for large, heavy plants.

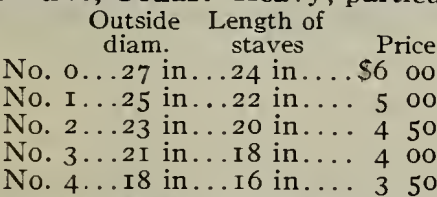
Outside Length of diam. staves

Price No. $5 \ldots .16$ in .......14 in...\$3 00 No. $6 \ldots . .14$ in....... 2 in .... 250 No. $7 \ldots . .13$ in ........ I in .... 225 No. $8 \ldots 12$ in......... in in ... 2 oo

Torch, Asbestos. 35 cts. each; by mail, 45 cts.

Watering Pot, Haw's Pattern. No. 0, 3-qt., shelf, 9-inch spout, one pot rose and extra joint, \$2. No. 2, 4-qt., japanned, 2 roses, \$3. No. 3. 6 -qt., japanned, 2 roses, $\$ 3.50$. No. 4, 8-qt., japanned, 2 roses, $\$ 4$. No. 5, Io-qt., japanned, one rose and spreader, $\$ 4.50$.

Watering Pot. Heavy galvanized, round and oval; each can has two roses - one fine and one coarse.

6 -quart, round..........\$2 oo

8 -quart, round............ 225

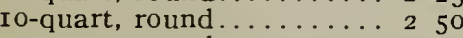

6-quart, oval..........\$2 25

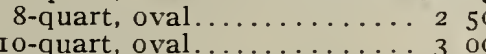

3 oo

Weeders, Hazeltine. $20 \mathrm{cts}$. each, $\$ 2.25$ per doz.; postage $5 \mathrm{cts}$ extra.

Excelsior Finger. Claw fingers. Ioc. each, SI per doz.; postage 5c. ex.

Eureka Hand. Short handle. 25c. ea., \$2.75 per doz.; postage IOc. extra.

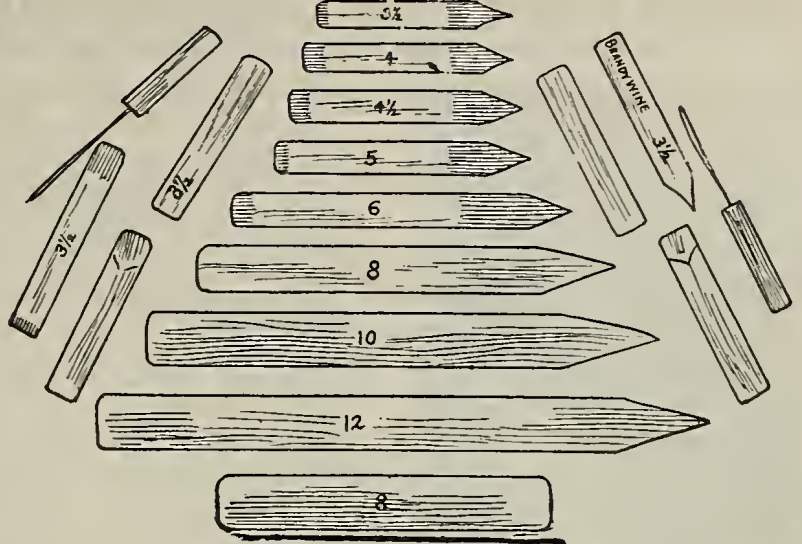

Labels, Wooden, Pot and Garden
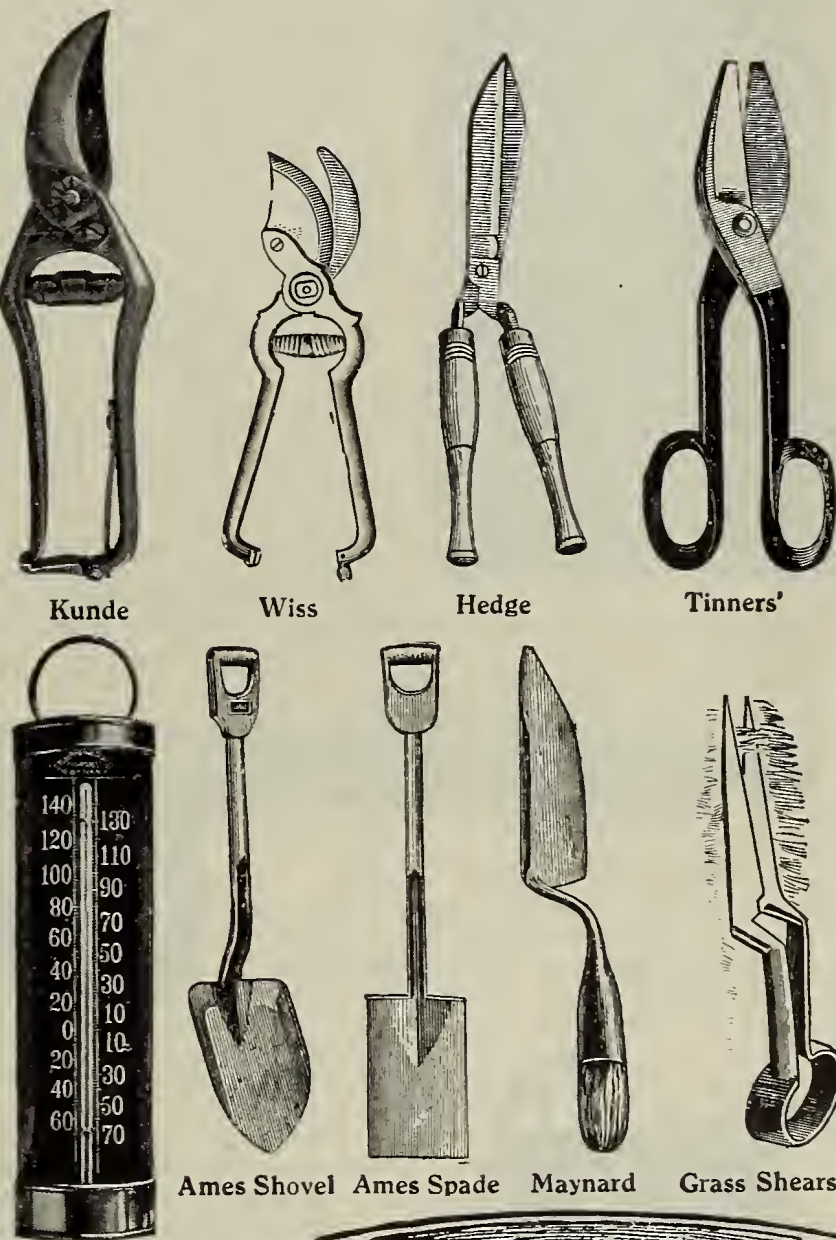

Wiss

Hedge

Tinners'
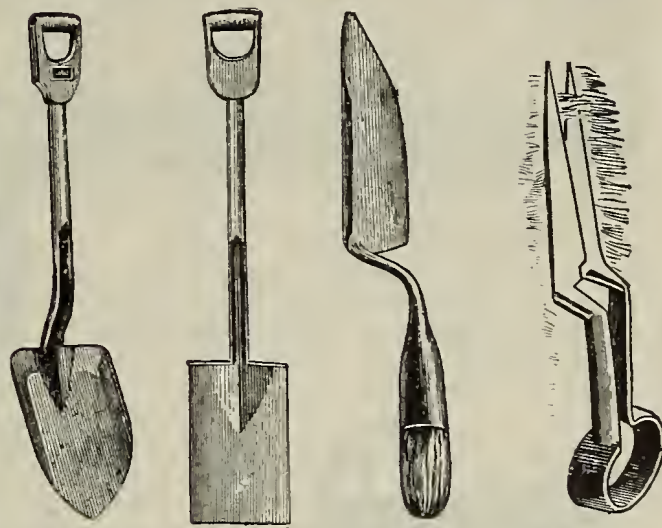

Ames Shovel Ames Spade Maynard Grass Shears

Thermometer

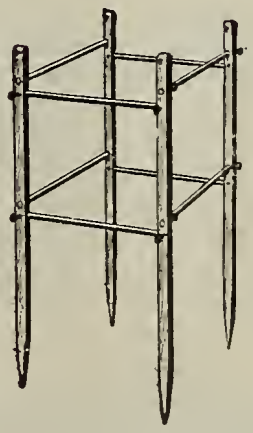

Perfection Tomato Support

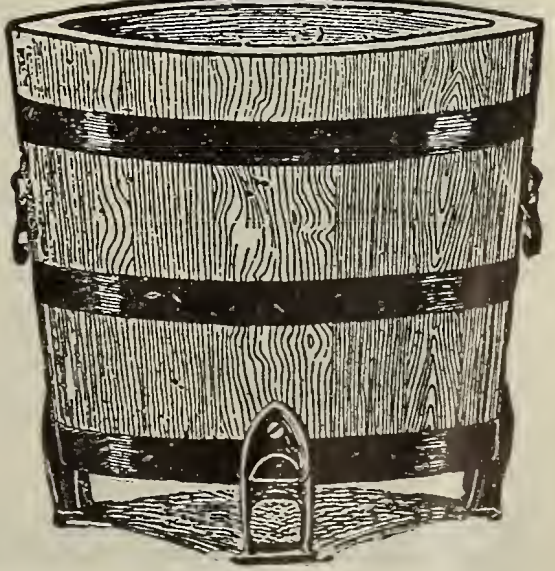

New York Cedar Tub 


\section{Sprayers for Applying Insecticides and Fungicides}

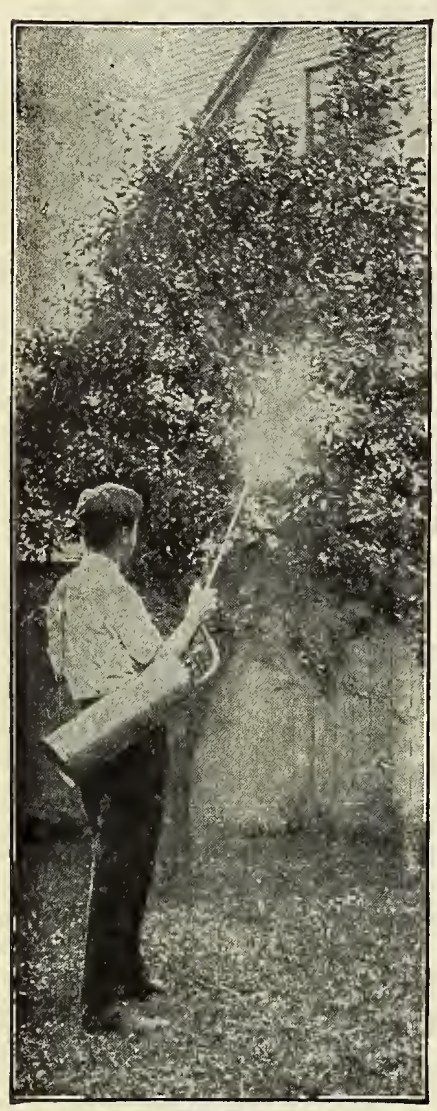

\section{AUTO-SPRAY}

Convenient, durable, efficient. Our patented leader of spray apparatus for small uses. Will do better work and do it easier than any other similar article. Useful with Bordeaux and all solutions, also in applying cold water paints or whitewash. Holds four gallons. Illustration shows our new "Auto-Pop" attachment which doubles the efficiency by saving half the solution and labor. Our "Anti-Choke" Nozzle, cleaned at every operation of "AutoPop," can never clog. Tank made of galvanized steel or brass. Highgrade hose. Heavy self-contained pump, all brass. Nipple connections, nozzle, etc., turned from solid brass rod with full threads. Castings for handle, etc., all malleable. No continuous pumping as in the cases of the Knapsack Sprayer, no continuous pumping or slopping as in the case of the bucket pump. A few strokes of plunger compresses enough air to cover a quarter acre of potatoes or similar crop. The operator simply holds the nozzle. Also used for spraying disinfectants. A practical machine for potatoes, tobacco, small fruits, vineyards, poultry-houses, greenhouses, etc. Extension pipes useful for spraying tall trees. Detailed descriptive circular on request.

"Auto-Spray," No. I, Brass

Tank, with Stop Cock ....\$ \$675 "Auto-Spray," No. I, Brass

Tank, with "Auto-Pop," ...775 "Auto-Spray," No. I, Galvanized Tank, with Stop Cock...... 450 "Auto-Spray," No. I, Galvanized Tank, with "Auto-Pop"..... 55 50 "Auto-Pop," supplied separately $\ldots . . . \ldots \ldots \ldots \ldots \ldots \ldots \ldots \ldots \ldots$ I 50

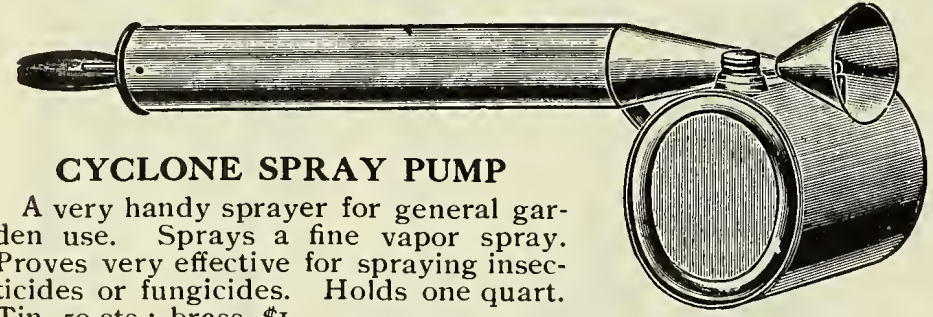
Tin, 50 cts.; brass, $\$ \mathrm{I}$.

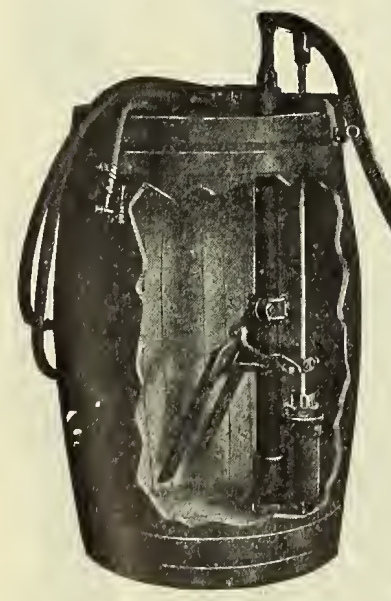

S. \& W. CO.'S "FRUITALL" SPRAY PUMP

The "Fruitall" illustrated herewith has been designed especially to meet the demand for a low-priced sprayer combining the necessary durability, efficiency and strength.

Outfit C. Sprayer with agitator and one lead $1_{5}$ feet $1 / 2$-inch discharge hose, with "Mistry" or "Mistry Jr." spray nozzle. Price, without barrel, \$1 3.50.

Outfit D. Sprayer with agitator and two leads, I 5 feet each, $1 / 2$-inch discharge hose, with "Mistry" or "Mistry Jr." spray' nozzle. Price, without barrel, \$I6.

If Agitator is not wanted, deduct 75 cents from the list. We supply barrel and mount sprayer on same, for $\$ 3.50$ extra list; but the barrel is not furnished unless specially ordered.

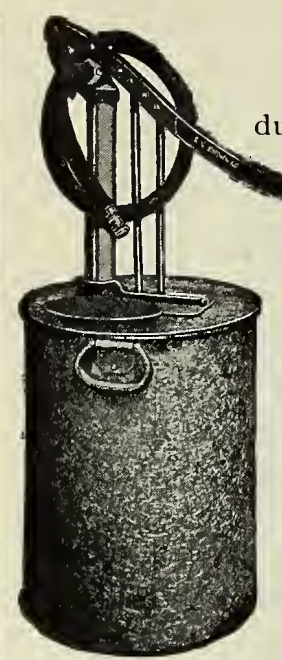

\section{AUTO-SPRAY, WHITEWASH AND PAINT MACHINE}

This is warranted the most powerful and most durable machine in its class.

Tank.-Extra heavy galvanized steel: holds 8 gallons, and has reinforced cover.

Pump.-All brass but handle-fittings; cylinders extra heavy, $1 \frac{1}{2}$ inches in diameter, both air and pump; ball valves and hree-ply hose.

Weight. - Net 20 pounds, shipping 35 pounds. Uses. - Suitable for spraying insecticides and fungicides on trees, shrubs and vines, as well as the application of whitewash or cold-water paints, and will do the work of five men with brushes.

Price, complete with 8 feet of hose, 8 -ft. iron extension and one Vermorel nozzle suitable to all classes of spraying. $\$ 12$.

\section{COMPRESSED-AIR SPRAYER}

An excellent hand compressed-air Sprayer. Tin Tank, 85 cts.; Brass Tank, \$1.50.

\section{S. \& W. CO.'S BUCKET SPRAY PUMP}

Bordeaux Brass Garden and Spray Pump is especially designed for spraying in gardens and greenhouses. Has adjustable foot-piece to fit different size buckets, with $3 \mathrm{ft}$. $3 / 8$-in. hose and spray nozzle. $\$ 3.75$.

\section{S. \& W. CO.'S TRUCK, LEAF-RACK AND WATER- BARREL COMBINATION}

When we consider the almost innumerable uses to which our combined truck, leaf-rack and water-barrel can be put, its handiness and the immense amount of time and hard labor saved by its use, it is not a matter of surprise that it is steadily growing into popular favor. It is one cause the user to wonder how he ever did without it, as it really becomes indispensable when once used. Price, truck and barrel, as in cut, with $21 / 2$-in. tire wheels, $\$ 1$ I

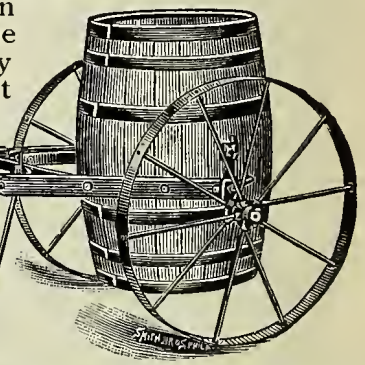

with handy cart box, length $37 \times 23^{1 / 2}$ in. wide by 8 in. deep, $\$ 3$ extra; with leaf-rack, 42 in. long by 28 in. wide by 21 in. deep, $\$ 5$ extra. Price, complete with truck, water-barrel, box and leaf-rack. \$19.

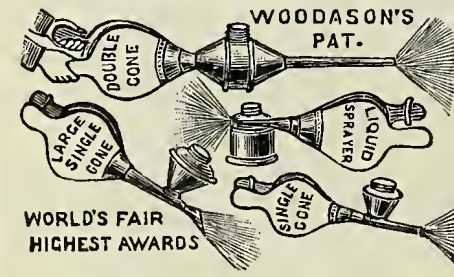

BELLOWS, WOODASON'S Powder, small size ........\$1 25 large size.......... 225 Liquid, small size ............ I 50 large size .......... 225

Double Cone Powder Bellows. For dusting plants with dry powders for insects and fungus. $\$ 3.25$.

\section{SYRINGES}

No. Io. Barrel I8 in. long, one coarse and one fine spray

rose and one stream jet with patent valve and elbow joint. $\$ 6$.

No. II. Similar to No. Io, without patent valve. $\$ 4.75$.

No. G. Barrel 16 in. long; diameter $1 \frac{1 / 2}{\mathrm{in}}$., open rose, one spray rose and jet; one side attachment with angle joint. $\$ 4.50$.

No. 2. Barrel $13^{1 / 2}$ in. long; one coarse and one fine spray and one stream rose; solid brass. $\$ 4.50$.

No. A. Barrel 12 in. long; one spray and one stream rose. \$2.50.

No. H. Barrel 16 in. long, $I^{1 / 2}$ in. diameter with fixed spray rose. Sheet brass. $\$ 2.75$.

Abol Syringe. An excellent brass hand syringe with angle neck attachment. No. 6 , price $\$ 7.50$.

\section{FERGUSON'S COMB'N SPRAYER AND SYRINGE}

Three roses-fine, medium and coarse. Recommended as regards syringing under the foliage of plants where force is needed to keep down red spider, etc. Substantially made of brass and can be screwed on the end of any hose same as an ordinary nozzle. \$3. 


\section{REMEDIES FOR INSECTS AND FUNGUS}

All remedies listed below by the pound, which are non-poisonous, can be sent by mail, if 15 cents is added to cover postage, all remedies otherwise listed are not mailable, unless specially noted.

\section{TO-BAK-INE PRODUCTS}

Will positively kill green and black fly, mealy bug, red spider and other insects on flowers, plants, trees, etc.

TO-BAK-INE FUMIGATING PAPER. Much like Aphis Punk; very high in Nicotine content, and used by leading carnation growers for iumigation; found to be very effective. Box of 24 sheets $75 \mathrm{cts}$., box of I 44 sheets $\$ 3.50$, box of 288 sheets $\$ 6.50$.

TO-BAK-INE LIQUID. Used by leading carnation-growers for fumigating and spraying; high in Nicotine content. $1 / 4 \mathrm{pt}$. \$I.00, $1 / 2$ pt. $\$ 1.75$, pt. $\$ 3.00$.

Aphine. Effective against all soft-bodied and plant-sucking insects, such as green, black and white fly, red spider, thrips, mealy bug, brown and white scale. Used as a spray when diluted in water in the proportions as directed on each can. Endorsed by professional gardeners and commercial growers of reputation. An insecticide which can be used indoors and in the garden. An excellent cleanser for house plants. Gal. $\$ 2.50$, qt. $\$ 1$, pt. 65 cts., $1 / 2 \mathrm{pt}$. $40 \mathrm{cts}$., $1 / 4 \mathrm{pt}$. $25 \mathrm{cts}$.

By special arrangements with the manufacturers, we can send the following sizes express prepaid: Qts. $\$ 1.25$, pts. 75 cts., $1 / 2 \mathrm{pts}$. 50 cts.

Aphis Punk. Used for fumigating in greenhouses, giving off dense fumes of nicotine. Box, I 2 rolls, by mail, 75 cts.

Arsenate of Lead. For all leaf-eating insects. Guaranteed not to injure the foliage. Three pounds will do the work of four pounds of other brands, and will not readily wash off. Guaranteed to contain an average of 20 per cent arsenic. Lb. 25 cts., 2 lbs. 40 cts., 5 lbs. 90 cts., $121 / 2$ lbs. $\$ 2.10,25$ lbs. $\$ 4.10,50$ lbs. $\$ 8$.

Copper Solution. Excellent spray for carnation rust. Good for leaf-blight or mildew. Dilute in water. Qt. \$I.

Fir Tree Oil. The best insecticide in the market for greenhouse and house plants; it frees plants of nearly all insects to which they are subject. 1/2-pt. tin $40 \mathrm{cts}$., pt. $75 \mathrm{cts}$., qt. $\$ 1.25,1 / 2 \mathrm{gal}$. $\$ 2.25$, gal. \$4. Directions for use on each can.

Fir Tree Oil Soap. A formula of the above Fir Tree Oil, prepared in soap form and preferred by some. It will do all claimed for the fluid preparation. $1 / 2-1$ b. tins 25 cts., 2 lbs. $75 \mathrm{cts}$., 5 lbs. $\$$ I.80, Io lbs. $\$ 3.50$.

Fungine. An infallible remedy for mildew, rust, wilt, bench-rot and other blights affecting flowers, fruit and vegetables. Highly endorsed by leading growers. It is equally effective under glass and out-of-doors. A spraying material which is diluted with water and does not stain the foliage. Gal. $\$ 2$, qt. $75 \mathrm{cts.,}$ pt. 50 cts., $1 / 2$ pt. 35 cts.

By special arrangements with the manufacturers, we can send the following sizes express prepaid: Qts. \$I.I5, pts. $75 \mathrm{cts} .1 / 2 \mathrm{pts}$. $50 \mathrm{cts}$.

Grape Dust. For mold, mildew, or rust-mites, either in the greenhouses or open air. 5 lbs. $40 \mathrm{cts}$., $10 \mathrm{lbs}$. $70 \mathrm{cts}, 25 \mathrm{lbs}$. \$1.50.

Kerosene Emulsion. Diluted in water, this makes an excellent spray for mild forms of scale and soft lice of any kind, such as infest rose and fruit bushes, vegetables and trees. Liquid diluted one part to twenty parts of water. Liquid. Qt. $50 \mathrm{cts} .$, gal. \$1.25, 5 gals. $\$ 5.50$.

Lemon Oil. Odorless and poisonless; one to thirty to fifty parts of water. Destroys mealy bug, scale, thrips, red spider, black and green fly, caterpillar, etc. $1 / 2$ pt. 25 cts., pt. 40 cts., qt. 75 cts., $1 / 2 \mathrm{gal}$. \$1.25, gal. \$2.

Nico-Fume (Liquid). Used for same purposes as To-bak-ine. $1 / 4$ pt. 50 cts., pt. \$1.50, 1/2gal. \$5.50, gal. \$10.50.
Nico-Fume. This is a paper similar to Aphis Purk or To-bak-ine, and has proven an effective fumigant. Box of 24 sheets 75 cts., box of 144 sheets $\$ 3.50$, box of 288 sheets $\$ 6.50$.

Nikoteen. One of the milder forms of Tobacco or Nicotine preparations, used extensively for spraying. Pt. \$I.50, I0 pts. \$I 4

Scalecide. Has proven to be one of the most effective remedies for the destruction of San José scale. Everyone should spray in late fall and early spring all trees with this material. One part of Scalecide to twenty parts of water for general use. Qt. can. $40 \mathrm{cts}$., gal. \$I, 5 gals. \$3.25, Io gals. \$6, 30-gal. jacketed tin $\$ 15,50$-gal. barrel $\$ 25$.

Sulphur. Used principally in greenhouses for checking mildew (see below for Campbell's Sulphur Vaporizers), Lb. I0 cts., 5 lbs. $40 \mathrm{cts}$., $10 \mathrm{lbs}$. $60 \mathrm{cts}$., $100 \mathrm{lbs}$. $\$ 5$.

Sulpho-Tobacco Soap. For plants, trees, cattle, poultry, etc. 3-oz. pkg. Io cts., 8-oz. pkg. 20 cts.

Tobacco Dust (Kilmdead). The best of the Tobacco Dusts for dusting or fumigating. Lb. I0 cts., 5 lbs. 40 cts., 25 lbs. \$1.25, 50 lbs. $\$ 2.25$, IOo lbs. \$4.

Tobacco Stems. Used for fumigating and under benches in greenhouses. Bale of Ioo lbs. $\$ 1.50$.

Whale, or Fish Oil Soap. Excellent summer spray for mild forms of scale, insects, etc. Lb. 20 cts., 5 lbs. 75 cts., Io lbs. $\$ 1.25$.

Worm Eradicator. The worm will immediately rise to the surface of the ground of flower bed, or will fall off the trees, fruits or flowers, and in a few minutes will die. 25 -cent bottle makes 5 gallons; 50-cent bottle makes Io gallons; \$I bottle makes 25 gallons.

X-L-ALL LIQUID INSECTICIDE. Destroys mealy bug, scale. thrip, red spider, green and black fly, caterpillars, blight and all insect pests in the garden; it is perfectly safe to use on tender plants. For the winter dressing of vines, figs, peaches and other fruit trees, it has been proven to be the safest and most valuable preparation in the market. Leaves the foliage bright and clean, and much improved in appearance. Qt. \$I, 1/2gal. \$I.75, gal. \$3.50.

\section{Fumigators and Vaporizers}

Fumigator, "Eureka." For fumigating with tobacco stems. Each No. I holds $1 / 2$ peck stems $\ldots \ldots \ldots \ldots \ldots \ldots \ldots \ldots \ldots \ldots$ \$I 50 No. 2 holds I peck stems.

No. 3 holds $1 / 2$ bushel stems.

, Camplell's Patent mildew and other fungous diseases. Each No. I. For houses up to 5,000 cubic feet of space.......\$6 oo No. 2. For houses up to 10,000 cubic feet of space....... 750 Glass Balls for above. Per box of 6, $15 \mathrm{cts}$.

Yellow Powder. Per tin, 20 cts.

Hollow or Solid Wicks, for either size, I5 cts.

\section{COCOANUT FIBER, PEAT, MOSS}

Cocoanut Fiber. Excellent material for use in growing bulbs. 4 qts. 25 cts., pk. 40 cts., bus. \$I, 5 bus. $\$ 3$.

Rotted Fibrous Peat. An excellent material for mixing with potting soil for many plants. This peat has been dug from an old bog, and exposed for a number of years until it has become thoroughly decayed. Per bb1. \$2.50.
Orchid Peat. Per bbl. $\$ 2.50$.

Sphagnum Moss. We can furnish this in best quality; either freshly gathered ( $g_{1}$ een) or dried. $\$ 2.50$ per bale, green, or $\$ 3$ per large bale, dried.

Charcoal. See cover page.

NOTE on Fumigating with Hydrocyanic Acid Gas-Cyanide Potassium (Poison) as given to us by a practical gardener. Put a tablespoonful of water in a galvanized iron pail, add to this I oz. of sulphuric acid, wrap an ounce of Cyanide of Potassium in pape and place it in the bucket which should be placed near the door of the greenhouse to afford quick exit; the moment the Cyanide strikes the liquid it generates a poisonous gas which must not be inhaled. The above charge is sufficient for a house $20 x 100 \mathrm{ft}$. Don't open the greenhouse for at least I2 hours. One of the ventilating sash should be arranged so it can be opened from the outside to allow the fumes to escape entirely before entering. This is claimed to be the only and best remedy to absolutely kill the white fly. It is claimed that it will not injure the most delicate plant but the user should take great care of himself. We can supply all the ingredients for making this. 


\section{INDEX}

\section{Bulbs}

Achimenes

Aconite, Winter

Agapanthus.

Alliums.

Alstrœmeria

Amaryllis.

Anemones.

Anomatheca.

Babiana

Bleeding Heart:

Calla.

Camassia

Chionodoxa.

Colchicum . .

Crocus.

Crown Imperials

Cyclamen .

Daffodils

Dielytra.

Eranthis.

Eremurus

Erythronium

Freesia.

Freesia, Scarlet

Fritillaria

Gladioli, Winter-flowering

Glory-of-the-Snow

Gloxinias. .

Hyacinths.

Bedding

Double Named

Dutch Roman or Miniature. I

Feathered.

Forcing

Grape.

Named Exhibition

New and Choice.

Select Unnamed

Iris.

Ixias

Jonquils....

Leucojum .

Lilies.

Lily, African

American Wood

Annunciation

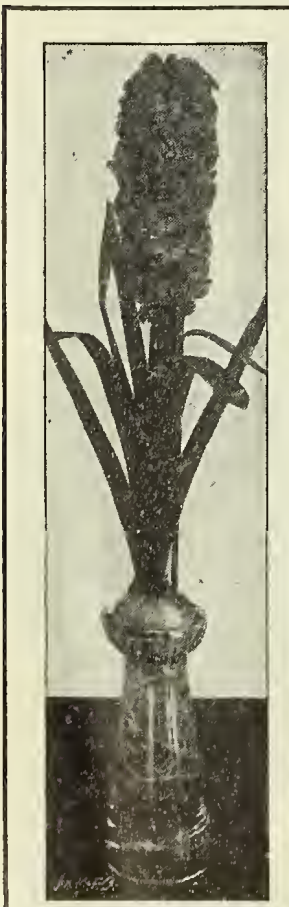

Tye Shape
Lily, Barbadoes. P $A$ GE

Bermuda Easter

Coral.

Jacobran

Madonna.

Golden-rayed, of Japan

Peruvian.

St. Joseph's.

Tiger.

True Guernsey

Lily-of-the-Valley .

Narcissi.

Double.

Giant Trumpet

Jonquilla.

Medium Trumpet

Poetaz.

Poet's.

Polyanthus.

Van Sion.

Nerines.

Ornithogalum

Oxalis.

Peonies

Quamash, Indian.

Ranunculus.

Richardia.

Scillas

Snowdrops

Snowflake, Spring

Sparaxis.

Spiræa

Star of Bethlehem

Sternbergia.

Trillium.

Tritonia.....

Tuberoses. . . . . . . . . . . . . . . . . . . . . . . .

$\cdots 34$

Botanical.

Cottage

Double Early.

Dutch Breeder.

New Giant Darwin.

Parrot.

Rembrandt

Single Early . . . . .
Violet, Dog's-tooth.

I 7-22

I8, I9 \begin{tabular}{l|l} 
PAGE & Esculent Roots
\end{tabular}

Asparagus Roots ........... PAGE

Rhubarb Roots............. . . . . . . .

Kale, Sea.............. . 4 I

\section{Farm Seeds}

Alfalfa.

Clovers

Rye, Winter .

Timothy

Vetch, Winter

Wheat, Winter

$\ldots \ldots \ldots . \ldots 49$

\section{Flowering Plants}

Begonia................40

Cineraria

Cyclamen.

Primula.

Violets.

Flower Seeds for

\section{Autumn Sowing}

Antirrhinum............ 36

Asparagus................

Bellis.................... 36

Butterfly Flower. . . . . . . . .38

Calceolaria.

Calendula. .

Calliopsis

Candytuft

Centaurea.

Cineraria.

Cornflower

Cyclamen

Daisy, Double

Forget-me-not

Fringe Flower

Iberis

Marigold, Pot

Mignonette

Myosotis. . .

Pansies...
Priminge.............

Primula. .

Schizanthus.

Snapdragon................36

Stocks, Winter-flowering. . . . . . 39

Sweet Sultan, Giant..........37

Sweet Peas..............39

\section{Miscellaneous}

Farmogerm............49

Fertilizers ............ $\ldots$ 3rd cover

Fumigators and Vaporizers...55

Grasses, General List of . . . . .4

Grass Mixtures .........43-46

Hyacinth Culture.......... I

Hyacinth Glasses............56

Lawn Grass Seed........ 43, 44

Leaf-Rack ............. 54

Miscellaneous Garden Sup-

plies....... .......50-53

Mushrooms, Books on Grow-

ing................... 42

Fungus...............55

Sprayers............... 54

Syringes............

Thermometers, Mushroom or

Hotbed. .

Truck..................

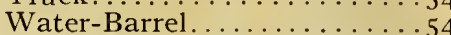

Mushroom Spawn.........42

Vegetable Seeds for Autumn Planting

Beans................. .

Beets................

Carrots................4I

Cauliflower.............4

Cucumber.

Radish

Spinach . .

Tomato

\section{Special Window-Garden Collection of Hyacinths}

We have selected six of the best varieties listed on page 13 which are especially adapted for window-garden culture: Pink, Gigantea; Red, Robert Steiger; White, L'Innocence; Light Blue, Regulus; Dark Blue, Marie; Yellow, Ida.

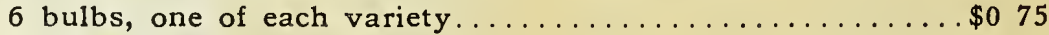

18 bulbs, three of each variety................. 200

36 bulbs, six of each variety................. 50

\section{Hyacinth Glasses}

Hyacinths can be easily and successfully grown in water, giving good spikes of bloom. Single varieties are generally used. Cannot be sent by mail.

Belgian or Tye Shapes. In 5 shades-Crystal, Blue, Green, Amber and Amethyst, Belgian shape, 20 cts. each, $\$ 2$ per doz. Tye shape, 25 cts. each, $\$ 2.50$ per doz.

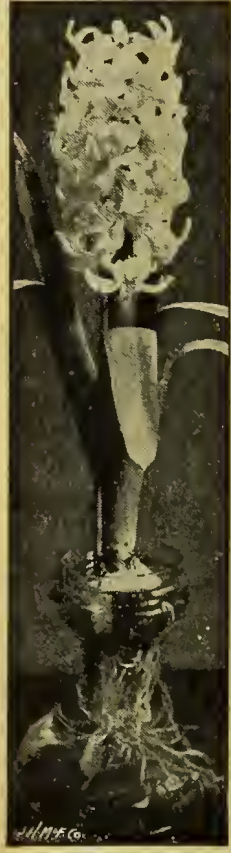

Belgian 


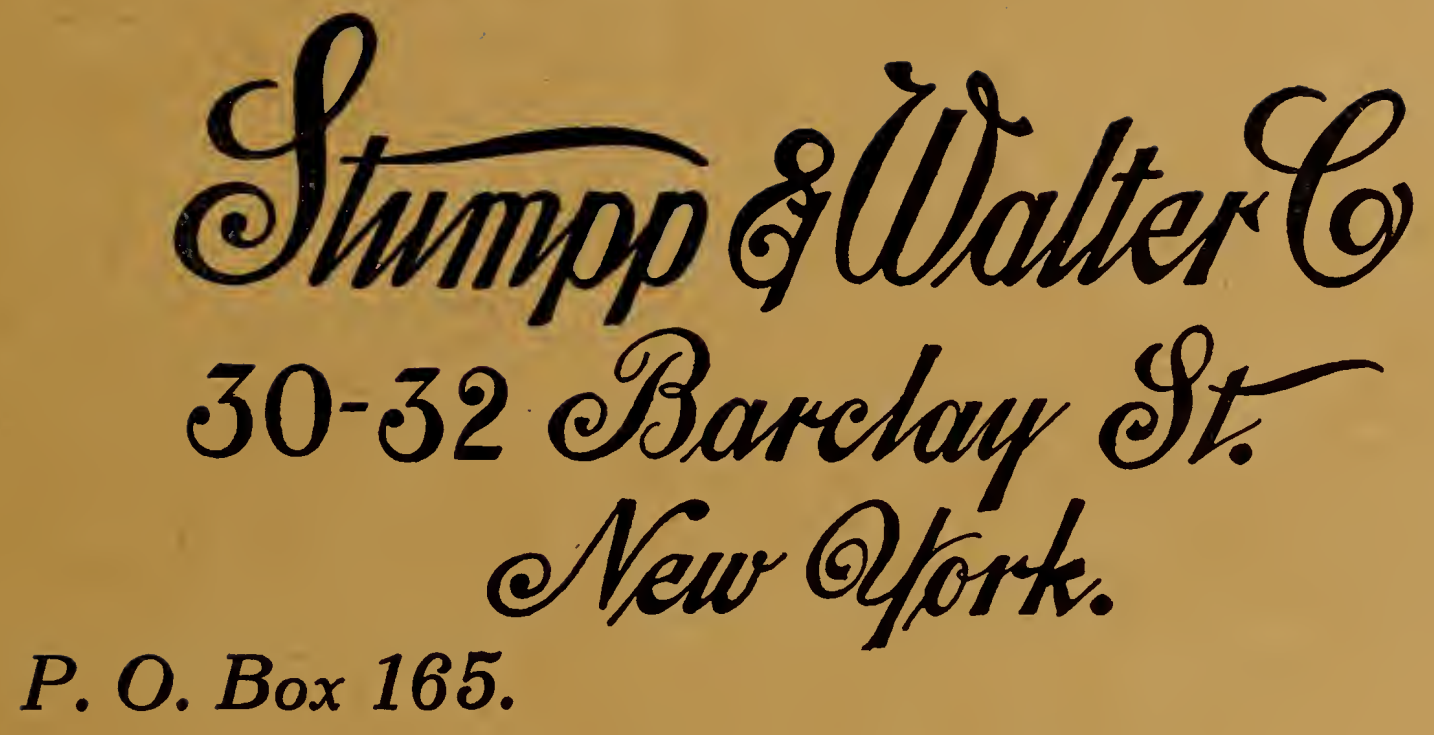




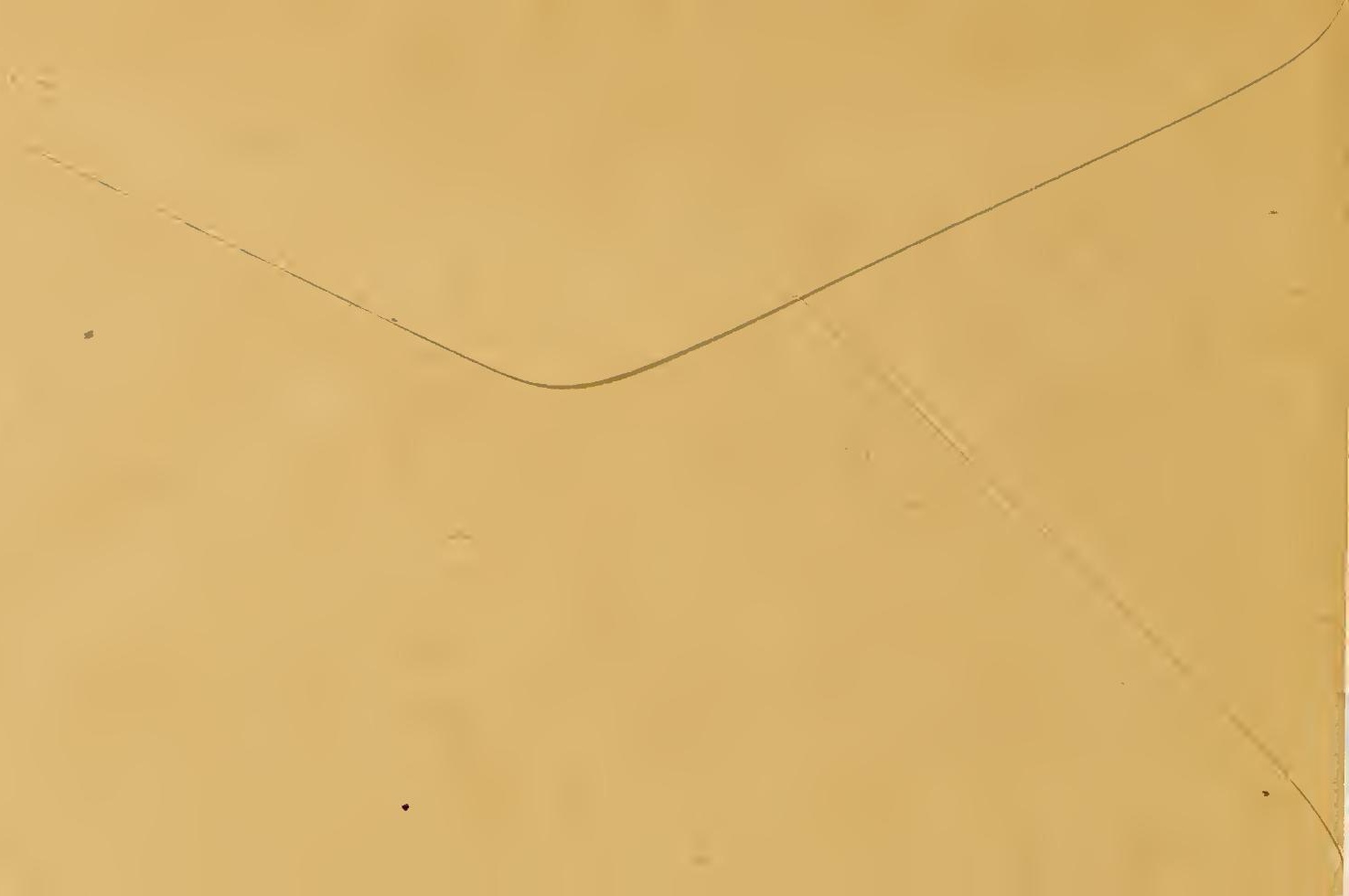


IF the birds should suddenly perish, there would not be a leaf, a blade of grass, or any green thing left upon the earth within a few yearsit would be uninhabitable.

\section{Bring Back The Birds}

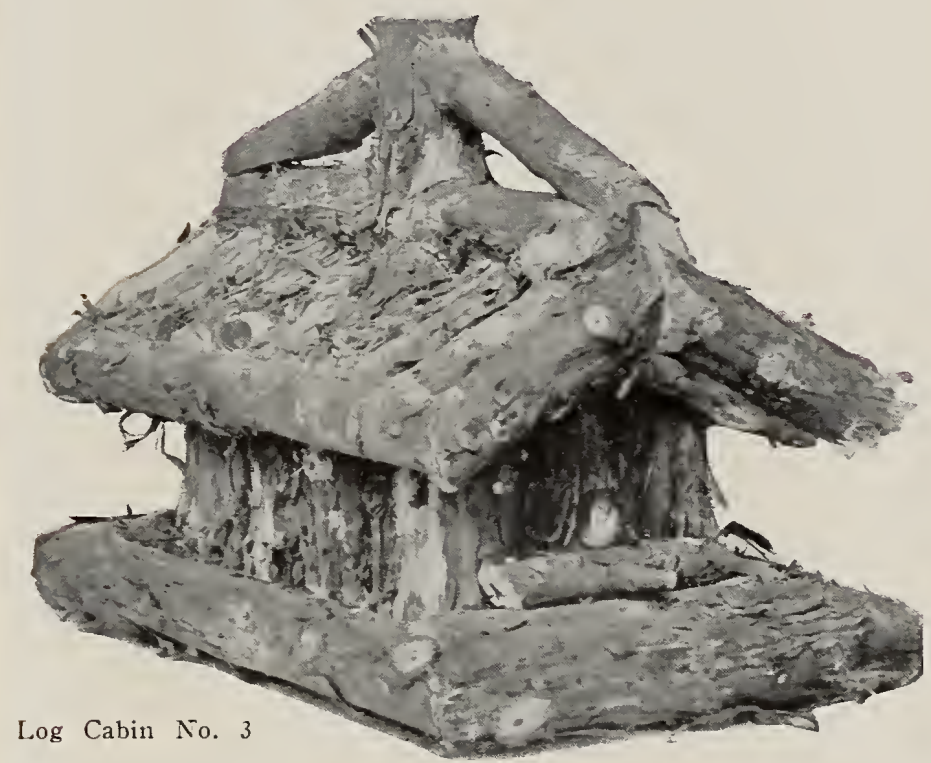

STUMPP \& WALTER CO. 30 \& 32 Barclay Street, New York City, U. S. A. 
What Birds Do For Us

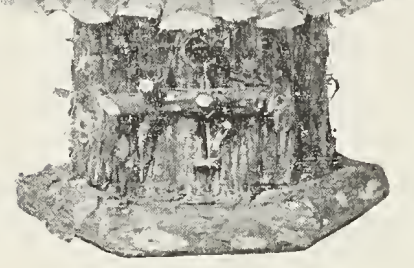

YOU cannot encourage more delightful neighbors th a $n$ birds. G o od spirits are contagious: every one feels better for having a neighbor aîways in good humor. Most birds are irrepressibly cheerful. You may hear their merry cheer almost every month in the year, in fair weather or foul, and some of them have a hundred different melodies in their repertoire.

If you want some jolly little friends, invite the birds to live with you year after year by putting up small one, two and four-family rustic houses in the trees, on the grape arbor on barns and out-houses or on poles. Many birds would be of even greater service than they are if they received just a little encouragement to make their homes nearer ours. They could save many more millions of dollars' worth of crops for the farmers than they do if they were properly protected while rearing their ever hungry families.

The birds will come and go. and quite unconsciously we will associate them with many of our happiest hours as long as we live, for a colony of birds circling about a house gives it a delightful homelike air as we listen to their rippling, musical laughter and their soft. sweet conversation with one another.

Interest in the songs and merry chatter of the birds trains the ear quite unconsciously, and an int e $11 \mathrm{ig}$ e $\mathrm{nt}$ listener soon becomes acq u a in t e d with the little winged

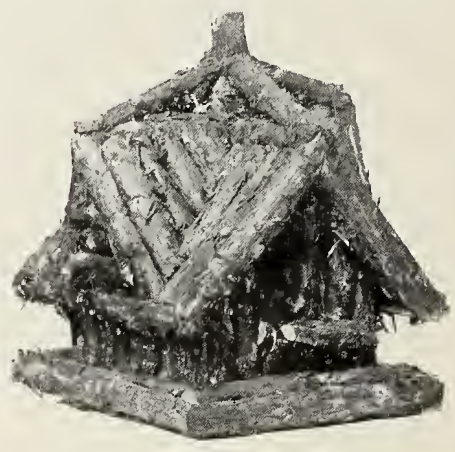

Log Cabin No. 5- $\$ 5.00$ creatures about him, hears every 
sound, and puzzles out its meaning with a cleverness that amazes those who hear not. Nature, the best teacher of us all, trains the child eyes, through study of the birds, to quickness and precision, which are the first requisites for all intelligent observation in every field of knowledge.

Friendship of birds is well worth cultivating, for they have a keen appetite for the many pests of the garden and orchard-moths, grasshoppers, beetles, caterpillars, spiders, flies and other insects. Yet many people, ignorantly, abuse them. Because they have the good taste to like strawberries and cherries as well as we do, are they to be condemned on that account? If they kill insects for us every hour in the day from April to October, do you not think they are cirtitled to a little fruit in June? Even the birds ought to have a square deal.

If one little song bircl eats fonr hundred and forty-four eges of the apple tree moth on Monday, three hundred and thirty-three eggs of the canker worm on Tuesday and seven hundred and seventy-five miscellaneous grubs, larva and insect eggs on Wednesday a n d Thursday, how long will it take a f 1 o c k of twenty - two birds to rid an orchard of e very un -

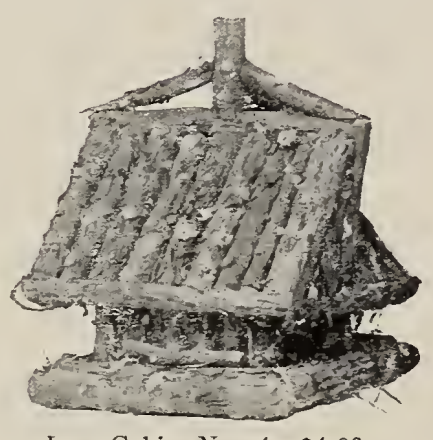

I.og Cabin No. $4-\$ 4.00$ speakable pest?

Is it not a pity for any such would-be tenants to pass by our homes because they cannot find a house to live in? That birds are glad of comfortable homes is shown by their courage in building among the vines or under the shelter of our piazzas. Robins e s p e c i a 11 y need a roof over their heads, and should they not have it, instead of foolishly building their nests on exposed limbs of trees where the first heavy rain is likely to wash them awav? 
Two, three and four broods of birds may be raised in a single house, and as insects are their most approved baby food, you can readily see how much it is to your interest to set up nurseries near your home for these happy, useful and cheerful little companions.

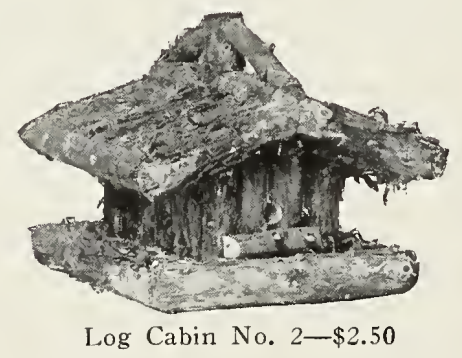

STUMPP \& WALTER CO. 30 \& 32 Barclay Street, New York City, U. S. A.

\section{Homes for the Birds}

Made in many different sizes and of various designs to suit the architecture of your home and sold at prices that will appeal to all.

Log Cabin No. 1 (One Family)

$10 \mathrm{in.}$ wide, $10 \mathrm{in}$. high, $10 \mathrm{in}$. deep

Price, $\$ 1.50$

Log Cabin No. 2

$10 \mathrm{in.}$ wide, $12 \mathrm{in.} \mathrm{high,} 14 \mathrm{in}$. deep

Price, $\$ 2.50$

Log Cabin No. 3

14 in. wide, 12 in. high, 17 in. deep

Price, $\$ 3.50$

Log Cabin No. 4

Colonial Style (Two Family)

14 in. wide, 17 in. high, 16 in. deep

Price, $\$ 4.00$

Log Cabin No. 5

(Four Family)

14 in. wide, 18 in. high, 19 in. deep

Price, $\$ 5.00$

Log Cabin No. 6

$12 \mathrm{in.}$ wide, $14 \mathrm{in}$. high, 19 in. deep Price $\$ 3.50$

Any of the above can be shipped promptly upon receipt of order.

Copyright 1912 by Stumnp \& Walter Co. 
Bulbs, Seeds

Plants, Poultry Supplies Fertilizers

Implements, Etc.

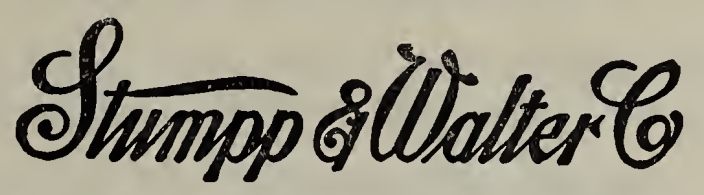

Our New Address After Sept. 1 30-32 Barclay St. NEW YORK

TERMS. While we exercise the greatest care to have all seeds pure and reliable and all Bulbs and Plants true to name and of best quality, we

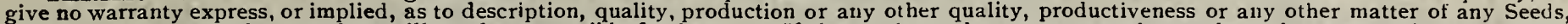

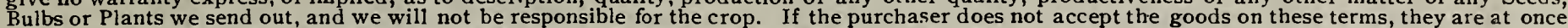
to be returned. All claims must be made within 5 days after receipt of goods.

\section{Name}

Street or Box No.

Date

Town

AMOUNT ENCLOSED

\section{County}

State

$\$$ 


\section{OUR LIST CONTAINS THE VERY BEST AND MOST MODERN KINDS WE CAN QUOTE SPECIAL PRICES ON CAR-LOAD QUANTITIES}

\section{S. \& W. Co.'s Bone Fertilizers}

No. 1 Bone Dust for Quick Acting. A fine ground bone of the best quality that is immediately available. As a top50 cts., 25 lbs. $\$ 1$, 50 lbs. $\$ 1.75$, Ioo lbs. $\$ 3$, ton $\$ 50$.

No. 2 Bone Dust for General Use. A bone dust about pinhead size with a fair percentage of bone flour. Excellent for and rose-growers for top-dressing and for mixing with soil. $5 \mathrm{lbs}$. $25 \mathrm{cts}$., Io lbs. 40 cts., $25 \mathrm{lbs} .75 \mathrm{cts}$., 50 o lbs. $\$$ I. 40 o, Ioo lbs. $\$ 2.50$, ton $\$ 40$. No. 3 Crushed Bone for Vines and Trees. Largely used for vine borders, trees and shrubs. About the size of a bean. $\$ 1.75$, Ioo lbs. $\$ 3$, ton $\$ 45$.

S. \& W. Co.'s Charcoal. Excellent for mixing with vine borders. Three sizes, No Lumps, 3 to 4 inches. Per bag, 50 lbs., $\$ 1.25$, any size.

S. \& W. Co.'s Potato Manure. This brand is our Manure. leader, and is manufactured from a bone and meat basis, and is high in analysis and a strictly high-grade fertilizer. It is a brand that has given universal satisfaction for all root crops, and it is unequaled for potatoes, gardening or truck farming, 50 lbs, $\$ 1.75$, I00 lbs. $\$ 3,500$ lbs. $\$ 12$, I,000 lbs. $\$ 22.50$, ton $\$ 42$.

\section{GENERAL LIST OF FERTILIZERS}

ASHES, CANADA HARDWOOD. Quantity required: Apply I to 2 tons per acre, as one heavy application will help much more than the same quantity would applied in fractions. Bbl. of about 200 lbs. $\$ 3$, ton of 2,000 lbs., in bbls., $\$ 24$; by car, $\$ 22$ per ton.

BON ARBOR. A complete plant-food. High in nitrogen, potash and phosphoric acid. $1 / 2-1 \mathrm{~b}$. package, makes $\mathrm{I} 5$ gallons liquid, $25 \mathrm{c}$., I-lb. package 50 cts., 5-1b. package $\$ 1.80$. Circular on application.

"BONORA," "NATURE'S PLANT-FOOD." 5 lbs. making I 40 gallons, $\$ 2.50,1 / 4-1 b$. package 25 cts., I-lb. package $50 \mathrm{cts}$. Circular and further information on application.

BOWKER'S AMMONIATED FOOD FOR FLOWERS. Made especially for plants grown in the conservatory, house or garden; clean, free from offensive odor. Full directions with each package Small size, I 5 cts., large size $25 \mathrm{cts}$; ; by mail, $20 \mathrm{cts}$. and $30 \mathrm{cts}$.

CLAY'S CELEBRATED FERTILIZER. In bags, I cwt. (I I 2 lbs.) $\$ 7,1 / 2$ cwt. (56 lbs.) $\$ 4,1 / 4$ cwt. (28 lbs.) $\$ 2.25,1 / 8$ cwt. (I 4 lbs.) $\$ I_{.25}$.

COW or CATTLE MANURE (Shredded). One sack of this is equal to one cart-load of fresh cow manure, is convenient to handle, making it possible for everyone to get this usually scarce article at all times. In Ioo-lb. sacks only. I00 lbs. $\$ 2,500 \mathrm{lbs} . \$ 9, \mathrm{I}, 000$ lbs. $\$ 16$, ton $\$ 30$

DRIED BLOOD. Fourteen per cent ammonia. Excellent for Carnations. Io lbs. 75 cts., 50 lbs. $\$ 3$, I0o lbs. $\$ 5$.

EMERALD LAWN DRESSING. A clean, portable and convenient lawn dressing, which we have found to be never-failing in inducing a rapid and rich green growth. It should be sown broadcast in the spring or fall, though it can be put on during the summer without injury or danger of burning the grass, and a remarkable improvement will soon be observed. It is in every way more desirable than manure, The use of "Emerald Lawn Dressing" entirely does away with the old practice of top-dressing lawns with stable manure,. Quantity required: A Io-lb. package is sufficient to go over an area of 300 square feet, or for forming a new lawn, from I, Ooo to I, 500 lbs. per acre, or a smaller quantity for renovating an old one. 5 lbs. 25 cts., Io lbs. 45 cts., 25 lbs. $\$$ I, 50 lbs. $\$$ I. 75, I 00 lbs. $\$ 3,500$ lbs. $\$ 12.50,2,000$ lbs. (ton) $\$ 45$.

FARMOGERM. High-bred nitrogen-fixing bacteria. Farmogerm is put up in bottles in the following sizes: Garden size, containing material to treat the seeds for one-sixth acre of land, 50 cts.; acresize, containing material to treat the seeds for one acre, $\$ 2$; fiveacre size, containing material to treat the seeds for five acres of land, \$9. For the following crops in acre sizes: Red Clover, Mammoth Clover, Crimson Clover, White Clover, Burr Clover, Sweet Clover, Alsike, Alfalfa, Berseem, Peanuts, Vetch, Lupins, Garden Beans, Garden Peas, Sweet Peas, Cowpeas, Canadian Field Peas, Soy Beans, and all other legumes. In garden size for Peas, Beans and Sweet Peas; also a mixed culture good for all three. In ordering, state what crop you wish to plant, quantity wanted, and ask for book on the Farmogerm Method.

HORN SHAVINGS. Used principally for mixing in potting soil, is rich in ammonia; especially valuable in Chrysanthemum-growing. Lb. Io cts., 5 lbs. 40 cts., 25 lbs. $\$ 1.75,50$ lbs. $\$ 2.75$, I0o lbs. $\$ 5$
S. \& W. Co's General Garden Fertilizer. This fertilizer is for general garden work for vegetables, flowers and fruits. Io lbs. sufficient for space $15 \times 15.500 \mathrm{lbs}$. to the acre. $5 \mathrm{lbs}$. 25 cts., Io lbs. 45 cts., 25 lbs. $\$$ I, 50 lbs. $\$$ I.75, Ioo lbs. $\$ 3$, ton $\$ 45$.

S. \& W. Co.'s Corn Fertilizer. This is a brand ers prefer to use that have sufficient quantities of stable manure for broadcast application, using this brand in the hill or drill. We have many interesting testimonials as to its quality for growing splendid crops of corn. 5olbs. $\$ 1.75$, I00 lbs. $\$ 3,500 \mathrm{lbs}$. $\$ 1$ I, I, 00olbs. $\$ 20$, ton $\$ 37$.

ICHTHEMIC GUANO. One of the best well-balanced plant-foods on the market, fulfilling all the requirements of plants and flowers, fruit and vegetables. Imported in original bags of II 2 lbs. each 28 lbs. $\$ 2.50,56$ lbs. $\$ 4$, I I 2 lbs. $\$ 7$.

R. R. AGRICULTURAL LIME. This lime is specially prepared for use on the soil, and is a combination of calcium hydrate and calcium carbonate, finely pulverized. Lime is essential, as a plantfood and as a corrective for improper condition of the soil. It also acts as a neutralizer for acid soils. Quantity required: Heavy soils, 2,000 to 6,000 lbs. per acre. Light sandy soils, I, 000 to 3,000 lbs. per acre, according to their apparent need. Price, per Ioo-1b. bag, $\$$ I.25, $500 \mathrm{lbs}$. $\$ 5$, ton $\$$ I 4 . In lots of 3 tons or over, \$I 2.50 per ton, car-load lots $\$ 9$ per ton, f. o. b. New York.

MURIATE OF POTASH. A form of potash salts to be used with bone meal, bone and blood, or farm manures, on fruits, celery, asparagus, corn, oats, turnips, cucumbers, grapes, carrots, onions, peas, clover and beans. Must not be used on hops, potatoes, tobacco, flax, sugar beets, cabbage or caulifiower. 50 to $400 \mathrm{lbs}$ per acre. 5 lbs. $30 \mathrm{cts}$., Io lbs. $50 \mathrm{cts} ., 25$ lbs. \$I, 50 lbs. $\$$ I. 85,100 lbs. $\$ 3.50,200$ lbs. $\$ 6.50,500$ lbs. $\$$ I 5.50 . Write for prices on ton lots.

NITRATE OF SODA. Quantity required: Being extremely soluble, it is usually applied after the plants are above ground. Ioo to 500 lbs. per acre. 5 -lb. package, 40 cts., I0-1b. package $70 \mathrm{cts}$. 25-lb. bag $\$$ I.5O, 50-1b. bag $\$ 2.50$, IOo lbs. $\$ 4.50$.

SALT. For agricultural purposes, asparagus beds and putting on walks and roads to kill weeds. Apply 600 to 800 lbs. per acre in early spring. Io lbs. 20 cts., 25 lbs. 30 cts., 50 lbs. 55 cts., I 00 lbs. \$I, 200 lbs. \$I.50, ton \$IO.

SULPHATE OF AMMONIA. Used for its nitrogen. A very desirable fertilizer for all plants in which a large leaf development or rapid growth is desired. Use I pound to 50 square feet of ground or bench, or a tablespoonful to a bushel of soil, or 3 gallons of water. I lb. 25 c., 5 lbs. 60c., Io lbs. \$I.Io, 25 lbs. \$I.75, IOO lbs. \$6.50.

PURE PULVERIZED SHEEP MANURE. A pure, natural nutritious manure. Immediate and lasting in effect. Excellent for mixing witli the soil for greenlouse plants. In the vegetable garden it promotes a rapid, steady growth until maturity. It makes a rich liquid manure. Quantity required: For garden and field crops, I to 2 tons per acre; one-half before plowing, the balance before harrowing. For top-dressing grass, use I ton per acre, applied in fall or early spring. I00-lb. bag $\$ 2$, ton of 2,000 lbs. $\$ 30$. In packages of 2 lbs. I5 cts., 5 lbs. 25 cts., Io lbs. 40 cts.

SCOTCE SOOT. Genuine imported. One of the best fertilizers for stimulating healthy growth of dark green foliage, and it will free the soil of slugs, grubs and cut-worms. Io lbs. $60 \mathrm{cts}$., 50 lbs. $\$ 2$. Ioo lbs. \$4.

THOMSON'S VINE, PLANT AND VEGETABLE MANURE. 28 lbs. $\$$ I. 75,56 lbs. $\$ 3.50$, II 2 lbs. $\$ 6.75$.

THOMSON'S SPECIAL CHRYSANTHEMUIM AND TOP. DRESSING MANURE. An excellent stimulant for top-dressing Chrysanthemums and all fiowering plants. 7-1b, bag, $\$ 1.50$, I4-lb. bag $\$ 2.50,28-1 \mathrm{~b}$. bag $\$ 4,56-1 \mathrm{i}$. bag $\$ 7$. 
